\title{
SULFATE RETENTION IN HIGH LEVEL WASTE (HLW) SLUDGE BATCH 4 (SB4) GLASSES: A PRELIMINARY ASSESSMENT
}

K.M. Fox

T.B. Edwards

D.K. Peeler

December 2006

Process Science and Engineering Section Savannah River National Laboratory Aiken, SC 29808

Prepared for the U.S. Department of Energy Under Contract Number DEAC09-96SR18500

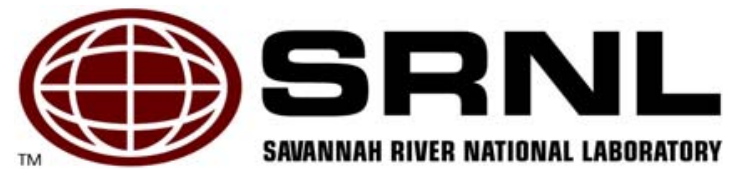




\section{DISCLAIMER}

This report was prepared by Washington Savannah River Company (WSRC) for the United States Department of Energy under Contract No. DE-AC09-96SR18500 and is an account of work performed under that contract. Neither the United States Department of Energy, nor WSRC, nor any of their employees makes any warranty, expressed or implied, or assumes any legal liability or responsibility for the accuracy, completeness, or usefulness, of any information, apparatus, or product or process disclosed herein or represents that its use will not infringe privately owned rights. Reference herein to any specific commercial product, process, or service by trademark, name, manufacturer or otherwise does not necessarily constitute or imply endorsement, recommendation, or favoring of same by WSRC or by the United States Government or any agency thereof. The views and opinions of the authors expressed herein do not necessarily state or reflect those of the United States Government or any agency thereof.

\section{Printed in the United States of America \\ Prepared For \\ U.S. Department of Energy}

The Savannah River National Laboratory is operated for the U.S. Department of Energy by Washington Savannah River Company. 
Keywords: high level waste, glass, sulfur, solubility

Retention: permanent

\section{SULFATE RETENTION IN HIGH LEVEL WASTE (HLW) SLUDGE BATCH 4 (SB4) GLASSES: A PRELIMINARY ASSESSMENT}

K.M. Fox

T.B. Edwards

D.K. Peeler

December 2006

Process Science and Engineering Section Savannah River National Laboratory Aiken, SC 29808 


\section{REVIEWS AND APPROVALS}

\section{AUTHORS:}

K.M. Fox, Materials Science and Technology Section

Date

T.B. Edwards, Statistical Consulting Section

Date

D.K. Peeler, Process Science and Engineering Section

Date

TECHNICAL REVIEWER:

M.E. Smith, Process Science and Engineering Section

Date

\section{APPROVERS:}

R.E. Edwards, Manager, Process Science and Engineering Section

Date

C.C. Herman, Manager, Process Engineering Technology Group

Date

J.E. Occhipinti, Manager, Process Cognizant Engineering

Date

Waste Solidification Engineering 
WSRC-STI-2006-00038

Revision 0

\section{EXECUTIVE SUMMARY}

Early projections of the Sludge Batch 4 (SB4) composition predicted relatively high concentrations of alumina $\left(\mathrm{Al}_{2} \mathrm{O}_{3}, 23.5 \mathrm{wt} \%\right)$ and sulfate $\left(\mathrm{SO}_{4}{ }^{2-}, 1.2 \mathrm{wt} \%\right)$ in the sludge. A high concentration of $\mathrm{Al}_{2} \mathrm{O}_{3}$ in the sludge, combined with $\mathrm{Na}_{2} \mathrm{O}$ additions in the frit, raises the potential for nepheline crystallization in the glass. However, strategic frit development efforts at the Savannah River National Laboratory (SRNL) have shown that frits containing a relatively high concentration of $\mathrm{B}_{2} \mathrm{O}_{3}$ can both suppress nepheline crystallization and improve melt rates. A high sulfate concentration is a concern to the DWPF as it can lead to the formation of sulfate inclusions in the glass and/or the formation of a molten, sulfate-rich phase atop the melt pool. To avoid these issues, a sulfate concentration limit of $0.4 \mathrm{wt} \% \mathrm{SO}_{4}{ }^{2-}$ in glass was originally set in the Product Composition Control System (PCCS) used at DWPF. It was later shown that this limit could be increased to $0.6 \mathrm{wt} \% \mathrm{SO}_{4}{ }^{2-}$ in glass for the Frit 418, Sludge Batch 3 (SB3) system.

Two frits have been evaluated for use with the early projections of SB4. Frit 418, which has been used previously with SB3, has been shown to produce glasses with SB4 that have an acceptable and predictable durability. Frit 503, a high boron concentration frit, has also been shown to produce durable glasses with SB4, and has advantages in melt rate over Frit 418. The applicability of the current 0.6 wt\% sulfate limit to the SB4 / Frit 418 or Frit 503 system, and/or the possibility of increasing the sulfate limit for SB4 are the subjects of this study.

Ten glasses were fabricated in the laboratory using the May 2006 SB4 composition projection and Frits 418 and 503 at 38\% waste loading. The glasses were intentionally spiked to relatively high sulfate concentrations of between 0.6 and $0.8 \mathrm{wt} \%$ in the glass (as compared to the nominal value of $0.49 \mathrm{wt} \%$ ). The glasses were batched from laboratory chemicals and melted following standard SRNL procedures. No sulfur salt layer was visually observed on any of the study glasses after pouring and quenching. The measured compositions of each of the glasses met the target values. The LRM glass standard results indicated that sulfate concentration was measured accurately in this study. Sulfate volatilization occurred in all of the study glasses, as evidenced by measured sulfate concentrations that fell below the targeted values. However, the glasses that targeted the highest sulfate concentrations using either Frit 418 or Frit 503 retained sulfate at concentrations at or above the previous limit of $0.6 \mathrm{wt} \%$ established for SB3 processing. These results imply that this same limit may be extended to SB4 processing. Note however that these results are based on a SB4 composition projection provided in May 2006, and therefore should not be used as the sole technical basis for establishing the sulfate limit. Additional experimental work should be undertaken to verify these results using the most current composition projection for SB4. 


\section{TABLE OF CONTENTS}

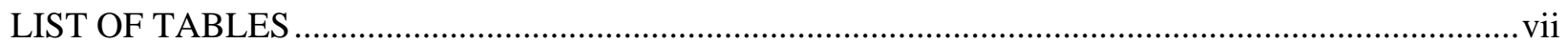

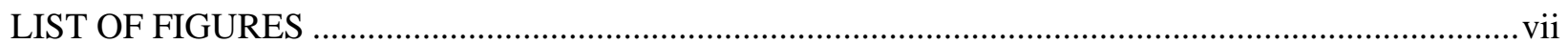

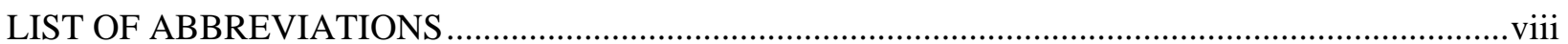

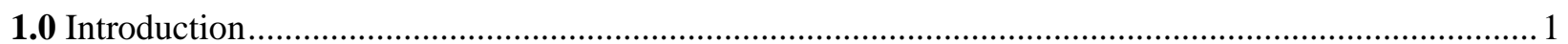

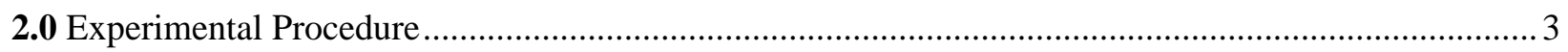

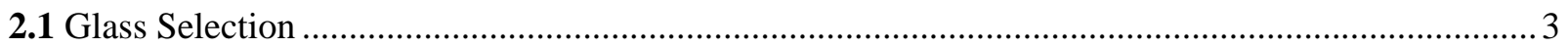

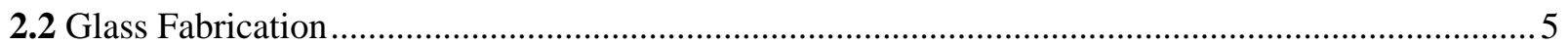

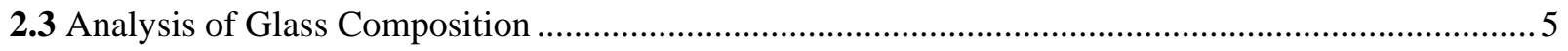

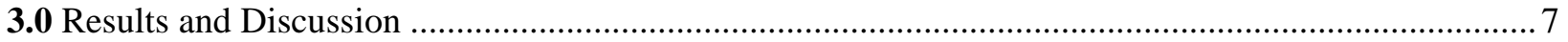

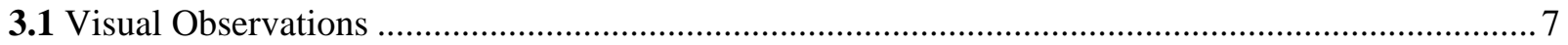

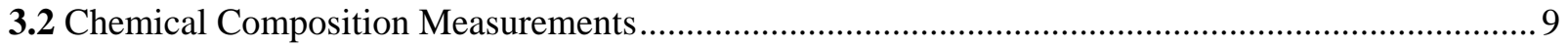

3.2.1 Measurements in Analytical Sequence ..................................................................................... 9

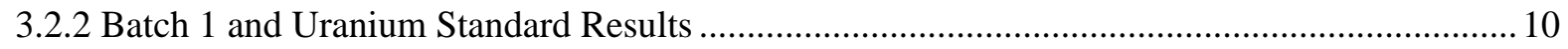

3.2.3 Composition Measurements by Glass Number .......................................................................... 11

3.2.4 Measured versus Targeted Compositions ….............................................................................. 11

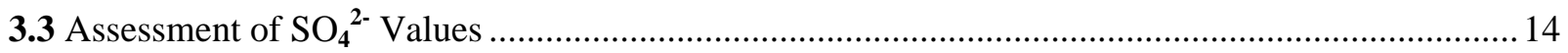

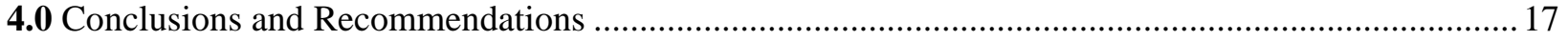

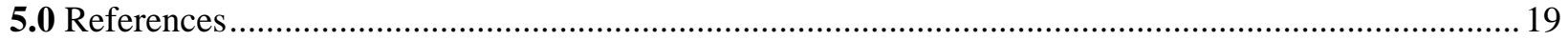

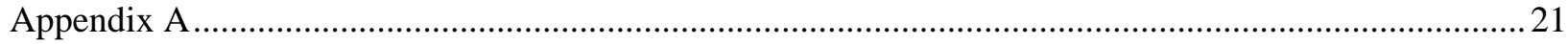

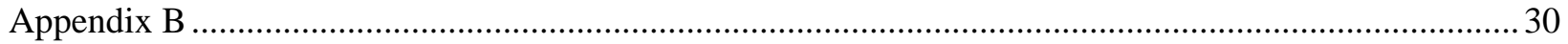




\section{LIST OF TABLES}

Table 2-1. Compositions of Frits Used in the Sulfate Study (in wt\%).................................................... 3

Table 2-2. Target Compositions of the Frit 418 Sulfate Study Glasses (in wt\%)...................................... 4

Table 2-3. Target Compositions of the Frit 503 Sulfate Study Glasses (in wt\%).................................... 5

Table 3-1. Visual Observations for the Sulfate Study Glasses. …............................................................. 8

\section{LIST OF FIGURES}

Figure 3-1. Measured Concentrations for the 6 LRM Samples by Oxide..............................................13

Figure 3-2. $\mathrm{SO}_{4}{ }^{2-}$ Values for Glasses in the Analytical Plan by Glass ID .............................................. 14 


\section{LIST OF ABBREVIATIONS}

$\begin{array}{ll}\text { ANOVA } & \begin{array}{l}\text { ANalysis Of VAriance } \\ \text { ASTM }\end{array} \\ \text { bc } & \begin{array}{l}\text { bias-corrected } \\ \text { DWPF }\end{array} \\ \text { Defense Waste Processing Facility } \\ \text { High Level Waste } \\ \text { ICP-AES } & \text { Inductively Coupled Plasma - Atomic Emission Spectroscopy } \\ \text { LM } & \text { Lithium-Metaborate } \\ \text { LRM } & \text { Low-level waste Reference Material } \\ \text { LWO } & \text { Liquid Waste Operations } \\ \text { PCCS } & \text { Product Composition Control System } \\ \text { PF } & \text { Peroxide Fusion } \\ \text { PSAL } & \text { Process Science Analytical Laboratory } \\ \text { SB3 / SB4 } & \text { Sludge Batch 3 / Sludge Batch 4 } \\ \text { SRNL } & \text { Savannah River National Laboratory } \\ \text { WL } & \text { Waste Loading (weight percent) }\end{array}$


WSRC-STI-2006-00038

Revision 0

\subsection{Introduction}

Early projections of the Sludge Batch 4 (SB4) composition predicted relatively high concentrations of alumina $\left(\mathrm{Al}_{2} \mathrm{O}_{3}\right)$ and sulfate $\left(\mathrm{SO}_{4}{ }^{2-}\right)$ in the sludge. ${ }^{1}$ This raises several issues with regard to frit development for production of a durable, vitrified waste form at the Defense Waste Processing Facility (DWPF).

A high concentration of $\mathrm{Al}_{2} \mathrm{O}_{3}$ in the sludge, combined with relatively high $\mathrm{Na}_{2} \mathrm{O}$ concentrations from the sludge or frit, raises the potential for nepheline crystallization in the glass. Nepheline crystallization can have a strongly negative impact on chemical durability of the glass. However, strategic frit development efforts at the Savannah River National Laboratory (SRNL) have shown that frits containing a relatively high concentration of $\mathrm{B}_{2} \mathrm{O}_{3}$ can both suppress nepheline crystallization and improve melt rates. ${ }^{2-6}$

A high sulfate concentration is a concern to the DWPF as it can lead to the formation of sulfate inclusions in the glass and/or the formation of a molten, sulfate-rich phase atop the melt pool. To avoid these issues, a sulfate concentration limit of $0.4 \mathrm{wt} \% \mathrm{SO}_{4}{ }^{2-}$ in glass was originally set in the Product Composition Control System (PCCS) used at DWPF. ${ }^{7} 8$ It was later shown that this limit could be increased to $0.6 \mathrm{wt} \% \mathrm{SO}_{4}{ }^{2-}$ in glass for the Frit 418 / SB3 system. ${ }^{9}$

Two frits have been evaluated for use with the early projections of SB4. ${ }^{10}$ Frit 418, which has been used previously with Sludge Batch 3 (SB3), has been shown to produce glasses with SB4 that have an acceptable and predictable durability. ${ }^{11}$ Frit 503, a high boron concentration frit, has also been shown to produce durable glasses with SB4, ${ }^{2,12}$ and has advantages in melt rate over Frit $418{ }^{6}$

The applicability of the current sulfate limit to the SB4 / Frit 418 or Frit 503 system, and/or the possibility of increasing the sulfate limit for SB4 are the subjects of this study. It should be noted that the data presented in this report are not sufficient to provide a technical basis for DWPF operation but do provide valuable insight into the compositional effects of $\mathrm{SO}_{4}{ }^{2-}$ solubility for the compositional region of interest as defined by SB4.

Glasses based on both Frit 418 and Frit 503 with SB4 at 38\% waste loading (WL) were made with spiked $\mathrm{SO}_{4}{ }^{2-}$ concentrations of up to $0.8 \mathrm{wt} \%$. Chemical composition measurements along with a thorough statistical analysis of the errors associated with these measurements were used to evaluate the amount of sulfate retained in the study glasses after melting and quenching.

It should be noted that more recent projections of the SB4 composition ${ }^{13}$ have indicated reduced concentrations of $\mathrm{SO}_{4}{ }^{2-}$, to a point where sulfate solubility is not of major concern for processing of this sludge batch. However, the data presented here remain relevant to SB4 processing (i.e., can be used to establish the technical basis for the SB4 $\mathrm{SO}_{4}{ }^{2-}$ limit once a frit recommendation is made), and will aid in frit development for future sludge batches.

This work was initiated by a Technical Task Request ${ }^{14}$ and is covered by a Technical Task and Quality Assurance Plan. ${ }^{15}$ 
WSRC-STI-2006-00038

Revision 0

This page intentionally left blank. 
WSRC-STI-2006-00038

Revision 0

\subsection{Experimental Procedure}

\subsection{Glass Selection}

Ten glass compositions were selected for this study. A Blend 1, $0.96 \mathrm{M} \mathrm{Na}^{+}$sludge composition was used in defining the glasses, as this was the most recent composition projection for SB4 available at the time these experiments were undertaken. ${ }^{\mathrm{a}}$ The nominal $\mathrm{SO}_{4}{ }^{2-}$ concentration in this projection was $1.3 \mathrm{wt} \%$. A high $\mathrm{B}_{2} \mathrm{O}_{3}$ frit (Frit 503) was chosen for this study based on preliminary melt rate experiments ${ }^{6}$ and the assessments associated with projected operating windows. ${ }^{16}$ The melt rate experiments showed a significant improvement in melt rate for Frit 503 / SB4 glasses compared with earlier, lower $\mathrm{B}_{2} \mathrm{O}_{3}$ frits. ${ }^{6}$ A second frit, Frit 418, was also included in this study, as SRNL has identified this frit as being viable for use during the transition from SB3 to SB4 at DWPF. ${ }^{10}$ The compositions of both frits are given in Table 2-1.

Table 2-1. Compositions of Frits Used in the Sulfate Study (in wt\%).

\begin{tabular}{|c|c|c|c|c||}
\hline Frit ID & $\mathbf{B}_{\mathbf{2}} \mathbf{O}_{3}$ & $\mathbf{L i}_{\mathbf{2}} \mathbf{O}$ & $\mathbf{N a}_{\mathbf{2}} \mathbf{O}$ & $\mathbf{S i O}_{\mathbf{2}}$ \\
\hline 418 & 8 & 8 & 8 & 76 \\
\hline 503 & 14 & 8 & 4 & 74 \\
\hline
\end{tabular}

The frits and sludge were combined at a waste loading of $38 \mathrm{wt} \%$, as this $\mathrm{WL}$ is seen as a likely upper bound for DWPF processing of SB4. At $38 \mathrm{wt} \% \mathrm{WL}$, the nominal $\mathrm{SO}_{4}{ }^{2-}$ concentration for SB4 glass is 0.49 wt \%, using either Frit 418 or Frit 503. These compositions were then adjusted (or spiked) with increased $\mathrm{SO}_{4}{ }^{2-}$ concentrations with the intent of measuring the amount of $\mathrm{SO}_{4}{ }^{2-}$ that can be retained in the Frit 418 and Frit 503 / SB4 systems. Targeted sulfate concentrations in the glass were spiked to $0.60,0.65,0.70,0.75$ and $0.80 \mathrm{wt} \%$, and the remaining glass components were renormalized.

The target compositions of the five Frit 418 / SB4 glasses are listed in Table 2-2. The target compositions for the five Frit 503 / SB4 glasses are listed in Table 2-3.

\footnotetext{
a Projected compositions provided by $\mathrm{H}$. Shah on 5/9/06. For more details, see pages 28 - 33 of WSRC-NB-2006-00017.
} 
Table 2-2. Target Compositions of the Frit 418 Sulfate Study Glasses (in wt\%).

\begin{tabular}{|c|c|c|c|c|c|}
\hline Glass IDs & SB4SULFA-01 & SB4SULFA-02 & SB4SULFA-03 & SB4SULFA-04 & SB4SULFA-05 \\
\hline $\mathrm{Al}_{2} \mathrm{O}_{3}$ & 8.93 & 8.92 & 8.92 & 8.91 & 8.91 \\
\hline $\mathrm{B}_{2} \mathrm{O}_{3}$ & 4.95 & 4.95 & 4.95 & 4.95 & 4.94 \\
\hline $\mathrm{BaO}$ & 0.05 & 0.05 & 0.05 & 0.05 & 0.05 \\
\hline $\mathrm{CaO}$ & 0.90 & 0.90 & 0.90 & 0.90 & 0.90 \\
\hline $\mathrm{Ce}_{2} \mathrm{O}_{3}$ & 0.06 & 0.06 & 0.06 & 0.06 & 0.06 \\
\hline $\mathrm{Cr}_{2} \mathrm{O}_{3}$ & 0.08 & 0.08 & 0.08 & 0.08 & 0.08 \\
\hline $\mathrm{CuO}$ & 0.02 & 0.02 & 0.02 & 0.02 & 0.02 \\
\hline $\mathrm{Fe}_{2} \mathrm{O}_{3}$ & 10.04 & 10.03 & 10.03 & 10.02 & 10.02 \\
\hline $\mathrm{K}_{2} \mathrm{O}$ & 0.12 & 0.12 & 0.12 & 0.12 & 0.12 \\
\hline $\mathrm{La}_{2} \mathrm{O}_{3}$ & 0.04 & 0.04 & 0.04 & 0.04 & 0.04 \\
\hline $\mathrm{Li}_{2} \mathrm{O}$ & 4.95 & 4.95 & 4.95 & 4.95 & 4.94 \\
\hline $\mathrm{MgO}$ & 0.96 & 0.96 & 0.96 & 0.96 & 0.96 \\
\hline $\mathrm{MnO}$ & 2.07 & 2.07 & 2.07 & 2.06 & 2.06 \\
\hline $\mathrm{Na}_{2} \mathrm{O}$ & 13.97 & 13.96 & 13.96 & 13.95 & 13.94 \\
\hline $\mathrm{NiO}$ & 0.59 & 0.59 & 0.59 & 0.59 & 0.59 \\
\hline $\mathrm{PbO}$ & 0.04 & 0.04 & 0.04 & 0.04 & 0.04 \\
\hline $\mathrm{SO}_{4}{ }^{2-}$ & 0.60 & 0.65 & 0.70 & 0.75 & 0.80 \\
\hline $\mathrm{SiO}_{2}$ & 48.56 & 48.54 & 48.52 & 48.49 & 48.47 \\
\hline $\mathrm{ThO}_{2}$ & 0.02 & 0.02 & 0.02 & 0.02 & 0.02 \\
\hline $\mathrm{TiO}_{2}$ & 0.01 & 0.01 & 0.01 & 0.01 & 0.01 \\
\hline $\mathrm{U}_{3} \mathrm{O}_{8}$ & 2.91 & 2.91 & 2.91 & 2.91 & 2.91 \\
\hline $\mathrm{ZnO}$ & 0.04 & 0.04 & 0.04 & 0.04 & 0.04 \\
\hline $\mathrm{ZrO}_{2}$ & 0.09 & 0.09 & 0.09 & 0.09 & 0.09 \\
\hline Sum & 100.00 & 100.00 & 100.00 & 100.00 & 100.00 \\
\hline
\end{tabular}


WSRC-STI-2006-00038

Revision 0

Table 2-3. Target Compositions of the Frit 503 Sulfate Study Glasses (in wt\%).

\begin{tabular}{|c|c|c|c|c|c|}
\hline Glass IDs & SB4SULFA-06 & SB4SULFA-07 & SB4SULFA-08 & SB4SULFA-09 & SB4SULFA-10 \\
\hline $\mathrm{Al}_{2} \mathrm{O}_{3}$ & 8.93 & 8.92 & 8.92 & 8.91 & 8.91 \\
\hline $\mathrm{B}_{2} \mathrm{O}_{3}$ & 8.67 & 8.67 & 8.66 & 8.66 & 8.65 \\
\hline $\mathrm{BaO}$ & 0.05 & 0.05 & 0.05 & 0.05 & 0.05 \\
\hline $\mathrm{CaO}$ & 0.90 & 0.90 & 0.90 & 0.90 & 0.90 \\
\hline $\mathrm{Ce}_{2} \mathrm{O}_{3}$ & 0.06 & 0.06 & 0.06 & 0.06 & 0.06 \\
\hline $\mathrm{Cr}_{2} \mathrm{O}_{3}$ & 0.08 & 0.08 & 0.08 & 0.08 & 0.08 \\
\hline $\mathrm{CuO}$ & 0.02 & 0.02 & 0.02 & 0.02 & 0.02 \\
\hline $\mathrm{Fe}_{2} \mathrm{O}_{3}$ & 10.04 & 10.03 & 10.03 & 10.02 & 10.02 \\
\hline $\mathrm{K}_{2} \mathrm{O}$ & 0.12 & 0.12 & 0.12 & 0.12 & 0.12 \\
\hline $\mathrm{La}_{2} \mathrm{O}_{3}$ & 0.04 & 0.04 & 0.04 & 0.04 & 0.04 \\
\hline $\mathrm{Li}_{2} \mathrm{O}$ & 4.95 & 4.95 & 4.95 & 4.95 & 4.94 \\
\hline $\mathrm{MgO}$ & 0.96 & 0.96 & 0.96 & 0.96 & 0.96 \\
\hline $\mathrm{MnO}$ & 2.07 & 2.07 & 2.07 & 2.06 & 2.06 \\
\hline $\mathrm{Na}_{2} \mathrm{O}$ & 11.49 & 11.49 & 11.48 & 11.48 & 11.47 \\
\hline $\mathrm{NiO}$ & 0.59 & 0.59 & 0.59 & 0.59 & 0.59 \\
\hline $\mathrm{PbO}$ & 0.04 & 0.04 & 0.04 & 0.04 & 0.04 \\
\hline $\mathrm{SO}_{4}{ }^{2-}$ & 0.60 & 0.65 & 0.70 & 0.75 & 0.80 \\
\hline $\mathrm{SiO}_{2}$ & 47.33 & 47.30 & 47.28 & 47.25 & 47.23 \\
\hline $\mathrm{ThO}_{2}$ & 0.02 & 0.02 & 0.02 & 0.02 & 0.02 \\
\hline $\mathrm{TiO}_{2}$ & 0.01 & 0.01 & 0.01 & 0.01 & 0.01 \\
\hline $\mathrm{U}_{3} \mathrm{O}_{8}$ & 2.91 & 2.91 & 2.91 & 2.91 & 2.91 \\
\hline $\mathrm{ZnO}$ & 0.04 & 0.04 & 0.04 & 0.04 & 0.04 \\
\hline $\mathrm{ZrO}_{2}$ & 0.09 & 0.09 & 0.09 & 0.09 & 0.09 \\
\hline Sum & 100.00 & 100.00 & 100.00 & 100.00 & 100.00 \\
\hline
\end{tabular}

\subsection{Glass Fabrication}

Each sulfate study glass was prepared from the proper proportions of reagent-grade metal oxides, carbonates, boric acid, and salts in $150 \mathrm{~g}$ batches. ${ }^{17}$ The raw materials were thoroughly mixed and placed into a $95 \%$ platinum $/ 5 \%$ gold, $250 \mathrm{~mL}$ crucible. The crucibles were placed into a high-temperature furnace at the target melt temperature of $1150^{\circ} \mathrm{C}{ }^{18}$ After an isothermal hold at $1150^{\circ} \mathrm{C}$ for $1.0 \mathrm{~h}$, the crucibles were removed from the furnace. The glass was poured onto a clean stainless steel plate and allowed to air cool (quench). Visual observations of the quenched glasses and the emptied crucibles were documented. ${ }^{\mathrm{a}}$ The glass pour patty was used as a sampling stock for the chemical composition measurements.

\subsection{Analysis of Glass Composition}

To confirm that the as-fabricated glasses corresponded to the defined target compositions and to determine the amount of sulfate retained in the glasses after melting, a representative sample from each glass was submitted to the SRNL Process Science Analytical Laboratory (PSAL) for chemical analysis under the auspices of an analytical plan. The plan (see Appendix A) identified the cations to be analyzed and the two dissolution techniques, sodium peroxide fusion (PF) and lithium-metaborate (LM), to be used. The samples prepared by LM were used to measure barium

\footnotetext{
a WSRC-NB-2005-00004 (see page 142) contains the visual observations of the quenched glasses.
} 
(Ba), calcium (Ca), cerium (Ce), chromium (Cr), copper (Cu), potassium (K), lanthanum (La), magnesium $(\mathrm{Mg})$, manganese $(\mathrm{Mn})$, sodium $(\mathrm{Na})$, lead $(\mathrm{Pb})$, sulfur $(\mathrm{S})$, thorium $(\mathrm{Th})$, titanium (Ti), zinc (Zn), and zirconium (Zr) concentrations. Samples prepared by PF were used to measure aluminum (Al), boron (B), iron (Fe), lithium ( $\mathrm{Li})$, nickel (Ni), silicon ( $\mathrm{Si})$, and uranium (U) concentrations. Each glass was prepared in duplicate for each cation dissolution technique (PF and LM). All of the prepared samples were analyzed (twice for each element of interest) by Inductively Coupled Plasma - Atomic Emission Spectroscopy (ICP-AES) with the instrumentation being re-calibrated between the duplicate analyses. The analytical plan was developed in such a way as to provide the opportunity to evaluate potential sources of error. Glass standards were also intermittently measured to assess the performance of the ICP-AES instrument over the course of these analyses. However, the standards typically used for high level waste (HLW) glass analysis at SRNL do not contain sulfur. Additional samples of the lowlevel waste reference material (LRM) glass, ${ }^{19-21}$ which contains $0.24 \mathrm{wt} \% \mathrm{SO}_{4}{ }^{2-}$, were also included in the analytical plan to help verify the $\mathrm{SO}_{4}{ }^{2-}$ measurements from PSAL. 
WSRC-STI-2006-00038

Revision 0

\subsection{Results and Discussion}

\subsection{Visual Observations}

Prior to discussing the results, a few words regarding the terminology used to describe the appearance of the glasses are warranted. The use of "clean" or "homogeneous" for visual observations indicates that the sample was classified as a single-phase, amorphous system (i.e., no evidence of crystallization). The description "undissolved material" is indicative of batch chemicals that were not incorporated into the melt before pouring and quenching. Bubbles observed in the glass that remained in the crucible after pouring are likely formed during decomposition of some of the batch chemicals during the melting process.

Table 3-1 contains the visual observations for each of the ten study glasses after pouring and quenching. All of the pour patties appeared amorphous and homogeneous, with no sulfur salt layer apparent on any of the glasses. The lack of a salt layer indicates that either sulfur retention in the glass was good, or some degree of volatilization has occurred. The chemical composition measurements will provide a quantitative measure of the sulfur retention. Small amounts of undissolved batch material were observed in some of the glass remaining in the crucibles. The chemical composition measurements will show that the undissolved batch material had little impact on the composition of the quenched glasses. 
Table 3-1. Visual Observations for the Sulfate Study Glasses.

\begin{tabular}{|c|c|c|l||}
\hline Glass ID & Frit ID & $\begin{array}{c}\text { Target } \mathbf{S O}_{\mathbf{4}}{ }^{2-} \\
\text { (wt \%) }\end{array}$ & \multicolumn{1}{c||}{ Visual Observations } \\
\hline SB4SULFA-01 & 418 & 0.60 & Patty - Clean, homogeneous; Crucible - clean with bubbles \\
\hline SB4SULFA-02 & 418 & 0.65 & Patty - Clean, homogeneous; Crucible - clean with bubbles \\
\hline SB4SULFA-03 & 418 & 0.70 & Patty - Clean, homogeneous; Crucible - clean with bubbles \\
\hline SB4SULFA-04 & 418 & 0.75 & Patty - Clean, homogeneous; Crucible - about four tiny spots of undissolved material, bubbles \\
\hline SB4SULFA-05 & 418 & 0.80 & Patty - Clean, homogeneous; Crucible - about five tiny spots of undissolved material, bubbles \\
\hline SB4SULFA-06 & 503 & 0.60 & Patty - Clean, homogeneous; Crucible - clean with bubbles \\
\hline SB4SULFA-07 & 503 & 0.65 & Patty - Clean, homogeneous; Crucible - clean with bubbles \\
\hline SB4SULFA-08 & 503 & 0.70 & Patty - Clean, homogeneous; Crucible - one spot of undissolved material, bubbles \\
\hline SB4SULFA-09 & 503 & 0.75 & Patty - Clean, homogeneous; Crucible - clean with bubbles \\
\hline SB4SULFA-10 & 503 & 0.80 & Patty - Clean, homogeneous; Crucible - four tiny spots of undissolved material, bubbles \\
\hline
\end{tabular}


WSRC-STI-2006-00038

Revision 0

\subsection{Chemical Composition Measurements}

This section provides a statistical review of the chemical composition measurements. The measured versus targeted compositions of the ten glasses (SB4SULFA-01 through SB4SULFA-10) are presented and compared. The targeted compositions for these glasses are provided in Table 2-2 and Table 2-3, as well as Table B1 of Appendix B. A sum of oxides column is provided in this table as well. Chemical composition measurements for the study glasses were conducted by the PSAL following the analytical plan provided in the Appendix A.

Two dissolution methods, LM and PF, were utilized in measuring these chemical compositions. For each study glass, measurements were obtained from samples prepared in duplicate by each of these dissolution methods. All of the prepared samples were analyzed twice for each element of interest by ICP-AES with the instrumentation being re-calibrated between the duplicate analyses. Note that the analytical plan had indicated that aluminum and nickel would be measured by PF. As these measurements were conducted, a decision was made by PSAL personnel to obtain the measurements for these two elements from the LM dissolution method instead.

Table B2 in Appendix B provides the elemental concentration measurements derived from the samples prepared using LM, and Table B3 in Appendix B provides the measurements derived from the samples prepared using PF. Measurements for standards (Batch 1 and a uranium standard, $\mathrm{U}_{\text {std }}$ ) that were included in the PSAL analytical plan along with the study glasses are also provided in these two tables.

The elemental concentrations were converted to oxide concentrations by multiplying the values for each element by the gravimetric factor for the corresponding oxide. During this process, an elemental concentration that was determined to be below the detection limit of the analytical procedures used by the PSAL was reduced to half of that detection limit as the oxide concentration was determined.

In the sections that follow, the analytical sequences of the measurements are explored, the measurements of the standards are investigated and used for bias correction, the measurements for each glass are reviewed, the average chemical compositions (measured and bias-corrected) for each glass are determined, and comparisons are made between the measurements and the targeted compositions for the glasses.

\subsubsection{Measurements in Analytical Sequence}

Exhibit B1 in Appendix B provides plots of the measurements generated by the PSAL for samples prepared using the LM method. The plots are in analytical sequence with different symbols and colors being used to represent each of the study and standard glasses. Similar plots for the samples prepared using the PF method are provided in Exhibit B2 in Appendix B. These plots include all of the measurement data from Tables B2 and B3. There are several points of interest for these plots. The plots reveal one or more anomalies in the measurements for the LRM samples for $\mathrm{CaO}, \mathrm{Cr}_{2} \mathrm{O}_{3}, \mathrm{La}_{2} \mathrm{O}_{3}, \mathrm{PbO}$, and $\mathrm{ZrO}_{2}$ for the $\mathrm{LM}$ preparation method and for $\mathrm{B}_{2} \mathrm{O}_{3}$ for the PF preparation method. However, the LRM glass was used only to assess the ability of the ICP-AES method to correctly measure $\mathrm{SO}_{4}{ }^{2-}$ concentration, which is discussed further in Section 3.3. Also, in general, there appears to be more scatter in the $\mathrm{SiO}_{2}$ values early in the analytical sequence as opposed to later in the analytical sequence. A closer look at some of these anomalies will be provided in the discussion that follows. 
WSRC-STI-2006-00038

Revision 0

\subsubsection{Batch 1 and Uranium Standard Results}

In this section, the PSAL measurements of the chemical compositions of the Batch 1 and uranium standard $\left(\mathrm{U}_{\mathrm{std}}\right)$ glasses are reviewed. These measurements are investigated across the ICP-AES analytical blocks, and the results are used to bias correct the measurements for the study glasses.

Exhibit B3 in Appendix B provides statistical analyses of the Batch 1 and $\mathrm{U}_{\text {std }}$ results generated by the LM prep method by block/sub-block for each oxide of interest. The results include analysis of variance (ANOVA) investigations looking for statistically significant differences between the means of these groups for each of the oxides for each of the standards. The results from the statistical tests for the Batch 1 standard reveal no indication of a significant ICP-AES calibration effect on the block averages at the $5 \%$ significance level. For the $\mathrm{U}_{\text {std }}$, only MgO has measurements that indicate a significant ICP-AES calibration effect on the block averages at the $5 \%$ significance level. The reference values for the oxide concentrations of the standard are given in the header for each set of measurements in the exhibit.

Exhibit B4 in Appendix B provides a similar set of analyses for the measurements derived from samples prepared via the PF method. The results from the statistical tests for the Batch 1 standard may be summarized as follows: $\mathrm{Fe}_{2} \mathrm{O}_{3}$ and $\mathrm{SiO}_{2}$ have measurements that indicate significant ICP-AES calibration effects on the block averages at the $5 \%$ significance level. For the $U_{\text {std, }}$, $\mathrm{Fe}_{2} \mathrm{O}_{3}, \mathrm{SiO}_{2}$, and $\mathrm{U}_{3} \mathrm{O}_{8}$ have measurements that indicate significant ICP-AES calibration effects on the block averages at the $5 \%$ significance level. The reference values for the oxide concentrations of the standard are given in the headers for each set of measurements in the exhibit.

Thus, some of these results provide incentive for adjusting the measurements by the effects of the ICP-AES calibration. Therefore, the oxide measurements of the study glasses are to be bias corrected for the effect of the ICP-AES calibration on each of the analytical blocks and subblocks. The basis for this bias correction is presented as part of Exhibits $\mathrm{B} 3$ and $\mathrm{B} 4$ - the average measurement for Batch 1 for each ICP-AES block/sub-block for $\mathrm{Al}_{2} \mathrm{O}_{3}, \mathrm{~B}_{2} \mathrm{O}_{3}, \mathrm{BaO}, \mathrm{CaO}, \mathrm{Cr}_{2} \mathrm{O}_{3}$, $\mathrm{CuO}, \mathrm{Fe}_{2} \mathrm{O}_{3}, \mathrm{Li}_{2} \mathrm{O}, \mathrm{MgO}, \mathrm{MnO}, \mathrm{Na}_{2} \mathrm{O}, \mathrm{NiO}, \mathrm{SiO}_{2}$, and $\mathrm{TiO}_{2}$ and the average measurement for $\mathrm{U}_{\text {std }}$ for each ICP-AES set/block for $\mathrm{U}_{3} \mathrm{O}_{8}$. The Batch 1 results served as the basis for bias correcting all of the oxides (that were bias corrected) except uranium. The $U_{\text {std }}$ results were used to bias correct for uranium. For the other oxides, the Batch 1 results were used to conduct the bias correction as long as the reference value for the oxide concentration in the Batch 1 glass was greater than or equal to $0.1 \mathrm{wt} \%$. Thus, applying this approach and based upon the information in the exhibits, the Batch 1 results were used to bias correct the $\mathrm{Al}_{2} \mathrm{O}_{3}, \mathrm{~B}_{2} \mathrm{O}_{3}, \mathrm{BaO}, \mathrm{CaO}, \mathrm{Cr}_{2} \mathrm{O}_{3}, \mathrm{CuO}$, $\mathrm{Fe}_{2} \mathrm{O}_{3}, \mathrm{~K}_{2} \mathrm{O}, \mathrm{Li}_{2} \mathrm{O}, \mathrm{MgO}, \mathrm{MnO}, \mathrm{Na}_{2} \mathrm{O}, \mathrm{NiO}, \mathrm{SiO}_{2}$, and $\mathrm{TiO}_{2}$ measurements. No bias correction was conducted for the $\mathrm{Ce}_{2} \mathrm{O}_{3}, \mathrm{La}_{2} \mathrm{O}_{3}, \mathrm{PbO}$, $\mathrm{ThO}_{2}, \mathrm{ZnO}$, or $\mathrm{ZrO}_{2}$ measurements. Measurements of $\mathrm{SO}_{4}{ }^{2-}$ will be discussed separately in Section 3.3.

The bias correction was conducted as follows. For each oxide, let $\bar{a}_{i j}$ be the average measurement for the $i^{\text {th }}$ oxide at analytical block $j$ for Batch 1 (or $\mathrm{U}_{\text {std }}$ for uranium), and let $t_{i}$ be the reference value for the $i^{\text {th }}$ oxide for Batch 1 (or for $\mathrm{U}_{\text {std }}$ if uranium). (The averages and reference values are provided in Exhibits B3 and B4.) Let $\bar{c}_{i j k}$ be the average measurement for the $i^{\text {th }}$ oxide at analytical block $j$ for the $k^{\text {th }}$ glass. The bias adjustment was conducted as follows

$$
\bar{c}_{i j k} \bullet\left(1-\frac{\bar{a}_{i j}-t_{i}}{\bar{a}_{i j}}\right)=\bar{c}_{i j k} \bullet \frac{t_{i}}{\bar{a}_{i j}}
$$


Bias-corrected measurements are indicated by a "bc" suffix, and such adjustments were performed for all of the oxides of this study except for $\mathrm{Ce}_{2} \mathrm{O}_{3}, \mathrm{La}_{2} \mathrm{O}_{3}, \mathrm{PbO}, \mathrm{SO}_{4}{ }^{2-}, \mathrm{ThO}_{2}, \mathrm{ZnO}$, and $\mathrm{ZrO}_{2}$. Both measured and measured "bc" values are included in the discussion that follows. In these discussions bias-corrected values for $\mathrm{Ce}_{2} \mathrm{O}_{3}, \mathrm{La}_{2} \mathrm{O}_{3}, \mathrm{PbO}, \mathrm{SO}_{4}{ }^{2-}, \mathrm{ThO}_{2}, \mathrm{ZnO}$, and $\mathrm{ZrO}_{2}$ are included for completeness (e.g., to allow a sum of oxides to be computed for the bias-corrected results). These bias-corrected values are the same as the original $\mathrm{Ce}_{2} \mathrm{O}_{3}, \mathrm{La}_{2} \mathrm{O}_{3}, \mathrm{PbO}, \mathrm{SO}_{4}{ }^{2-}, \mathrm{ThO}_{2}$, $\mathrm{ZnO}$, and $\mathrm{ZrO}_{2}$ values.

\subsubsection{Composition Measurements by Glass Number}

Exhibits B5 and B6 in Appendix B provide plots of the oxide concentration measurements by Glass Number (including Batch 1, labeled as glass numbered 100, $\mathrm{U}_{\text {std, }}$ labeled as glass numbered 200, and LRM, labeled as glass numbered 300) by ICP-AES calibration block/sub-block for the measured and bias-corrected (bc) values for the LM and PF preparation methods, respectively. Different symbols and colors are used to represent the different glasses. These plots show the individual measurements across the duplicates of each preparation method and the two ICP-AES calibrations. A review of the plots presented in these exhibits reveals the repeatability of the four individual, oxide values for each study glass as well as the repeatability of the measurements of the standards. Observations from these plots include: one of the $\mathrm{CaO}$ measurements for $\mathrm{U}_{\text {std }}$ appears low and two of the $\mathrm{ZnO}$ measurements for glass SB4SULFA-08 appear high. Several observations for the LRM results were noted: one high value for each of $\mathrm{CaO}, \mathrm{Cr}_{2} \mathrm{O}_{3}, \mathrm{PbO}$, and $\mathrm{ZrO}_{2}$ measurements, two high values for each of $\mathrm{B}_{2} \mathrm{O}_{3}$ and $\mathrm{La}_{2} \mathrm{O}_{3}$ measurements, and two low $\mathrm{B}_{2} \mathrm{O}_{3}$ values as well. The $\mathrm{SO}_{4}{ }^{2-}$ values for the LRM glass are discussed separately in Section 3.3 since it was used as a standard. None of these issues are seen as having any significant impact on the conclusions of this report.

\subsubsection{Measured versus Targeted Compositions}

The four measurements for each oxide for each glass (over both preparation methods) were averaged to determine a representative chemical composition for each glass. These determinations were conducted both for the measured and for the bias-corrected data. A sum of oxides was also computed for each glass based upon both the measured and bias-corrected values. Exhibit B7 in Appendix B provides plots showing results for each glass for each oxide to help highlight the comparisons among the measured, bias-corrected, and targeted values.

Some observations from the plots of Exhibit B7 are offered: For every study glass except SB4SULFA-06, the average measured $\mathrm{Al}_{2} \mathrm{O}_{3}$ values are above the targeted values for this oxide. For nearly every study glass, the average measured $\mathrm{Fe}_{2} \mathrm{O}_{3}$ values, $\mathrm{MgO}$ values, $\mathrm{NiO}$ values, and $\mathrm{SiO}_{2}$ values are less than their respective targeted concentrations. The $\mathrm{ThO}_{2}$ concentrations for all of the study glasses are slightly above target, as well as the $\mathrm{ZnO}$ concentration for glass SB4SULFA-08. In general, bias-correcting helps move the $\mathrm{MgO}, \mathrm{NiO}$, and $\mathrm{SiO}_{2}$ measurements towards their respective targets, and improves the sum of oxides.

Table B4 in Appendix B provides a summary of the average compositions as well as the targeted compositions and some associated differences and relative differences. Notice that the targeted sums of oxides for the standard glasses do not sum to $100 \%$ due to an incomplete coverage of the oxides in the Batch 1 (Glass \# 100), $\mathrm{U}_{\text {std }}$ (Glass \# 200), and LRM (Glass \# 300) glasses. All of the sums of oxides (both measured and bias-corrected) for the study glasses fall within the interval of 95 to $105 \mathrm{wt} \%$. Entries in Table B4 show the relative differences between the measured or bias-corrected values and the targeted values. These differences are shaded when they are greater than or equal to $5 \%$. Overall, these comparisons between the measured and 
targeted compositions suggest only minor difficulties in meeting the targeted compositions for some of the oxides for some of the study glasses.

As noted in the discussion above, there were several anomalies observed in the measurements for the six LRM samples that were included in this analysis. Figure 3-1 provides a closer look at the measurements of this standard glass. In this plot the six samples are labeled 1 through 6 , and all of the oxides are shown. The large scatter in the $\mathrm{B}_{2} \mathrm{O}_{3}, \mathrm{SiO}_{2}$, and $\mathrm{ZrO}_{2}$ measurements noted above is revealed in this plot as well. There is also some scatter in the $\mathrm{Fe}_{2} \mathrm{O}_{3}$ values for sample \#4. None of these issues are seen as having any significant impact on the conclusions of this report since the LRM glass was included as a standard for sulfur, as discussed in the following section. 


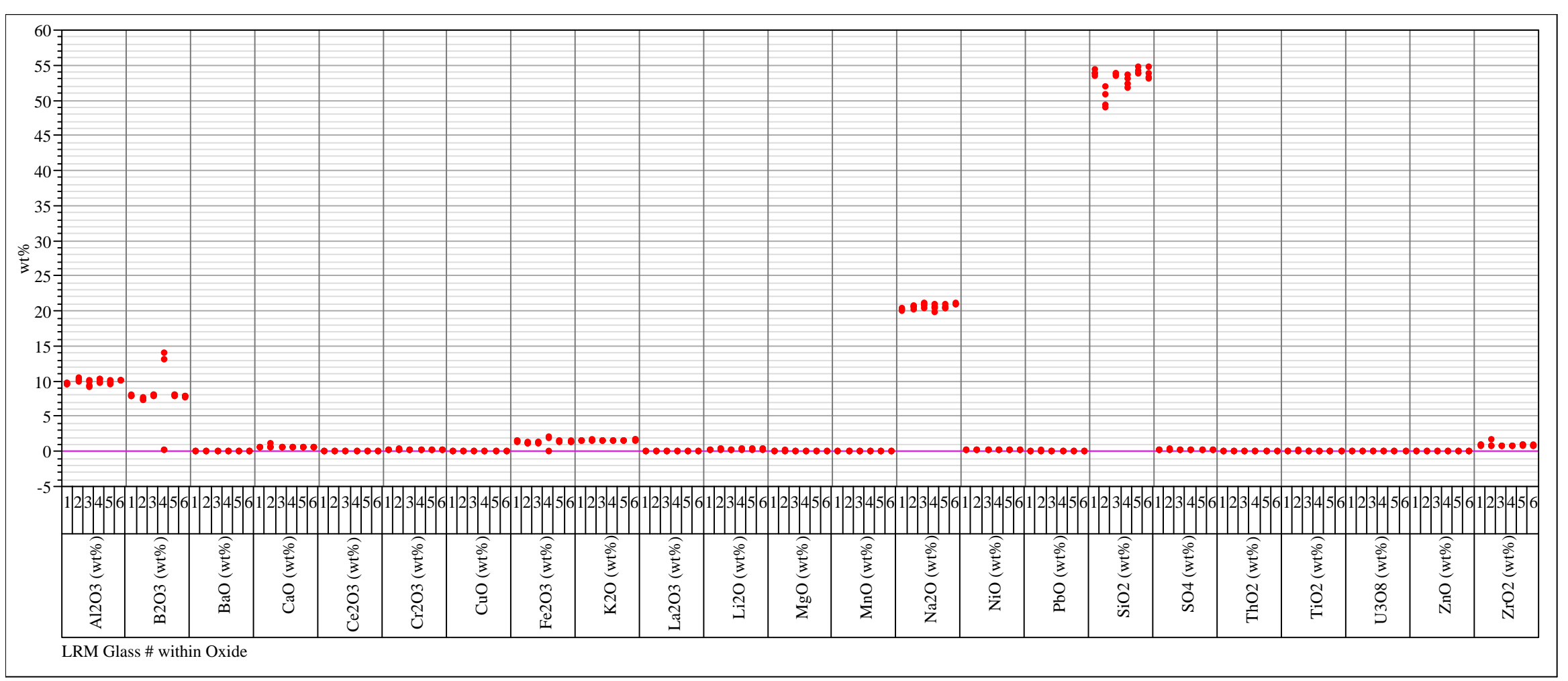

Figure 3-1. Measured Concentrations for the 6 LRM Samples by Oxide 
WSRC-STI-2006-00038

Revision 0

\subsection{Assessment of $\mathrm{SO}_{4}{ }^{2-}$ Values}

The targeted $\mathrm{SO}_{4}{ }^{2-}$ concentrations for the study glasses are all in the range of 0.6 to $0.8 \mathrm{wt} \%$. The $\mathrm{SO}_{4}{ }^{2-}$ measurements versus these targets are reflected in Figure 3-2, a plot of the measured (red crosses) versus targeted (blue line) $\mathrm{SO}_{4}{ }^{2-}$ values for each of the glasses in the analytical plan as well as each of the standards. The Batch 1 and $\mathrm{U}_{\text {std }}$ standard glasses do not contain sulfur. Therefore the target $\mathrm{SO}_{4}{ }^{2-}$ concentration for these two glasses is shown as zero in Figure 3-2, and the measured values are shown as half of the ICP-AES detection limit. A third standard, the LRM glass, was included in this study since it contains a known amount $(0.24 \mathrm{wt} \%)$ of $\mathrm{SO}_{4}{ }^{2-}$. Six specimens of this standard were included throughout the series of measurements since the concentration of $\mathrm{SO}_{4}{ }^{2-}$ retained in the experimental glasses is critical to this study.

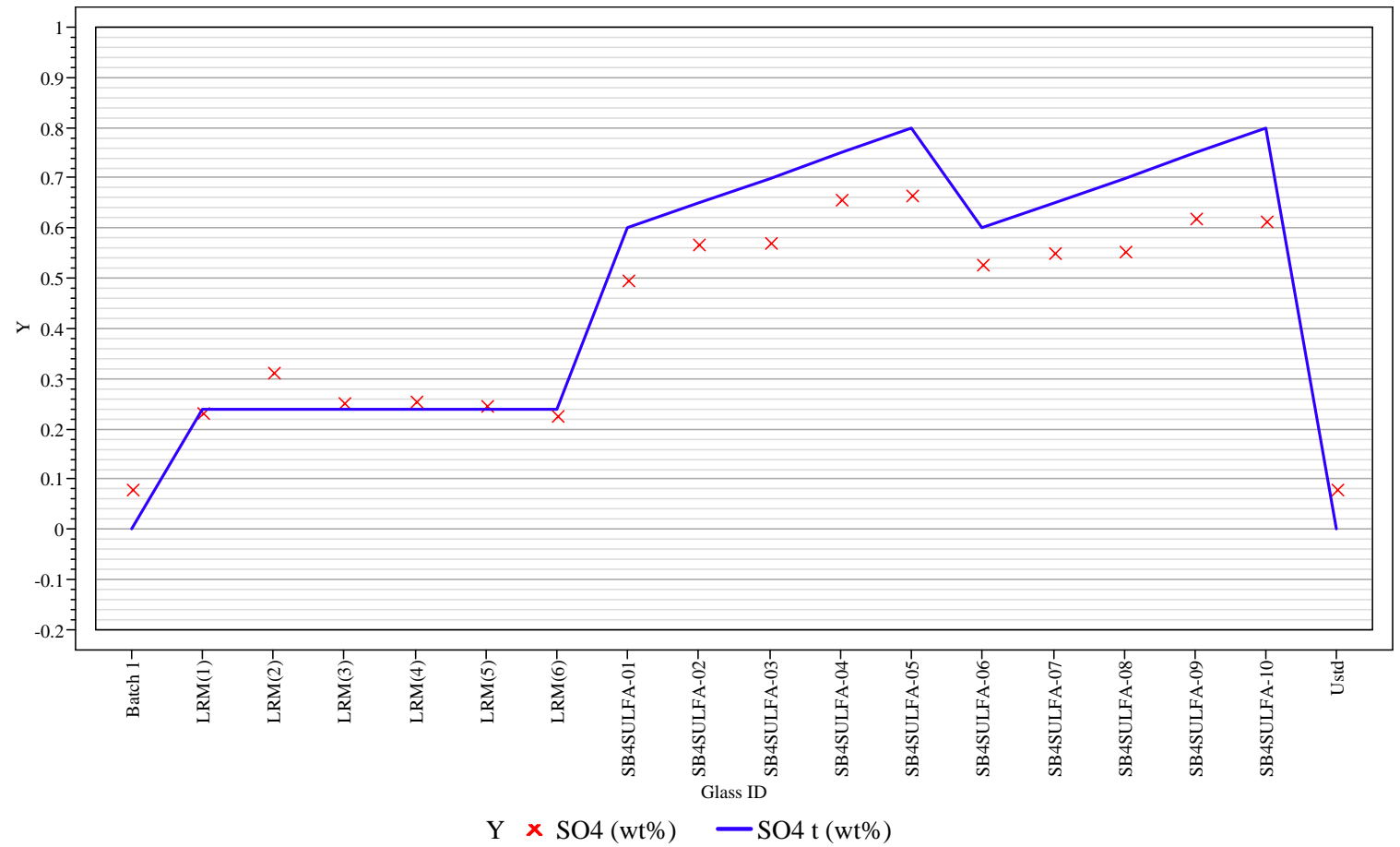

Figure 3-2. $\mathrm{SO}_{4}{ }^{2-}$ Values for Glasses in the Analytical Plan by Glass ID

The target $\mathrm{SO}_{4}{ }^{2-}$ concentration for the LRM glass was $0.24 \mathrm{wt} \%$, and the average measured concentration was $0.25 \mathrm{wt} \%$. The measurements for the LRM samples indicate good sulfate recovery for these analyses, which provides confidence in the sulfate measurements for the study glasses. No bias correction was performed for the $\mathrm{SO}_{4}{ }^{2-}$ values. The averages of the sulfate measurements for all of the study glasses fall consistently below the targeted concentrations. From Table B4, the percent differences range from $12.6 \%$ to $23.8 \%$ below their respective targets for the study glasses. Over the study glasses, the measured sulfate concentrations range from $0.49 \%$ to $0.66 \%$. These results indicate that some sulfate volatilized during the melting of these glasses. However, the four glasses with the highest sulfate concentrations, SB4SULFA-04 and SB4SULFA-05 (Frit 418-based) and SB4SULFA-09 and SB4SULFA-10 (Frit 503-based) retained sulfate at concentrations greater than the limit of $0.6 \mathrm{wt} \%$ established for SB3. ${ }^{9}$ 
WSRC-STI-2006-00038

Revision 0

These data provide insight into the possible $\mathrm{SO}_{4}{ }^{2-}$ retention in $\mathrm{SB} 4$ based glasses. The data suggest that the $0.6 \mathrm{wt} \% \mathrm{SO}_{4}{ }^{2-}$ limit is feasible for this system. 
WSRC-STI-2006-00038

Revision 0

This page intentionally left blank. 


\subsection{Conclusions and Recommendations}

Ten glasses were fabricated in the laboratory using the May 2006 SB4 composition projection and Frits 418 and 503. The glasses were intentionally spiked to relatively high sulfate concentrations of between 0.6 and $0.8 \mathrm{wt} \%$ in the glass (as compared to the nominal value of $0.49 \mathrm{wt} \%$ ). The glasses were batched and melted following standard SRNL procedures. No sulfur salt layer was visually observed on any of the study glasses after pouring and quenching. The measured compositions of each of the glasses met the target values. The LRM glass standard results indicated that sulfate concentration was measured accurately in this study. Sulfate volatilization occurred in all of the study glasses, as evidenced by measured sulfate concentrations that fell below the targeted values. However, the glasses that targeted the highest sulfate concentrations using either Frit 418 or Frit 503 retained sulfate at concentrations at or above the previous limit of $0.6 \mathrm{wt} \%$ established for SB3 processing. These results imply that this same limit may be extended to SB4 processing. Note however that these results are based on a SB4 composition projection provided in May 2006, and may not be technically applicable to revised compositions since sulfate solubility is strongly dependent on glass composition. Upon finalization of the SB4 projected composition, an additional assessment should be performed to ensure that the $0.6 \mathrm{wt} \% \mathrm{SO}_{4}{ }^{2-}$ limit is still viable. 
WSRC-STI-2006-00038

Revision 0

This page intentionally left blank. 
WSRC-STI-2006-00038

Revision 0

\subsection{References}

1. Lilliston, G. R., "Development of Elemental Sludge Compositions for Variations of Sludge Batch 4 (SB4)," U.S. Department of Energy Report CBU-PIT-2004-00011, Revision 1, Westinghouse Savannah River Company, Aiken, South Carolina (2005).

2. Fox, K. M., T. B. Edwards, D. K. Peeler, D. R. Best, I. A. Reamer and R. J. Workman, "Durability and Nepheline Crystallization Study for High Level Waste (HLW) Sludge Batch 4 (SB4) Glasses Formulated with Frit 503," U.S. Department of Energy Report WSRC-STI-200600009, Revision 0, Washington Savannah River Company, Aiken, South Carolina (2006).

3. Fox, K. M., D. K. Peeler, T. B. Edwards, D. R. Best, I. A. Reamer and R. J. Workman, "Nepheline Formation Study for Sludge Batch 4 (SB4): Phase 3 Experimental Results," U.S. Department of Energy Report WSRC-TR-2006-00093, Revision 0, Washington Savannah River Company, Aiken, South Carolina (2006).

4. Peeler, D. K. and T. B. Edwards, "High $\mathrm{B}_{2} \mathrm{O}_{3} / \mathrm{Fe}_{2} \mathrm{O}_{3}$-based Frits: MAR Assessments for Sludge Batch 4 (SB4)," U.S. Department of Energy Report WSRC-TR-2006-00181, Revision 0, Washington Savannah River Company, Aiken, South Carolina (2006).

5. Peeler, D. K., T. B. Edwards, D. R. Best, I. A. Reamer and R. J. Workman, "Nepheline Formation Study for Sludge Batch 4 (SB4): Phase 2 Experimental Results," U.S. Department of Energy Report WSRC-TR-2006-00006, Revision 0, Washington Savannah River Company, Aiken, South Carolina (2006).

6. Smith, M. E., M. E. Stone, T. M. Jones, D. H. Miller and P. R. Burket, "SB4 MRF and SMRF Tests with Frits 418, 425, and 503 (U)," U.S. Department of Energy Report WSRC-STI-200600015, Revision 0, Washington Savannah River Company, Aiken, South Carolina (2006).

7. Bickford, D. F. and C. M. Jantzen, "Inhibitor Limits for Washed Precipitate Based on Glass Quality and Solubility Limits," U.S. Department of Energy Report DPST-86-546, E.I. DuPont deNemours \& Co., Savannah River Laboratory, Aiken, South Carolina (1986).

8. Bickford, D. F., A. Applewhite-Ramsey, C. M. Jantzen and K. G. Brown, "Control of Radioactive Waste Glass Melters: I, Preliminary General Limits at Savannah River," Journal of the American Ceramic Society, 73 [10] 2896-2902 (1990).

9. Peeler, D. K., C. C. Herman, M. E. Smith, T. H. Lorier, D. R. Best, T. B. Edwards and M. A. Baich, "An Assessment of the Sulfate Solubility Limit for the Frit 418 - Sludge Batch 2/3 System," U.S. Department of Energy Report WSRC-TR-2004-00081, Revision 0, Westinghouse Savannah River Company, Aiken, South Carolina (2004).

10. Peeler, D. K., T. B. Edwards and K. M. Fox, "Frit Recommendation for SB4," U.S. Department of Energy Report SRNL-PSE-2006-00128, Washington Savannah River Company, Aiken, South Carolina (2006).

11. Lorier, T. H., T. B. Edwards, I. A. Reamer, D. R. Best and D. K. Peeler, "SB3 Phase 2 Variability Study: The Impact of REDOX on Durability for the Frit 418 - SB2/3 System," U.S. Department of Energy Report WSRC-TR-2003-00539, Westinghouse Savannah River Company, Aiken, South Carolina (2003). 
WSRC-STI-2006-00038

Revision 0

12. Fox, K. M., T. B. Edwards, D. K. Peeler, D. R. Best, I. A. Reamer and R. J. Workman, "High Level Waste (HLW) Sludge Batch 4 (SB4) Variability Study," U.S. Department of Energy Report WSRC-STI-2006-00204, Revision 0, Washington Savannah River Company, Aiken, South Carolina (2006).

13. Fox, K. M., T. B. Edwards and D. K. Peeler, "Sludge Batch 4 (SB4) After a Tank 40 Decant: Candidate Frits, MAR Assessments, and Glasses for a Variability Study," U.S. Department of Energy Report WSRC-STI-2006-00305, Washington Savannah River Company, Aiken, South Carolina (2006).

14. Washburn, F. A., "Technical Task Request: Sludge Batch 4 and MCU Frit Optimization," U.S. Department of Energy Report HLW/DWPF/TTR-2004-0026, Revision 0, Westinghouse Savannah River Company, Aiken, South Carolina (2004).

15. Peeler, D. K., "Task Technical \& QA Plan: Sludge Batch and MCU Frit Optimization," U.S. Department of Energy Report WSRC-RP-2004-00746, Revision 0, Westinghouse Savannah River Company, Aiken, South Carolina (2004).

16. Peeler, D. K. and T. B. Edwards, "Model Based Assessments for SB4 Washing Options: 1.2M Batch/0.91M Blend and 1.4M Batch/0.96M Blend," U.S. Department of Energy Report WSRC-STI-2006-00006, Revision 0, Washington Savannah River Company, Aiken, South Carolina (2006).

17. SRNL, "Glass Batching," U.S. Department of Energy Report SRTC Procedure Manual, L29, ITS-0001, Westinghouse Savannah River Company, Aiken, South Carolina (2002).

18. SRNL, "Glass Melting," U.S. Department of Energy Report SRTC Procedure Manual, L29, ITS-0003, Westinghouse Savannah River Company, Aiken, South Carolina (2002).

19. Ebert, W. L. and S. F. Wolfe, "Dissolution Test for Low-activity Waste Product Acceptance," Proceedings of Spectrum '98, Denver, CO, Sept. 13-18, pp. 724-731 (1998).

20. Ebert, W. L. and S. F. Wolfe, "Round-robin Testing of a Reference Glass for Low-Activity Waste Forms," U.S. Department of Energy Report ANL-99/22, Argonne National Laboratory, Argonne, Illinois (1999).

21. Peeler, D. K., A. D. Cozzi, D. R. Best, C. J. Coleman and I. A. Reamer, "Characterization of the Low Level Waste Reference Glass (LRM)," U.S. Department of Energy Report WSRC-TR-9900095, Revision 0, Westinghouse Savannah River Company, Aiken, South Carolina (1999). 


\section{Appendix A}

\section{An Analytical Plan for Measuring the Chemical Compositions of Glasses from the Sulfate Solubility Study for SB4 (U)}

(SRNL-SCS-2006-00022) 


\section{SRNL-SCS-2006-00022}

July 3, 2006

To:

K. M. Fox, SRNL

cc:

D. R. Best, 786-1A (wo)

S. P. Harris, 773-42A

C. C. Herman, 999-W

D. K. Peeler, 999-W

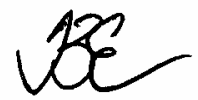

From: T. B. Edwards, 773-42A (5-5148)

Statistical Consulting Section
I. A. Reamer, 999-1W

P. A. Toole, 786-1A (wo)

R. C. Tuckfield, $773-42 \mathrm{~A}$

R. J. Workman, 999-1W
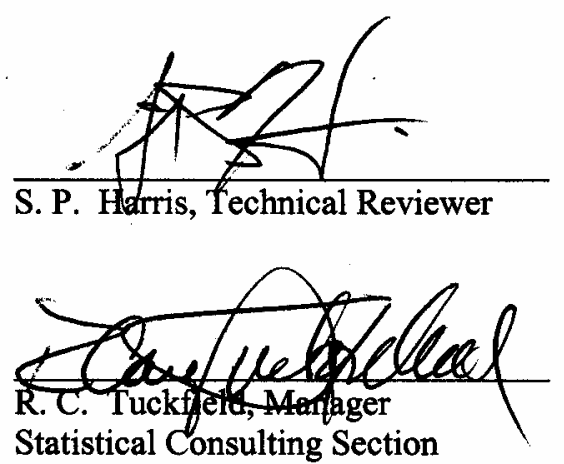

wo - without glass identifiers

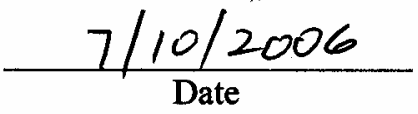

$7 / 10 / 2066$

\section{An Analytical Plan for Measuring THE CHEMICAL COMPOSITIONS OF GLASSES FROM THE SULFATE SOLUBILITY STUDY FOR SB4 (U)}




\subsection{EXECUTIVE SUMMARY}

Frit development efforts are underway at the Savannah River National Laboratory (SRNL) to support the processing of Sludge Batch 4 (SB4) at the Defense Waste Processing Facility (DWPF). One of the questions being considered during these efforts is the sulfate $\left(\mathrm{SO}_{4}^{2-}\right)$ solubility for the SB4 glass system. Since the solubility of $\mathrm{SO}_{4}^{2-}$ is expected to be linked to the frit selected for use with SB4 and Frits 418 and 503 are the leading candidates for such use, these frits were utilized in the selection of ten glasses for this study. The glasses are to be batched and fabricated, and samples are to be taken from each of the study glasses. The samples are to be submitted to SRNL's Process Science Analytical Laboratory (PSAL) for chemical analysis. This memorandum provides an analytical plan to direct and support these measurements at PSAL. 
WSRC-STI-2006-00038

Revision 0

Appendix A (SRNL-SCS-2006-00022)

\subsection{INTRODUCTION}

Frit development efforts are underway at the Savannah River National Laboratory (SRNL) to support the processing of Sludge Batch 4 (SB4) at the Defense Waste Processing Facility (DWPF). One of the questions being considered during these efforts is the sulfate $\left(\mathrm{SO}_{4}^{2-}\right)$ solubility for the SB4 glass system. Since the solubility of $\mathrm{SO}_{4}^{2-}$ is expected to be linked to the frit selected for use with SB4 and Frits 418 and 503 are the leading candidates for such use [1], these frits were utilized to select ten glasses for this study. The glasses were selected from the frit development assessments presented in [2] for the $0.96 \mathrm{M}$ sodium projection of SB4 Blend 1 . The glasses are to be batched and fabricated, and samples are to be taken from each of the study glasses. The samples are to be submitted to SRNL's Process Science Analytical Laboratory (PSAL) for chemical analysis. This memorandum provides an analytical plan to direct and support these measurements at PSAL.

\subsection{Anal ytical Plan}

The analytical procedures used by PSAL to determine cation concentrations for a glass sample include steps for sample preparation and for instrument calibration. Each glass is to be prepared in duplicate by each of two dissolution methods: lithium metaborate fusion (LM) and sodium peroxide fusion (PF).

The primary measurements of interest are to be acquired as follows. The samples prepared by $\mathrm{LM}$ are to be measured for barium $(\mathrm{Ba})$, calcium $(\mathrm{Ca})$, cerium $(\mathrm{Ce})$, chromium $(\mathrm{Cr})$, copper $(\mathrm{Cu})$, potassium $(\mathrm{K})$, lanthanum $(\mathrm{La})$, magnesium $(\mathrm{Mg})$, manganese $(\mathrm{Mn})$, sodium $(\mathrm{Na})$, lead $(\mathrm{Pb})$, sulfur (S), thorium (Th), titanium (Ti), zinc (Zn), and zirconium (Zr) concentrations. Samples prepared by PF are to be measured for aluminum (Al), boron (B), iron (Fe), lithium (Li), nickel (Ni), silicon (Si), and uranium (U) concentrations. Samples dissolved by both preparation methods are to be measured using Inductively Coupled Plasma - Atomic Emission Spectrometry (ICP-AES). It should be noted that some of these elements are minor components that may be near the detection limits for most, if not all, of the study glasses.

Randomizing the preparation steps and blocking and randomizing the measurements for the ICPAES are of primary concern in the development of this analytical plan. The sources of uncertainty for the analytical procedure used by PSAL to determine the cation concentrations for the submitted glass samples are dominated by the dissolution step in the preparation of the sample and by the calibrations of the ICP-AES.

Samples of glass standards will be included in the analytical plan to provide an opportunity for checking the performance of the instrumentation over the course of the analyses and for potential bias correction. Specifically, several samples of Waste Compliance Plan (WCP) Batch 1 (BCH) [3] and a uranium standard glass (Ustd) are included in this analytical plan. The reference compositions of these glasses are provided in Table 1.

In addition, samples of the Low-Activity Reference Material (LRM) standard glass (which contains sulfur - see [4] for details on the chemical composition of this glass) are to be included in the set of samples submitted to PSAL. The measurements of this glass will be used to provide insight into the uncertainty of PSAL's sulfur measurements. The LRM samples are to be labeled in the same manner as the study glasses, but with their labels known. The labels are being 
WSRC-STI-2006-00038

Revision 0

Appendix A (SRNL-SCS-2006-00022)

provided to assist in the interpretation of the sums of oxides for the glasses. Since some of the elements present in LRM are not listed above (i.e., they will not be measured by PSAL), the measured sum of oxides for LRM may fall below 95\% (i.e., the target sum of oxides for LRM for the elements listed above is only around $97.7 \%$ ).

Table 1: Oxide Compositions of WCP Batch 1 (BCH) and Ustd

\begin{tabular}{||c|c|c||}
\hline $\begin{array}{c}\text { Oxide/ } \\
\text { Anion }\end{array}$ & $\begin{array}{c}\text { BCH } \\
\text { (wt \%) }\end{array}$ & $\begin{array}{c}\text { Ustd } \\
\text { (wt \%) }\end{array}$ \\
\hline $\mathrm{Al}_{2} \mathrm{O}_{3}$ & 4.877 & 4.1 \\
\hline $\mathrm{B}_{2} \mathrm{O}_{3}$ & 7.777 & 9.209 \\
\hline $\mathrm{BaO}$ & 0.151 & 0 \\
\hline $\mathrm{CaO}$ & 1.22 & 1.301 \\
\hline $\mathrm{Cr}_{2} \mathrm{O}_{3}$ & 0.107 & 0 \\
\hline $\mathrm{Cs}_{2} \mathrm{O}$ & 0.06 & 0 \\
\hline $\mathrm{CuO}$ & 0.399 & 0 \\
\hline $\mathrm{Fe}_{2} \mathrm{O}_{3}$ & 12.839 & 13.196 \\
\hline $\mathrm{K}_{2} \mathrm{O}$ & 3.327 & 2.999 \\
\hline $\mathrm{Li}_{2} \mathrm{O}$ & 4.429 & 3.057 \\
\hline $\mathrm{MgO} \mathrm{O}$ & 1.21 \\
\hline $\mathrm{MnO} \mathrm{O} O$ & 2.892 \\
\hline $\mathrm{Na}_{2} \mathrm{O}$ & 1.419 & 11.795 \\
\hline $\mathrm{Nd}_{2} \mathrm{O}_{3}$ & 1.726 & 0 \\
\hline $\mathrm{NiO}_{\mathrm{RuO}}$ & 9.003 & 1.12 \\
\hline $\mathrm{SiO}_{2}$ & 0.147 & 0 \\
\hline $\mathrm{SO}_{3}$ & 0.751 & 45.353 \\
\hline $\mathrm{TiO}_{2}$ & 0.0214 & 0 \\
\hline $\mathrm{U}_{3} \mathrm{O}_{8}$ & 50.22 & 1.049 \\
\hline $\mathrm{ZrO}_{2}$ & 0 & 2.406 \\
\hline & 0.677 & 0 \\
\hline
\end{tabular}

Each glass sample submitted to PSAL will be prepared in duplicate by the LM and PF dissolution methods. Every prepared sample will be read twice by ICP-AES, with the instrument being calibrated before each of these two sets of readings. This will lead to four measurements for each cation of interest for each submitted glass.

Table 2 presents identifying codes, M01 through M16, for the 10 glasses fabricated for this study and the 6 samples of the LRM standard that have been included. The table provides a naming convention that is to be used in analyzing the glasses and reporting the measurements of their compositions. ${ }^{3}$

3 Renaming these samples helps to ensure that they will be processed as blind samples within PSAL. Table 2 is not shown in its entirety in the copies going to PSAL. However, note that the LRM glasses are to be identified. 
WSRC-STI-2006-00038

Revision 0

Appendix A (SRNL-SCS-2006-00022)

Table 2: Glass Identifiers to Establish Blind Samples for PSAL

\begin{tabular}{|c|c|c|c||}
\hline Glass ID & $\begin{array}{c}\text { Sample } \\
\text { ID }\end{array}$ & Glass ID & $\begin{array}{c}\text { Sample } \\
\text { ID }\end{array}$ \\
\hline SB4SULFA-01 & M03 & SB4SULFA-09 & M11 \\
\hline SB4SULFA-02 & M15 & SB4SULFA-10 & M06 \\
\hline SB4SULFA-03 & M05 & LRM(1) & M12 \\
\hline SB4SULFA-04 & M02 & LRM(2) & M09 \\
\hline SB4SULFA-05 & M13 & LRM(3) & M10 \\
\hline SB4SULFA-06 & M16 & LRM(4) & M08 \\
\hline SB4SULFA-07 & M04 & LRM(5) & M01 \\
\hline SB4SULFA-08 & M07 & LRM(6) & M14 \\
\hline
\end{tabular}

\subsection{PREPARATION OF THE SAMPLES}

Each of the 16 glasses included in this analytical plan is to be prepared in duplicate by the LM and PF dissolution methods. Thus, the total number of prepared glass samples is determined by $16 \cdot 2 \cdot 2=64$, not including the samples of the $\mathrm{BCH}$ and Ustd glass standards that are to be prepared.

Table 3 provides blocking and (random) sequencing schema for conducting the preparation steps of the analytical procedures. One block of preparation work is provided for each preparation method to facilitate the scheduling of activities by work shift. The identifier for each of the prepared samples indicates the sample identifier (ID), preparation method, and duplicate number. 
WSRC-STI-2006-00038

Revision 0

Appendix A (SRNL-SCS-2006-00022)

Table 3: Preparation Blocks by Dissolution Method

\begin{tabular}{|c|c|}
\hline LM (Lithium Metaborate) & PF (Peroxide Fusion) \\
\hline M03LM1 & M10PF1 \\
\hline M10LM1 & M06PF1 \\
\hline M03LM2 & M10PF2 \\
\hline M07LM1 & M07PF1 \\
\hline M04LM1 & M07PF2 \\
\hline M09LM1 & M02PF1 \\
\hline M08LM1 & M08PF1 \\
\hline M13LM1 & M11PF1 \\
\hline M11LM1 & M06PF2 \\
\hline M04LM2 & M08PF2 \\
\hline M10LM2 & M15PF1 \\
\hline M16LM1 & M03PF1 \\
\hline M14LM1 & M03PF2 \\
\hline M11LM2 & M01PF1 \\
\hline M14LM2 & M05PF1 \\
\hline M07LM2 & M16PF1 \\
\hline M15LM1 & M13PF1 \\
\hline M09LM2 & M11PF2 \\
\hline M01LM1 & M13PF2 \\
\hline M08LM2 & M12PF1 \\
\hline M13LM2 & M15PF2 \\
\hline M16LM2 & M14PF1 \\
\hline M02LM1 & M09PF1 \\
\hline M06LM1 & M02PF2 \\
\hline M05LM1 & M05PF2 \\
\hline M15LM2 & M04PF1 \\
\hline M12LM1 & M12PF2 \\
\hline M12LM2 & M14PF2 \\
\hline M02LM2 & M01PF2 \\
\hline M05LM2 & M16PF2 \\
\hline M01LM2 & M09PF2 \\
\hline M06LM2 & M04PF2 \\
\hline
\end{tabular}

\subsection{ICP-AES Calibration Blocks}

The glass samples prepared by the LM and PF dissolution methods are to be analyzed using ICPAES instrumentation calibrated for the particular preparation method. After the initial set of cation concentration measurements, the ICP-AES instrumentation is to be recalibrated and a second set of concentration measurements for the cations determined.

Randomized plans for measuring cation concentrations in the LM-prepared and PF-prepared samples are provided in Table 4. The cations to be measured are specified as part of the table. In the tables, the sample identifiers for the study glasses have been modified by the addition of a suffix (a " 1 "or a " 2 ") to indicate whether the measurement was made during the first or second (respectively) calibration of the ICP-AES instrumentation. The identifiers for the BCH and Ustd samples have been modified to indicate the ICP-AES calibration block and that each of these prepared samples is to be read 3 times (mirrored in the corresponding suffix of 1, 2, or 3) per calibration block. 
WSRC-STI-2006-00038

Revision 0

Appendix A (SRNL-SCS-2006-00022)

Table 4: ICP-AES Blocks \& Calibration Groups by Preparation Method

\begin{tabular}{|c|c|c|c|c|c|c|c|}
\hline \multicolumn{4}{|c|}{ "LM Glass Samples } & \multicolumn{4}{|c|}{ PF Glass Samples } \\
\hline \multicolumn{4}{|c|}{$\begin{array}{c}\text { Used to Measure Elemental Ba, Ca, Ce, Cr, Cu, K, } \\
\text { La, Mg, Mn, Na, Pb, S, Th, Ti, Zn, \& Zr } \\
\end{array}$} & \multicolumn{4}{|c|}{$\begin{array}{l}\text { Used to Measure Elemental Al, B, Fe, Li, Ni, } \\
\qquad \mathrm{Si}, \& \mathrm{U}\end{array}$} \\
\hline \multicolumn{4}{|c|}{ LM Calibration Blocks } & \multicolumn{4}{|c|}{ PF Calibration Blocks } \\
\hline Block 1-1 & Block 1-2 & Block 2-1 & Block 2-2 & Block 1-1 & Block 1-2 & Block 2-1 & Block 2-2 \\
\hline BCHLM111 & BCHLM121 & BCHLM211 & BCHLM221 & BCHPF111 & BCHPF121 & BCHPF211 & BCHPF221 \\
\hline UstdLM111 & UstdLM121 & UstdLM211 & UstdLM221 & UstdPF111 & UstdPF121 & \begin{tabular}{|l|} 
UstdPF211 \\
\end{tabular} & UstdPF221 \\
\hline M03LM11 & M10LM12 & M06LM21 & M09LM12 & M05PF21 & M04PF22 & M16PF11 & M13PF22 \\
\hline M10LM21 & M05LM22 & M16LM21 & M02LM12 & M09PF21 & M08PF22 & M13PF11 & M14PF12 \\
\hline M14LM11 & M15LM22 & M02LM21 & M06LM12 & M08PF21 & M06PF12 & M12PF21 & M13PF12 \\
\hline M13LM21 & M12LM22 & M09LM21 & M09LM22 & M08PF11 & M09PF12 & M10PF21 & M16PF22 \\
\hline M05LM21 & M15LM12 & M04LM11 & M07LM12 & M09PF11 & M04PF12 & M10PF11 & M16PF12 \\
\hline M03LM21 & M13LM12 & M07LM11 & M04LM22 & M11PF21 & M02PF22 & M01PF21 & M01PF12 \\
\hline M12LM21 & M01LM22 & M08LM11 & M07LM22 & M07PF11 & M06PF22 & M03PF11 & M01PF22 \\
\hline M12LM11 & M14LM12 & M11LM11 & M08LM12 & M02PF11 & M07PF22 & M14PF21 & M10PF22 \\
\hline BCHLM112 & BCHLM122 & BCHLM212 & BCHLM222 & BCHPF112 & BCHPF122 & BCHPF212 & BCHPF222 \\
\hline UstdLM112 & UstdLM122 & UstdLM212 & UstdLM222 & UstdPF112 & UstdPF122 & UstdPF212 & UstdPF222 \\
\hline M05LM11 & M12LM12 & M06LM11 & M08LM22 & M02PF21 & M11PF12 & M13PF21 & M10PF12 \\
\hline M13LM11 & M14LM22 & M09LM11 & M02LM22 & M04PF11 & M08PF12 & M03PF21 & M12PF22 \\
\hline M15LM11 & M03LM22 & M11LM21 & M11LM12 & M11PF11 & M02PF12 & M16PF21 & M15PF12 \\
\hline M01LM21 & M03LM12 & M16LM11 & M16LM22 & M06PF11 & M05PF12 & M01PF11 & M03PF12 \\
\hline M14LM21 & M01LM12 & M07LM21 & M11LM22 & M06PF21 & M09PF22 & M15PF21 & M14PF22 \\
\hline M10LM11 & M13LM22 & M08LM21 & M16LM12 & M07PF21 & M05PF22 & M12PF11 & M03PF22 \\
\hline M15LM21 & M05LM12 & M04LM21 & M04LM12 & M05PF11 & M07PF12 & M15PF11 & M15PF22 \\
\hline M01LM11 & M10LM22 & M02LM11 & M06LM22 & M04PF21 & M11PF22 & M14PF11 & M12PF12 \\
\hline BCHLM113 & BCHLM123 & BCHLM213 & BCHLM223 & BCHPF113 & BCHPF123 & \begin{tabular}{|l} 
BCHPF213 \\
\end{tabular} & BCHPF223 \\
\hline UstdLM113 & UstdLM123 & UstdLM213 & UstdLM223 & UstdPF113 & UstdPF123 & \begin{tabular}{|l|} 
UstdPF213 \\
\end{tabular} & UstdPF223 \\
\hline
\end{tabular}

\subsection{Concluding Comments}

In summary, this analytical plan identifies two preparation blocks in Table 3 and eight ICP-AES calibration blocks in Table 4 for use by PSAL. The sequencing of the activities associated with each of the steps in the analytical procedures has been randomized. The size of each of the blocks was selected so that it could be completed in a single work shift.

If a problem is discovered while measuring samples in a calibration block, the instrument should be re-calibrated and the block of samples re-measured in its entirety. If for some reason the measurements are not conducted in the sequences presented in this report, a record should be made of the actual order used along with any explanative comments.

The analytical plan indicated in the preceding tables should be modified by the personnel of PSAL to include any calibration check standards and/or other standards that are part of their routine operating procedures. It is also recommended that the solutions resulting from each of the prepared samples be archived for some period, considering the "shelf-life" of the solutions, in case questions arise during data analysis. This would allow for the solutions to be rerun without additional preparations, thus minimizing cost. 
WSRC-STI-2006-00038

Revision 0

Appendix A (SRNL-SCS-2006-00022)

\subsection{REFERENCES}

[1] Peeler, D.K., T.B. Edwards, and K.M. Fox, "Frit Recommendation for SB4," SRNLPSE-2006-00128, June 23, 2006.

[2] Peeler, D.K. and T.B. Edwards, "Model Based Assessments for SB4 Washing Options: 1.2M Batch/0.91M Blend and 1.4M Batch/0.96M Blend,” WSRC-STI-2006-00006, June 2006.

[3] Jantzen, C.M., J.B. Pickett, K.G. Brown, T.B. Edwards, and D.C. Beam, "Process/ Product Models for the Defense Waste Processing Facility (DWPF): Part I. Predicting Glass Durability from Composition Using a Thermodynamic Hydration Energy Reaction Model (THERMO ${ }^{\mathrm{TM}}$ ) (U)," WSRC-TR-93-673, Revision 1, Volume 2, Table B.1, pp. B.9, 1995.

[4] Ebert, W.L. and S.F. Wolf, "Round-Robin Testing of a Reference Glass for Low-Activity Waste Forms,” ANL-99/22, Argonne National Laboratory, Argonne, IL, October, 1999. 


\section{Appendix B}

\section{Tables and Exhibits Supporting the Analysis of the Chemical Composition Measurements of the SB4 Sulfate Study Glasses}


Table B1. Targeted Oxide Concentrations (in wt\%) for the SB4 Sulfate Solubility Study Glasses

\begin{tabular}{|c|c|c|c|c|c|c|c|c|c|c|c|c|c|c|c|c|c|c|c|c|c|c|c|c|}
\hline Glass \# & $\mathbf{A l}_{2} \mathbf{O}_{3}$ & $\mathrm{~B}_{2} \mathbf{O}_{3}$ & BaO & $\mathrm{CaO}$ & $\mathrm{Ce}_{2} \mathrm{O}_{3}$ & $\mathrm{Cr}_{2} \mathrm{O}_{3}$ & $\mathrm{CuO}$ & $\mathrm{Fe}_{2} \mathrm{O}_{3}$ & $\mathbf{K}_{2} \mathbf{O}$ & $\mathbf{L a}_{2} \mathbf{O}_{3}$ & $\mathrm{Li}_{2} \mathrm{O}$ & MgO & MnO & $\mathrm{Na}_{2} \mathrm{O}$ & $\mathrm{NiO}$ & PbO & $\mathrm{SO}_{4}{ }^{2-}$ & $\mathrm{SiO}_{2}$ & $\mathrm{ThO}_{2}$ & $\mathrm{TiO}_{2}$ & $\mathbf{U}_{3} \mathbf{O}_{8}$ & $\mathrm{ZnO}$ & $\mathrm{ZrO}_{2}$ & Sum \\
\hline SB4SULFA-01 & 8.93 & 4.95 & 0.05 & 0.90 & 0.06 & 0.08 & 0.02 & 10.04 & 0.12 & 0.04 & 4.95 & 0.96 & 2.07 & 13.97 & 0.59 & 0.04 & 0.60 & 48.56 & 0.02 & 0.01 & 2.91 & 0.04 & 0.09 & 100 \\
\hline SB4SULFA-02 & 8.92 & 4.95 & 0.05 & 0.90 & 0.06 & 0.08 & 0.02 & 10.03 & 0.12 & 0.04 & 4.95 & 0.96 & 2.07 & 13.96 & 0.59 & 0.04 & 0.65 & 48.54 & 0.02 & 0.01 & 2.91 & 0.04 & 0.09 & 100 \\
\hline SB4SULFA-03 & 8.92 & .95 & 0.05 & 0.90 & 06 & .08 & 02 & 10.03 & 0.12 & 04 & 4.95 & 0.96 & 2.07 & 13.96 & 0.59 & 0.04 & 0.70 & 48.52 & 0.02 & 0.01 & 2.91 & 0.04 & 0.09 & 00 \\
\hline SB4SULFA-04 & 8.91 & 4.95 & 0.05 & 0.90 & 0.06 & 0.08 & 0.02 & 10.02 & 0.12 & 0.04 & 4.95 & 0.96 & 2.06 & 13.95 & 0.59 & 0.04 & 0.75 & 48.49 & 0.02 & 0.01 & 2.91 & 0.04 & 0.09 & 100 \\
\hline SB4SULFA-05 & 8.91 & 4.94 & 0.05 & 0.90 & 0.06 & 0.08 & 0.02 & 10.02 & 0.12 & 0.04 & 4.94 & 0.96 & 2.06 & 13.94 & 0.59 & 0.04 & 0.80 & 48.47 & 0.02 & 0.01 & 2.91 & 0.04 & 0.09 & 100 \\
\hline SB4SULFA-06 & 8.93 & 8.67 & 0.05 & 0.90 & 0.06 & 0.08 & 0.02 & 10.04 & 0.12 & 0.04 & 4.95 & 0.96 & 2.07 & 11.49 & 0.59 & 0.04 & 0.60 & 47.33 & 0.02 & 0.01 & 2.91 & 0.04 & 0.09 & 100 \\
\hline SB4SULFA-07 & 8.92 & 8.67 & 0.05 & 0.90 & 0.06 & 0.08 & 0.02 & 10.03 & 0.12 & 0.04 & 4.95 & 0.96 & 2.07 & 11.49 & 0.59 & 0.04 & 0.65 & 47.30 & 0.02 & 0.01 & 2.91 & 0.04 & 0.09 & 100 \\
\hline SB4SULFA-08 & 8.92 & 8.66 & 0.05 & 0.90 & 0.06 & 0.08 & 0.02 & 10.03 & 0.12 & 0.04 & 4.95 & 0.96 & 2.07 & 11.48 & 0.59 & 0.04 & 0.70 & 47.28 & 0.02 & 0.01 & 2.91 & 0.04 & 0.09 & 100 \\
\hline SB4SULFA-09 & 8.91 & 8.66 & 0.05 & 0.90 & 0.06 & 0.08 & 0.02 & 10.02 & 0.12 & 0.04 & 4.95 & 0.96 & 2.06 & 11.48 & 0.59 & 0.04 & 0.75 & 47.25 & 0.02 & 0.01 & 2.91 & 0.04 & 0.09 & 100 \\
\hline SB4SULFA-10 & 8.91 & 8.65 & 0.05 & 0.90 & 0.06 & 0.08 & 0.02 & 10.02 & 0.12 & 0.04 & \begin{tabular}{|l|l|}
4.94 \\
\end{tabular} & 0.96 & 2.06 & 11.47 & 0.59 & 0.04 & 0.80 & 47.23 & 0.02 & 0.01 & 2.91 & 0.04 & 0.09 & 100 \\
\hline
\end{tabular}


Table B2. Measured Elemental Concentrations (in wt\%) for Samples Prepared Using Lithium Metaborate

\begin{tabular}{|c|c|c|c|c|c|c|c|c|c|c|c|c|c|c|c|c|c|c|c|c|c|c|}
\hline Glass ID & Laboratory ID & Block & $\begin{array}{l}\text { Sub- } \\
\text { Block }\end{array}$ & $\begin{array}{c}\text { Analytical } \\
\text { Sequence }\end{array}$ & Al & Ba & Ca & $\mathrm{Ce}$ & $\mathrm{Cr}$ & $\mathrm{Cu}$ & $\mathbf{K}$ & La & Mg & Mn & $\mathrm{Na}$ & $\mathrm{Ni}$ & $\mathbf{P b}$ & S & Th & Ti & Zn & $\mathbf{Z r}$ \\
\hline Batch 1 & BCHLM111 & 1 & 1 & 1 & 2.49 & $\begin{array}{l}0.124 \\
\end{array}$ & 0.879 & $<0.010$ & 0.067 & 0.325 & 2.89 & $<0.010$ & 0.802 & 1.29 & 6.87 & 0.551 & $<0.020$ & $<0.050$ & $<0.100$ & 0.380 & $<0.010$ & 0.064 \\
\hline Ustd & tdLM111 & 1 & 1 & 2 & 2.59 & 0.136 & 0.885 & $<0.010$ & 0.070 & 0.331 & 3.00 & $<0.010$ & 0.875 & 1.29 & 7.17 & 0.545 & $<0.020$ & $<0.050$ & $<0.100$ & 0.385 & $<0.010$ & $<0.010$ \\
\hline SB4SULFA-01 & M03LM11 & 1 & 1 & 3 & 2.49 & 0.135 & 0.904 & $<0.010$ & 0.073 & 0.333 & 2.93 & $<0.010$ & 0.876 & 1.19 & 7.03 & 0.505 & $<0.020$ & $<0.050$ & $<0.100$ & 0.402 & $<0.010$ & 0.070 \\
\hline LRM(3) & M10LM21 & 1 & 1 & 4 & 2.51 & 0.124 & 0.887 & $<0.010$ & 0.068 & 0.325 & 2.90 & $<0.010$ & 0.795 & 1.25 & 6.93 & 0.532 & $<0.020$ & $<0.050$ & $<0.100$ & 0.375 & $<0.010$ & 0.065 \\
\hline LRM(6) & M14LM11 & 1 & 1 & 5 & 2.54 & 0.122 & 0.897 & $<0.010$ & 0.067 & 0.328 & 2.97 & $<0.010$ & 0.790 & 1.25 & 7.13 & 0.531 & $<0.020$ & $<0.050$ & $<0.100$ & 0.383 & $<0.010$ & 0.067 \\
\hline SB4SULFA-05 & M13LM21 & 1 & 1 & 6 & 2.51 & $\begin{array}{l}0.120 \\
\end{array}$ & 0.899 & $<0.010$ & 0.066 & 0.328 & 2.94 & $<0.010$ & 0.787 & 1.17 & 7.08 & 0.503 & $<0.020$ & $<0.050$ & $<0.100$ & 0.377 & $<0.010$ & 0.066 \\
\hline SB4SULFA-03 & M05LM21 & 1 & 1 & 7 & 2.49 & 0.120 & 0.874 & $<0.010$ & 0.064 & 0.322 & 2.87 & $<0.010$ & 0.797 & 1.33 & 6.83 & 0.574 & $<0.020$ & $<0.050$ & $<0.100$ & 0.369 & $<0.010$ & 0.063 \\
\hline SB4SULFA-01 & M03LM21 & 1 & 1 & 8 & 2.48 & 0.121 & 0.883 & $<0.010$ & 0.065 & 0.327 & 2.83 & $<0.010$ & 0.799 & 1.33 & 6.85 & 0.571 & $<0.020$ & $<0.050$ & $<0.100$ & 0.379 & $<0.010$ & 0.063 \\
\hline LRM(1) & M12LM21 & 1 & 1 & 9 & 2.48 & 0.127 & 0.887 & $<0.010$ & 0.067 & 0.328 & 2.86 & $<0.010$ & 0.844 & 1.28 & 6.91 & 0.541 & $<0.020$ & $<0.050$ & $<0.100$ & 0.390 & $<0.010$ & 0.066 \\
\hline LRM(1) & 12LM11 & 1 & 1 & 10 & 2.50 & 0.123 & 0.881 & $<0.010$ & 0.068 & 0.325 & 2.89 & $<0.010$ & 0.802 & 1.28 & 6.90 & 0.550 & $<0.020$ & $<0.050$ & $<0.100$ & 0.378 & $<0.010$ & 0.065 \\
\hline Batch 1 & LHLM112 & 1 & 1 & 11 & 2.49 & 0.125 & 0.884 & $<0.010$ & 0.069 & 0.326 & 2.91 & $<0.010$ & 0.806 & 1.23 & 7.01 & 0.531 & $<0.020$ & $<0.050$ & $<0.100$ & 0.381 & $<0.010$ & 0.067 \\
\hline Ustd & UstdLM112 & 1 & 1 & 12 & 2.50 & $\begin{array}{ll}0.121 \\
\end{array}$ & 0.888 & $<0.010$ & 0.067 & 0.325 & 2.90 & $<0.010$ & 0.791 & 1.24 & 7.00 & 0.530 & $<0.020$ & $<0.050$ & $<0.100$ & 0.377 & $<0.010$ & 0.065 \\
\hline SB4SULFA & 05LM11 & 1 & 1 & 13 & 5.15 & $<0.010$ & 0.382 & $<0.010$ & 0.131 & $<0.010$ & 1.30 & $<0.010$ & 0.059 & 0.010 & 15.0 & 0.124 & 0.070 & 0.087 & $<0.100$ & 0.057 & $<0.010$ & 0.662 \\
\hline SB4SULFA-05 & 13LM11 & 1 & 1 & 14 & 5.06 & $<0.010$ & 0.374 & $<0.010$ & 0.132 & $<0.010$ & 1.27 & 0.010 & 0.062 & $<0.010$ & 15.0 & 0.125 & 0.073 & 0.078 & $<0.100$ & 0.059 & $<0.010$ & 0.678 \\
\hline SB4SULFA-02 & 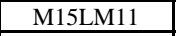 & 1 & 1 & 15 & 5.12 & $<0.010$ & 0.385 & $<0.010$ & 0.125 & $<0.010$ & 1.29 & $<0.010$ & 0.056 & $<0.010$ & 14.9 & 0.123 & 0.068 & 0.073 & $<0.100$ & 0.055 & $<0.010$ & 0.645 \\
\hline LRM(5) & M01LM21 & 1 & 1 & 16 & 5.08 & $<0.010$ & 0.381 & $<0.010$ & 0.122 & $<0.010$ & 1.27 & $<0.010$ & 0.056 & $<0.010$ & 15.1 & 0.134 & 0.069 & 0.065 & $<0.100$ & 0.056 & $<0.010$ & 0.651 \\
\hline LRM(6) & M14LM21 & 1 & 1 & 17 & 5.26 & $<0.010$ & 0.827 & $<0.010$ & 0.245 & $<0.010$ & 1.29 & 0.012 & 0.109 & $<0.010$ & 15.0 & 0.147 & 0.128 & 0.145 & $<0.100$ & 0.106 & $<0.010$ & 1.213 \\
\hline LRM(3) & & 4 & 1 & 18 & 5.50 & $<0.010$ & 0.418 & $<0.010$ & 0.127 & $<0.010$ & 1.32 & $<0.010$ & 0.056 & $<0.010$ & 15.3 & 0.178 & 0.064 & 0.094 & $<0.100$ & 0.055 & $<0.010$ & 0.643 \\
\hline SB4SULFA-02 & 21 & 1 & 1 & 15 & 5.57 & $<0.010$ & 0.415 & $<0.010$ & 0.130 & $<0.010$ & 1.36 & $<0.010$ & 0.059 & $<0.010$ & 15.4 & 0.178 & 0.071 & 0.096 & $<0.100$ & 0.057 & $<0.010$ & 0.639 \\
\hline LRM(5) & & 1 & 1 & 20 & 5.32 & $<0.010$ & 0.415 & $<0.010$ & 0.125 & $<0.010$ & 1.33 & $<0.010$ & 0.057 & $<0.010$ & 15.3 & 0.135 & 0.066 & 0.078 & $<0.100$ & 0.056 & $<0.010$ & 0.604 \\
\hline Batch 1 & HLM113 & 1 & 1 & 21 & 5.29 & $<0.010$ & 0.394 & $<0.010$ & 0.126 & $<0.010$ & 1.34 & $<0.010$ & 0.056 & $<0.010$ & 15.4 & 0.131 & 0.067 & 0.090 & $<0.100$ & 0.056 & $<0.010$ & 0.650 \\
\hline Ustd & tdLM113 & 1 & 1 & 22 & 4.96 & $<0.010$ & 0.392 & $<0.010$ & 0.120 & $<0.010$ & 1.28 & $<0.010$ & 0.053 & $<0.010$ & 15.5 & 0.110 & 0.052 & 0.101 & $<0.100$ & 0.052 & $<0.010$ & 0.600 \\
\hline Batch 1 & 1 & 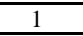 & I & 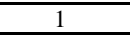 & 4.91 & $<0.010$ & 0.388 & $<0.010$ & 0.113 & $<0.010$ & 1.27 & $<0.010$ & 0.049 & $<0.010$ & 15.2 & 0.118 & 0.051 & 0.071 & $<0.100$ & 0.048 & $<0.010$ & 0.575 \\
\hline Ustd & UstaLMILL & 1 & 2 & 2 & 5.33 & $<0.010$ & 0.403 & $<0.010$ & 0.122 & $<0.010$ & 1.35 & $<0.010$ & 0.053 & $<0.010$ & 15.7 & 0.122 & 0.067 & 0.070 & $<0.100$ & 0.054 & $<0.010$ & $\begin{array}{ll}0.644 \\
\end{array}$ \\
\hline LRM(3) & M10LM12 & 1 & 2 & 3 & 5.16 & $<0.010$ & 0.413 & $<0.010$ & 0.135 & $<0.010$ & 1.26 & $<0.010$ & 0.054 & $<0.010$ & 14.7 & 0.145 & 0.064 & 0.080 & $<0.100$ & 0.053 & $<0.010$ & 0.632 \\
\hline SB4SULFA-03 & M05LM22 & 1 & 2 & 4 & 5.43 & $<0.010$ & 0.459 & $<0.010$ & 0.130 & $<0.010$ & 1.32 & $<0.010$ & 0.060 & $<0.010$ & 15.3 & 0.145 & 0.069 & 0.082 & $<0.100$ & 0.056 & $<0.010$ & $\begin{array}{ll}0.631 \\
\end{array}$ \\
\hline SB4SULFA-02 & 15LM22 & 1 & 2 & 5 & 5.25 & $<0.010$ & 0.409 & $<0.010$ & 0.141 & $<0.010$ & 1.3 & $<0.010$ & 0.059 & $<0.010$ & 15.2 & 0.128 & 0.067 & 0.085 & $<0.100$ & 0.056 & $<0.010$ & 0.640 \\
\hline LRM(1) & & 7 & 2 & s & 5.49 & $<0.010$ & 0.460 & $<0.010$ & 0.128 & $<0.010$ & 1.3 & $<0.010$ & 0.060 & $<0.010$ & 15.6 & 0.137 & 0.067 & 0.089 & $<0.100$ & 0.057 & $<0.010$ & $\begin{array}{l}0.616 \\
\end{array}$ \\
\hline SB4SULFA-02 & M12 & 1 & 2 & 7 & 5.32 & $<0.010$ & 0.374 & $<0.010$ & 0.136 & $<0.010$ & 1.3 & $<0.010$ & 0.068 & $<0.010$ & 15.5 & 0.149 & 0.072 & 0.083 & $<0.100$ & 0.061 & $<0.010$ & 0.704 \\
\hline SB4SULFA-05 & 112 & 1 & 2 & 0 & 5.12 & $<0.010$ & 0.418 & $<0.010$ & 0.135 & $<0.010$ & 1.2 & $<0.010$ & 0.068 & $<0.010$ & 15.3 & 0.126 & 0.065 & 0.094 & $<0.100$ & 0.058 & $<0.010$ & $\begin{array}{ll}0.668 \\
\end{array}$ \\
\hline LRM(5) & & 1 & 2 & 9 & 5.29 & $<0.010$ & 0.372 & $<0.010$ & 0.128 & $<0.010$ & 1.3 & $<0.010$ & 0.062 & $<0.010$ & 15.2 & 0.155 & 0.070 & 0.082 & $<0.100$ & 0.057 & $<0.010$ & 0.671 \\
\hline LRM(6) & M14LM12 & 1 & 2 & 10 & 5.10 & $<0.010$ & 0.416 & $<0.010$ & 0.122 & $<0.010$ & 1.28 & $<0.010$ & 0.060 & $<0.010$ & 15.1 & 0.125 & 0.067 & 0.064 & $<0.100$ & 0.053 & $<0.010$ & 0.624 \\
\hline Batch 1 & & 7 & 2 & 11 & 5.38 & $<0.010$ & 0.406 & $<0.010$ & 0.124 & $<0.010$ & 1.37 & $<0.010$ & 0.057 & $<0.010$ & 15.5 & 0.135 & 0.060 & 0.088 & $<0.100$ & 0.056 & $<0.010$ & 0.646 \\
\hline Ustd & UstdL & 1 & 2 & 12 & 5.33 & $<0.010$ & 0.395 & $<0.010$ & 0.136 & $<0.010$ & 1.3 & $<0.010$ & 0.064 & $<0.010$ & 15.6 & 0.122 & 0.073 & 0.083 & $<0.100$ & 0.062 & $<0.010$ & 0.685 \\
\hline LRM(1) & M12LM12 & 1 & 2 & 13 & 5.41 & $<0.010$ & 0.414 & $<0.010$ & 0.123 & $<0.010$ & 1.38 & $<0.010$ & 0.055 & $<0.010$ & 15.7 & 0.131 & 0.064 & 0.060 & $<0.100$ & 0.055 & $<0.010$ & 0.645 \\
\hline & & 1 & 2 & & 5.33 & $<0.0$ & 0.402 & $<0.010$ & 0.124 & $<0.010$ & 1.34 & $<0.010$ & 0.056 & $<0.010$ & 15.5 & 0.126 & 0.074 & 0.067 & $<0.100$ & 0.057 & $<0.010$ & 0.641 \\
\hline SB4SULFA-01 & M03LM22 & 1 & 2 & 15 & 4.94 & 0.040 & 0.701 & 0.035 & 0.049 & 0.020 & 0.122 & 0.030 & 0.515 & 1.58 & 10.7 & 0.424 & 0.026 & 0.177 & 0.114 & $<0.010$ & 0.028 & 0.051 \\
\hline SB4SULFA-01 & M03LM12 & 1 & 2 & 16 & 4.93 & 0.040 & 0.690 & 0.035 & 0.051 & 0.020 & 0.116 & 0.031 & 0.546 & 1.54 & 10.8 & 0.425 & 0.024 & 0.169 & 0.121 & $<0.010$ & 0.028 & 0.053 \\
\hline LRM(5) & & 1 & 2 & 17 & 4.94 & 0.038 & 0.698 & 0.033 & 0.050 & 0.019 & 0.118 & 0.028 & 0.528 & 1.57 & 10.9 & 0.418 & 0.027 & 0.155 & 0.116 & $<0.010$ & 0.027 & 0.053 \\
\hline SB4SULFA-05 & M13LM22 & 1 & 2 & 18 & 4.93 & 0.037 & 0.711 & 0.033 & 0.049 & 0.019 & 0.125 & 0.027 & 0.510 & 1.52 & 10.9 & 0.413 & 0.023 & 0.156 & 0.111 & $<0.010$ & 0.027 & 0.052 \\
\hline SB4SULFA-03 & & 1 & 2 & 19 & 4.90 & 0.041 & 0.675 & 0.041 & 0.053 & 0.020 & 0.110 & 0.031 & 0.594 & 1.57 & 10.8 & 0.429 & 0.027 & 0.185 & 0.132 & $<0.010$ & 0.031 & 0.055 \\
\hline LRM(3) & M10LM22 & 1 & 2 & 20 & 5.34 & 0.041 & 0.712 & 0.040 & 0.058 & 0.020 & 0.123 & 0.030 & 0.563 & 1.59 & 11.2 & 0.441 & 0.020 & 0.207 & 0.126 & $<0.010$ & 0.030 & 0.055 \\
\hline
\end{tabular}


Table B2. Measured Elemental Concentrations (in wt\%) for Samples Prepared Using Lithium Metaborate (continued)

\begin{tabular}{|c|c|c|c|c|c|c|c|c|c|c|c|c|c|c|c|c|c|c|c|c|c|c|}
\hline Glass ID & Laboratory ID & Block & \begin{tabular}{|l|} 
Sub- \\
Block
\end{tabular} & $\begin{array}{c}\text { Analytical } \\
\text { Sequence }\end{array}$ & Al & Ba & Ca & Ce & $\mathrm{Cr}$ & Cu & $\mathbf{K}$ & La & Mg & Mn & $\mathrm{Na}$ & $\mathbf{N i}$ & $\mathbf{P b}$ & $\mathbf{S}$ & Th & $\mathrm{Ti}$ & Zn & $\mathbf{Z r}$ \\
\hline Batch 1 & BCHLM123 & 1 & 2 & 21 & 5.37 & 0.037 & 0.704 & 0.037 & 0.054 & 0.019 & 0.123 & 0.027 & 0.525 & 1.59 & 11.2 & 0.442 & 0.027 & 0.165 & 0.118 & $<0.010$ & 0.027 & 0.052 \\
\hline Ustd & UstdLM123 & 1 & 2 & 22 & 4.91 & 0.037 & 0.676 & 0.037 & 0.050 & 0.019 & 0.111 & 0.027 & 0.555 & 1.58 & 10.8 & 0.431 & 0.027 & 0.196 & 0.127 & $<0.010$ & 0.029 & 0.054 \\
\hline Batch 1 & BCHLM211 & 2 & 1 & 1 & 4.82 & 0.039 & 0.722 & 0.039 & 0.057 & $\begin{array}{ll}0.021 \\
\end{array}$ & 0.132 & 0.030 & 0.526 & 1.54 & 10.0 & 0.422 & 0.023 & 0.186 & 0.117 & $<0.010$ & 0.037 & 0.061 \\
\hline Ustd & UstdLM211 & 2 & 1 & 2 & 4.89 & 0.041 & 0.680 & 0.040 & 0.060 & 0.018 & 0.115 & 0.031 & 0.576 & 1.56 & 10.4 & 0.423 & 0.029 & 0.200 & 0.127 & $<0.010$ & 0.031 & 0.064 \\
\hline SB4SULFA-10 & M06LM21 & 2 & 1 & 3 & 4.84 & 0.036 & 0.724 & 0.036 & 0.055 & 0.020 & 0.134 & 0.027 & 0.511 & 1.59 & 10.0 & 0.432 & 0.028 & 0.173 & 0.115 & $<0.010$ & 0.036 & 0.062 \\
\hline SB4SULFA-06 & M16LM21 & 2 & 1 & 4 & 4.92 & 0.035 & 0.693 & 0.037 & 0.054 & 0.016 & 0.118 & 0.026 & 0.517 & 1.54 & 10.6 & 0.429 & 0.031 & 0.196 & 0.120 & $<0.010$ & 0.028 & 0.060 \\
\hline SB4SULFA-04 & M02LM21 & 2 & 1 & 5 & 4.93 & 0.036 & 0.655 & 0.033 & 0.054 & 0.017 & 0.110 & 0.027 & 0.568 & 1.70 & 10.5 & 0.461 & 0.023 & 0.226 & 0.116 & $<0.010$ & 0.028 & 0.059 \\
\hline LRM(2) & M09LM21 & 2 & 1 & 6 & 4.97 & 0.035 & 0.710 & 0.033 & 0.052 & 0.018 & 0.129 & 0.026 & 0.536 & 1.62 & 10.8 & 0.434 & 0.023 & 0.220 & 0.111 & $<0.010$ & 0.029 & 0.057 \\
\hline SB4SULFA-07 & M04LM11 & 2 & 1 & 7 & 5.01 & 0.038 & 0.705 & 0.035 & 0.053 & 0.018 & 0.128 & 0.028 & 0.521 & 1.61 & 10.8 & 0.443 & 0.025 & 0.207 & 0.110 & $<0.010$ & 0.030 & 0.058 \\
\hline LRM(4) & M08LM11 & 2 & 1 & 9 & 4.92 & 0.044 & 0.712 & 0.039 & 0.055 & 0.021 & 0.120 & 0.033 & 0.553 & 1.55 & 10.7 & 0.418 & 0.025 & 0.229 & 0.125 & $<0.010$ & 0.030 & 0.055 \\
\hline $\begin{array}{l}\text { SB4SULFA-09 } \\
\end{array}$ & M11LM11 & 2 & 1 & 10 & 4.95 & 0.047 & 0.726 & 0.040 & 0.055 & 0.020 & 0.122 & 0.033 & 0.584 & 1.56 & 10.8 & 0.431 & 0.031 & 0.242 & 0.126 & $<0.010$ & 0.031 & 0.057 \\
\hline Batch 1 & BCHLM212 & 2 & 1 & 11 & 4.91 & 0.042 & 0.736 & 0.036 & 0.052 & 0.019 & 0.125 & 0.030 & 0.535 & 1.58 & 10.7 & 0.427 & 0.028 & 0.214 & 0.119 & $<0.010$ & 0.029 & 0.055 \\
\hline Ustd & $\begin{array}{l}\text { UstdLM212 } \\
\end{array}$ & 2 & 1 & 12 & 4.95 & 0.041 & 0.724 & 0.037 & 0.052 & 0.020 & 0.123 & 0.029 & 0.527 & 1.50 & 10.9 & 0.403 & 0.027 & 0.199 & 0.119 & $<0.010$ & 0.028 & 0.054 \\
\hline SB4SULFA-10 & M06LM11 & 2 & 1 & 13 & 3.95 & 0.035 & 0.712 & 0.033 & 0.046 & 0.018 & 0.123 & 0.027 & 0.548 & 1.69 & 8.92 & 0.471 & 0.021 & 0.173 & 0.119 & $<0.010$ & 0.028 & 0.059 \\
\hline LRM(2) & M09LM11 & 2 & 1 & 14 & 3.89 & 0.036 & 0.698 & 0.034 & 0.047 & 0.020 & 0.117 & 0.028 & 0.574 & 1.71 & 8.87 & 0.491 & 0.028 & 0.193 & 0.124 & $<0.010$ & 0.029 & 0.061 \\
\hline SB4SULFA-09 & M11LM21 & 2 & 1 & 15 & 3.97 & 0.040 & 0.717 & 0.036 & 0.050 & 0.018 & 0.122 & 0.030 & 0.560 & 1.64 & 9.09 & 0.447 & 0.026 & 0.161 & 0.125 & $<0.010$ & 0.031 & 0.062 \\
\hline SB4SULFA-06 & M16LM11 & 2 & 1 & 16 & 3.98 & 0.040 & 0.700 & 0.037 & 0.049 & 0.021 & 0.117 & 0.030 & 0.564 & 1.60 & 9.26 & 0.455 & 0.026 & 0.173 & 0.126 & $<0.010$ & 0.030 & 0.063 \\
\hline SB4SULFA-08 & M07LM21 & 2 & 1 & 17 & 4.83 & 0.034 & 0.655 & 0.030 & 0.051 & 0.017 & 0.114 & 0.028 & 0.554 & 1.67 & 8.77 & 0.447 & 0.029 & 0.178 & 0.123 & $<0.010$ & 0.027 & 0.060 \\
\hline LRM(4) & M08LM21 & 2 & 1 & 18 & 4.89 & 0.034 & 0.700 & 0.030 & 0.051 & 0.026 & 0.127 & 0.030 & 0.531 & 1.59 & 8.85 & 0.460 & 0.024 & 0.197 & 0.118 & $<0.010$ & 0.027 & 0.062 \\
\hline $\begin{array}{l}\text { SB4SULFA-07 } \\
\end{array}$ & M04LM21 & 2 & 1 & 19 & 4.97 & 0.036 & 0.691 & 0.032 & 0.052 & 0.026 & 0.125 & 0.031 & 0.520 & 1.55 & 9.06 & 0.442 & 0.022 & 0.177 & 0.118 & $<0.010$ & 0.028 & 0.062 \\
\hline Batch 1 & BCHLM213 & 2 & 1 & 21 & 4.85 & 0.033 & 0.699 & 0.032 & 0.048 & 0.021 & $\begin{array}{ll}0.121 \\
\end{array}$ & $\begin{array}{l}0.029 \\
\end{array}$ & 0.529 & 1.70 & 8.67 & 0.453 & 0.027 & 0.188 & 0.116 & $<0.010$ & 0.069 & 0.054 \\
\hline Ustd & UstdLM213 & 2 & 1 & 22 & 5.05 & 0.033 & 0.694 & 0.031 & 0.048 & 0.020 & 0.122 & 0.028 & 0.533 & 1.63 & 9.04 & 0.456 & 0.023 & 0.191 & 0.116 & $<0.010$ & 0.028 & 0.058 \\
\hline Batch 1 & BCHLM221 & 2 & 2 & 1 & 4.94 & 0.037 & 0.695 & 0.035 & 0.051 & 0.021 & 0.120 & 0.031 & 0.536 & 1.59 & 8.98 & 0.433 & 0.024 & 0.189 & 0.117 & $<0.010$ & 0.071 & 0.058 \\
\hline Ustd & UstdLM221 & 2 & 2 & 2 & 5.11 & 0.037 & 0.687 & 0.033 & 0.051 & 0.020 & 0.120 & 0.030 & 0.538 & 1.54 & 9.33 & 0.418 & 0.023 & 0.167 & 0.119 & $<0.010$ & 0.029 & 0.061 \\
\hline LRM(2) & M09LM12 & 2 & 2 & 3 & 4.85 & 0.033 & 0.737 & 0.032 & 0.046 & 0.021 & 0.124 & 0.028 & 0.525 & 1.67 & 8.74 & 0.455 & 0.028 & 0.202 & 0.118 & $<0.010$ & 0.029 & 0.063 \\
\hline SB4SULFA-04 & M02LM12 & 2 & 2 & 4 & 4.85 & 0.034 & 0.737 & 0.033 & 0.046 & 0.021 & 0.128 & 0.028 & 0.531 & 1.66 & 8.81 & 0.457 & 0.026 & 0.209 & 0.116 & $<0.010$ & 0.031 & 0.060 \\
\hline SB4SULFA-10 & M06LM12 & 2 & 2 & 5 & 4.91 & 0.037 & 0.734 & 0.035 & 0.050 & 0.021 & 0.122 & 0.031 & 0.534 & 1.59 & 9.01 & 0.425 & 0.026 & 0.205 & 0.119 & $<0.010$ & 0.032 & 0.064 \\
\hline LRM(2) & M09LM22 & 2 & 2 & 6 & 4.96 & 0.038 & 0.729 & 0.036 & 0.049 & 0.021 & 0.124 & 0.031 & 0.542 & 1.59 & 9.12 & 0.433 & 0.026 & 0.206 & 0.119 & $<0.010$ & 0.033 & 0.062 \\
\hline SB4SULFA-08 & M07LM12 & 2 & 2 & 7 & 4.95 & 0.035 & 0.664 & 0.030 & 0.051 & 0.018 & 0.112 & 0.028 & 0.555 & 1.67 & 8.83 & 0.445 & 0.025 & 0.202 & 0.120 & $<0.010$ & 0.026 & 0.052 \\
\hline SB4SULFA-07 & M04LM22 & 2 & 2 & 8 & 4.86 & 0.035 & 0.670 & 0.030 & 0.052 & 0.018 & 0.111 & 0.028 & 0.549 & 1.64 & 8.75 & 0.442 & 0.024 & 0.206 & 0.120 & $<0.010$ & 0.028 & 0.052 \\
\hline SB4SULFA-08 & M07LM22 & 2 & 2 & 9 & 4.86 & 0.039 & 0.665 & 0.033 & 0.056 & 0.018 & 0.108 & 0.030 & 0.561 & 1.60 & 8.84 & 0.432 & 0.024 & 0.216 & 0.121 & 0.012 & 0.030 & 0.055 \\
\hline LRM(4) & M08LM12 & 2 & 2 & 10 & 5.01 & 0.038 & 0.675 & 0.032 & 0.053 & 0.019 & 0.113 & 0.030 & 0.539 & 1.55 & 9.11 & 0.418 & 0.022 & 0.190 & 0.121 & $<0.010$ & 0.028 & 0.054 \\
\hline Batch 1 & BCHLM222 & 2 & 2 & 11 & 2.10 & $<0.010$ & 0.968 & $<0.010$ & 0.156 & $<0.010$ & $\begin{array}{l}2.64 \\
\end{array}$ & $<0.010$ & 0.662 & 2.13 & 8.70 & 0.793 & $<0.020$ & $<0.050$ & $<0.100$ & 0.521 & $<0.010$ & $<0.010$ \\
\hline Ustd & UstdLM222 & 2 & 2 & 12 & 2.11 & $<0.010$ & 0.704 & $<0.010$ & 0.168 & $<0.010$ & 2.68 & $<0.010$ & 0.744 & 2.06 & 8.92 & 0.769 & $<0.020$ & $<0.050$ & $<0.100$ & 0.583 & $<0.010$ & 0.003 \\
\hline LRM(4) & M08LM22 & 2 & 2 & 13 & 2.13 & $<0.010$ & 0.988 & $<0.010$ & 0.173 & $<0.010$ & 2.68 & $<0.010$ & 0.734 & 1.99 & 9.12 & 0.748 & $<0.020$ & $<0.050$ & $<0.100$ & 0.573 & $<0.010$ & $<0.010$ \\
\hline SB4SULFA-04 & M02LM22 & 2 & 2 & 14 & 2.11 & $<0.010$ & 0.974 & $<0.010$ & 0.155 & $<0.010$ & 2.64 & $<0.010$ & 0.652 & 2.11 & 8.77 & 0.778 & $<0.020$ & $<0.050$ & $<0.100$ & 0.528 & $<0.010$ & $<0.010$ \\
\hline $\begin{array}{l}\text { SB4SULFA-09 } \\
\end{array}$ & M11LM12 & 2 & 2 & 15 & 2.12 & $<0.010$ & 0.982 & $<0.010$ & 0.155 & $<0.010$ & 2.68 & $<0.010$ & 0.647 & 2.06 & 8.92 & 0.769 & $<0.020$ & $<0.050$ & $<0.100$ & 0.528 & $<0.010$ & $<0.010$ \\
\hline SB4SULFA-06 & M16LM22 & 2 & 2 & 16 & 2.12 & $<0.010$ & 0.996 & $<0.010$ & 0.150 & $<0.010$ & 2.70 & $<0.010$ & 0.621 & 1.97 & 9.03 & 0.732 & $<0.020$ & $<0.050$ & $<0.100$ & 0.512 & $<0.010$ & $<0.010$ \\
\hline $\begin{array}{l}\text { SB4SULFA-09 } \\
\end{array}$ & M11LM22 & 2 & 2 & 17 & 2.11 & $<0.010$ & 0.959 & $<0.010$ & 0.157 & $<0.010$ & 2.64 & $<0.010$ & 0.673 & 2.17 & 8.78 & 0.807 & $<0.020$ & $<0.050$ & $<0.100$ & 0.533 & $<0.010$ & $<0.010$ \\
\hline SB4SULFA-06 & M16LM12 & 2 & 2 & 18 & 2.09 & $<0.010$ & 0.967 & $<0.010$ & 0.154 & $<0.010$ & 2.60 & $<0.010$ & 0.661 & 2.17 & 8.76 & 0.809 & $<0.020$ & $<0.050$ & $<0.100$ & 0.525 & $<0.010$ & $<0.010$ \\
\hline
\end{tabular}


Table B2. Measured Elemental Concentrations (in wt\%) for Samples Prepared Using Lithium Metaborate (continued)

\begin{tabular}{|c|c|c|c|c|c|c|c|c|c|c|c|c|c|c|c|c|c|c|c|c|c|c|}
\hline Glass ID & Laboratory ID & Block & \begin{tabular}{|c|} 
Sub- \\
Block \\
\end{tabular} & $\begin{array}{c}\text { Analytical } \\
\text { Sequence }\end{array}$ & Al & Ba & Ca & Ce & $\mathrm{Cr}$ & $\mathbf{C u}$ & $\mathbf{K}$ & La & Mg & Mn & $\mathrm{Na}$ & $\mathbf{N i}$ & $\mathbf{P b}$ & $\mathrm{s}$ & Th & $\mathbf{T i}$ & $\mathbf{Z n}$ & $\mathrm{Zr}$ \\
\hline \begin{tabular}{|l|} 
SB4SULFA-07 \\
\end{tabular} & M04LM12 & 2 & 2 & 19 & 2.10 & $<0.010$ & 0.975 & $<0.010$ & 0.162 & $<0.010$ & 2.63 & $<0.010$ & 0.696 & 2.15 & 8.93 & 0.790 & $<0.020$ & $<0.050$ & $<0.100$ & 0.550 & $<0.010$ & $<0.010$ \\
\hline \begin{tabular}{|l|} 
SB4SULFA-10 \\
\end{tabular} & M06LM22 & 2 & 2 & 20 & 2.11 & $<0.010$ & 0.967 & $<0.010$ & 0.156 & $<0.010$ & 2.64 & $<0.010$ & 0.654 & 2.15 & $8.84 \quad$ & 0.804 & $<0.020$ & $<0.050$ & $<0.100$ & 0.526 & $<0.010$ & $<0.010$ \\
\hline Batch 1 & BCHLM223 & 2 & 2 & 21 & 2.10 & $<0.010$ & 0.960 & $<0.010$ & 0.158 & $<0.010$ & 2.65 & $<0.010$ & 0.672 & 2.07 & 8.89 & 0.761 & $<0.020$ & $<0.050$ & $<0.100$ & 0.523 & $<0.010$ & $<0.010$ \\
\hline Ustd & UstdLM223 & 2 & 2 & 22 & 2.12 & $<0.010$ & 0.972 & $<0.010$ & 0.154 & $<0.010$ & 2.66 & $<0.010$ & 0.658 & 2.08 & 8.99 & 0.772 & $<0.020$ & $<0.050$ & $<0.100$ & 0.518 & $<0.010$ & $<0.010$ \\
\hline
\end{tabular}


Table B3. Measured Elemental Concentrations (in wt\%) for Samples Prepared Using Peroxide Fusion

\begin{tabular}{|c|c|c|c|c|c|c|c|c|c|}
\hline Glass ID & PSAL ID & Block & Sub-Block & $\begin{array}{c}\text { Analytical } \\
\text { Sequence }\end{array}$ & B & $\mathbf{F e}$ & $\mathbf{L i}$ & Si & $\mathbf{U}$ \\
\hline Batch 1 & BCHPF111 & 1 & 1 & 1 & 2.35 & 8.70 & 2.03 & 22.4 & $<0.100$ \\
\hline Ustd & UstdPF111 & 1 & 1 & 2 & 2.97 & 8.45 & 1.45 & 19.9 & 1.84 \\
\hline SB4SULFA-03 & M05PF21 & 1 & 1 & 3 & 1.50 & 6.16 & 2.32 & 22.2 & 2.29 \\
\hline LRM(2) & M09PF21 & 1 & 1 & 4 & 2.27 & 0.77 & 0.152 & 22.9 & $<0.100$ \\
\hline LRM(4) & M08PF21 & 1 & 1 & 5 & $<0.100$ & $<0.100$ & 0.111 & 25.1 & $<0.100$ \\
\hline LRM(4) & M08PF11 & 1 & 1 & 6 & 4.09 & 1.38 & 0.194 & 24.5 & $<0.100$ \\
\hline $\operatorname{LRM}(2)$ & M09PF11 & 1 & 1 & 7 & 2.29 & 0.77 & 0.157 & 23.1 & $<0.100$ \\
\hline SB4SULFA-09 & M11PF21 & 1 & 1 & 8 & 2.59 & 5.72 & 2.20 & 20.7 & 2.17 \\
\hline SB4SULFA-08 & M07PF11 & 1 & 1 & 9 & 2.62 & 5.86 & 2.25 & 20.5 & 2.22 \\
\hline SB4SULFA-04 & M02PF11 & 1 & 1 & 10 & 1.53 & 5.87 & 2.23 & 21.6 & 2.19 \\
\hline Batch 1 & BCHPF112 & 1 & 1 & 11 & 2.34 & 8.43 & 1.97 & 22.1 & $<0.100$ \\
\hline Ustd & UstdPF112 & 1 & 1 & 12 & 2.71 & 7.88 & 1.42 & 19.1 & 1.75 \\
\hline SB4SULFA-04 & M02PF21 & 1 & 1 & 13 & 1.56 & 5.70 & 2.22 & 21.2 & 2.15 \\
\hline SB4SULFA-07 & M04PF11 & 1 & 1 & 14 & 2.59 & 5.84 & 2.20 & 20.7 & 2.20 \\
\hline SB4SULFA-09 & M11PF11 & 1 & 1 & 15 & 2.61 & 5.78 & 2.19 & 20.7 & 2.22 \\
\hline SB4SULFA-10 & M06PF11 & 1 & 1 & 16 & 2.66 & 6.01 & 2.21 & 20.9 & 2.29 \\
\hline SB4SULFA-10 & M06PF21 & 1 & 1 & 17 & 2.61 & 5.73 & 2.22 & 20.7 & 2.22 \\
\hline SB4SULFA-08 & M07PF21 & 1 & 1 & 18 & 2.54 & 5.80 & 2.20 & 20.5 & 2.26 \\
\hline SB4SULFA-03 & M05PF11 & 1 & 1 & 19 & 1.46 & 5.63 & 2.22 & 21.1 & 2.26 \\
\hline SB4SULFA-07 & M04PF21 & 1 & 1 & 20 & 2.54 & 5.68 & 2.21 & 20.5 & 2.23 \\
\hline Batch 1 & BCHPF113 & 1 & 1 & 21 & 2.34 & 8.32 & 1.97 & 21.8 & $<0.100$ \\
\hline Ustd & Ustdpf113 & 1 & 1 & 22 & 2.73 & 7.86 & 1.42 & 19.0 & 1.80 \\
\hline Batch 1 & BCHPF121 & 1 & 2 & 1 & 2.65 & 8.95 & 2.02 & 23.1 & $<0.100$ \\
\hline Ustd & UstdPF121 & 1 & 2 & 2 & 2.94 & 8.56 & 1.43 & 20.4 & 1.87 \\
\hline SB4SULFA-07 & M04PF22 & 1 & 2 & 3 & 2.70 & 6.06 & 2.26 & 21.4 & 2.24 \\
\hline LRM(4) & M08PF22 & 1 & 2 & 4 & $<0.100$ & $<0.100$ & 0.111 & 24.8 & $<0.100$ \\
\hline SB4SULFA-10 & M06PF12 & 1 & 2 & 5 & 2.75 & 6.40 & 2.26 & 21.8 & 2.37 \\
\hline $\operatorname{LRM}(2)$ & M09PF12 & 1 & 2 & 6 & 2.38 & 0.88 & 0.142 & 24.3 & $<0.100$ \\
\hline SB4SULFA-07 & M04PF12 & 1 & 2 & 7 & 2.70 & 6.25 & 2.26 & 21.6 & 2.31 \\
\hline SB4SULFA-04 & M02PF22 & 1 & 2 & 8 & 1.54 & 6.04 & 2.27 & 22.2 & 2.24 \\
\hline SB4SULFA-10 & M06PF22 & 1 & 2 & 9 & 2.69 & 6.15 & 2.27 & 21.6 & 2.30 \\
\hline SB4SULFA-08 & M07PF22 & 1 & 2 & 10 & 2.65 & 6.07 & 2.26 & 21.3 & 2.27 \\
\hline Batch 1 & BCHPF122 & 1 & 2 & 11 & 2.45 & 8.98 & 2.01 & 23.1 & $<0.100$ \\
\hline Ustd & UstdPF122 & 1 & 2 & 12 & 2.81 & 8.43 & 1.44 & 20.4 & 1.86 \\
\hline SB4SULFA-09 & M11PF12 & 1 & 2 & 13 & 2.80 & 6.24 & 2.24 & 21.6 & 2.30 \\
\hline LRM(4) & M08PF12 & 1 & 2 & 14 & 4.34 & 1.49 & 0.180 & 24.2 & $<0.100$ \\
\hline SB4SULFA-04 & M02PF12 & 1 & 2 & 15 & 1.60 & 6.14 & 2.27 & 22.3 & 2.32 \\
\hline SB4SULFA-03 & M05PF12 & 1 & 2 & 16 & 1.54 & 6.10 & 2.28 & 22.2 & 2.30 \\
\hline LRM(2) & M09PF22 & 1 & 2 & 17 & 2.33 & 0.80 & 0.135 & 23.8 & $<0.100$ \\
\hline SB4SULFA-03 & M05PF22 & 1 & 2 & 18 & 1.55 & 6.18 & 2.33 & 22.6 & 2.34 \\
\hline SB4SULFA-08 & M07PF12 & 1 & 2 & 19 & 2.67 & 6.25 & 2.29 & 21.6 & 2.35 \\
\hline SB4SULFA-09 & M11PF22 & 1 & 2 & 20 & 2.69 & 6.06 & 2.25 & 21.6 & 2.29 \\
\hline Batch 1 & BCHPF123 & 1 & 2 & 21 & 2.43 & 8.77 & 2.01 & 22.9 & $<0.100$ \\
\hline Ustd & UstdPF123 & 1 & 2 & 22 & 2.79 & 8.45 & 1.43 & 20.1 & 1.88 \\
\hline Batch 1 & BCHPF211 & 2 & 1 & 1 & 2.66 & 9.15 & 2.02 & 23.0 & $<0.100$ \\
\hline Ustd & UstdPF211 & 2 & 1 & 2 & 2.96 & 8.74 & 1.45 & 20.1 & 1.89 \\
\hline SB4SULFA-06 & M16PF11 & 2 & 1 & 3 & 2.84 & 6.52 & 2.31 & 22.2 & 2.43 \\
\hline SB4SULFA-05 & M13PF11 & 2 & 1 & 4 & 1.63 & 6.27 & 2.31 & 22.4 & 2.33 \\
\hline LRM $(1)$ & M12PF21 & 2 & 1 & 5 & 2.50 & 1.02 & 0.133 & 25.0 & $<0.100$ \\
\hline LRM(3) & M10PF21 & 2 & 1 & 6 & 2.48 & 0.93 & 0.132 & 25.1 & $<0.100$ \\
\hline LRM(3) & M10PF11 & 2 & 1 & 7 & 2.47 & 0.92 & 0.133 & 25.0 & $<0.100$ \\
\hline LRM(5) & M01PF21 & 2 & 1 & 8 & 2.49 & 1.00 & 0.150 & 25.2 & $<0.100$ \\
\hline SB4SULFA-01 & M03PF11 & 2 & 1 & 9 & 1.53 & 6.57 & 2.25 & 22.2 & 2.33 \\
\hline LRM(6) & M14PF21 & 2 & 1 & 10 & 2.45 & 1.04 & 0.164 & 25.2 & $<0.100$ \\
\hline Batch 1 & BCHPF212 & 2 & 1 & 11 & 2.41 & 8.87 & 2.02 & 22.8 & $<0.100$ \\
\hline Ustd & UstdPF212 & 2 & 1 & 12 & 2.82 & 8.62 & 1.44 & 20.1 & 1.90 \\
\hline SB4SULFA-05 & M13PF21 & 2 & 1 & 13 & 1.62 & 6.15 & 2.27 & 22.8 & 2.37 \\
\hline SB4SULFA-01 & M03PF21 & 2 & 1 & 14 & 1.54 & 6.60 & 2.24 & 22.1 & 2.37 \\
\hline SB4SULFA-06 & M16PF21 & 2 & 1 & 15 & 2.76 & 6.62 & 2.31 & 22.3 & 2.41 \\
\hline LRM(5) & M01PF11 & 2 & 1 & 16 & 2.47 & 1.10 & 0.180 & 25.3 & $<0.100$ \\
\hline SB4SULFA-02 & M15PF21 & 2 & 1 & 17 & 1.59 & 6.81 & 2.34 & 22.6 & 2.38 \\
\hline LRM $(1)$ & M12PF11 & 2 & 1 & 18 & 2.44 & 1.01 & 0.131 & 25.2 & $<0.100$ \\
\hline SB4SULFA-02 & M15PF11 & 2 & 1 & 19 & 1.50 & 7.02 & 2.27 & 21.8 & 2.37 \\
\hline LRM(6) & M14PF11 & 2 & 1 & 20 & 2.42 & 0.95 & 0.143 & 24.8 & $<0.100$ \\
\hline Batch 1 & BCHPF213 & 2 & 1 & 21 & 2.41 & 9.01 & 2.03 & 22.9 & $<0.100$ \\
\hline
\end{tabular}


Table B3. Measured Elemental Concentrations (in wt\%) for Samples Prepared Using Peroxide Fusion (continued)

\begin{tabular}{||c|c|c|c|c|c|c|c|c|c||}
\hline Glass ID & PSAL ID & Block & Sub-Block & $\begin{array}{c}\text { Analytical } \\
\text { Sequence }\end{array}$ & $\mathbf{B}$ & $\mathbf{F e}$ & $\mathbf{L i}$ & $\mathbf{S i}$ & $\mathbf{U}$ \\
\hline Ustd & UstdPF213 & 2 & 1 & 22 & 2.81 & 8.66 & 1.46 & 20.2 & 1.93 \\
\hline Batch 1 & BCHPF221 & 2 & 2 & 1 & 2.56 & 8.93 & 2.01 & 22.9 & $<0.100$ \\
\hline Ustd & UstdPF221 & 2 & 2 & 2 & 2.91 & 8.72 & 1.44 & 20.2 & 1.84 \\
\hline SB4SULFA-05 & M13PF22 & 2 & 2 & 3 & 1.58 & 6.23 & 2.27 & 22.5 & 2.33 \\
\hline LRM(6) & M14PF12 & 2 & 2 & 4 & 2.46 & 0.90 & 0.140 & 24.9 & $<0.100$ \\
\hline SB4SULFA-05 & M13PF12 & 2 & 2 & 5 & 1.54 & 6.22 & 2.30 & 22.4 & 2.31 \\
\hline SB4SULFA-06 & M16PF22 & 2 & 2 & 6 & 2.76 & 6.69 & 2.31 & 22.6 & 2.42 \\
\hline SB4SULFA-06 & M16PF12 & 2 & 2 & 7 & 2.78 & 6.64 & 2.31 & 22.4 & 2.41 \\
\hline LRM(5) & M01PF12 & 2 & 2 & 8 & 2.49 & 1.03 & 0.173 & 25.6 & $<0.100$ \\
\hline LRM(5) & M01PF22 & 2 & 2 & 9 & 2.43 & 0.91 & 0.145 & 25.2 & $<0.100$ \\
\hline LRM(3) & M10PF22 & 2 & 2 & 10 & 2.43 & 0.84 & 0.128 & 25.2 & $<0.100$ \\
\hline Batch 1 & BCHPF222 & 2 & 2 & 11 & 2.42 & 9.07 & 2.02 & 23.1 & $<0.100$ \\
\hline Ustd & UstdPF222 & 2 & 2 & 12 & 2.81 & 8.69 & 1.45 & 20.2 & 1.90 \\
\hline LRM(3) & M10PF12 & 2 & 2 & 13 & 2.49 & 0.84 & 0.129 & 25.2 & $<0.100$ \\
\hline LRM(1) & M12PF22 & 2 & 2 & 14 & 2.46 & 0.93 & 0.129 & 25.2 & $<0.100$ \\
\hline SB4SULFA-02 & M15PF12 & 2 & 2 & 15 & 1.55 & 7.29 & 2.28 & 22.3 & 2.39 \\
\hline SB4SULFA-01 & M03PF12 & 2 & 2 & 16 & 1.52 & 6.76 & 2.27 & 22.7 & 2.39 \\
\hline LRM(6) & M14PF22 & 2 & 2 & 17 & 2.45 & 0.99 & 0.162 & 25.6 & $<0.100$ \\
\hline SB4SULFA-01 & M03PF22 & 2 & 2 & 18 & 1.49 & 6.60 & 2.25 & 22.3 & 2.29 \\
\hline SB4SULFA-02 & M15PF22 & 2 & 2 & 19 & 1.53 & 6.92 & 2.33 & 23.0 & 2.33 \\
\hline LRM(1) & M12PF12 & 2 & 2 & 20 & 2.44 & 0.95 & 0.125 & 25.4 & $<0.100$ \\
\hline Batch 1 & BCHPF223 & 2 & 2 & 21 & 2.41 & 9.24 & 2.04 & 23.2 & $<0.100$ \\
\hline Ustd & UstdPF223 & 2 & 2 & 22 & 2.84 & 8.96 & 1.46 & 20.4 & 1.86 \\
\hline
\end{tabular}


WSRC-STI-2006-00038

Revision 0

Appendix B

Table B4. Average Measured and Bias-Corrected Chemical Compositions Versus Targeted Compositions by Oxide by SB4 Sulfate Study Glass

\author{
(100 -Batch 1; 200 -U std; 300 - LRM)
}

\begin{tabular}{|c|c|c|c|c|c|c|c|c|c|}
\hline Glass ID & Glass \# & Oxide & $\begin{array}{c}\text { Measured } \\
\text { (wt\%) }\end{array}$ & $\begin{array}{c}\text { Measured } \\
\text { Bias-Corrected } \\
(w t \%)\end{array}$ & $\begin{array}{c}\text { Targeted } \\
\text { (wt\%) }\end{array}$ & $\begin{array}{c}\text { Diff of } \\
\text { Measured }\end{array}$ & $\begin{array}{c}\text { Diff of } \\
\text { Meas. bc }\end{array}$ & $\begin{array}{l}\text { \% Diff of } \\
\text { Measured }\end{array}$ & $\begin{array}{l}\text { \% Diff of } \\
\text { Meas. bc }\end{array}$ \\
\hline SB4SULFA-01 & 1 & $\mathrm{Al}_{2} \mathrm{O}_{3}$ & 9.3247 & 9.5445 & 8.9300 & 0.3947 & 0.6145 & $4.4 \%$ & $6.9 \%$ \\
\hline SB4SULFA-01 & 1 & $\mathrm{~B}_{2} \mathrm{O}_{3}$ & 4.8942 & 4.7696 & 4.9500 & -0.0558 & -0.1804 & $-1.1 \%$ & $-3.6 \%$ \\
\hline SB4SULFA-01 & 1 & $\mathrm{BaO}$ & 0.0433 & 0.0461 & 0.0500 & -0.0067 & -0.0039 & $-13.5 \%$ & $-7.7 \%$ \\
\hline SB4SULFA-01 & 1 & $\mathrm{CaO}$ & 0.9794 & 0.9576 & 0.9000 & 0.0794 & 0.0576 & $8.8 \%$ & $6.4 \%$ \\
\hline SB4SULFA-01 & 1 & $\mathrm{Ce}_{2} \mathrm{O}_{3}$ & 0.0398 & 0.0398 & 0.0600 & -0.0202 & -0.0202 & $-33.6 \%$ & $-33.6 \%$ \\
\hline SB4SULFA-01 & 1 & $\mathrm{Cr}_{2} \mathrm{O}_{3}$ & 0.0727 & 0.0777 & 0.0800 & -0.0073 & -0.0023 & $-9.1 \%$ & $-2.8 \%$ \\
\hline SB4SULFA-01 & 1 & $\mathrm{CuO}$ & 0.0244 & 0.0237 & 0.0200 & 0.0044 & 0.0037 & $22.1 \%$ & $18.5 \%$ \\
\hline SB4SULFA-01 & 1 & $\mathrm{Fe}_{2} \mathrm{O}_{3}$ & 9.4825 & 9.4144 & 10.0400 & -0.5575 & -0.6256 & $-5.6 \%$ & $-6.2 \%$ \\
\hline SB4SULFA-01 & 1 & $\mathrm{~K}_{2} \mathrm{O}$ & 0.1449 & 0.1362 & 0.1200 & 0.0249 & 0.0162 & $20.7 \%$ & $13.5 \%$ \\
\hline SB4SULFA-01 & 1 & $\mathrm{La}_{2} \mathrm{O}_{3}$ & 0.0340 & 0.0340 & 0.0400 & -0.0060 & -0.0060 & $-15.0 \%$ & $-15.0 \%$ \\
\hline SB4SULFA-01 & 1 & $\mathrm{Li}_{2} \mathrm{O}$ & 4.8494 & 4.9306 & 4.9500 & -0.1006 & -0.0194 & $-2.0 \%$ & $-0.4 \%$ \\
\hline SB4SULFA-01 & 1 & $\mathrm{MgO}$ & 0.8702 & 0.9080 & 0.9600 & -0.0898 & -0.0520 & $-9.4 \%$ & $-5.4 \%$ \\
\hline SB4SULFA-01 & 1 & $\mathrm{MnO}$ & 2.0046 & 2.1612 & 2.0700 & -0.0654 & 0.0912 & $-3.2 \%$ & $4.4 \%$ \\
\hline SB4SULFA-01 & 1 & $\mathrm{Na}_{2} \mathrm{O}$ & 14.5921 & 13.8531 & 13.9700 & 0.6221 & -0.1169 & $4.5 \%$ & $-0.8 \%$ \\
\hline SB4SULFA-01 & 1 & $\mathrm{NiO}$ & 0.5345 & 0.5976 & 0.5900 & -0.0556 & 0.0076 & $-9.4 \%$ & $1.3 \%$ \\
\hline SB4SULFA-01 & 1 & $\mathrm{PbO}$ & 0.0269 & 0.0269 & 0.0400 & -0.0131 & -0.0131 & $-32.7 \%$ & $-32.7 \%$ \\
\hline SB4SULFA-01 & 1 & $\mathrm{SO}_{4}$ & 0.4921 & 0.4921 & 0.6000 & -0.1079 & -0.1079 & $-18.0 \%$ & $-18.0 \%$ \\
\hline SB4SULFA-01 & 1 & $\mathrm{SiO}_{2}$ & 47.7599 & 48.7808 & 48.5600 & -0.8001 & 0.2208 & $-1.6 \%$ & $0.5 \%$ \\
\hline SB4SULFA-01 & 1 & $\mathrm{ThO}_{2}$ & 0.1314 & 0.1314 & 0.0200 & 0.1114 & 0.1114 & $557.1 \%$ & $557.1 \%$ \\
\hline SB4SULFA-01 & 1 & $\mathrm{TiO}_{2}$ & 0.0083 & 0.0088 & 0.0100 & -0.0017 & -0.0012 & $-16.6 \%$ & $-11.8 \%$ \\
\hline SB4SULFA-01 & 1 & $\mathrm{U}_{3} \mathrm{O}_{8}$ & 2.7652 & 2.9908 & 2.9100 & -0.1448 & 0.0808 & $-5.0 \%$ & $2.8 \%$ \\
\hline SB4SULFA-01 & 1 & $\mathrm{ZnO}$ & 0.0342 & 0.0342 & 0.0400 & -0.0058 & -0.0058 & $-14.4 \%$ & $-14.4 \%$ \\
\hline SB4SULFA-01 & 1 & $\mathrm{ZrO}_{2}$ & 0.0706 & 0.0706 & 0.0900 & -0.0194 & -0.0194 & $-21.6 \%$ & $-21.6 \%$ \\
\hline SB4SULFA-01 & 1 & Sum & 99.1794 & 100.0299 & 100.0000 & -0.8206 & 0.0299 & $-0.8 \%$ & $0.0 \%$ \\
\hline SB4SULFA-02 & 2 & $\mathrm{Al}_{2} \mathrm{O}_{3}$ & 9.6931 & 9.9216 & 8.9200 & 0.7731 & 1.0016 & $8.7 \%$ & $11.2 \%$ \\
\hline SB4SULFA-02 & 2 & $\mathrm{~B}_{2} \mathrm{O}_{3}$ & 4.9667 & 4.8405 & 4.9500 & 0.0167 & -0.1095 & $0.3 \%$ & $-2.2 \%$ \\
\hline SB4SULFA-02 & 2 & $\mathrm{BaO}$ & 0.0435 & 0.0464 & 0.0500 & -0.0065 & -0.0036 & $-12.9 \%$ & $-7.2 \%$ \\
\hline SB4SULFA-02 & 2 & $\mathrm{CaO}$ & 0.9679 & 0.9463 & 0.9000 & 0.0679 & 0.0463 & $7.5 \%$ & $5.1 \%$ \\
\hline SB4SULFA-02 & 2 & $\mathrm{Ce}_{2} \mathrm{O}_{3}$ & 0.0454 & 0.0454 & 0.0600 & -0.0146 & -0.0146 & $-24.4 \%$ & $-24.4 \%$ \\
\hline SB4SULFA-02 & 2 & $\mathrm{Cr}_{2} \mathrm{O}_{3}$ & 0.0786 & 0.0839 & 0.0800 & -0.0014 & 0.0039 & $-1.8 \%$ & $4.9 \%$ \\
\hline SB4SULFA-02 & 2 & $\mathrm{CuO}$ & 0.0244 & 0.0237 & 0.0200 & 0.0044 & 0.0037 & $22.1 \%$ & $18.5 \%$ \\
\hline SB4SULFA-02 & 2 & $\mathrm{Fe}_{2} \mathrm{O}_{3}$ & 10.0222 & 9.9500 & 10.0300 & -0.0078 & -0.0800 & $-0.1 \%$ & $-0.8 \%$ \\
\hline SB4SULFA-02 & 2 & $\mathrm{~K}_{2} \mathrm{O}$ & 0.1406 & 0.1322 & 0.1200 & 0.0206 & 0.0122 & $17.2 \%$ & $10.2 \%$ \\
\hline SB4SULFA-02 & 2 & $\mathrm{La}_{2} \mathrm{O}_{3}$ & 0.0337 & 0.0337 & 0.0400 & -0.0063 & -0.0063 & $-15.7 \%$ & $-15.7 \%$ \\
\hline SB4SULFA-02 & 2 & $\mathrm{Li}_{2} \mathrm{O}$ & 4.9624 & 5.0456 & 4.9500 & 0.0124 & 0.0956 & $0.3 \%$ & $1.9 \%$ \\
\hline SB4SULFA-02 & 2 & $\mathrm{MgO}$ & 0.9274 & 0.9669 & 0.9600 & -0.0326 & 0.0069 & $-3.4 \%$ & $0.7 \%$ \\
\hline SB4SULFA-02 & 2 & $\mathrm{MnO}$ & 2.0433 & 2.2032 & 2.0700 & -0.0267 & 0.1332 & $-1.3 \%$ & $6.4 \%$ \\
\hline SB4SULFA-02 & 2 & $\mathrm{Na}_{2} \mathrm{O}$ & 14.8280 & 14.0772 & 13.9600 & 0.8680 & 0.1172 & $6.2 \%$ & $0.8 \%$ \\
\hline SB4SULFA-02 & 2 & $\mathrm{NiO}$ & 0.5545 & 0.6201 & 0.5900 & -0.0355 & 0.0301 & $-6.0 \%$ & $5.1 \%$ \\
\hline SB4SULFA-02 & 2 & $\mathrm{PbO}$ & 0.0272 & 0.0272 & 0.0400 & -0.0128 & -0.0128 & $-32.0 \%$ & $-32.0 \%$ \\
\hline SB4SULFA-02 & 2 & $\mathrm{SO}_{4}$ & 0.5640 & 0.5640 & 0.6500 & -0.0860 & -0.0860 & $-13.2 \%$ & $-13.2 \%$ \\
\hline SB4SULFA-02 & 2 & $\mathrm{SiO}_{2}$ & 47.9738 & 48.9989 & 48.5400 & -0.5662 & 0.4589 & $-1.2 \%$ & $0.9 \%$ \\
\hline SB4SULFA-02 & 2 & $\mathrm{ThO}_{2}$ & 0.1431 & 0.1431 & 0.0200 & 0.1231 & 0.1231 & $615.5 \%$ & $615.5 \%$ \\
\hline SB4SULFA-02 & 2 & $\mathrm{TiO}_{2}$ & 0.0083 & 0.0088 & 0.0100 & -0.0017 & -0.0012 & $-16.6 \%$ & $-11.8 \%$ \\
\hline SB4SULFA-02 & 2 & $\mathrm{U}_{3} \mathrm{O}_{8}$ & 2.7918 & 3.0194 & 2.9100 & -0.1182 & 0.1094 & $-4.1 \%$ & $3.8 \%$ \\
\hline SB4SULFA-02 & 2 & $\mathrm{ZnO}$ & 0.0364 & 0.0364 & 0.0400 & -0.0036 & -0.0036 & $-9.0 \%$ & $-9.0 \%$ \\
\hline SB4SULFA-02 & 2 & $\mathrm{ZrO}_{2}$ & 0.0729 & 0.0729 & 0.0900 & -0.0171 & -0.0171 & $-19.0 \%$ & $-19.0 \%$ \\
\hline SB4SULFA-02 & 2 & Sum & 100.9494 & 101.8074 & 100.0000 & 0.9494 & 1.8074 & $0.9 \%$ & $1.8 \%$ \\
\hline SB4SULFA-03 & 3 & $\mathrm{Al}_{2} \mathrm{O}_{3}$ & 9.1971 & 9.4140 & 8.9200 & 0.2771 & 0.4940 & $3.1 \%$ & $5.5 \%$ \\
\hline SB4SULFA-03 & 3 & $\mathrm{~B}_{2} \mathrm{O}_{3}$ & 4.8701 & 4.8494 & 4.9500 & -0.0799 & -0.1006 & $-1.6 \%$ & $-2.0 \%$ \\
\hline SB4SULFA-03 & 3 & $\mathrm{BaO}$ & 0.0421 & 0.0449 & 0.0500 & -0.0079 & -0.0051 & $-15.7 \%$ & $-10.2 \%$ \\
\hline SB4SULFA-03 & 3 & $\mathrm{CaO}$ & 0.9861 & 0.9641 & 0.9000 & 0.0861 & 0.0641 & $9.6 \%$ & $7.1 \%$ \\
\hline SB4SULFA-03 & 3 & $\mathrm{Ce}_{2} \mathrm{O}_{3}$ & 0.0445 & 0.0445 & 0.0600 & -0.0155 & -0.0155 & $-25.8 \%$ & $-25.8 \%$ \\
\hline SB4SULFA-03 & 3 & $\mathrm{Cr}_{2} \mathrm{O}_{3}$ & 0.0826 & 0.0882 & 0.0800 & 0.0026 & 0.0082 & $3.2 \%$ & $10.3 \%$ \\
\hline SB4SULFA-03 & 3 & $\mathrm{CuO}$ & 0.0235 & 0.0228 & 0.0200 & 0.0035 & 0.0028 & $17.4 \%$ & $13.9 \%$ \\
\hline SB4SULFA-03 & 3 & $\mathrm{Fe}_{2} \mathrm{O}_{3}$ & 8.6032 & 8.8896 & 10.0300 & -1.4268 & -1.1404 & $-14.2 \%$ & $-11.4 \%$ \\
\hline SB4SULFA-03 & 3 & $\mathrm{~K}_{2} \mathrm{O}$ & 0.1503 & 0.1413 & 0.1200 & 0.0303 & 0.0213 & $25.2 \%$ & $17.7 \%$ \\
\hline SB4SULFA-03 & 3 & $\mathrm{La}_{2} \mathrm{O}_{3}$ & 0.0334 & 0.0334 & 0.0400 & -0.0066 & -0.0066 & $-16.4 \%$ & $-16.4 \%$ \\
\hline SB4SULFA-03 & 3 & $\mathrm{Li}_{2} \mathrm{O}$ & 4.9248 & 5.0614 & 4.9500 & -0.0252 & 0.1114 & $-0.5 \%$ & $2.3 \%$ \\
\hline SB4SULFA-03 & 3 & $\mathrm{MgO}$ & 0.8830 & 0.9206 & 0.9600 & -0.0770 & -0.0394 & $-8.0 \%$ & $-4.1 \%$ \\
\hline SB4SULFA-03 & 3 & $\mathrm{MnO}$ & 2.0110 & 2.1685 & 2.0700 & -0.0590 & 0.0985 & $-2.8 \%$ & $4.8 \%$ \\
\hline SB4SULFA-03 & 3 & $\mathrm{Na}_{2} \mathrm{O}$ & 13.8170 & 13.1173 & 13.9600 & -0.1430 & -0.8427 & $-1.0 \%$ & $-6.0 \%$ \\
\hline SB4SULFA-03 & 3 & $\mathrm{NiO}$ & 0.5427 & 0.6070 & 0.5900 & -0.0473 & 0.0170 & $-8.0 \%$ & $2.9 \%$ \\
\hline SB4SULFA-03 & 3 & $\mathrm{PbO}$ & 0.0299 & 0.0299 & 0.0400 & -0.0101 & -0.0101 & $-25.3 \%$ & $-25.3 \%$ \\
\hline
\end{tabular}


WSRC-STI-2006-00038

Revision 0

Appendix B

Table B4. Average Measured and Bias-Corrected Chemical Compositions Versus Targeted Compositions by Oxide by SB4 Sulfate Study Glass (continued)

(100 -Batch 1; 200 -U std; 300 - LRM)

\begin{tabular}{|c|c|c|c|c|c|c|c|c|c|}
\hline Glass ID & Glass \# & Oxide & $\begin{array}{c}\text { Measured } \\
\text { (wt\%) }\end{array}$ & $\begin{array}{c}\text { Measured } \\
\text { Bias-Corrected } \\
\text { (wt \%) }\end{array}$ & $\begin{array}{c}\text { Targeted } \\
\text { (wt } \%)\end{array}$ & $\begin{array}{c}\text { Diff of } \\
\text { Measured }\end{array}$ & $\begin{array}{c}\text { Diff of } \\
\text { Meas. bc }\end{array}$ & $\begin{array}{l}\text { \% Diff of } \\
\text { Measured }\end{array}$ & $\begin{array}{l}\text { \% Diff of } \\
\text { Meas. bc }\end{array}$ \\
\hline SB4SULFA-03 & 3 & $\mathrm{SO}_{4}$ & 0.5655 & 0.5655 & 0.7000 & -0.1345 & -0.1345 & $-19.2 \%$ & $-19.2 \%$ \\
\hline SB4SULFA-03 & 3 & $\mathrm{SiO}_{2}$ & 47.1181 & 49.0183 & 48.5200 & -1.4019 & 0.4983 & $-2.9 \%$ & $1.0 \%$ \\
\hline SB4SULFA-03 & 3 & $\mathrm{ThO}_{2}$ & 0.1363 & 0.1363 & 0.0200 & 0.1163 & 0.1163 & $581.3 \%$ & $581.3 \%$ \\
\hline SB4SULFA-03 & 3 & $\mathrm{TiO}_{2}$ & 0.0083 & 0.0088 & 0.0100 & -0.0017 & -0.0012 & $-16.6 \%$ & $-11.8 \%$ \\
\hline SB4SULFA-03 & 3 & $\mathrm{U}_{3} \mathrm{O}_{8}$ & 2.7092 & 3.0158 & 2.9100 & -0.2008 & 0.1058 & $-6.9 \%$ & $3.6 \%$ \\
\hline SB4SULFA-03 & 3 & $\mathrm{ZnO}$ & 0.0411 & 0.0411 & 0.0400 & 0.0011 & 0.0011 & $2.7 \%$ & $2.7 \%$ \\
\hline SB4SULFA-03 & 3 & $\mathrm{ZrO}_{2}$ & 0.0834 & 0.0834 & 0.0900 & -0.0066 & -0.0066 & $-7.3 \%$ & $-7.3 \%$ \\
\hline SB4SULFA-03 & 3 & Sum & 96.9033 & 99.2659 & 100.0300 & -3.1267 & -0.7641 & $-3.1 \%$ & $-0.8 \%$ \\
\hline SB4SULFA-04 & 4 & $\mathrm{Al}_{2} \mathrm{O}_{3}$ & 9.3908 & 9.7344 & 8.9100 & 0.4808 & 0.8244 & $5.4 \%$ & $9.3 \%$ \\
\hline SB4SULFA-04 & 4 & $\mathrm{~B}_{2} \mathrm{O}_{3}$ & 5.0150 & 4.9960 & 4.9500 & 0.0650 & 0.0460 & $1.3 \%$ & $0.9 \%$ \\
\hline SB4SULFA-04 & 4 & $\mathrm{BaO}$ & 0.0416 & 0.0458 & 0.0500 & -0.0084 & -0.0042 & $-16.8 \%$ & $-8.4 \%$ \\
\hline SB4SULFA-04 & 4 & $\mathrm{CaO}$ & 0.9557 & 0.9438 & 0.9000 & 0.0557 & 0.0438 & $6.2 \%$ & $4.9 \%$ \\
\hline SB4SULFA-04 & 4 & $\mathrm{Ce}_{2} \mathrm{O}_{3}$ & 0.0401 & 0.0401 & 0.0600 & -0.0199 & -0.0199 & $-33.1 \%$ & $-33.1 \%$ \\
\hline SB4SULFA-04 & 4 & $\mathrm{Cr}_{2} \mathrm{O}_{3}$ & 0.0793 & 0.0871 & 0.0800 & -0.0007 & 0.0071 & $-0.9 \%$ & $8.8 \%$ \\
\hline SB4SULFA-04 & 4 & $\mathrm{CuO}$ & 0.0222 & 0.0218 & 0.0200 & 0.0022 & 0.0018 & $11.1 \%$ & $8.8 \%$ \\
\hline SB4SULFA-04 & 4 & $\mathrm{Fe}_{2} \mathrm{O}_{3}$ & 8.4888 & 8.7703 & 10.0200 & -1.5312 & -1.2497 & $-15.3 \%$ & $-12.5 \%$ \\
\hline SB4SULFA-04 & 4 & $\mathrm{~K}_{2} \mathrm{O}$ & 0.1436 & 0.1379 & 0.1200 & 0.0236 & 0.0179 & $19.7 \%$ & $14.9 \%$ \\
\hline SB4SULFA-04 & 4 & $\mathrm{La}_{2} \mathrm{O}_{3}$ & 0.0323 & 0.0323 & 0.0400 & -0.0077 & -0.0077 & $-19.4 \%$ & $-19.4 \%$ \\
\hline SB4SULFA-04 & 4 & $\mathrm{Li}_{2} \mathrm{O}$ & 4.8386 & 4.9728 & 4.9500 & -0.1114 & 0.0228 & $-2.2 \%$ & $0.5 \%$ \\
\hline SB4SULFA-04 & 4 & $\mathrm{MgO}$ & 0.9137 & 0.9695 & 0.9600 & -0.0463 & 0.0095 & $-4.8 \%$ & $1.0 \%$ \\
\hline SB4SULFA-04 & 4 & $\mathrm{MnO}$ & 2.1079 & 2.1989 & 2.0600 & 0.0479 & 0.1389 & $2.3 \%$ & $6.7 \%$ \\
\hline SB4SULFA-04 & 4 & $\mathrm{Na}_{2} \mathrm{O}$ & 14.4573 & 13.9602 & 13.9500 & 0.5073 & 0.0102 & $3.6 \%$ & $0.1 \%$ \\
\hline SB4SULFA-04 & 4 & $\mathrm{NiO}$ & 0.5659 & 0.6081 & 0.5900 & -0.0241 & 0.0181 & $-4.1 \%$ & $3.1 \%$ \\
\hline SB4SULFA-04 & 4 & $\mathrm{PbO}$ & 0.0272 & 0.0272 & 0.0400 & -0.0128 & -0.0128 & $-32.0 \%$ & $-32.0 \%$ \\
\hline SB4SULFA-04 & 4 & $\mathrm{SO}_{4}$ & 0.6524 & 0.6524 & 0.7500 & -0.0976 & -0.0976 & $-13.0 \%$ & $-13.0 \%$ \\
\hline SB4SULFA-04 & 4 & $\mathrm{SiO}_{2}$ & 46.6902 & 48.5707 & 48.4900 & -1.7998 & 0.0807 & $-3.7 \%$ & $0.2 \%$ \\
\hline SB4SULFA-04 & 4 & $\mathrm{ThO}_{2}$ & 0.1300 & 0.1300 & 0.0200 & 0.1100 & 0.1100 & $550.0 \%$ & $550.0 \%$ \\
\hline SB4SULFA-04 & 4 & $\mathrm{TiO}_{2}$ & 0.0083 & 0.0089 & 0.0100 & -0.0017 & -0.0011 & $-16.6 \%$ & $-10.7 \%$ \\
\hline SB4SULFA-04 & 4 & $\mathrm{U}_{3} \mathrm{O}_{8}$ & 2.6237 & 2.9197 & 2.9100 & -0.2863 & 0.0097 & $-9.8 \%$ & $0.3 \%$ \\
\hline SB4SULFA-04 & 4 & $\mathrm{ZnO}$ & 0.0364 & 0.0364 & 0.0400 & -0.0036 & -0.0036 & $-9.0 \%$ & $-9.0 \%$ \\
\hline SB4SULFA-04 & 4 & $\mathrm{ZrO}_{2}$ & 0.0797 & 0.0797 & 0.0900 & -0.0103 & -0.0103 & $-11.4 \%$ & $-11.4 \%$ \\
\hline SB4SULFA-04 & 4 & Sum & 97.3409 & 99.9440 & 100.0100 & -2.6691 & -0.0660 & $-2.7 \%$ & $-0.1 \%$ \\
\hline SB4SULFA-05 & 5 & $\mathrm{Al}_{2} \mathrm{O}_{3}$ & 9.3200 & 9.5396 & 8.9100 & 0.4100 & 0.6296 & $4.6 \%$ & $7.1 \%$ \\
\hline SB4SULFA-05 & 5 & $\mathrm{~B}_{2} \mathrm{O}_{3}$ & 5.1277 & 4.9968 & 4.9400 & 0.1877 & 0.0568 & $3.8 \%$ & $1.2 \%$ \\
\hline SB4SULFA-05 & 5 & $\mathrm{BaO}$ & 0.0486 & 0.0518 & 0.0500 & -0.0014 & 0.0018 & $-2.9 \%$ & $3.5 \%$ \\
\hline SB4SULFA-05 & 5 & $\mathrm{CaO}$ & 1.0137 & 0.9911 & 0.9000 & 0.1137 & 0.0911 & $12.6 \%$ & $10.1 \%$ \\
\hline SB4SULFA-05 & 5 & $\mathrm{Ce}_{2} \mathrm{O}_{3}$ & 0.0445 & 0.0445 & 0.0600 & -0.0155 & -0.0155 & $-25.8 \%$ & $-25.8 \%$ \\
\hline SB4SULFA-05 & 5 & $\mathrm{Cr}_{2} \mathrm{O}_{3}$ & 0.0782 & 0.0836 & 0.0800 & -0.0018 & 0.0036 & $-2.3 \%$ & $4.4 \%$ \\
\hline SB4SULFA-05 & 5 & $\mathrm{CuO}$ & 0.0250 & 0.0243 & 0.0200 & 0.0050 & 0.0043 & $25.2 \%$ & $21.5 \%$ \\
\hline SB4SULFA-05 & 5 & $\mathrm{Fe}_{2} \mathrm{O}_{3}$ & 8.8892 & 8.8256 & 10.0200 & -1.1308 & -1.1944 & $-11.3 \%$ & $-11.9 \%$ \\
\hline SB4SULFA-05 & 5 & $\mathrm{~K}_{2} \mathrm{O}$ & 0.1476 & 0.1387 & 0.1200 & 0.0276 & 0.0187 & $23.0 \%$ & $15.6 \%$ \\
\hline SB4SULFA-05 & 5 & $\mathrm{La}_{2} \mathrm{O}_{3}$ & 0.0367 & 0.0367 & 0.0400 & -0.0034 & -0.0034 & $-8.4 \%$ & $-8.4 \%$ \\
\hline SB4SULFA-05 & 5 & $\mathrm{Li}_{2} \mathrm{O}$ & 4.9248 & 5.0073 & 4.9400 & -0.0152 & 0.0673 & $-0.3 \%$ & $1.4 \%$ \\
\hline SB4SULFA-05 & 5 & $\mathrm{MgO}$ & 0.9117 & 0.9505 & 0.9600 & -0.0483 & -0.0095 & $-5.0 \%$ & $-1.0 \%$ \\
\hline SB4SULFA-05 & 5 & $\mathrm{MnO}$ & 1.9981 & 2.1543 & 2.0600 & -0.0619 & 0.0943 & $-3.0 \%$ & $4.6 \%$ \\
\hline SB4SULFA-05 & 5 & $\mathrm{Na}_{2} \mathrm{O}$ & 14.5247 & 13.7892 & 13.9400 & 0.5847 & -0.1508 & $4.2 \%$ & $-1.1 \%$ \\
\hline SB4SULFA-05 & 5 & $\mathrm{NiO}$ & 0.5341 & 0.5972 & 0.5900 & -0.0559 & 0.0072 & $-9.5 \%$ & $1.2 \%$ \\
\hline SB4SULFA-05 & 5 & $\mathrm{PbO}$ & 0.0299 & 0.0299 & 0.0400 & -0.0101 & -0.0101 & $-25.3 \%$ & $-25.3 \%$ \\
\hline SB4SULFA-05 & 5 & $\mathrm{SO}_{4}$ & 0.6621 & 0.6621 & 0.8000 & -0.1379 & -0.1379 & $-17.2 \%$ & $-17.2 \%$ \\
\hline SB4SULFA-05 & 5 & $\mathrm{SiO}_{2}$ & 48.1877 & 49.2197 & 48.4700 & -0.2823 & 0.7497 & $-0.6 \%$ & $1.5 \%$ \\
\hline SB4SULFA-05 & 5 & $\mathrm{ThO}_{2}$ & 0.1391 & 0.1391 & 0.0200 & 0.1191 & 0.1191 & $595.5 \%$ & $595.5 \%$ \\
\hline SB4SULFA-05 & 5 & $\mathrm{TiO}_{2}$ & 0.0083 & 0.0088 & 0.0100 & -0.0017 & -0.0012 & $-16.6 \%$ & $-11.8 \%$ \\
\hline SB4SULFA-05 & 5 & $\mathrm{U}_{3} \mathrm{O}_{8}$ & 2.7534 & 2.9779 & 2.9100 & -0.1566 & 0.0679 & $-5.4 \%$ & $2.3 \%$ \\
\hline SB4SULFA-05 & 5 & $\mathrm{ZnO}$ & 0.0367 & 0.0367 & 0.0400 & -0.0033 & -0.0033 & $-8.2 \%$ & $-8.2 \%$ \\
\hline SB4SULFA-05 & 5 & $\mathrm{ZrO}_{2}$ & 0.0746 & 0.0746 & 0.0900 & -0.0154 & -0.0154 & $-17.1 \%$ & $-17.1 \%$ \\
\hline SB4SULFA-05 & 5 & Sum & 99.5164 & 100.3799 & 100.0100 & -0.4936 & 0.3699 & $-0.5 \%$ & $0.4 \%$ \\
\hline SB4SULFA-06 & 6 & $\mathrm{Al}_{2} \mathrm{O}_{3}$ & 7.4588 & 7.7316 & 8.9300 & -1.4712 & -1.1984 & $-16.5 \%$ & $-13.4 \%$ \\
\hline SB4SULFA-06 & 6 & $\mathrm{~B}_{2} \mathrm{O}_{3}$ & 8.9674 & 8.7394 & 8.6700 & 0.2974 & 0.0694 & $3.4 \%$ & $0.8 \%$ \\
\hline SB4SULFA-06 & 6 & $\mathrm{BaO}$ & 0.0421 & 0.0464 & 0.0500 & -0.0079 & -0.0036 & $-15.7 \%$ & $-7.2 \%$ \\
\hline SB4SULFA-06 & 6 & $\mathrm{CaO}$ & 0.9889 & 0.9767 & 0.9000 & 0.0889 & 0.0767 & $9.9 \%$ & $8.5 \%$ \\
\hline SB4SULFA-06 & 6 & $\mathrm{Ce}_{2} \mathrm{O}_{3}$ & 0.0410 & 0.0410 & 0.0600 & -0.0190 & -0.0190 & $-31.7 \%$ & $-31.7 \%$ \\
\hline SB4SULFA-06 & 6 & $\mathrm{Cr}_{2} \mathrm{O}_{3}$ & 0.0702 & 0.0770 & 0.0800 & -0.0098 & -0.0030 & $-12.3 \%$ & $-3.7 \%$ \\
\hline
\end{tabular}


WSRC-STI-2006-00038

Revision 0

Appendix B

Table B4. Average Measured and Bias-Corrected Chemical Compositions Versus Targeted Compositions by Oxide by SB4 Sulfate Study Glass (continued)

(100 -Batch 1; 200 -U std; 300 - LRM)

\begin{tabular}{|c|c|c|c|c|c|c|c|c|c|}
\hline Glass ID & Glass \# & Oxide & $\begin{array}{c}\text { Measured } \\
\text { (wt\%) }\end{array}$ & $\begin{array}{c}\text { Measured } \\
\text { Bias-Corrected } \\
\text { (wt \%) }\end{array}$ & $\begin{array}{c}\text { Targeted } \\
\text { (wt \%) }\end{array}$ & $\begin{array}{c}\text { Diff of } \\
\text { Measured }\end{array}$ & $\begin{array}{c}\text { Diff of } \\
\text { Meas. bc }\end{array}$ & $\begin{array}{l}\text { \% Diff of } \\
\text { Measured }\end{array}$ & $\begin{array}{l}\text { \% Diff of } \\
\text { Meas. bc }\end{array}$ \\
\hline SB4SULFA-06 & 6 & $\mathrm{CuO}$ & 0.0241 & 0.0236 & 0.0200 & 0.0041 & 0.0036 & $20.5 \%$ & $18.0 \%$ \\
\hline SB4SULFA-06 & 6 & $\mathrm{Fe}_{2} \mathrm{O}_{3}$ & 9.4610 & 9.3931 & 10.0400 & -0.5790 & -0.6469 & $-5.8 \%$ & $-6.4 \%$ \\
\hline SB4SULFA-06 & 6 & $\mathrm{~K}_{2} \mathrm{O}$ & 0.1443 & 0.1385 & 0.1200 & 0.0243 & 0.0185 & $20.2 \%$ & $15.4 \%$ \\
\hline SB4SULFA-06 & 6 & $\mathrm{La}_{2} \mathrm{O}_{3}$ & 0.0337 & 0.0337 & 0.0400 & -0.0063 & -0.0063 & $-15.7 \%$ & $-15.7 \%$ \\
\hline SB4SULFA-06 & 6 & $\mathrm{Li}_{2} \mathrm{O}$ & 4.9732 & 5.0565 & 4.9500 & 0.0232 & 0.1065 & $0.5 \%$ & $2.2 \%$ \\
\hline SB4SULFA-06 & 6 & $\mathrm{MgO}$ & 0.9311 & 0.9880 & 0.9600 & -0.0289 & 0.0280 & $-3.0 \%$ & $2.9 \%$ \\
\hline SB4SULFA-06 & 6 & $\mathrm{MnO}$ & 2.1434 & 2.2355 & 2.0700 & 0.0734 & 0.1655 & $3.5 \%$ & $8.0 \%$ \\
\hline SB4SULFA-06 & 6 & $\mathrm{Na}_{2} \mathrm{O}$ & 12.1792 & 11.7596 & 11.4900 & 0.6892 & 0.2696 & $6.0 \%$ & $2.3 \%$ \\
\hline SB4SULFA-06 & 6 & $\mathrm{NiO}$ & 0.5930 & 0.6367 & 0.5900 & 0.0030 & 0.0467 & $0.5 \%$ & $7.9 \%$ \\
\hline SB4SULFA-06 & 6 & $\mathrm{PbO}$ & 0.0272 & 0.0272 & 0.0400 & -0.0128 & -0.0128 & $-32.0 \%$ & $-32.0 \%$ \\
\hline SB4SULFA-06 & 6 & $\mathrm{SO}_{4}$ & 0.5243 & 0.5243 & 0.6000 & -0.0757 & -0.0757 & $-12.6 \%$ & $-12.6 \%$ \\
\hline SB4SULFA-06 & 6 & $\mathrm{SiO}_{2}$ & 47.8668 & 48.8904 & 47.3300 & 0.5368 & 1.5604 & $1.1 \%$ & $3.3 \%$ \\
\hline SB4SULFA-06 & 6 & $\mathrm{ThO}_{2}$ & 0.1405 & 0.1405 & 0.0200 & 0.1205 & 0.1205 & $602.7 \%$ & $602.7 \%$ \\
\hline SB4SULFA-06 & 6 & $\mathrm{TiO}_{2}$ & 0.0083 & 0.0089 & 0.0100 & -0.0017 & -0.0011 & $-16.6 \%$ & $-10.7 \%$ \\
\hline SB4SULFA-06 & 6 & $\mathrm{U}_{3} \mathrm{O}_{8}$ & 2.8507 & 3.0833 & 2.9100 & -0.0593 & 0.1733 & $-2.0 \%$ & $6.0 \%$ \\
\hline SB4SULFA-06 & 6 & $\mathrm{ZnO}$ & 0.0367 & 0.0367 & 0.0400 & -0.0033 & -0.0033 & $-8.2 \%$ & $-8.2 \%$ \\
\hline SB4SULFA-06 & 6 & $\mathrm{ZrO}_{2}$ & 0.0827 & 0.0827 & 0.0900 & -0.0073 & -0.0073 & $-8.1 \%$ & $-8.1 \%$ \\
\hline SB4SULFA-06 & 6 & Sum & 99.5888 & 100.6715 & 100.0100 & -0.4212 & 0.6615 & $-0.4 \%$ & $0.7 \%$ \\
\hline SB4SULFA-07 & 7 & $\mathrm{Al}_{2} \mathrm{O}_{3}$ & 9.2680 & 9.6069 & 8.9200 & 0.3480 & 0.6869 & $3.9 \%$ & $7.7 \%$ \\
\hline SB4SULFA-07 & 7 & $\mathrm{~B}_{2} \mathrm{O}_{3}$ & 8.4764 & 8.4392 & 8.6700 & -0.1936 & -0.2308 & $-2.2 \%$ & $-2.7 \%$ \\
\hline SB4SULFA-07 & 7 & $\mathrm{BaO}$ & 0.0391 & 0.0430 & 0.0500 & -0.0109 & -0.0070 & $-21.8 \%$ & $-14.0 \%$ \\
\hline SB4SULFA-07 & 7 & $\mathrm{CaO}$ & 0.9483 & 0.9366 & 0.9000 & 0.0483 & 0.0366 & $5.4 \%$ & $4.1 \%$ \\
\hline SB4SULFA-07 & 7 & $\mathrm{Ce}_{2} \mathrm{O}_{3}$ & 0.0366 & 0.0366 & 0.0600 & -0.0234 & -0.0234 & $-39.0 \%$ & $-39.0 \%$ \\
\hline SB4SULFA-07 & 7 & $\mathrm{Cr}_{2} \mathrm{O}_{3}$ & 0.0756 & 0.0831 & 0.0800 & -0.0044 & 0.0031 & $-5.5 \%$ & $3.8 \%$ \\
\hline SB4SULFA-07 & 7 & $\mathrm{CuO}$ & 0.0269 & 0.0264 & 0.0200 & 0.0069 & 0.0064 & $34.6 \%$ & $31.8 \%$ \\
\hline SB4SULFA-07 & 7 & $\mathrm{Fe}_{2} \mathrm{O}_{3}$ & 8.5174 & 8.7983 & 10.0300 & -1.5126 & -1.2317 & $-15.1 \%$ & $-12.3 \%$ \\
\hline SB4SULFA-07 & 7 & $\mathrm{~K}_{2} \mathrm{O}$ & 0.1443 & 0.1385 & 0.1200 & 0.0243 & 0.0185 & $20.2 \%$ & $15.4 \%$ \\
\hline SB4SULFA-07 & 7 & $\mathrm{La}_{2} \mathrm{O}_{3}$ & 0.0349 & 0.0349 & 0.0400 & -0.0051 & -0.0051 & $-12.8 \%$ & $-12.8 \%$ \\
\hline SB4SULFA-07 & 7 & $\mathrm{Li}_{2} \mathrm{O}$ & 4.8063 & 4.9396 & 4.9500 & -0.1437 & -0.0104 & $-2.9 \%$ & $-0.2 \%$ \\
\hline SB4SULFA-07 & 7 & $\mathrm{MgO}$ & 0.8909 & 0.9453 & 0.9600 & -0.0691 & -0.0147 & $-7.2 \%$ & $-1.5 \%$ \\
\hline SB4SULFA-07 & 7 & $\mathrm{MnO}$ & 2.0562 & 2.1447 & 2.0700 & -0.0138 & 0.0747 & $-0.7 \%$ & $3.6 \%$ \\
\hline SB4SULFA-07 & 7 & $\mathrm{Na}_{2} \mathrm{O}$ & 12.0646 & 11.6490 & 11.4900 & 0.5746 & 0.1590 & $5.0 \%$ & $1.4 \%$ \\
\hline SB4SULFA-07 & 7 & $\mathrm{NiO}$ & 0.5621 & 0.6037 & 0.5900 & -0.0279 & 0.0137 & $-4.7 \%$ & $2.3 \%$ \\
\hline SB4SULFA-07 & 7 & $\mathrm{PbO}$ & 0.0285 & 0.0285 & 0.0400 & -0.0115 & -0.0115 & $-28.6 \%$ & $-28.6 \%$ \\
\hline SB4SULFA-07 & 7 & $\mathrm{SO}_{4}$ & 0.5453 & 0.5453 & 0.6500 & -0.1047 & -0.1047 & $-16.1 \%$ & $-16.1 \%$ \\
\hline SB4SULFA-07 & 7 & $\mathrm{SiO}_{2}$ & 45.0323 & 46.8441 & 47.3000 & -2.2677 & -0.4559 & $-4.8 \%$ & $-1.0 \%$ \\
\hline SB4SULFA-07 & 7 & $\mathrm{ThO}_{2}$ & 0.1368 & 0.1368 & 0.0200 & 0.1168 & 0.1168 & $584.2 \%$ & $584.2 \%$ \\
\hline SB4SULFA-07 & 7 & $\mathrm{TiO}_{2}$ & 0.0083 & 0.0089 & 0.0100 & -0.0017 & -0.0011 & $-16.6 \%$ & $-10.7 \%$ \\
\hline SB4SULFA-07 & 7 & $\mathrm{U}_{3} \mathrm{O}_{8}$ & 2.6473 & 2.9466 & 2.9100 & -0.2627 & 0.0366 & $-9.0 \%$ & $1.3 \%$ \\
\hline SB4SULFA-07 & 7 & $\mathrm{ZnO}$ & 0.0342 & 0.0342 & 0.0400 & -0.0058 & -0.0058 & $-14.4 \%$ & $-14.4 \%$ \\
\hline SB4SULFA-07 & 7 & $\mathrm{ZrO}_{2}$ & 0.0831 & 0.0831 & 0.0900 & -0.0069 & -0.0069 & $-7.7 \%$ & $-7.7 \%$ \\
\hline SB4SULFA-07 & 7 & Sum & 96.4636 & 99.0532 & 100.0100 & -3.5464 & -0.9568 & $-3.5 \%$ & $-1.0 \%$ \\
\hline SB4SULFA-08 & 8 & $\mathrm{Al}_{2} \mathrm{O}_{3}$ & 9.4239 & 9.7686 & 8.9200 & 0.5039 & 0.8486 & $5.6 \%$ & $9.5 \%$ \\
\hline SB4SULFA-08 & 8 & $\mathrm{~B}_{2} \mathrm{O}_{3}$ & 8.4361 & 8.4021 & 8.6600 & -0.2239 & -0.2579 & $-2.6 \%$ & $-3.0 \%$ \\
\hline SB4SULFA-08 & 8 & $\mathrm{BaO}$ & 0.0391 & 0.0430 & 0.0500 & -0.0109 & -0.0070 & $-21.8 \%$ & $-14.0 \%$ \\
\hline SB4SULFA-08 & 8 & $\mathrm{CaO}$ & 0.9707 & 0.9587 & 0.9000 & 0.0707 & 0.0587 & $7.9 \%$ & $6.5 \%$ \\
\hline SB4SULFA-08 & 8 & $\mathrm{Ce}_{2} \mathrm{O}_{3}$ & 0.0384 & 0.0384 & 0.0600 & -0.0216 & -0.0216 & $-36.1 \%$ & $-36.1 \%$ \\
\hline SB4SULFA-08 & 8 & $\mathrm{Cr}_{2} \mathrm{O}_{3}$ & 0.0723 & 0.0794 & 0.0800 & -0.0077 & -0.0006 & $-9.6 \%$ & $-0.7 \%$ \\
\hline SB4SULFA-08 & 8 & $\mathrm{CuO}$ & 0.0257 & 0.0251 & 0.0200 & 0.0057 & 0.0051 & $28.3 \%$ & $25.6 \%$ \\
\hline SB4SULFA-08 & 8 & $\mathrm{Fe}_{2} \mathrm{O}_{3}$ & 8.5711 & 8.8549 & 10.0300 & -1.4589 & -1.1751 & $-14.5 \%$ & $-11.7 \%$ \\
\hline SB4SULFA-08 & 8 & $\mathrm{~K}_{2} \mathrm{O}$ & 0.1455 & 0.1397 & 0.1200 & 0.0255 & 0.0197 & $21.2 \%$ & $16.4 \%$ \\
\hline SB4SULFA-08 & 8 & $\mathrm{La}_{2} \mathrm{O}_{3}$ & 0.0346 & 0.0346 & 0.0400 & -0.0054 & -0.0054 & $-13.5 \%$ & $-13.5 \%$ \\
\hline SB4SULFA-08 & 8 & $\mathrm{Li}_{2} \mathrm{O}$ & 4.8440 & 4.9783 & 4.9500 & -0.1060 & 0.0283 & $-2.1 \%$ & $0.6 \%$ \\
\hline SB4SULFA-08 & 8 & $\mathrm{MgO}$ & 0.8855 & 0.9397 & 0.9600 & -0.0745 & -0.0203 & $-7.8 \%$ & $-2.1 \%$ \\
\hline SB4SULFA-08 & 8 & $\mathrm{MnO}$ & 2.0853 & 2.1746 & 2.0700 & 0.0153 & 0.1046 & $0.7 \%$ & $5.1 \%$ \\
\hline SB4SULFA-08 & 8 & $\mathrm{Na}_{2} \mathrm{O}$ & 12.1387 & 11.7204 & 11.4800 & 0.6587 & 0.2404 & $5.7 \%$ & $2.1 \%$ \\
\hline SB4SULFA-08 & 8 & $\mathrm{NiO}$ & 0.5599 & 0.6012 & 0.5900 & -0.0301 & 0.0112 & $-5.1 \%$ & $1.9 \%$ \\
\hline SB4SULFA-08 & 8 & $\mathrm{PbO}$ & 0.0261 & 0.0261 & 0.0400 & -0.0139 & -0.0139 & $-34.7 \%$ & $-34.7 \%$ \\
\hline SB4SULFA-08 & 8 & $\mathrm{SO}_{4}$ & 0.5505 & 0.5505 & 0.7000 & -0.1495 & -0.1495 & $-21.4 \%$ & $-21.4 \%$ \\
\hline SB4SULFA-08 & 8 & $\mathrm{SiO}_{2}$ & 44.8718 & 46.6760 & 47.2800 & -2.4082 & -0.6040 & $-5.1 \%$ & $-1.3 \%$ \\
\hline SB4SULFA-08 & 8 & $\mathrm{ThO}_{2}$ & 0.1331 & 0.1331 & 0.0200 & 0.1131 & 0.1131 & $565.7 \%$ & $565.7 \%$ \\
\hline SB4SULFA-08 & 8 & $\mathrm{TiO}_{2}$ & 0.0083 & 0.0089 & 0.0100 & -0.0017 & -0.0011 & $-16.6 \%$ & $-10.7 \%$ \\
\hline
\end{tabular}


WSRC-STI-2006-00038

Revision 0

Appendix B

Table B4. Average Measured and Bias-Corrected Chemical Compositions Versus Targeted Compositions by Oxide by SB4 Sulfate Study Glass (continued)

(100 -Batch 1; 200 -U std; 300 - LRM)

\begin{tabular}{|c|c|c|c|c|c|c|c|c|c|}
\hline Glass ID & Glass \# & Oxide & $\begin{array}{l}\text { Measured } \\
\text { (wt\%) }\end{array}$ & $\begin{array}{c}\text { Measured } \\
\text { Bias-Corrected } \\
\text { (wt \%) }\end{array}$ & $\begin{array}{c}\text { Targeted } \\
\text { (wt } \%)\end{array}$ & $\begin{array}{c}\text { Diff of } \\
\text { Measured }\end{array}$ & $\begin{array}{c}\text { Diff of } \\
\text { Meas. bc }\end{array}$ & $\begin{array}{l}\text { \% Diff of } \\
\text { Measured }\end{array}$ & $\begin{array}{l}\text { \% Diff of } \\
\text { Meas. bc }\end{array}$ \\
\hline SB4SULFA-08 & 8 & $\mathrm{U}_{3} \mathrm{O}_{8}$ & 2.6827 & 2.9859 & 2.9100 & -0.2273 & 0.0759 & $-7.8 \%$ & $2.6 \%$ \\
\hline SB4SULFA-08 & 8 & $\mathrm{ZnO}$ & 0.0613 & 0.0613 & 0.0400 & 0.0213 & 0.0213 & $53.3 \%$ & $53.3 \%$ \\
\hline SB4SULFA-08 & 8 & $\mathrm{ZrO}_{2}$ & 0.0780 & 0.0780 & 0.0900 & -0.0120 & -0.0120 & $-13.3 \%$ & $-13.3 \%$ \\
\hline SB4SULFA-08 & 8 & Sum & 96.6827 & 99.2785 & 100.0200 & -3.3373 & -0.7415 & $-3.3 \%$ & $-0.7 \%$ \\
\hline SB4SULFA-09 & 9 & $\mathrm{Al}_{2} \mathrm{O}_{3}$ & 9.2444 & 9.5825 & 8.9100 & 0.3344 & 0.6725 & $3.8 \%$ & $7.5 \%$ \\
\hline SB4SULFA-09 & 9 & $\mathrm{~B}_{2} \mathrm{O}_{3}$ & 8.6052 & 8.5670 & 8.6600 & -0.0548 & -0.0930 & $-0.6 \%$ & $-1.1 \%$ \\
\hline SB4SULFA-09 & 9 & $\mathrm{BaO}$ & 0.0396 & 0.0436 & 0.0500 & -0.0104 & -0.0064 & $-20.7 \%$ & $-12.7 \%$ \\
\hline SB4SULFA-09 & 9 & $\mathrm{CaO}$ & 1.0274 & 1.0147 & 0.9000 & 0.1274 & 0.1147 & $14.2 \%$ & $12.7 \%$ \\
\hline SB4SULFA-09 & 9 & $\mathrm{Ce}_{2} \mathrm{O}_{3}$ & 0.0398 & 0.0398 & 0.0600 & -0.0202 & -0.0202 & $-33.6 \%$ & $-33.6 \%$ \\
\hline SB4SULFA-09 & 9 & $\mathrm{Cr}_{2} \mathrm{O}_{3}$ & 0.0698 & 0.0766 & 0.0800 & -0.0102 & -0.0034 & $-12.8 \%$ & $-4.2 \%$ \\
\hline SB4SULFA-09 & 9 & $\mathrm{CuO}$ & 0.0263 & 0.0257 & 0.0200 & 0.0063 & 0.0057 & $31.4 \%$ & $28.7 \%$ \\
\hline SB4SULFA-09 & 9 & $\mathrm{Fe}_{2} \mathrm{O}_{3}$ & 8.5067 & 8.7871 & 10.0200 & -1.5133 & -1.2329 & $-15.1 \%$ & $-12.3 \%$ \\
\hline SB4SULFA-09 & 9 & $\mathrm{~K}_{2} \mathrm{O}$ & 0.1500 & 0.1440 & 0.1200 & 0.0300 & 0.0240 & $25.0 \%$ & $20.0 \%$ \\
\hline SB4SULFA-09 & 9 & $\mathrm{La}_{2} \mathrm{O}_{3}$ & 0.0346 & 0.0346 & 0.0400 & -0.0054 & -0.0054 & $-13.5 \%$ & $-13.5 \%$ \\
\hline SB4SULFA-09 & 9 & $\mathrm{Li}_{2} \mathrm{O}$ & 4.7794 & 4.9119 & 4.9500 & -0.1706 & -0.0381 & $-3.4 \%$ & $-0.8 \%$ \\
\hline SB4SULFA-09 & 9 & $\mathrm{MgO}$ & 0.8839 & 0.9379 & 0.9600 & -0.0761 & -0.0221 & $-7.9 \%$ & $-2.3 \%$ \\
\hline SB4SULFA-09 & 9 & $\mathrm{MnO}$ & 2.1014 & 2.1918 & 2.0600 & 0.0414 & 0.1318 & $2.0 \%$ & $6.4 \%$ \\
\hline SB4SULFA-09 & 9 & $\mathrm{Na}_{2} \mathrm{O}$ & 12.0242 & 11.6099 & 11.4800 & 0.5442 & 0.1299 & $4.7 \%$ & $1.1 \%$ \\
\hline SB4SULFA-09 & 9 & $\mathrm{NiO}$ & 0.5631 & 0.6047 & 0.5900 & -0.0269 & 0.0147 & $-4.6 \%$ & $2.5 \%$ \\
\hline SB4SULFA-09 & 9 & $\mathrm{PbO}$ & 0.0285 & 0.0285 & 0.0400 & -0.0115 & -0.0115 & $-28.6 \%$ & $-28.6 \%$ \\
\hline SB4SULFA-09 & 9 & $\mathrm{SO}_{4}$ & 0.6157 & 0.6157 & 0.7500 & -0.1343 & -0.1343 & $-17.9 \%$ & $-17.9 \%$ \\
\hline SB4SULFA-09 & 9 & $\mathrm{SiO}_{2}$ & 45.2462 & 47.0668 & 47.2500 & -2.0038 & -0.1832 & $-4.2 \%$ & $-0.4 \%$ \\
\hline SB4SULFA-09 & 9 & $\mathrm{ThO}_{2}$ & 0.1343 & 0.1343 & 0.0200 & 0.1143 & 0.1143 & $571.4 \%$ & $571.4 \%$ \\
\hline SB4SULFA-09 & 9 & $\mathrm{TiO}_{2}$ & 0.0083 & 0.0089 & 0.0100 & -0.0017 & -0.0011 & $-16.6 \%$ & $-10.7 \%$ \\
\hline SB4SULFA-09 & 9 & $\mathrm{U}_{3} \mathrm{O}_{8}$ & 2.6473 & 2.9461 & 2.9100 & -0.2627 & 0.0361 & $-9.0 \%$ & $1.2 \%$ \\
\hline SB4SULFA-09 & 9 & $\mathrm{ZnO}$ & 0.0389 & 0.0389 & 0.0400 & -0.0011 & -0.0011 & $-2.8 \%$ & $-2.8 \%$ \\
\hline SB4SULFA-09 & 9 & $\mathrm{ZrO}_{2}$ & 0.0841 & 0.0841 & 0.0900 & -0.0059 & -0.0059 & $-6.6 \%$ & $-6.6 \%$ \\
\hline SB4SULFA-09 & 9 & Sum & 96.8990 & 99.4951 & 100.0100 & -3.1110 & -0.5149 & $-3.1 \%$ & $-0.5 \%$ \\
\hline SB4SULFA-10 & 10 & $\mathrm{Al}_{2} \mathrm{O}_{3}$ & 9.2963 & 9.6365 & 8.9100 & 0.3863 & 0.7265 & $4.3 \%$ & $8.2 \%$ \\
\hline SB4SULFA-10 & 10 & $\mathrm{~B}_{2} \mathrm{O}_{3}$ & 8.6213 & 8.5863 & 8.6500 & -0.0287 & -0.0637 & $-0.3 \%$ & $-0.7 \%$ \\
\hline SB4SULFA-10 & 10 & $\mathrm{BaO}$ & 0.0410 & 0.0452 & 0.0500 & -0.0090 & -0.0048 & $-17.9 \%$ & $-9.7 \%$ \\
\hline SB4SULFA-10 & 10 & $\mathrm{CaO}$ & 0.9354 & 0.9238 & 0.9000 & 0.0354 & 0.0238 & $3.9 \%$ & $2.6 \%$ \\
\hline SB4SULFA-10 & 10 & $\mathrm{Ce}_{2} \mathrm{O}_{3}$ & 0.0366 & 0.0366 & 0.0600 & -0.0234 & -0.0234 & $-39.0 \%$ & $-39.0 \%$ \\
\hline SB4SULFA-10 & 10 & $\mathrm{Cr}_{2} \mathrm{O}_{3}$ & 0.0775 & 0.0851 & 0.0800 & -0.0025 & 0.0051 & $-3.2 \%$ & $6.3 \%$ \\
\hline SB4SULFA-10 & 10 & $\mathrm{CuO}$ & 0.0228 & 0.0224 & 0.0200 & 0.0028 & 0.0024 & $14.2 \%$ & $11.9 \%$ \\
\hline SB4SULFA-10 & 10 & $\mathrm{Fe}_{2} \mathrm{O}_{3}$ & 8.6819 & 8.9681 & 10.0200 & -1.3381 & -1.0519 & $-13.4 \%$ & $-10.5 \%$ \\
\hline SB4SULFA-10 & 10 & $\mathrm{~K}_{2} \mathrm{O}$ & 0.1337 & 0.1284 & 0.1200 & 0.0137 & 0.0084 & $11.4 \%$ & $7.0 \%$ \\
\hline SB4SULFA-10 & 10 & $\mathrm{La}_{2} \mathrm{O}_{3}$ & 0.0340 & 0.0340 & 0.0400 & -0.0060 & -0.0060 & $-15.0 \%$ & $-15.0 \%$ \\
\hline SB4SULFA-10 & 10 & $\mathrm{Li}_{2} \mathrm{O}$ & 4.8225 & 4.9562 & 4.9400 & -0.1175 & 0.0162 & $-2.4 \%$ & $0.3 \%$ \\
\hline SB4SULFA-10 & 10 & $\mathrm{MgO}$ & 0.9137 & 0.9695 & 0.9600 & -0.0463 & 0.0095 & $-4.8 \%$ & $1.0 \%$ \\
\hline SB4SULFA-10 & 10 & $\mathrm{MnO}$ & 2.0853 & 2.1749 & 2.0600 & 0.0253 & 0.1149 & $1.2 \%$ & $5.6 \%$ \\
\hline SB4SULFA-10 & 10 & $\mathrm{Na}_{2} \mathrm{O}$ & 11.9736 & 11.5616 & 11.4700 & 0.5036 & 0.0916 & $4.4 \%$ & $0.8 \%$ \\
\hline SB4SULFA-10 & 10 & $\mathrm{NiO}$ & 0.5526 & 0.5935 & 0.5900 & -0.0374 & 0.0035 & $-6.3 \%$ & $0.6 \%$ \\
\hline SB4SULFA-10 & 10 & $\mathrm{PbO}$ & 0.0256 & 0.0256 & 0.0400 & -0.0144 & -0.0144 & $-36.0 \%$ & $-36.0 \%$ \\
\hline SB4SULFA-10 & 10 & $\mathrm{SO}_{4}$ & 0.6097 & 0.6097 & 0.8000 & -0.1903 & -0.1903 & $-23.8 \%$ & $-23.8 \%$ \\
\hline SB4SULFA-10 & 10 & $\mathrm{SiO}_{2}$ & 45.4601 & 47.2894 & 47.2300 & -1.7699 & 0.0594 & $-3.7 \%$ & $0.1 \%$ \\
\hline SB4SULFA-10 & 10 & $\mathrm{ThO}_{2}$ & 0.1371 & 0.1371 & 0.0200 & 0.1171 & 0.1171 & $585.6 \%$ & $585.6 \%$ \\
\hline SB4SULFA-10 & 10 & $\mathrm{TiO}_{2}$ & 0.0113 & 0.0121 & 0.0100 & 0.0013 & 0.0021 & $12.6 \%$ & $20.6 \%$ \\
\hline SB4SULFA-10 & 10 & $\mathrm{U}_{3} \mathrm{O}_{8}$ & 2.7063 & 3.0120 & 2.9100 & -0.2037 & 0.1020 & $-7.0 \%$ & $3.5 \%$ \\
\hline SB4SULFA-10 & 10 & $\mathrm{ZnO}$ & 0.0349 & 0.0349 & 0.0400 & -0.0051 & -0.0051 & $-12.9 \%$ & $-12.9 \%$ \\
\hline SB4SULFA-10 & 10 & $\mathrm{ZrO}_{2}$ & 0.0719 & 0.0719 & 0.0900 & -0.0181 & -0.0181 & $-20.1 \%$ & $-20.1 \%$ \\
\hline SB4SULFA-10 & 10 & Sum & 97.2850 & 99.9146 & 100.0100 & -2.7250 & -0.0954 & $-2.7 \%$ & $-0.1 \%$ \\
\hline Batch 1 & 100 & $\mathrm{Al}_{2} \mathrm{O}_{3}$ & 4.7348 & 4.8770 & 4.8770 & -0.1422 & 0.0000 & $-2.9 \%$ & $0.0 \%$ \\
\hline Batch 1 & 100 & $\mathrm{~B}_{2} \mathrm{O}_{3}$ & 7.8968 & 7.7770 & 7.7770 & 0.1198 & 0.0000 & $1.5 \%$ & $0.0 \%$ \\
\hline Batch 1 & 100 & $\mathrm{BaO}$ & 0.1394 & 0.1510 & 0.1510 & -0.0116 & 0.0000 & $-7.7 \%$ & $0.0 \%$ \\
\hline Batch 1 & 100 & $\mathrm{CaO}$ & 1.2416 & 1.2200 & 1.2200 & 0.0216 & 0.0000 & $1.8 \%$ & $0.0 \%$ \\
\hline Batch 1 & 100 & $\mathrm{Ce}_{2} \mathrm{O}_{3}$ & 0.0059 & 0.0059 & 0.0000 & 0.0059 & 0.0059 & & \\
\hline Batch 1 & 100 & $\mathrm{Cr}_{2} \mathrm{O}_{3}$ & 0.0988 & 0.1070 & 0.1070 & -0.0082 & 0.0000 & $-7.7 \%$ & $0.0 \%$ \\
\hline Batch 1 & 100 & $\mathrm{CuO}$ & 0.4092 & 0.3990 & 0.3990 & 0.0102 & 0.0000 & $2.6 \%$ & $0.0 \%$ \\
\hline Batch 1 & 100 & $\mathrm{Fe}_{2} \mathrm{O}_{3}$ & 12.6791 & 12.8390 & 12.8390 & -0.1599 & 0.0000 & $-1.2 \%$ & $0.0 \%$ \\
\hline Batch 1 & 100 & $\mathrm{~K}_{2} \mathrm{O}$ & 3.5024 & 3.3270 & 3.3270 & 0.1754 & 0.0000 & $5.3 \%$ & $0.0 \%$ \\
\hline Batch 1 & 100 & $\mathrm{La}_{2} \mathrm{O}_{3}$ & 0.0059 & 0.0059 & 0.0000 & 0.0059 & 0.0059 & & \\
\hline
\end{tabular}


WSRC-STI-2006-00038

Revision 0

Appendix B

Table B4. Average Measured and Bias-Corrected Chemical Compositions Versus Targeted Compositions by Oxide by SB4 Sulfate Study Glass (continued) (100 -Batch 1; 200 -U std; 300 - LRM)

\begin{tabular}{|c|c|c|c|c|c|c|c|c|c|}
\hline Glass ID & Glass \# & Oxide & $\begin{array}{c}\text { Measured } \\
\text { (wt\%) }\end{array}$ & $\begin{array}{c}\text { Measured } \\
\text { Bias-Corrected } \\
(w t \%)\end{array}$ & $\begin{array}{c}\text { Targeted } \\
\text { (wt\%) }\end{array}$ & $\begin{array}{c}\text { Diff of } \\
\text { Measured }\end{array}$ & $\begin{array}{c}\text { Diff of } \\
\text { Meas. bc }\end{array}$ & $\begin{array}{l}\text { \% Diff of } \\
\text { Measured }\end{array}$ & $\begin{array}{l}\text { \% Diff of } \\
\text { Meas. bc }\end{array}$ \\
\hline Batch 1 & 100 & $\mathrm{Li}_{2} \mathrm{O}$ & 4.3327 & 4.4290 & 4.4290 & -0.0963 & 0.0000 & $-2.2 \%$ & $0.0 \%$ \\
\hline Batch 1 & 100 & $\mathrm{MgO}$ & 1.3493 & 1.4190 & 1.4190 & -0.0697 & 0.0000 & $-4.9 \%$ & $0.0 \%$ \\
\hline Batch 1 & 100 & $\mathrm{MnO}$ & 1.6280 & 1.7260 & 1.7260 & -0.0980 & 0.0000 & $-5.7 \%$ & $0.0 \%$ \\
\hline Batch 1 & 100 & $\mathrm{Na}_{2} \mathrm{O}$ & 9.4034 & 9.0030 & 9.0030 & 0.4004 & 0.0000 & $4.4 \%$ & $0.0 \%$ \\
\hline Batch 1 & 100 & $\mathrm{NiO}$ & 0.6855 & 0.7510 & 0.7510 & -0.0655 & 0.0000 & $-8.7 \%$ & $0.0 \%$ \\
\hline Batch 1 & 100 & $\mathrm{PbO}$ & 0.0108 & 0.0108 & 0.0000 & 0.0108 & 0.0108 & & \\
\hline Batch 1 & 100 & $\mathrm{SO}_{4}$ & 0.0749 & 0.0749 & 0.0000 & 0.0749 & 0.0749 & & \\
\hline Batch 1 & 100 & $\mathrm{SiO}_{2}$ & 48.7226 & 50.2200 & 50.2200 & -1.4974 & 0.0000 & $-3.0 \%$ & $0.0 \%$ \\
\hline Batch 1 & 100 & $\mathrm{ThO}_{2}$ & 0.0569 & 0.0569 & 0.0000 & 0.0569 & 0.0569 & & \\
\hline Batch 1 & 100 & $\mathrm{TiO}_{2}$ & 0.6361 & 0.6770 & 0.6770 & -0.0409 & 0.0000 & $-6.0 \%$ & $0.0 \%$ \\
\hline Batch 1 & 100 & $\mathrm{U}_{3} \mathrm{O}_{8}$ & 0.0590 & 0.0647 & 0.0000 & 0.0590 & 0.0647 & & \\
\hline Batch 1 & 100 & $\mathrm{ZnO}$ & 0.0062 & 0.0062 & 0.0000 & 0.0062 & 0.0062 & & \\
\hline Batch 1 & 100 & $\mathrm{ZrO}_{2}$ & 0.0817 & 0.0817 & 0.0980 & -0.0163 & -0.0163 & $-16.6 \%$ & $-16.6 \%$ \\
\hline Batch 1 & 100 & Sum & 97.7606 & 99.2290 & 99.0200 & -1.2594 & 0.2090 & $-1.3 \%$ & $0.2 \%$ \\
\hline U std & 200 & $\mathrm{Al}_{2} \mathrm{O}_{3}$ & 3.9868 & 4.1067 & 4.1000 & -0.1132 & 0.0067 & $-2.8 \%$ & $0.2 \%$ \\
\hline U std & 200 & $\mathrm{~B}_{2} \mathrm{O}_{3}$ & 9.1499 & 9.0158 & 9.2090 & -0.0591 & -0.1932 & $-0.6 \%$ & $-2.1 \%$ \\
\hline U std & 200 & $\mathrm{BaO}$ & 0.0056 & 0.0061 & 0.0000 & 0.0056 & 0.0061 & & \\
\hline U std & 200 & $\mathrm{CaO}$ & 1.3306 & 1.3076 & 1.3010 & 0.0296 & 0.0066 & $2.3 \%$ & $0.5 \%$ \\
\hline U std & 200 & $\mathrm{Ce}_{2} \mathrm{O}_{3}$ & 0.0059 & 0.0059 & 0.0000 & 0.0059 & 0.0059 & & \\
\hline U std & 200 & $\mathrm{Cr}_{2} \mathrm{O}_{3}$ & 0.2312 & 0.2504 & 0.0000 & 0.2312 & 0.2504 & & \\
\hline U std & 200 & $\mathrm{CuO}$ & 0.0063 & 0.0061 & 0.0000 & 0.0063 & 0.0061 & & \\
\hline U std & 200 & $\mathrm{Fe}_{2} \mathrm{O}_{3}$ & 12.1548 & 12.3062 & 13.1960 & -1.0412 & -0.8898 & $-7.9 \%$ & $-6.7 \%$ \\
\hline U std & 200 & $\mathrm{~K}_{2} \mathrm{O}$ & 3.1962 & 3.0363 & 2.9990 & 0.1972 & 0.0373 & $6.6 \%$ & $1.2 \%$ \\
\hline U std & 200 & $\mathrm{La}_{2} \mathrm{O}_{3}$ & 0.0059 & 0.0059 & 0.0000 & 0.0059 & 0.0059 & & \\
\hline U std & 200 & $\mathrm{Li}_{2} \mathrm{O}$ & 3.1020 & 3.1709 & 3.0570 & 0.0450 & 0.1139 & $1.5 \%$ & $3.7 \%$ \\
\hline U std & 200 & $\mathrm{MgO}$ & 1.1158 & 1.1730 & 1.2100 & -0.0942 & -0.0370 & $-7.8 \%$ & $-3.1 \%$ \\
\hline U std & 200 & $\mathrm{MnO}$ & 2.7018 & 2.8649 & 2.8920 & -0.1902 & -0.0271 & $-6.6 \%$ & $-0.9 \%$ \\
\hline U std & 200 & $\mathrm{Na}_{2} \mathrm{O}$ & 11.9804 & 11.4709 & 11.7950 & 0.1854 & -0.3241 & $1.6 \%$ & $-2.7 \%$ \\
\hline U std & 200 & $\mathrm{NiO}$ & 0.9896 & 1.0844 & 1.1200 & -0.1304 & -0.0356 & $-11.6 \%$ & $-3.2 \%$ \\
\hline U std & 200 & $\mathrm{PbO}$ & 0.0108 & 0.0108 & 0.0000 & 0.0108 & 0.0108 & & \\
\hline U std & 200 & $\mathrm{SO}_{4}$ & 0.0749 & 0.0749 & 0.0000 & 0.0749 & 0.0749 & & \\
\hline U std & 200 & $\mathrm{SiO}_{2}$ & 42.8038 & 44.1175 & 45.3530 & -2.5492 & -1.2355 & $-5.6 \%$ & $-2.7 \%$ \\
\hline U std & 200 & $\mathrm{ThO}_{2}$ & 0.0569 & 0.0569 & 0.0000 & 0.0569 & 0.0569 & & \\
\hline U std & 200 & $\mathrm{TiO}_{2}$ & 0.8924 & 0.9496 & 1.0490 & -0.1566 & -0.0994 & $-14.9 \%$ & $-9.5 \%$ \\
\hline U std & 200 & $\mathrm{U}_{3} \mathrm{O}_{8}$ & 2.1933 & 2.4060 & 2.4060 & -0.2127 & 0.0000 & $-8.8 \%$ & $0.0 \%$ \\
\hline U std & 200 & $\mathrm{ZnO}$ & 0.0062 & 0.0062 & 0.0000 & 0.0062 & 0.0062 & & \\
\hline U std & 200 & $\mathrm{ZrO}_{2}$ & 0.0065 & 0.0065 & 0.0000 & 0.0065 & 0.0065 & & \\
\hline U std & 200 & Sum & 96.0075 & 97.4397 & 99.6870 & -3.6795 & -2.2473 & $-3.7 \%$ & $-2.3 \%$ \\
\hline LRM & 300 & $\mathrm{Al}_{2} \mathrm{O}_{3}$ & 9.9325 & 10.2106 & 10.0000 & -0.0675 & 0.2106 & $-0.7 \%$ & $2.1 \%$ \\
\hline LRM & 300 & $\mathrm{~B}_{2} \mathrm{O}_{3}$ & 7.6701 & 7.5256 & 8.0000 & -0.3299 & -0.4744 & $-4.1 \%$ & $-5.9 \%$ \\
\hline LRM & 300 & $\mathrm{BaO}$ & 0.0056 & 0.0060 & 0.0050 & 0.0006 & 0.0010 & $11.7 \%$ & $20.5 \%$ \\
\hline LRM & 300 & $\mathrm{CaO}$ & 0.5895 & 0.5786 & 0.5000 & 0.0895 & 0.0786 & $17.9 \%$ & $15.7 \%$ \\
\hline LRM & 300 & $\mathrm{Ce}_{2} \mathrm{O}_{3}$ & 0.0059 & 0.0059 & 0.0000 & 0.0059 & 0.0059 & & \\
\hline LRM & 300 & $\mathrm{Cr}_{2} \mathrm{O}_{3}$ & 0.1937 & 0.2092 & 0.2000 & -0.0063 & 0.0092 & $-3.2 \%$ & $4.6 \%$ \\
\hline LRM & 300 & $\mathrm{CuO}$ & 0.0063 & 0.0061 & 0.0000 & 0.0063 & 0.0061 & & \\
\hline LRM & 300 & $\mathrm{Fe}_{2} \mathrm{O}_{3}$ & 1.2838 & 1.2894 & 1.0000 & 0.2838 & 0.2894 & $28.4 \%$ & $28.9 \%$ \\
\hline LRM & 300 & $\mathrm{~K}_{2} \mathrm{O}$ & 1.5846 & 1.5000 & 1.5000 & 0.0846 & 0.0000 & $5.6 \%$ & $0.0 \%$ \\
\hline LRM & 300 & $\mathrm{La}_{2} \mathrm{O}_{3}$ & 0.0065 & 0.0065 & 0.0000 & 0.0065 & 0.0065 & & \\
\hline LRM & 300 & $\mathrm{Li}_{2} \mathrm{O}$ & 0.3121 & 0.3185 & 0.1000 & 0.2121 & 0.2185 & $212.1 \%$ & $218.5 \%$ \\
\hline LRM & 300 & $\mathrm{MgO}$ & 0.1001 & 0.1049 & 0.1000 & 0.0001 & 0.0049 & $0.1 \%$ & $4.9 \%$ \\
\hline LRM & 300 & $\mathrm{MnO}$ & 0.0065 & 0.0069 & 0.1000 & -0.0935 & -0.0931 & $-93.5 \%$ & $-93.1 \%$ \\
\hline LRM & 300 & $\mathrm{Na}_{2} \mathrm{O}$ & 20.6132 & 19.6805 & 20.0000 & 0.6132 & -0.3195 & $3.1 \%$ & $-1.6 \%$ \\
\hline LRM & 300 & $\mathrm{NiO}$ & 0.1723 & 0.1898 & 0.1000 & 0.0723 & 0.0898 & $72.3 \%$ & $89.8 \%$ \\
\hline LRM & 300 & $\mathrm{PbO}$ & 0.0744 & 0.0744 & 0.1000 & -0.0256 & -0.0256 & $-25.6 \%$ & $-25.6 \%$ \\
\hline LRM & 300 & $\mathrm{SO}_{4}$ & 0.2503 & 0.2503 & 0.2400 & 0.0103 & 0.0103 & $4.3 \%$ & $4.3 \%$ \\
\hline LRM & 300 & $\mathrm{SiO}_{2}$ & 53.1081 & 54.5728 & 54.3700 & -1.2619 & 0.2028 & $-2.3 \%$ & $0.4 \%$ \\
\hline LRM & 300 & $\mathrm{ThO}_{2}$ & 0.0569 & 0.0569 & 0.0000 & 0.0569 & 0.0569 & & \\
\hline LRM & 300 & $\mathrm{TiO}_{2}$ & 0.0967 & 0.1028 & 0.1000 & -0.0033 & 0.0028 & $-3.3 \%$ & $2.8 \%$ \\
\hline LRM & 300 & $\mathrm{U}_{3} \mathrm{O}_{8}$ & 0.0590 & 0.0644 & 0.0000 & 0.0590 & 0.0644 & & \\
\hline LRM & 300 & $\mathrm{ZnO}$ & 0.0062 & 0.0062 & 0.0000 & 0.0062 & 0.0062 & & \\
\hline LRM & 300 & $\mathrm{ZrO}_{2}$ & 0.9009 & 0.9009 & 1.0000 & -0.0991 & -0.0991 & $-9.9 \%$ & $-9.9 \%$ \\
\hline LRM & 300 & Sum & 97.0348 & 97.6674 & 97.4150 & -0.3802 & 0.2524 & $-0.4 \%$ & $0.3 \%$ \\
\hline
\end{tabular}


Exhibit B1. Oxide Measurements in Analytical Sequence for Samples Prepared Using the LM Method

Legend

\begin{tabular}{|c|c|c|c|}
\hline$\nabla$ & $\nabla$ & Glass ID & N Rows \\
\hline 口 & 1 & Batch 1 & 12 \\
\hline$\bullet$ & 2 & LRM(1) & 4 \\
\hline$\bullet$ & 3 & $\operatorname{LRM}(2)$ & 4 \\
\hline$\bullet$ & 4 & LRM(3) & 4 \\
\hline$\bullet$ & 5 & LRM(4) & 4 \\
\hline$\bullet$ & 6 & LRM(5) & 4 \\
\hline$\bullet$ & 7 & LRM(6) & 4 \\
\hline$\cdot$ & 8 & SB4SULFA-01 & 4 \\
\hline+ & 9 & SB4SULFA-02 & 4 \\
\hline$x$ & 10 & SB4SULFA-03 & 4 \\
\hline a & 11 & SB4SULFA-04 & 4 \\
\hline$\diamond$ & 12 & SB4SULFA-05 & 4 \\
\hline$\Delta$ & 13 & SB4SULFA-06 & 4 \\
\hline$r$ & 14 & SB4SULFA-07 & 4 \\
\hline$z$ & 15 & SB4SULFA-08 & 4 \\
\hline$\circ$ & 16 & SB4SULFA-09 & 4 \\
\hline 口 & 17 & SB4SULFA-10 & 4 \\
\hline 米 & 18 & Ustd & 12 \\
\hline
\end{tabular}

Al2O3 (wt\%) By Analytical Sequence

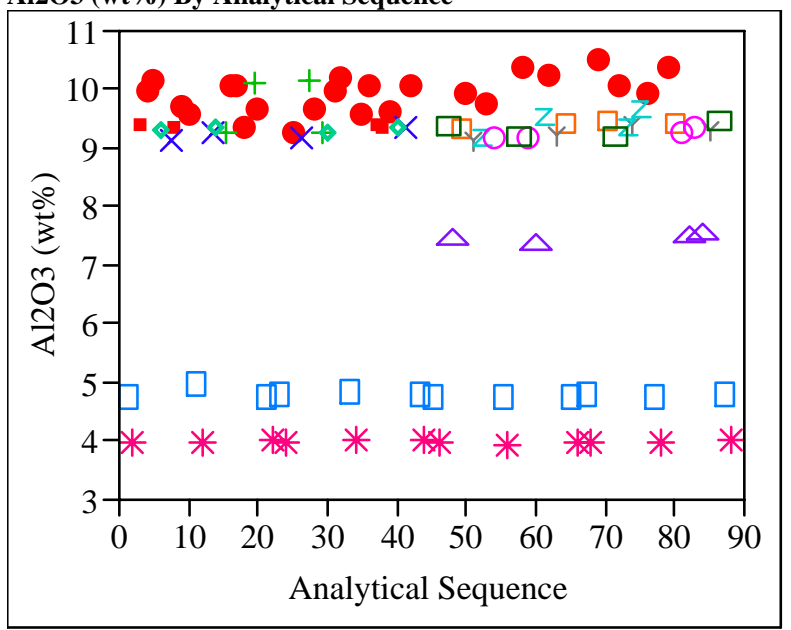

BaO (wt\%) By Analytical Sequence

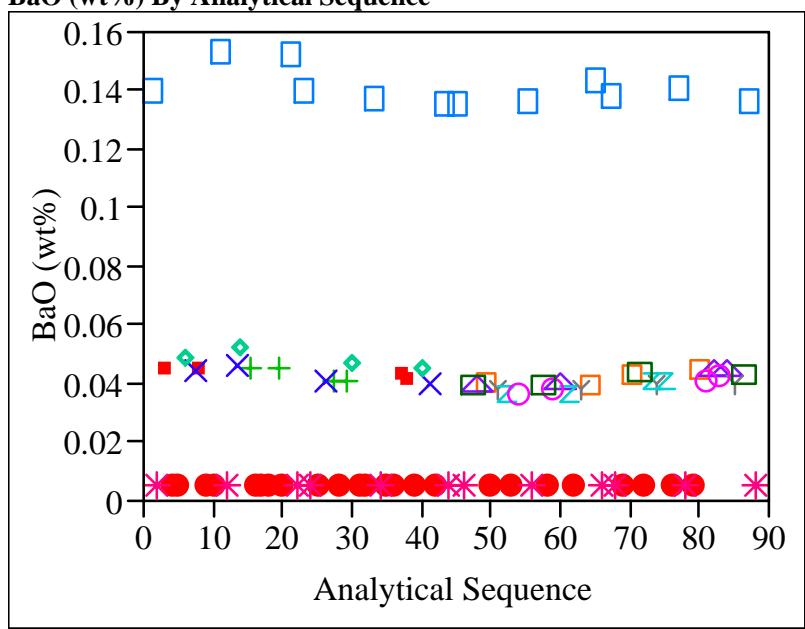

$\mathrm{CaO}$ (wt\%) By Analytical Sequence

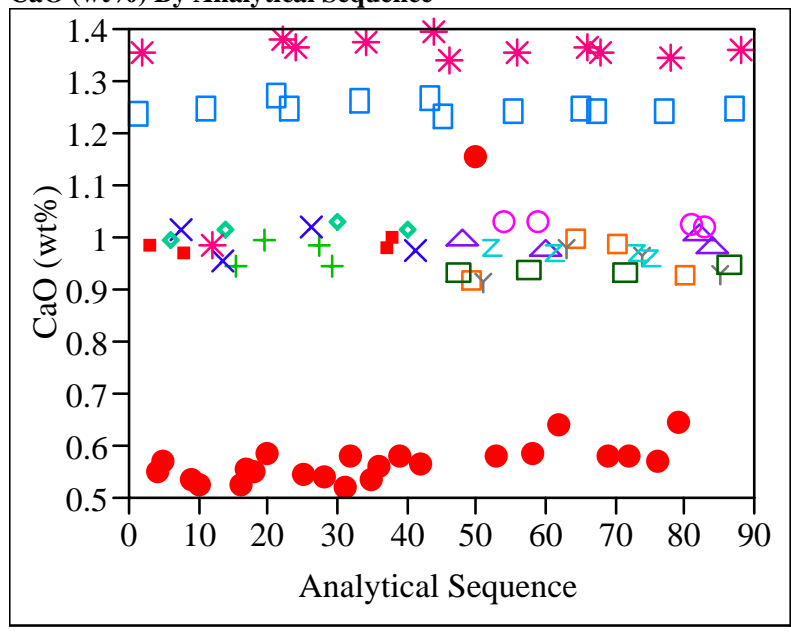

Ce2O3 (wt \%) By Analytical Sequence

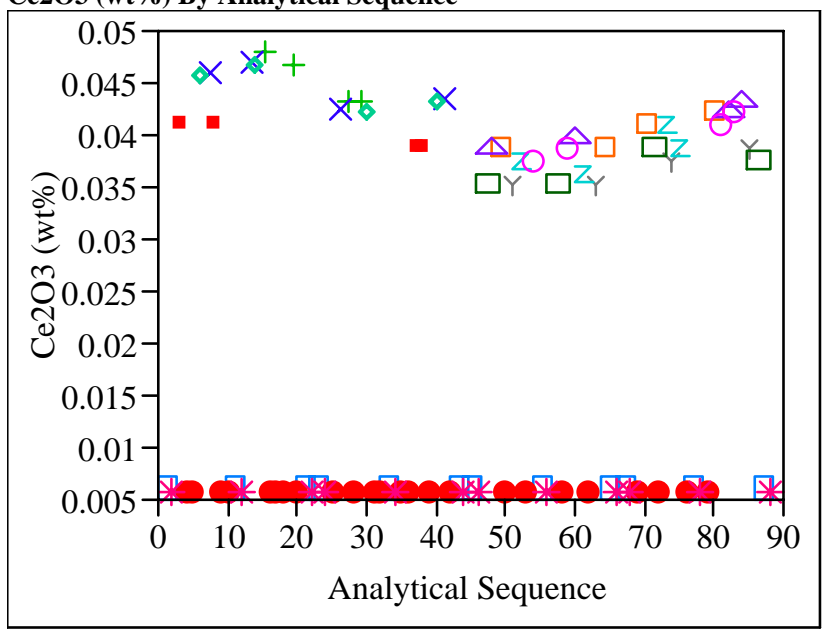


Exhibit B1. Oxide Measurements in Analytical Sequence for Samples Prepared Using the LM Method (continued)
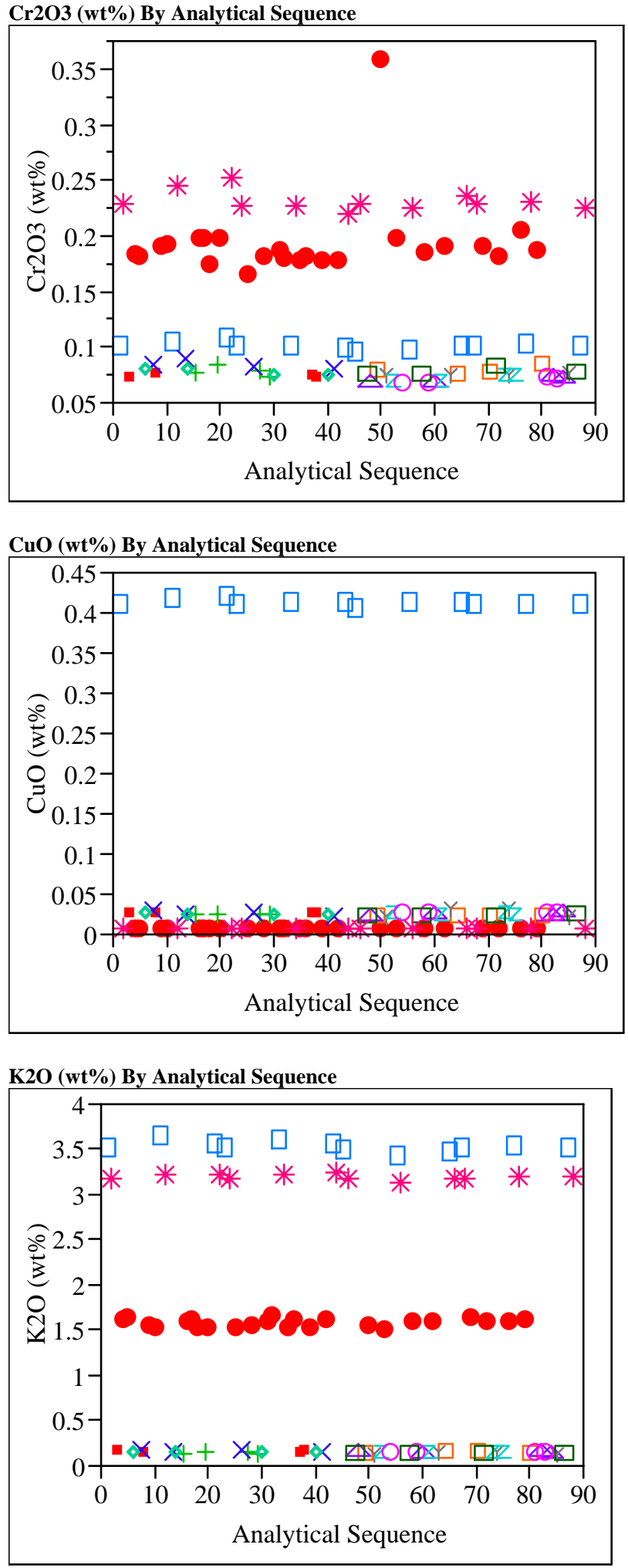

La2O3 (wt\%) By Analytical Sequence

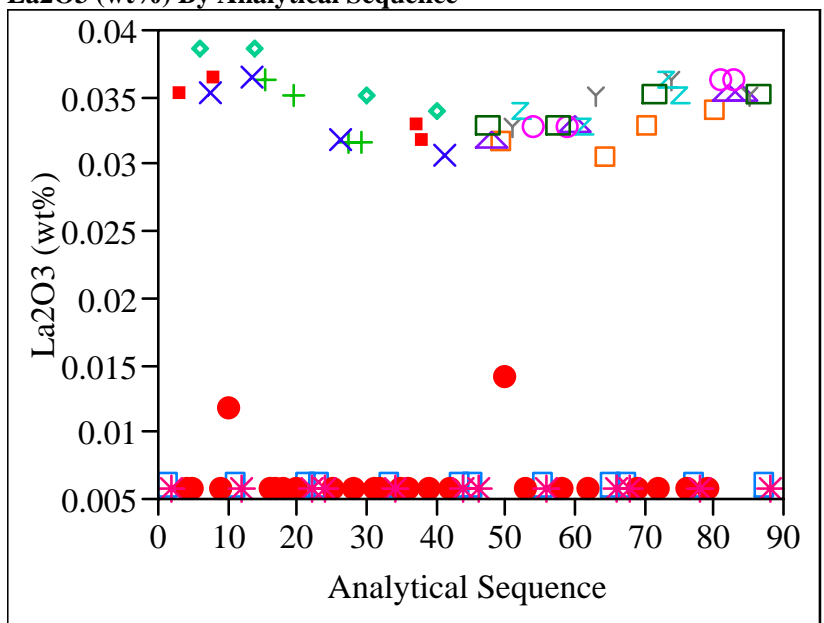

$\mathrm{MgO}$ (wt\%) By Analytical Sequence
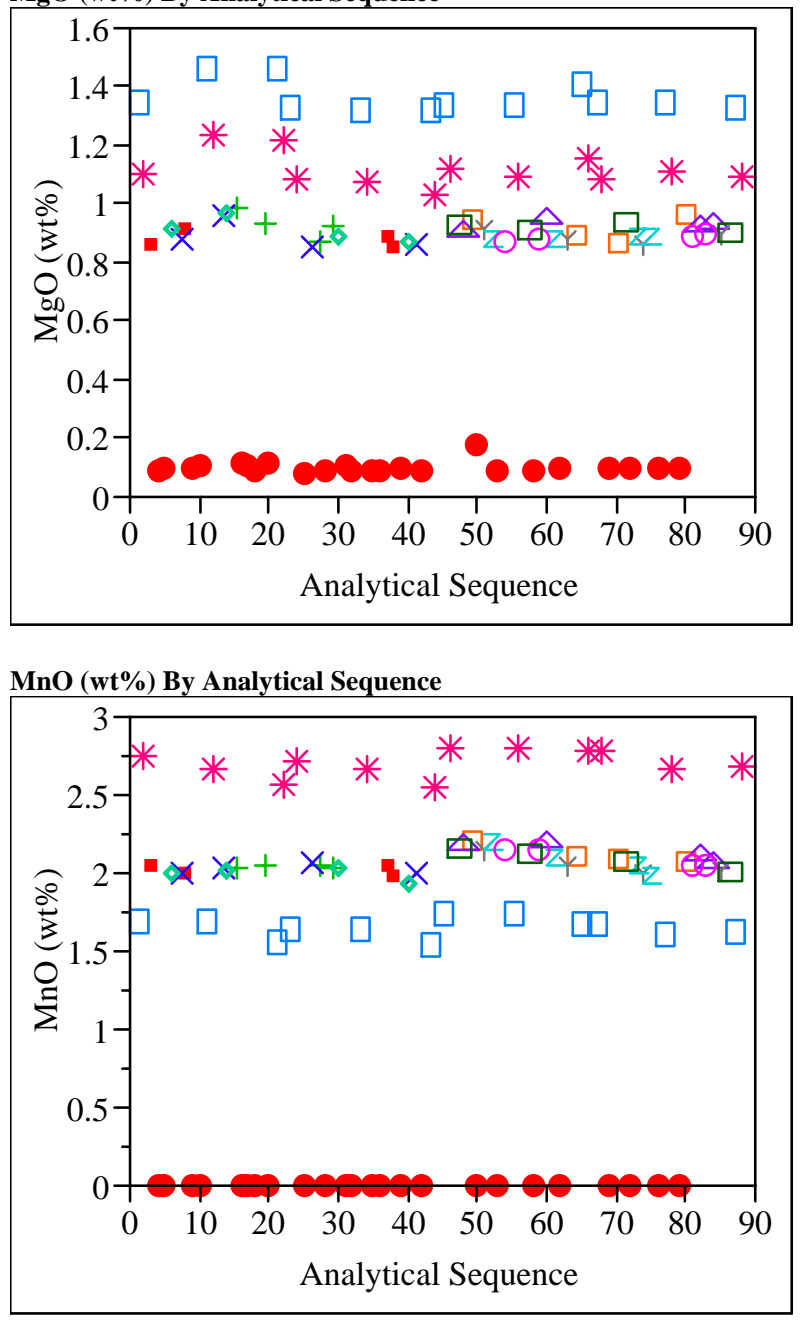
Exhibit B1. Oxide Measurements in Analytical Sequence for Samples Prepared Using the LM Method (continued)

Na2O (wt\%) By Analytical Sequence

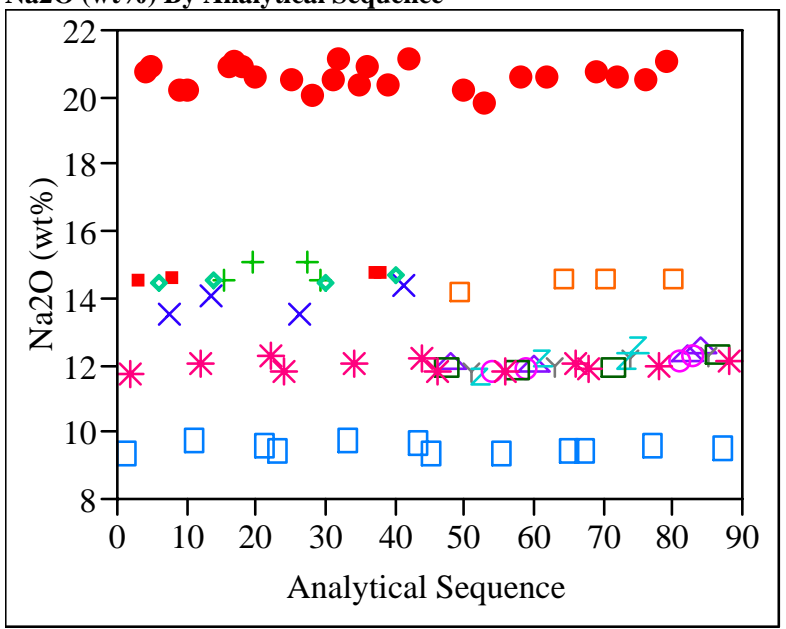

$\mathrm{NiO}$ (wt\%) By Analytical Sequence

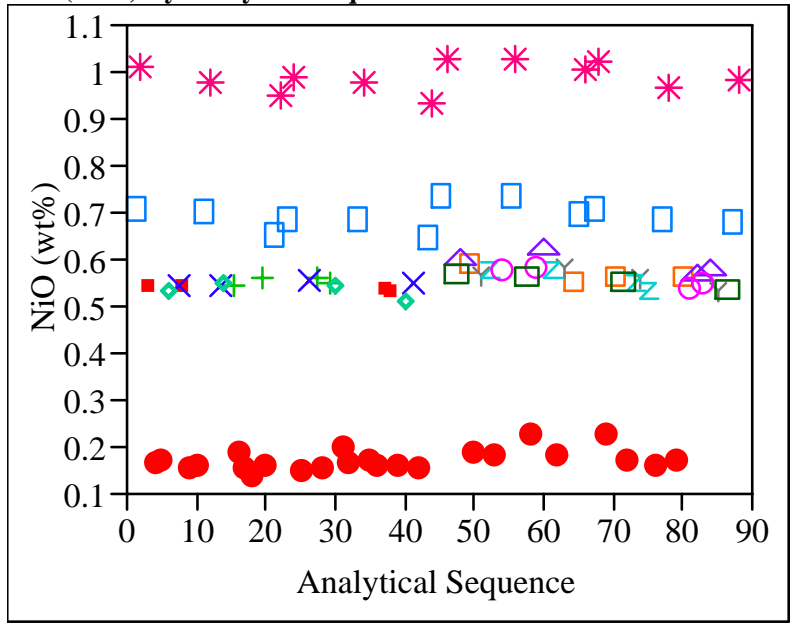

PbO (wt \%) By Analytical Sequence

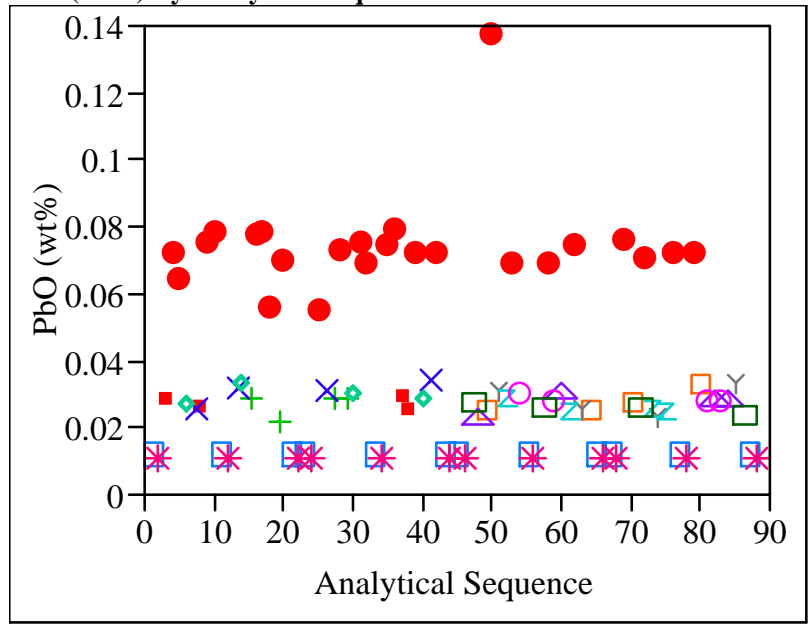

SO4 (wt\%) By Analytical Sequence

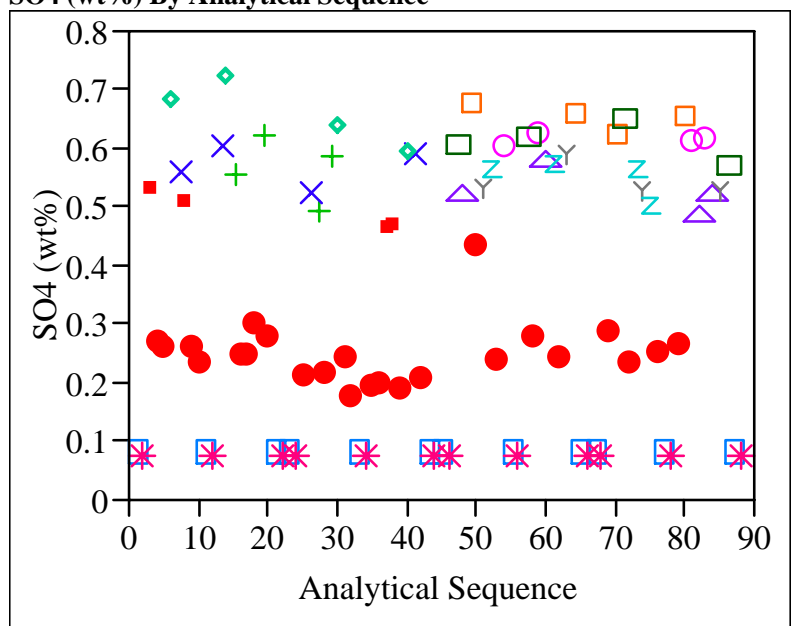

ThO2 (wt\%) By Analytical Sequence

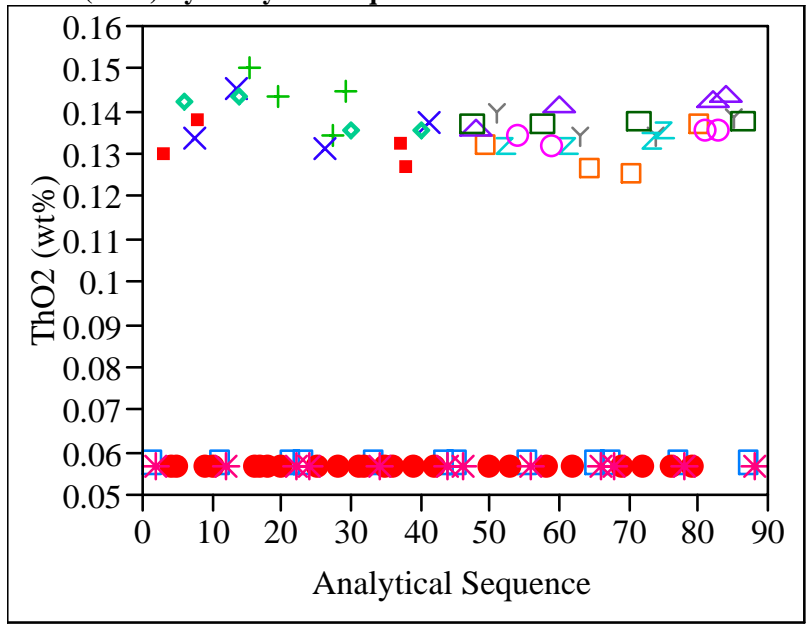

TiO2 (wt\%) By Analytical Sequence

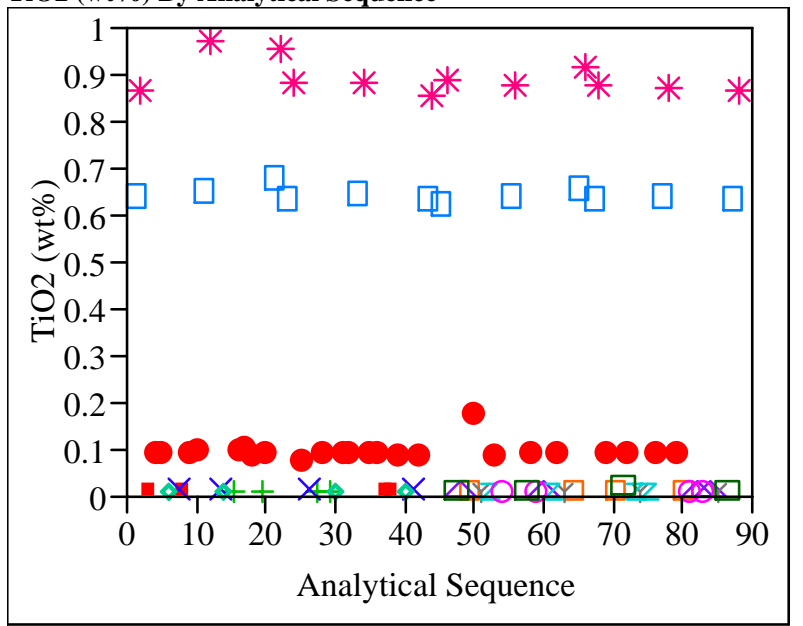


Exhibit B1. Oxide Measurements in Analytical Sequence for Samples Prepared Using the LM Method (continued)

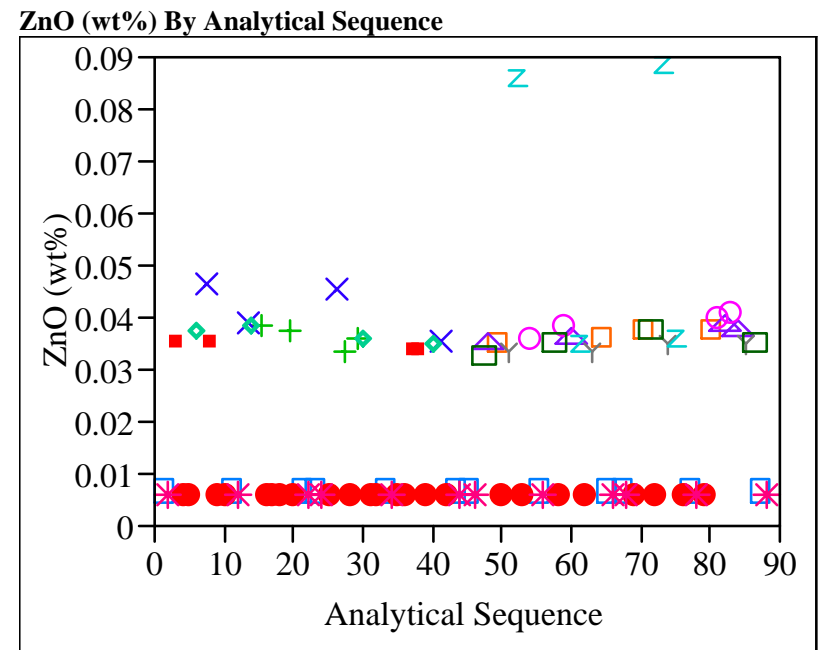

ZrO2 (wt \%) By Analytical Sequence

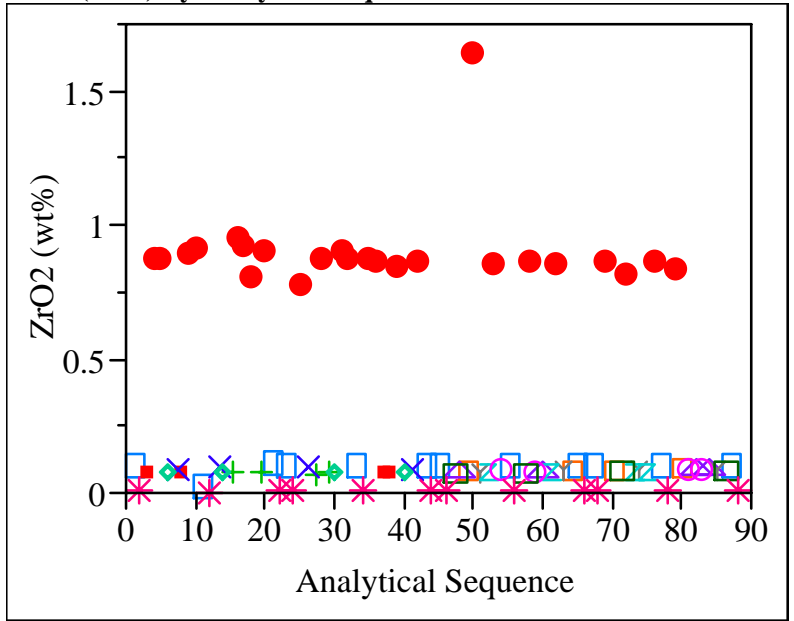


WSRC-STI-2006-00038

Revision 0

Appendix B

Exhibit B2. Oxide Measurements in Analytical Sequence for Samples

Prepared Using the PF Method

\begin{tabular}{|c|c|c|c|}
\hline $\begin{array}{l}\phi \\
\theta\end{array}$ & & Glass ID & N Rows \\
\hline 口 & 1 & Batch 1 & 12 \\
\hline - & 2 & LRM(1) & 4 \\
\hline - & 3 & LRM(2) & 4 \\
\hline$\bullet$ & 4 & LRM(3) & 4 \\
\hline - & 5 & LRM(4) & 4 \\
\hline$\bullet$ & 6 & LRM(S) & 4 \\
\hline - & 7 & LRM(O) & 4 \\
\hline$\cdot$ & 8 & SB4SULFA-01 & 4 \\
\hline+ & 9 & SB4SULFA-02 & 4 \\
\hline$x$ & 10 & SB4SULFA-03 & 4 \\
\hline 口 & 11 & SB4SULFA-04 & 4 \\
\hline$\diamond$ & 12 & SB4SULFA-05 & 4 \\
\hline$\triangle$ & 13 & SB4SULFA-06 & 4 \\
\hline$r$ & 14 & SB4SULFA-07 & 4 \\
\hline$z$ & 15 & SB4SULFA-08 & 4 \\
\hline$\circ$ & 16 & SB4SULFA-09 & 4 \\
\hline 口 & 17 & SB4SULFA-10 & 4 \\
\hline * & 18 & Ustd & 12 \\
\hline
\end{tabular}

B2O3 (wt\%) By Analytical Sequence

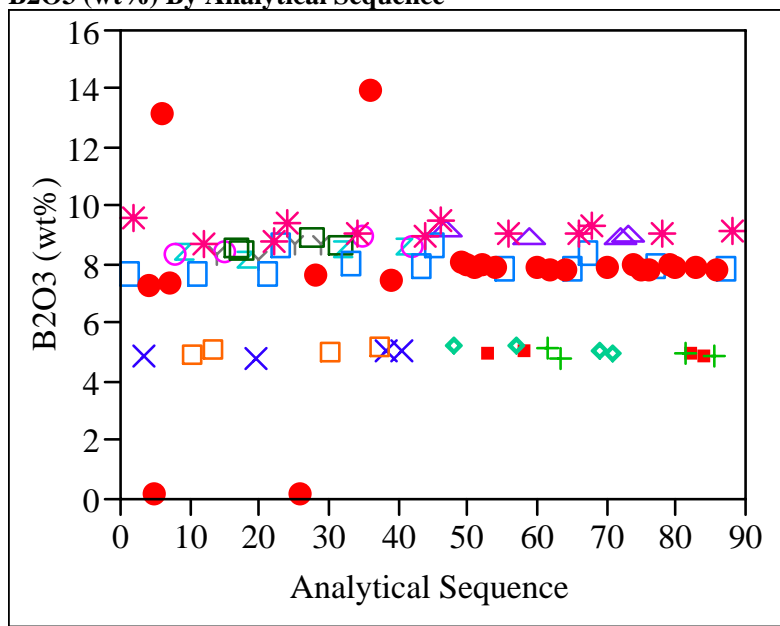

Fe2O3 (wt \%) By Analytical Sequence

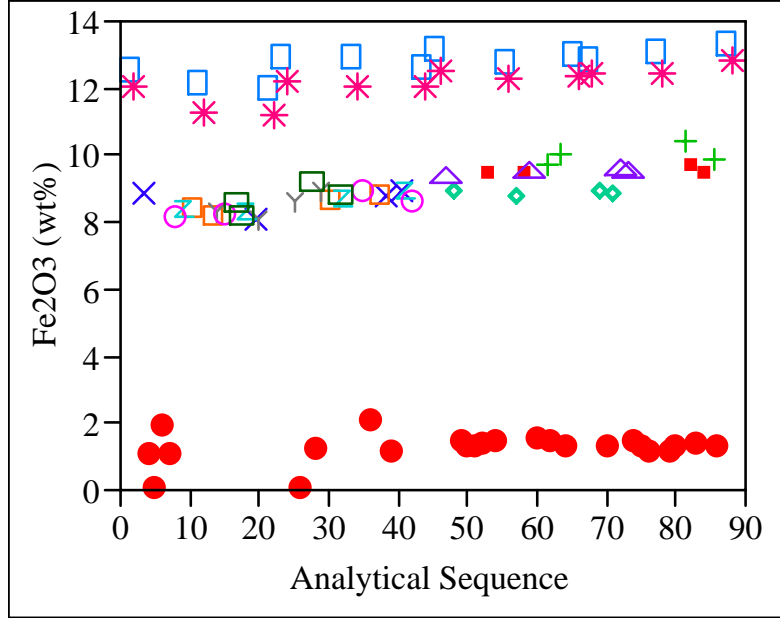

Li2O (wt\%) By Analytical Sequence

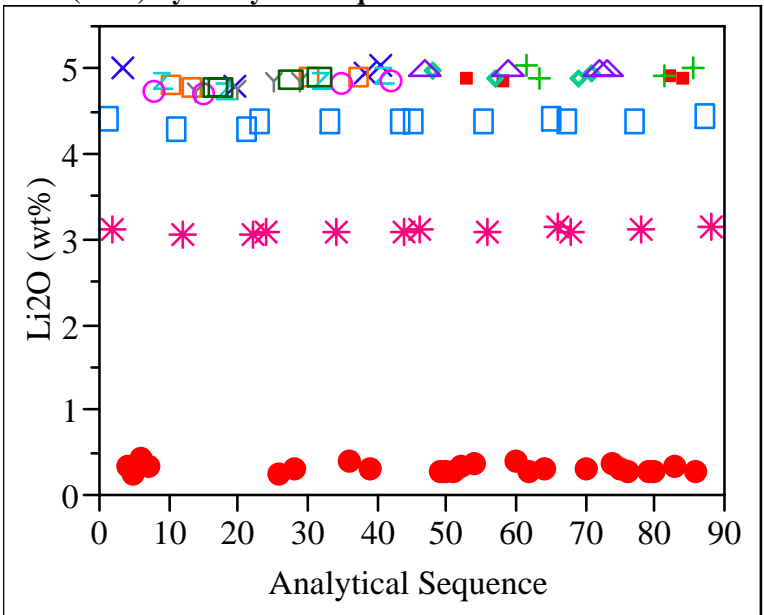

SiO2 (wt\%) By Analytical Sequence

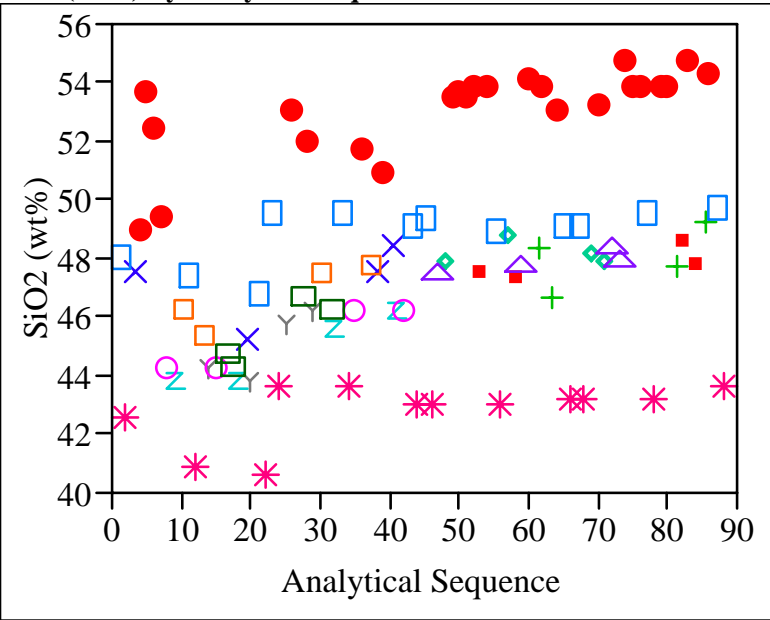

U308 (wt\%) By Analytical Sequence

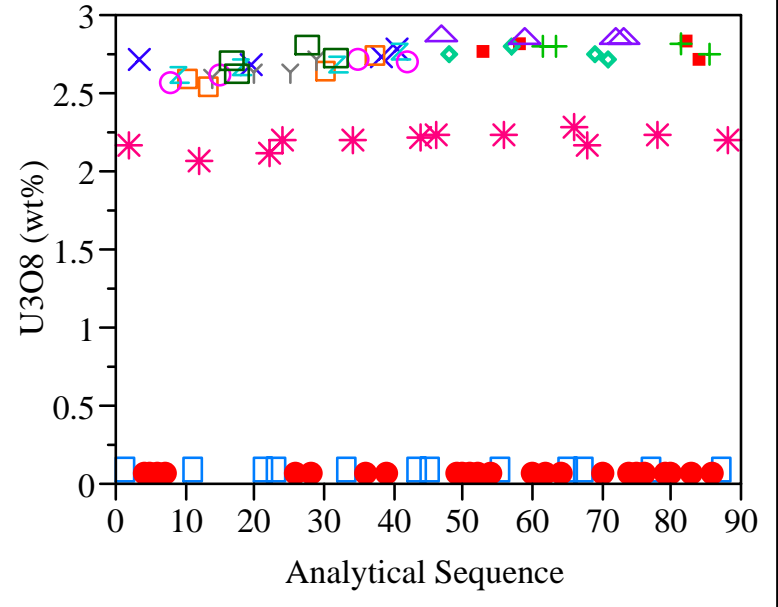


Exhibit B3. PSAL Measurements by Analytical Block for Samples of the Standard Glasses Prepared Using the LM Method

(Batch 1 - Glass \#100; U std - Glass \#200)

Study Glass \#=100

Oneway Analysis of Al2O3 (wt\%) By Blk/Sub-Blk Reference Value $=4.877 \mathrm{wt} \%$

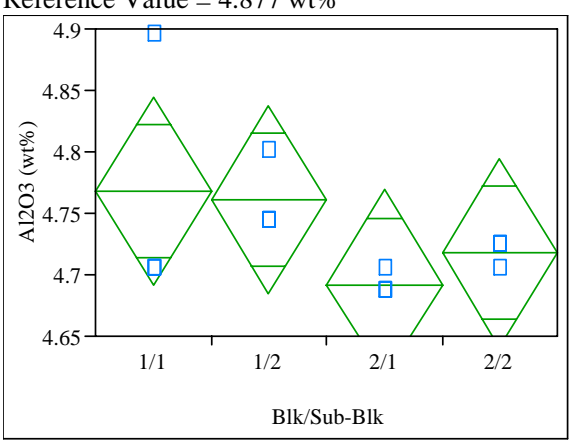

Oneway Anova

\section{Summary of Fit}

Rsquare

0.307872

Adj Rsquare

Root Mean Square Error $\quad 0.057467$

Mean of Response 4.734772

Observations (or Sum Wgts)

12

Analysis of Variance

Source DF Sum of Squares Mean Square F Ratio Prob > F $\begin{array}{lrrrrr}\text { Blk/Sub-Blk } & 3 & 0.01175194 & 0.003917 & 1.1862 & 0.3745\end{array}$

$\begin{array}{lrrr}\text { Error } & 8 & 0.02641956 & 0.003302 \\ \text { C. Total } & 11 & 0.03817150 & \end{array}$

\section{Means for Oneway Anova}

Level Number Mean Std Error Lower 95\% Upper 95\%

$\begin{array}{lrrrrr}1 / 1 & 3 & 4.76784 & 0.03318 & 4.6913 & 4.8443 \\ 1 / 2 & 3 & 4.76154 & 0.03318 & 4.6850 & 4.8380 \\ 2 / 1 & 3 & 4.69226 & 0.03318 & 4.6157 & 4.7688 \\ 2 / 2 & 3 & 4.71745 & 0.03318 & 4.6409 & 4.7940\end{array}$

Std Error uses a pooled estimate of error variance

\section{Study Glass \#=100}

Oneway Analysis of BaO (wt\%) By Blk/Sub-Blk

Reference Value $=0.151 \mathrm{wt} \%$

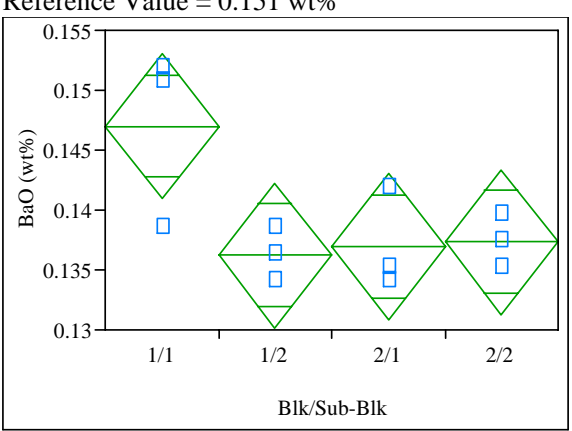

\section{Oneway Anova}

Summary of Fit

Rsquare

0.585492

$\begin{array}{ll}0.430052 \\ \text { Adj Rsquare } & 0.004558\end{array}$

Observations (or Sum Wgts) 12

\section{Analysis of Variance} $\begin{array}{llllll}\text { Blk/Sub-Blk } & 3 & 0.00023477 & 0.000078 & 3.7667 & 0.0593\end{array}$ $\begin{array}{lrrr}\text { Error } & 8 & 0.00016621 & 0.000021\end{array}$

$\begin{array}{lll}\text { C. Total } & 11 \quad 0.00040098\end{array}$

Means for Oneway Anova

Level Number Mean Std Error Lower 95\% Upper 95\% $\begin{array}{llllll}1 / 1 & 3 & 0.147006 & 0.00263 & 0.14094 & 0.15307\end{array}$ $\begin{array}{llllll}1 / 1 & 3 & 0.147006 & 0.00263 & 0.14094 & 0.15307 \\ 1 / 2 & 3 & 0.136213 & 0.00263 & 0.13014 & 0.14228\end{array}$ $\begin{array}{llllll}1 / 2 & 3 & 0.136213 & 0.00263 & 0.13014 & 0.14228 \\ 2 / 1 & 3 & 0.136957 & 0.00263 & 0.13089 & 0.14303\end{array}$ $\begin{array}{llllll}2 / 2 & 3 & 0.137330 & 0.00263 & 0.13126 & 0.14340\end{array}$
0.139376

Source DF Sum of Squares Mean Square F Ratio Prob $>$ F
Study Glass \#=100

Oneway Analysis of $\mathrm{CaO}$ (wt\%) By Blk/Sub-Blk Reference Value $=1.22 \mathrm{wt} \%$

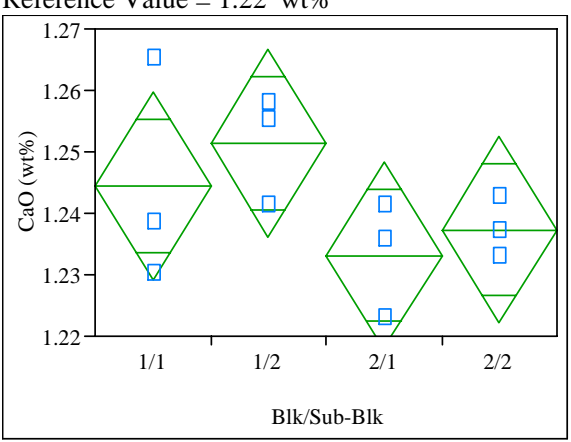

Oneway Anova

Summary of Fit

Rsquare $\quad 0.353933$

Adj Rsquare $\quad 0.111657$

Root Mean Square Error $\quad 0.01146$

Mean of Response $\quad 1.241557$

Observations (or Sum Wgts)

$$
12
$$

Analysis of Variance

Source DF Sum of Squares Mean Square F Ratio Prob > F $\begin{array}{lrrrrr}\text { Blk/Sub-Blk } & 3 & 0.00057558 & 0.000192 & 1.4609 & 0.2964\end{array}$ $\begin{array}{lrr}\text { C. Total } & 11 & 0.00105066 \\ & & \end{array}$

\section{Means for Oneway Anova}

Level Number Mean Std Error Lower 95\% Upper 95\%

$\begin{array}{llllll}1 / 1 & 3 & 1.24436 & 0.00662 & 1.2291 & 1.2596\end{array}$

$\begin{array}{llllll}1 / 2 & 3 & 1.25135 & 0.00662 & 1.2361 & 1.2666\end{array}$

$\begin{array}{llllll}2 / 1 & 3 & 1.23316 & 0.00662 & 1.2179 & 1.2484\end{array}$

$\begin{array}{llllll}2 / 2 & 3 & 1.23736 & 0.00662 & 1.2221 & 1.2526\end{array}$

Std Error uses a pooled estimate of error variance 


\section{Exhibit B3. PSAL Measurements by Analytical Block for Samples of the}

Standard Glasses Prepared Using the LM Method (continued)

(Batch 1 - Glass \#100; U std - Glass \#200)

Study Glass \#=100

Oneway Analysis of Ce2O3 (wt\%) By Blk/Sub-Blk Reference Value $=0.0 \mathrm{wt} \%$

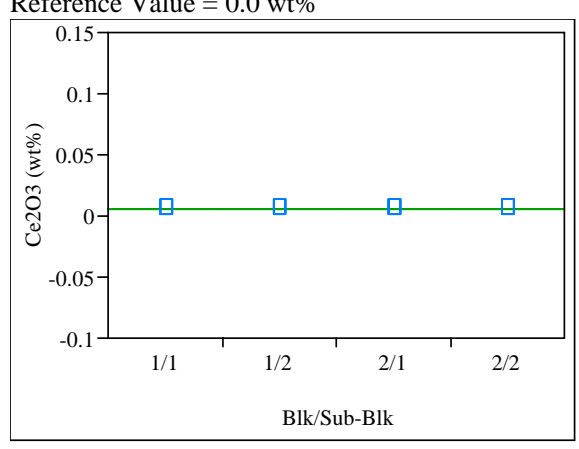

Oneway Anova

Summary of Fit

Rsquare

Adj Rsquare

Root Mean Square Error

Mean of Response

0.005857

Analysis of Variance

Source DF Sum of Squares Mean Square F Ratio Prob $>F$ $\begin{array}{ll}\text { Blk/Sub-Blk } & 3 \\ \text { Error } & 8\end{array}$

C. Tot 0

\section{Means for Oneway Anova}

$\begin{array}{lrrrrr}\text { Level } & \text { Number } & \text { Mean } & \text { Std Error } & \text { Lower 95\% } & \text { Upper 95\% } \\ 1 / 1 & 3 & 0.005857 & 0 & 0.00586 & 0.00586 \\ 1 / 2 & 3 & 0.005857 & 0 & 0.00586 & 0.00586 \\ 2 / 1 & 3 & 0.005857 & 0 & 0.00586 & 0.00586 \\ 2 / 2 & 3 & 0.005857 & 0 & 0.00586 & 0.00586\end{array}$

Std Error uses a pooled estimate of error variance

\section{Study Glass \#=100}

Oneway Analysis of Cr2O3 (wt\%) By Blk/Sub-Blk Reference Value $=0.107 \mathrm{wt} \%$

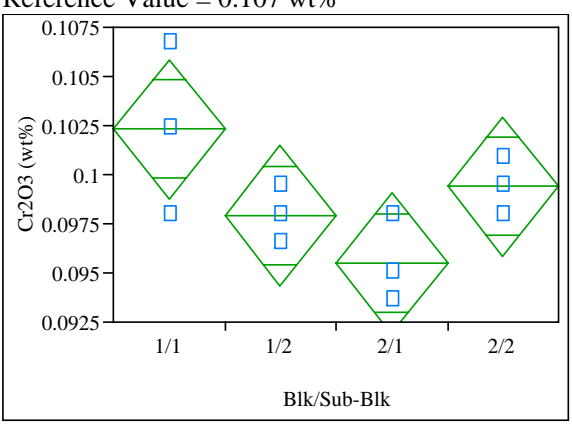

\section{Oneway Anova}

Summary of Fit

Rsquare

0.562244
0.398085

0.398085
0.002669

Mean of Response $\quad 0.09878$

Observations (or Sum Wgts)

12

Analysis of Variance

Source DF Sum of Squares Mean Square F Ratio Prob $>$ F $\begin{array}{lllllll}\text { Blk/Sub-Blk } & 3 & 0.00007317 & 0.000024 & 3.4250 & 0.0727\end{array}$ $\begin{array}{lrrrr}\text { Error } & 8 & 0.00005697 & 7.121 \mathrm{e}-6\end{array}$

\section{Means for Oneway Anova}

Level Number Mean Std Error Lower 95\% Upper 95\% $\begin{array}{llllll}1 / 1 & 3 & 0.102312 & 0.00154 & 0.09876 & 0.10586\end{array}$ $\begin{array}{llllll}1 / 2 & 3 & 0.097927 & 0.00154 & 0.09437 & 0.10148\end{array}$ $\begin{array}{llllll}2 / 1 & 3 & 0.095491 & 0.00154 & 0.09194 & 0.09904\end{array}$ $\begin{array}{llllll}2 / 2 & 3 & 0.099389 & 0.00154 & 0.09584 & 0.10294\end{array}$

Std Error uses a pooled estimate of error variance
Study Glass \#=100

Oneway Analysis of $\mathrm{CuO}$ (wt\%) By Blk/Sub-Blk

Reference Value $=0.399 \mathrm{wt} \%$

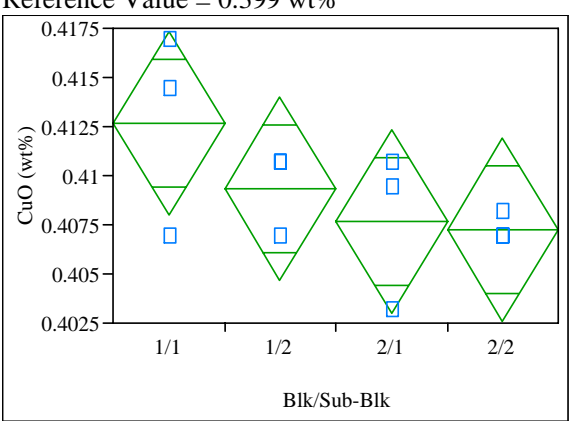

\section{Oneway Anova}

Summary of Fit

Rsquare $\quad 0.360275$

Adj Rsquare $\quad 0.120378$

Root Mean Square Error $\quad 0.003485$

Mean of Response 0.409234

Observations (or Sum Wgts)

12

\section{Analysis of Variance}

Source DF Sum of Squares Mean Square F Ratio Prob $>F$ $\begin{array}{llllll}\text { Blk/Sub-Blk } & 3 & 0.00005471 & 0.000018 & 1.5018 & 0.2865\end{array}$ $\begin{array}{lrrr}\text { Error } & 8 & 0.00009715 & 0.000012\end{array}$

\section{Means for Oneway Anova}

Level Number Mean Std Error Lower 95\% Upper 95\% $\begin{array}{llllll}1 / 1 & 3 & 0.412677 & 0.00201 & 0.40804 & 0.41732\end{array}$ $\begin{array}{llllll}1 / 2 & 3 & 0.409339 & 0.00201 & 0.40470 & 0.41398 \\ 2 / 1 & 3 & 0.407670 & 0.00201 & 0.40303 & 0.41231\end{array}$ $\begin{array}{llllll}2 / 1 & 3 & 0.407670 & 0.00201 & 0.40303 & 0.41231\end{array}$

Std Error uses a pooled estimate of error variance 


\section{Exhibit B3. PSAL Measurements by Analytical Block for Samples of the}

Standard Glasses Prepared Using the LM Method (continued)

(Batch 1 - Glass \#100; U std - Glass \#200)

Study Glass \#=100

Oneway Analysis of K2O (wt\%) By Blk/Sub-Blk Reference Value $=3.327 \mathrm{wt} \%$

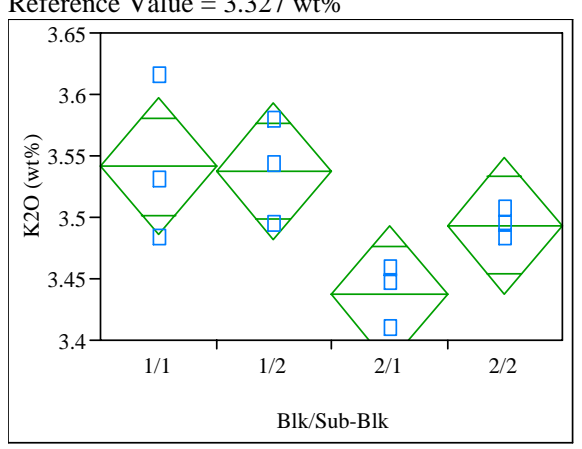

Oneway Anova

Summary of Fit

Rsquare

Adj Rsquare

Root Mean Square Error

0.601501

0.452064

Mean of Response

0.042017

Observations (or Sum Wgts)

$$
12
$$

\section{Analysis of Variance}

Source DF Sum of Squares Mean Square F Ratio Prob > F $\begin{array}{lrrrrr}\text { Blk/Sub-Blk } & 3 & 0.02131851 & 0.007106 & 4.0251 & 0.0512\end{array}$ $\begin{array}{lrr}\text { Error } & 8 & 0.01412366 \\ \text { C. Total } & 11 & 0.03544217\end{array}$

\section{Means for Oneway Anova}

Level Number Mean Std Error Lower 95\% Upper 95\% $\begin{array}{lllrrr}1 / 1 & 3 & 3.54152 & 0.02426 & 3.4856 & 3.5975\end{array}$ $\begin{array}{llllll}1 / 2 & 3 & 3.53751 & 0.02426 & 3.4816 & 3.5934\end{array}$ $\begin{array}{llllll}2 / 1 & 3 & 3.43713 & 0.02426 & 3.3812 & 3.4931 \\ 2 / 2 & 3 & 3.49334 & 0.02426 & 3.4374 & 3.5493\end{array}$

Std Error uses a pooled estimate of error variance

\section{Study Glass \#=100}

Oneway Analysis of La2O3 (wt\%) By Blk/Sub-Blk Reference Value $=0.0 \mathrm{wt} \%$

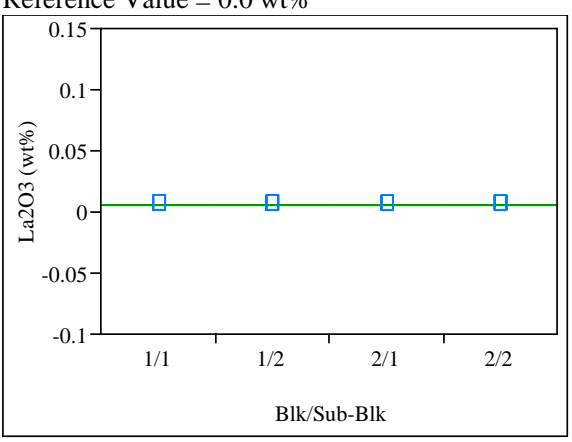

\section{Oneway Anova}

Summary of Fit

Rsquare

Adj Rsquare

Root Mean Square Error

Mean of Response

Observations (or Sum Wgts)

0.005864

Analysis of Variance

Source DF Sum of Squares Mean Square F Ratio Prob $>F$ Blk/Sub-Blk 3 Error

C. Total 11

\section{Means for Oneway Anova}

Level Number Mean Std Error Lower 95\% Upper 95\% $\begin{array}{llllll}1 / 1 & 3 & 0.005864 & 0 & 0.00586 & 0.00586\end{array}$

$1 / 2 \quad 3 \quad 30.005864$

$2 / 1 \quad 30.005864$

$2 / 2 \quad 30.005864$

$\begin{array}{ll}0 & 0.00586 \\ 0 & 0.00586 \\ 0 & 0.00586\end{array}$

$\begin{array}{ll}0 & 0.00586 \\ 0 & 0.00586\end{array}$

0.00586

0.00586

Std Error uses a pooled estimate of error variance
Study Glass \#=100

Oneway Analysis of MgO (wt \%) By Blk/Sub-Blk

Reference Value $=1.419 \mathrm{wt} \%$

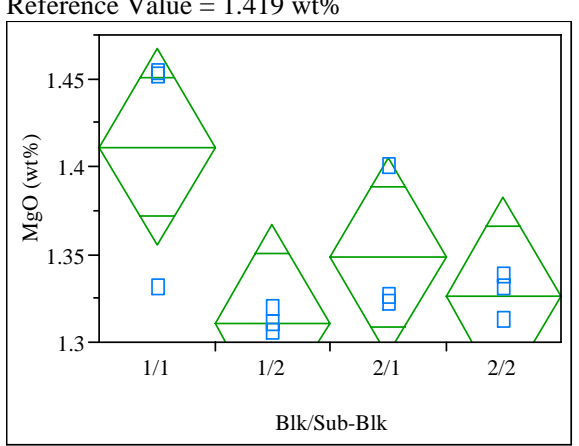

Oneway Anova

Summary of Fit

0.551571

Adj Rsquare

Root Mean Square Error $\quad 0.042148$

Mean of Response 1.349303

Observations (or Sum Wgts)

12

Analysis of Variance

Source DF Sum of Squares Mean Square F Ratio Prob $>$ F $\begin{array}{lrrrrr}\text { Blk/Sub-Blk } & 3 & 0.01748057 & 0.005827 & 3.2800 & 0.0796\end{array}$ $\begin{array}{lrr}\text { Error } & 8 & 0.01421179 \\ \text { C. Total } & 11 & 0.0316923\end{array}$

\section{Means for Oneway Anova}

Level Number Mean Std Error Lower 95\% Upper 95\% $\begin{array}{lllllr}1 / 1 & 3 & 1.41121 & 0.02433 & 1.3551 & 1.4673\end{array}$ $\begin{array}{llllll}1 / 2 & 3 & 1.31116 & 0.02433 & 1.2550 & 1.3673\end{array}$ $\begin{array}{llllll}2 / 1 & 3 & 1.34875 & 0.02433 & 1.2926 & 1.4049\end{array}$ $\begin{array}{llllll}2 / 2 & 3 & 1.32609 & 0.02433 & 1.2700 & 1.3822\end{array}$

Std Error uses a pooled estimate of error variance 


\section{Exhibit B3. PSAL Measurements by Analytical Block for Samples of the}

Standard Glasses Prepared Using the LM Method (continued)

(Batch 1 - Glass \#100; U std - Glass \#200)

Study Glass \#=100

Oneway Analysis of $\mathrm{MnO}$ (wt\%) By Blk/Sub-Blk Reference Value $=1.726 \mathrm{wt} \%$

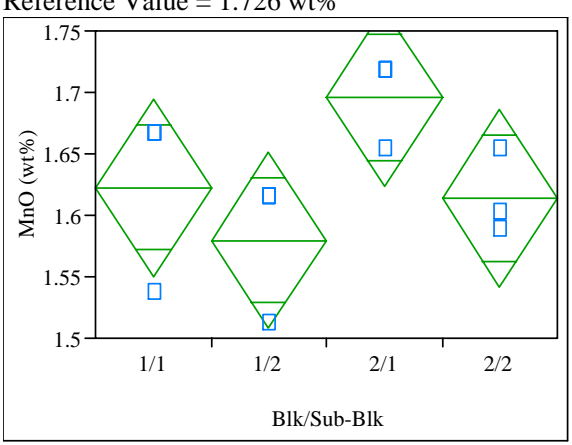

Oneway Anova

Summary of Fit

Rsquare

0.479393

Adj Rsquare

0.284165

Root Mean Square Error $\quad 0.054015$

Mean of Response 1.627988

Observations (or Sum Wgts)

12

Analysis of Variance

Source DF Sum of Squares Mean Square F Ratio Prob > F $\begin{array}{llllll}\text { Blk/Sub-Blk } & 3 & 0.02149295 & 0.007164 & 2.4556 & 0.1377\end{array}$ $\begin{array}{lrrr}\text { Error } & 8 & 0.02334076 & 0.002918\end{array}$

$\begin{array}{lll}\text { C. Total } & 11 & 0.04483372\end{array}$

\section{Means for Oneway Anova}

Level Number Mean Std Error Lower 95\% Upper 95\%

$\begin{array}{lllrrr}1 / 1 & 3 & 1.62261 & 0.03119 & 1.5507 & 1.6945\end{array}$

$\begin{array}{llllll}1 / 2 & 3 & 1.57957 & 0.03119 & 1.5077 & 1.6515\end{array}$

$\begin{array}{llllll}2 / 1 & 3 & 1.69578 & 0.03119 & 1.6239 & 1.7677 \\ 2 / 2 & 3 & 1.61400 & 0.03119 & 1.5421 & 1.6859\end{array}$

Std Error uses a pooled estimate of error variance

\section{Study Glass \#=100}

Oneway Analysis of Na2O (wt\%) By Blk/Sub-Blk Reference Value $=9.003 \mathrm{wt} \%$

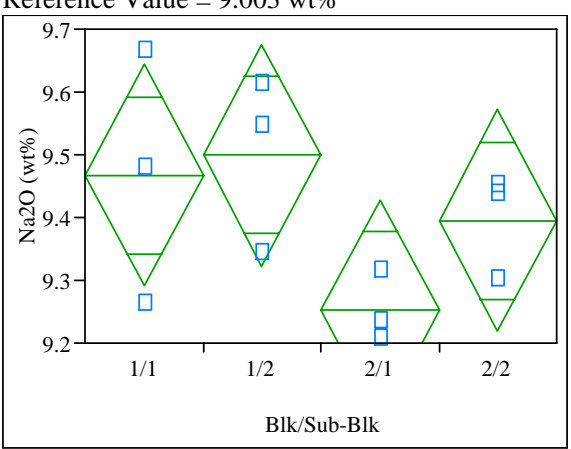

\section{Oneway Anova}

Summary of Fit

Rsquare

0.435602

Adj Rsquare

0.223953

Root Mean Square Error $\quad 0.132763$

Mean of Response 9.403423

Observations (or Sum Wgts)

12

Analysis of Variance

Source DF Sum of Squares Mean Square F Ratio Prob $>$ F $\begin{array}{lllrrr}\text { Blk/Sub-Blk } & 3 & 0.10882939 & 0.036276 & 2.0581 & 0.1843\end{array}$ \begin{tabular}{lrrrr} 
Error & 8 & 0.14100727 & 0.017626 \\
\hline C. & 11 & 0.24983666 &
\end{tabular}

\section{Means for Oneway Anova}

Level Number Mean Std Error Lower 95\% Upper 95\% $\begin{array}{llllll}1 / 1 & 3 & 9.46745 & 0.07665 & 9.2907 & 9.6442\end{array}$ $\begin{array}{llllll}1 / 2 & 3 & 9.49891 & 0.07665 & 9.3222 & 9.6757\end{array}$

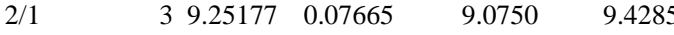
$\begin{array}{llllll}2 / 2 & 3 & 9.39556 & 0.07665 & 9.2188 & 9.5723\end{array}$

Std Error uses a pooled estimate of error variance
Study Glass \#=100

Oneway Analysis of NiO (wt\%) By Blk/Sub-Blk Reference Value $=0.751 \mathrm{wt} \%$

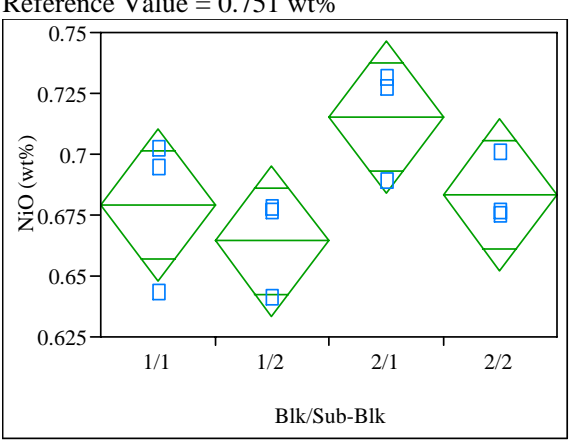

\section{Oneway Anova}

Summary of Fit

Rsquare $\quad 0.484545$

Adj Rsquare $\quad 0.29125$

Root Mean Square Error $\quad 0.023432$

Mean of Response $\quad 0.685453$

Observations (or Sum Wgts)

$$
12
$$

Analysis of Variance

Source DF Sum of Squares Mean Square F Ratio Prob > F $\begin{array}{llllll}\text { Blk/Sub-Blk } & 3 & 0.00412910 & 0.001376 & 2.5068 & 0.1329\end{array}$ $\begin{array}{lrrr}\text { Error } & 8 & 0.00439250 & 0.000549 \\ \text { C. Total } & 11 & 0.00852161 & \end{array}$

\section{Means for Oneway Anova}

Level Number Mean Std Error Lower 95\% Upper 95\% $\begin{array}{llllll}1 / 1 & 3 & 0.679091 & 0.01353 & 0.64789 & 0.71029\end{array}$ $\begin{array}{llllll}1 / 2 & 3 & 0.664245 & 0.01353 & 0.63305 & 0.69544\end{array}$ $\begin{array}{llllll}2 / 1 & 3 & 0.715145 & 0.01353 & 0.68395 & 0.74634\end{array}$ $\begin{array}{llllll}2 / 2 & 3 & 0.683333 & 0.01353 & 0.65214 & 0.71453\end{array}$

Std Error uses a pooled estimate of error variance 


\section{Exhibit B3. PSAL Measurements by Analytical Block for Samples of the}

Standard Glasses Prepared Using the LM Method (continued)

(Batch 1 - Glass \#100; U std - Glass \#200)

Study Glass \#=100

Oneway Analysis of PbO (wt\%) By Blk/Sub-Blk Reference Value $=0.0 \mathrm{wt} \%$

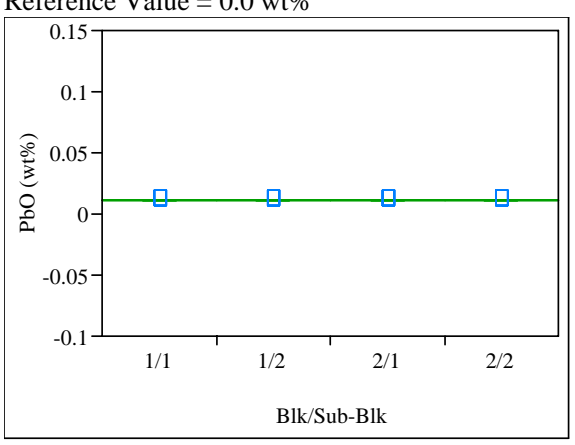

Oneway Anova
Summary of Fit

Rsquare

Adj Rsquare

Root Mean Square Error $\quad$ 2.12e-18

Mean of Response

0.010772

Observations (or Sum Wgts)

12

Analysis of Variance

Source DF Sum of Squares Mean Square F Ratio Prob $>F$ $\begin{array}{lrrrrr}\text { Blk/Sub-Blk } & 3 & 0 & 0 & 0.0000 & 1.0000\end{array}$ C. Total $11 \quad 3.6111 \mathrm{e}-35$

\section{Means for Oneway Anova}

Level Number Mean Std Error Lower 95\% Upper 95\% $\begin{array}{llllll}1 / 1 & 3 & 0.010772 & 1.227 \mathrm{e}-18 & 0.01077 & 0.01077\end{array}$ $\begin{array}{llllll}1 / 2 & 3 & 0.010772 & 1.227 \mathrm{e}-18 & 0.01077 & 0.01077\end{array}$

$\begin{array}{llllll}2 / 1 & 3 & 0.010772 & 1.227 \mathrm{e}-18 & 0.01077 & 0.01077 \\ 2 / 2 & 3 & 0.010772 & 1.227 \mathrm{e}-18 & 0.01077 & 0.01077\end{array}$

Std Error uses a pooled estimate of error variance

\section{Study Glass \#=100}

Oneway Analysis of SO4 (wt\%) By Blk/Sub-Blk Reference Value $=0.0 \mathrm{wt} \%$

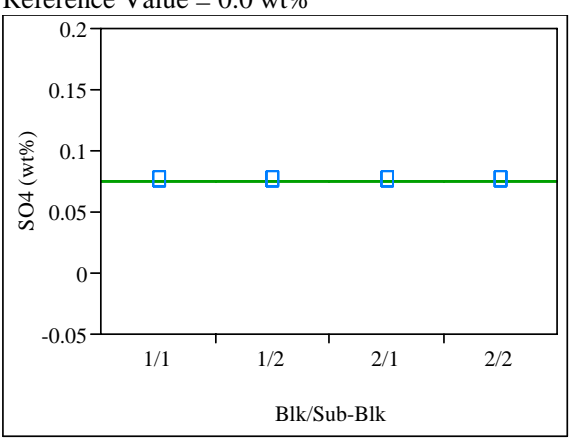

\section{Oneway Anova}

Summary of Fit

Rsquare

Adj Rsquare

Root Mean Square Error

Mean of Response

Observations (or Sum Wgts)

0.074898

Analysis of Variance

Source DF Sum of Squares Mean Square F Ratio Prob $>$ F Blk/Sub-Blk 3 Error

C. Tot

$$
\begin{array}{r}
3 \\
8 \\
11
\end{array}
$$

Means for Oneway Anova

Level Number Mean Std Error Lower 95\% Upper 95\% $\begin{array}{lllllll}1 / 1 & 3 & 0.074898 & 0 & 0.07490 & 0.07490\end{array}$ $\begin{array}{lll}1 / 2 & 3 & 0.074898\end{array}$

$\begin{array}{llll}2 / 1 & 3 & 0.074898\end{array}$

30.074898

0.07490
0.07490

$0 \quad 0.07490$

0.07490

0.07490
0.07490

0.07490

Std Error uses a pooled estimate of error variance
Study Glass \#=100

Oneway Analysis of ThO2 (wt\%) By Blk/Sub-Blk Reference Value $=0.0 \mathrm{wt} \%$

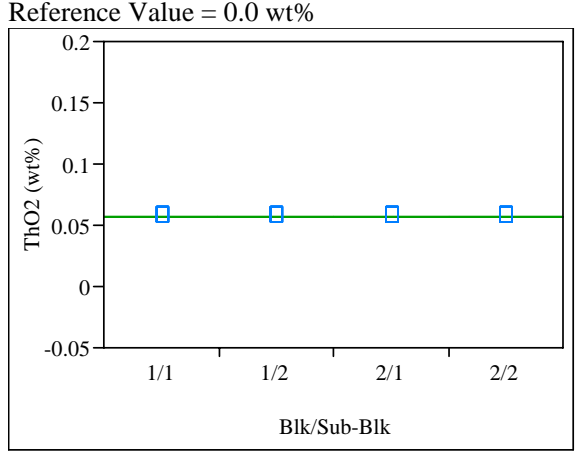

\section{Oneway Anova}

Summary of Fit

Rsquare

Adj Rsquare

Root Mean Square Error

Mean of Response

Analysis of Variance

Source DF Sum of Squares Mean Square F Ratio Prob > F Blk/Sub-Blk 3

$\begin{array}{lr}\text { Error } & 8 \\ \text { C. Total } & 11\end{array}$

\section{Means for Oneway Anova}

Level Number Mean Std Error Lower 95\% Upper 95\%

$\begin{array}{llllll}1 / 1 & 3 & 0.056895 & 0 & 0.05690 & 0.05690\end{array}$

$\begin{array}{llllll}1 / 2 & 3 & 0.056895 & 0 & 0.05690 & 0.05690\end{array}$

$\begin{array}{llllll}2 / 1 & 3 & 0.056895 & 0 & 0.05690 & 0.05690 \\ 2 / 2 & 3 & 0.056895 & 0 & 0.05690 & 0.05690\end{array}$

Std Error uses a pooled estimate of error variance 


\section{Exhibit B3. PSAL Measurements by Analytical Block for Samples of the}

Standard Glasses Prepared Using the LM Method (continued)

(Batch 1 - Glass \#100; U std - Glass \#200)

Study Glass \#=100

Oneway Analysis of TiO2 (wt\%) By Blk/Sub-Blk Reference Value $=0.677 \mathrm{wt} \%$

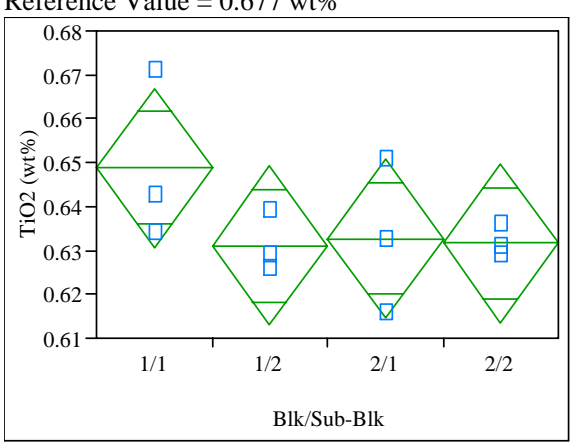

Oneway Anova

Summary of Fit

Rsquare

0.308696

Adj Rsquare

0.308696

Root Mean Square Error $\quad 0.013577$

Mean of Response 0.636064

Observations (or Sum Wgts)

12

Source DF Sum of Squares Mean Square F Ratio Prob $>$ F $\begin{array}{llllll}\text { Blk/Sub-Blk } & 3 & 0.00065846 & 0.000219 & 1.1908 & 0.3730\end{array}$ $\begin{array}{lrr}\text { Error } & 8 & 0.00147458 \\ \text { C. Total } & 11 & 0.00213304\end{array}$

\section{Means for Oneway Anova}

Level Number Mean Std Error Lower 95\% Upper 95\%

$\begin{array}{llllll}1 / 1 & 3 & 0.648852 & 0.00784 & 0.63078 & 0.66693\end{array}$

$\begin{array}{llllll}1 / 2 & 3 & 0.631060 & 0.00784 & 0.61298 & 0.64914\end{array}$

$\begin{array}{llllll}2 / 1 & 3 & 0.632728 & 0.00784 & 0.61465 & 0.65080\end{array}$

$\begin{array}{llllll}2 / 2 & 3 & 0.631616 & 0.00784 & 0.61354 & 0.64969\end{array}$

Std Error uses a pooled estimate of error variance

\section{Study Glass \#=100}

Oneway Analysis of $\mathrm{ZnO}$ (wt\%) By Blk/Sub-Blk

Reference Value $=0.0 \mathrm{wt} \%$

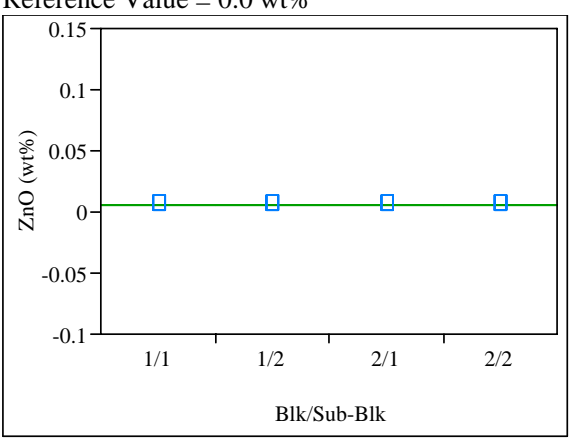

\section{Oneway Anova}

Summary of Fit

Rsquare

Adj Rsquare

Root Mean Square Error

Mean of Response

224

Observations (or Sum Wgts)

12

\section{Analysis of Variance}

Source DF Sum of Squares Mean Square F Ratio Prob $>$ F Blk/Sub-Blk 3 Error

C. Total 11

\section{Means for Oneway Anova}

Level Number Mean Std Error Lower 95\% Upper 95\% $\begin{array}{llllll}1 / 1 & 3 & 0.006224 & 0 & 0.00622 & 0.00622\end{array}$

$\begin{array}{lll}1 / 2 & 3 & 0.006224\end{array}$

$2 / 1 \quad 30.006224$

30.006224

0.00622
0.00622

$\begin{array}{ll}0 & 0.00622 \\ 0 & 0.00622\end{array}$

0.00622

0.00622

Std Error uses a pooled estimate of error variance
Study Glass \#=100

Oneway Analysis of ZrO2 (wt\%) By Blk/Sub-Blk Reference Value $=0.098 \mathrm{wt} \%$

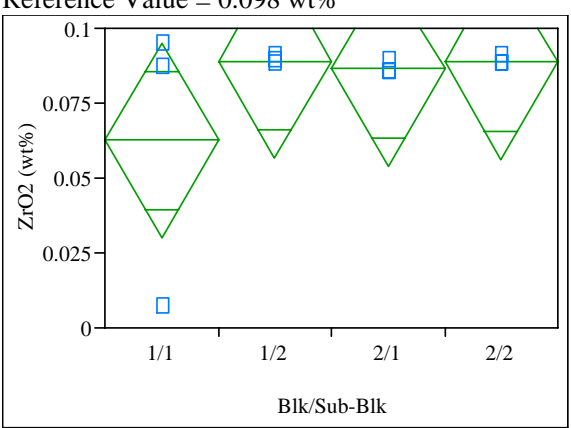

\section{Oneway Anova}

Summary of Fit

Rsquare

0.238067

Adj Rsquare

$-0.04766$

Root Mean Square Error $\quad 0.024311$

Mean of Response 0.081723

Observations (or Sum Wgts) 12

\section{Analysis of Variance}

Source DF Sum of Squares Mean Square F Ratio Prob > F $\begin{array}{llllll}\text { Blk/Sub-Blk } & 3 & 0.00147737 & 0.000492 & 0.8332 & 0.5122\end{array}$ $\begin{array}{lrrr}\text { Error } & 8 & 0.00472830 & 0.000591\end{array}$

C. Total $11 \quad 0.0062056$

Means for Oneway Anova

Level Number Mean Std Error Lower 95\% Upper 95\% $\begin{array}{llllll}1 / 1 & 3 & 0.062587 & 0.01404 & 0.03022 & 0.09495\end{array}$ $\begin{array}{llllll}1 / 2 & 3 & 0.062587 & 0.01404 & 0.03022 & 0.09495 \\ 1 / 2 & 3 & 0.089153 & 0.01404 & 0.05679 & 0.12152\end{array}$ $\begin{array}{llllll}1 / 2 & 3 & 0.089153 & 0.01404 & 0.05679 & 0.12152 \\ 2 / 1 & 3 & 0.086451 & 0.01404 & 0.05408 & 0.11882\end{array}$ $\begin{array}{llllll}2 / 2 & 3 & 0.088703 & 0.01404 & 0.05634 & 0.12107\end{array}$

Std Error uses a pooled estimate of error variance 


\section{Exhibit B3. PSAL Measurements by Analytical Block for Samples of the}

Standard Glasses Prepared Using the LM Method (continued)

(Batch 1 - Glass \#100; U std - Glass \#200)

Study Glass \#=200

Oneway Analysis of Al2O3 (wt\%) By Blk/Sub-Blk Reference Value $=4.1 \mathrm{wt} \%$

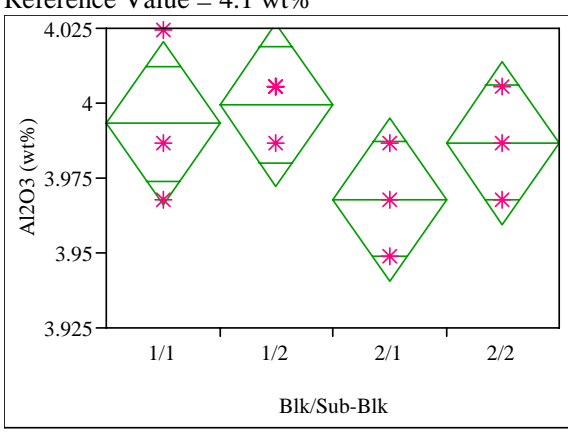

\section{Oneway Anova}

Summary of Fit

$\begin{array}{lr}\text { Rsquare } & 0.333333 \\ \text { Adj Rsquare } & 0.083333 \\ \text { Root Mean Square Error } & 0.020409 \\ \text { Mean of Response } & 3.986845 \\ \text { Observations (or Sum Wgts) } & 12\end{array}$

Analysis of Variance

Source DF Sum of Squares Mean Square F Ratio Prob > F $\begin{array}{llllll}\text { Blk/Sub-Blk } & 3 & 0.00166610 & 0.000555 & 1.3333 & 0.3300\end{array}$ $\begin{array}{lrrr}\text { Error } & 8 & 0.00333220 & 0.000417 \\ \text { C. Total } & 11 & 0.00499829 & \end{array}$

\section{Means for Oneway Anova}

Level Number Mean Std Error Lower 95\% Upper 95\% $\begin{array}{lllllr}1 / 1 & 3 & 3.99314 & 0.01178 & 3.9660 & 4.0203\end{array}$ $\begin{array}{llllll}1 / 2 & 3 & 3.99944 & 0.01178 & 3.9723 & 4.0266\end{array}$ $\begin{array}{llllll}2 / 1 & 3 & 3.96795 & 0.01178 & 3.9408 & 3.9951 \\ 2 / 2 & 3 & 3.98685 & 0.01178 & 3.9597 & 4.0140\end{array}$

Std Error uses a pooled estimate of error variance

\section{Study Glass \#=200}

Oneway Analysis of BaO (wt\%) By Blk/Sub-Blk Reference Value $=0.0 \mathrm{wt} \%$

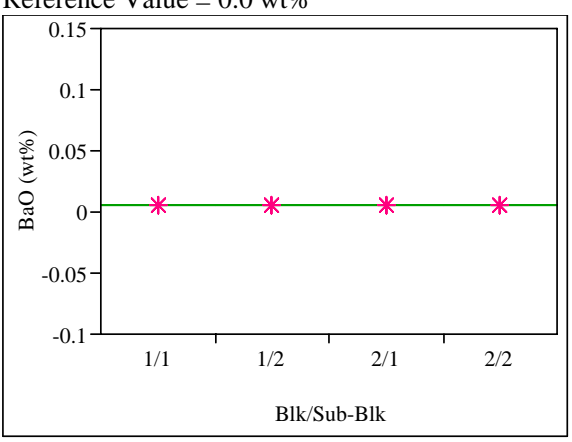

\section{Oneway Anova}

Summary of Fit

\section{Rsquare}

Adj Rsquare

Root Mean Square Error

Mean of Response

Observations (or Sum Wgts)

0.005583

Analysis of Variance

Source DF Sum of Squares Mean Square F Ratio Prob > F $\begin{array}{lrrr}\text { Source } & \text { DF } & \text { Sum of Squares } & \text { Mean Square } \\ \text { Blk/Sub-Blk } & 3 & 0 & 0 \\ \text { Error } & 8 & 0 & 0\end{array}$

Error$$
\begin{array}{r}
8 \\
11
\end{array}
$$

\section{Means for Oneway Anova}

Level Number Mean Std Error Lower 95\% Upper 95\% $\begin{array}{llllll}1 / 1 & 3 & 0.005583 & 0 & 0.00558 & 0.00558\end{array}$ $\begin{array}{llllll}1 / 2 & 3 & 0.005583 & 0 & 0.00558 & 0.00558 \\ 1 / 2 & 3 & 0.005583 & 0 & 0.00558 & 0.00558 \\ 2 / 1 & 3 & 0.005583 & 0 & 0.00558 & 0.00558\end{array}$

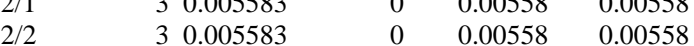

Std Error uses a pooled estimate of error variance

\section{Study Glass \#=200}

Oneway Analysis of CaO (wt\%) By Blk/Sub-Blk Reference Value $=1.301 \mathrm{wt} \%$

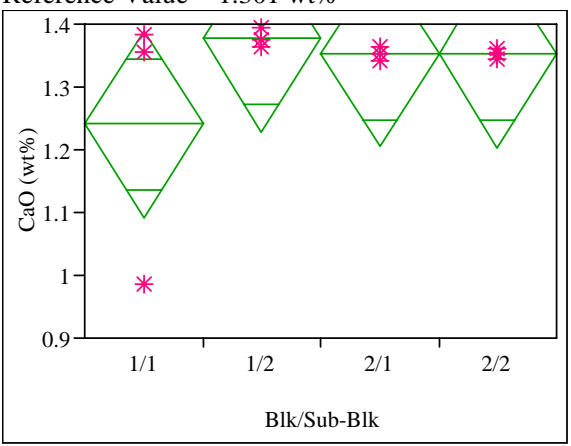

\section{Oneway Anova}

Summary of Fit

$\begin{array}{lr}\text { Rsquare } & 0.252839 \\ \text { Adj Rsquare } & -0.02735 \\ \text { Root Mean Square Error } & 0.111387 \\ \text { Mean of Response } & 1.330639 \\ \text { Observations (or Sum Wgts) } & 12\end{array}$

1.330639

Analysis of Variance

Source DF Sum of Squares Mean Square F Ratio Prob $>$ F $\begin{array}{llllll}\text { Blk/Sub-Blk } & 3 & 0.03358865 & 0.011196 & 0.9024 & 0.4813\end{array}$ $\begin{array}{lrrr}\text { Error } & 8 & 0.09925716 & 0.012407 \\ \text { C. Total } & 11 & 0.13284581 & \end{array}$

$\begin{array}{lll}\text { C. Total } & 11 & 0.1328458\end{array}$

Level Number Mean Std Error Lower 95\% Upper 95\% $\begin{array}{llllll}1 / 1 & 3 & 1.24062 & 0.06431 & 1.0923 & 1.3889\end{array}$

$\begin{array}{llllll}1 / 2 & 3 & 1.37681 & 0.06431 & 1.2285 & 1.5251\end{array}$

$\begin{array}{llllll}2 / 1 & 3 & 1.35303 & 0.06431 & 1.2047 & 1.5013\end{array}$

$\begin{array}{llllll}2 / 2 & 3 & 1.35209 & 0.06431 & 1.2038 & 1.5004\end{array}$

Std Error uses a pooled estimate of error variance 


\section{Exhibit B3. PSAL Measurements by Analytical Block for Samples of the}

Standard Glasses Prepared Using the LM Method (continued)

(Batch 1 - Glass \#100; U std - Glass \#200)

Study Glass \#=200

Oneway Analysis of Ce2O3 (wt\%) By Blk/Sub-Blk Reference Value $=0.0 \mathrm{wt} \%$

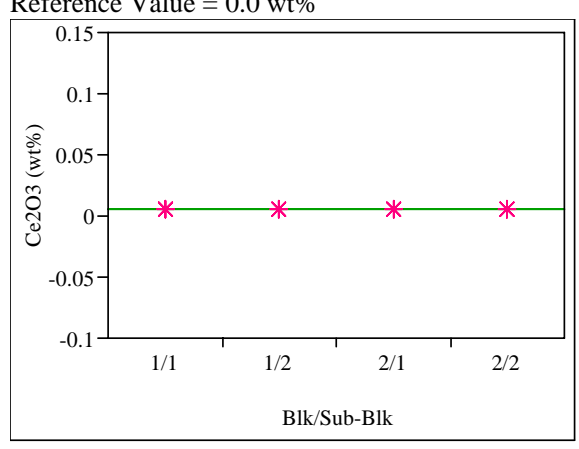

Oneway Anova

Summary of Fit

Rsquare

Adj Rsquare

Root Mean Square Error

Mean of Response

5857

Observations (or Sum Wgts)

0.005857

Analysis of Variance

Source DF Sum of Squares Mean Square F Ratio Prob $>F$ Blk/Sub-Blk 3 Error $\begin{array}{lcl}3 & 0 & 0 \\ 8 & 0 & 0\end{array}$

C. To

0

\section{Means for Oneway Anova}

$\begin{array}{lrrrrr}\text { Level Number } & \text { Mean } & \text { Std Error } & \text { Lower 95\% } & \text { Upper 95\% } \\ 1 / 1 & 3 & 0.005857 & 0 & 0.00586 & 0.00586 \\ 1 / 2 & 3 & 0.005857 & 0 & 0.00586 & 0.00586 \\ 2 / 1 & 3 & 0.005857 & 0 & 0.00586 & 0.00586 \\ 2 / 2 & 3 & 0.005857 & 0 & 0.00586 & 0.00586\end{array}$

Std Error uses a pooled estimate of error variance

\section{Study Glass \#=200}

Oneway Analysis of Cr2O3 (wt\%) By Blk/Sub-Blk

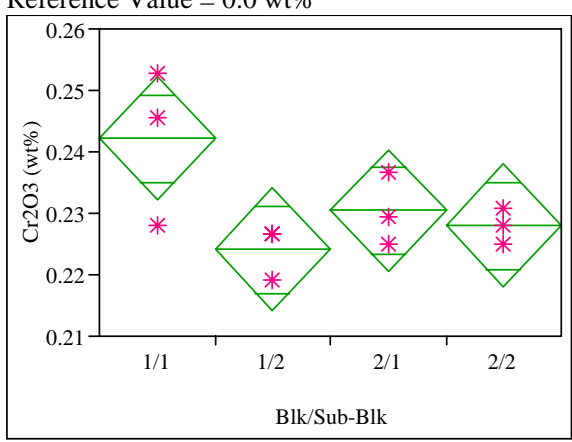

\section{Oneway Anova}

Summary of Fit

Rsquare

0.547088

Adj Rsquare

0.547088

Root Mean Square Error $\quad 0.007488$

0.007488
0.231176

Observations (or Sum Wgts)

12

Analysis of Variance

Source DF Sum of Squares Mean Square F Ratio Prob > F $\begin{array}{llllll}\text { Blk/Sub-Blk } & 3 & 0.00054190 & 0.000181 & 3.2212 & 0.0826\end{array}$ $\begin{array}{lrr}\text { C. Total } & 11 & 0.00099052\end{array}$ 0.000056

\section{Means for Oneway Anova}

Level Number Mean Std Error Lower 95\% Upper 95\% $\begin{array}{llllll}1 / 1 & 3 & 0.242138 & 0.00432 & 0.23217 & 0.25211\end{array}$ $\begin{array}{llllll}1 / 2 & 3 & 0.224112 & 0.00432 & 0.21414 & 0.23408\end{array}$

$\begin{array}{llllll}2 / 1 & 3 & 0.230446 & 0.00432 & 0.22048 & 0.24042\end{array}$

$\begin{array}{llllll}2 / 2 & 3 & 0.228010 & 0.00432 & 0.21804 & 0.23798\end{array}$

Std Error uses a pooled estimate of error variance Reference Value $=0.0 \mathrm{wt} \%$
Study Glass \#=200

Oneway Analysis of $\mathrm{CuO}$ (wt\%) By Blk/Sub-Blk

Reference Value $=0.0 \mathrm{wt} \%$

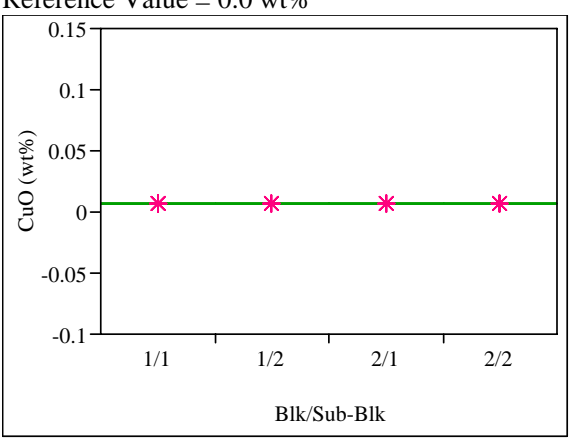

\section{Oneway Anova}

Summary of Fit

Rsquare

Adj Rsquare

Root Mean Square Error

Mean of Response

Observations (or Sum Wgts) 12

\section{Analysis of Variance}

Source DF Sum of Squares Mean Square F Ratio Prob > F

Blk/Sub-Blk 3

$\begin{array}{lr}\text { Error } & 8 \\ \text { C. Total } & 11\end{array}$

\section{Means for Oneway Anova}

Level Number Mean Std Error Lower 95\% Upper 95\%

$\begin{array}{llllll}1 / 1 & 3 & 0.006259 & 0 & 0.00626 & 0.00626\end{array}$

$\begin{array}{llllll}1 / 2 & 3 & 0.006259 & 0 & 0.00626 & 0.00626\end{array}$

$\begin{array}{llllll}2 / 1 & 3 & 0.006259 & 0 & 0.00626 & 0.00626\end{array}$

$\begin{array}{llllll}2 / 2 & 3 & 0.006259 & 0 & 0.00626 & 0.00626\end{array}$

Std Error uses a pooled estimate of error variance 


\section{Exhibit B3. PSAL Measurements by Analytical Block for Samples of the}

Standard Glasses Prepared Using the LM Method (continued)

(Batch 1 - Glass \#100; U std - Glass \#200)

Study Glass \#=200

Oneway Analysis of K2O (wt\%) By Blk/Sub-Blk Reference Value $=2.999 \mathrm{wt} \%$

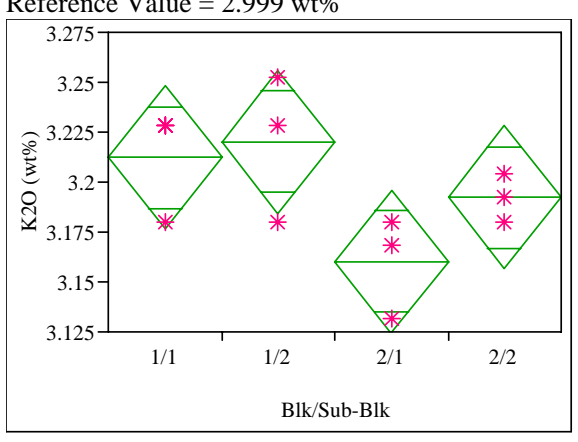

\section{Oneway Anova}

Summary of Fit

Rsquare

Adj Rsquare

\subsection{9}

Root Mean Square Erro

0.350394

Mean of Response$$
3.196205
$$

Observations (or Sum Wgts)

Analysis of Variance

Source DF Sum of Squares Mean Square F Ratio Prob $>$ F $\begin{array}{llllll}\text { Blk/Sub-Blk } & 3 & 0.00648141 & 0.002160 & 2.9778 & 0.0965\end{array}$ $\begin{array}{llll}\text { Error } & 8 & 0.00580424 & 0.000726\end{array}$

$\begin{array}{lll}\text { C. Total } & 11 & 0.01228565\end{array}$

Means for Oneway Anova

Level Number Mean Std Error Lower 95\% Upper 95\%

$\begin{array}{llllll}1 / 1 & 3 & 3.21227 & 0.01555 & 3.1764 & 3.2481\end{array}$

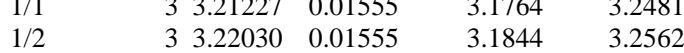

$\begin{array}{llllll}2 / 1 & 3 & 3.16007 & 0.01555 & 3.1242 & 3.1959\end{array}$

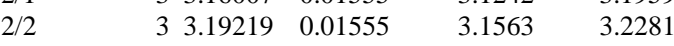

Std Error uses a pooled estimate of error variance

\section{Study Glass \#=200}

Oneway Analysis of La2O3 (wt\%) By Blk/Sub-Blk Reference Value $=0.0 \mathrm{wt} \%$

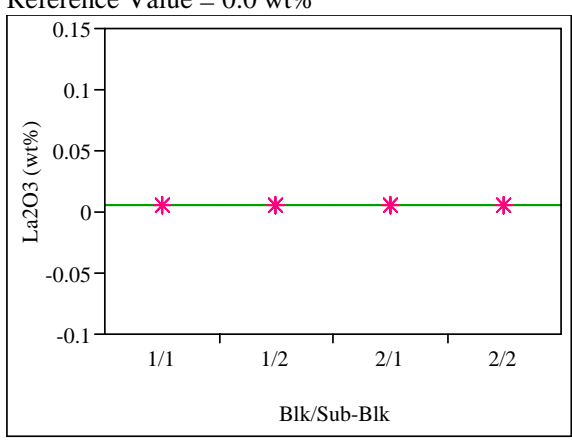

\section{Oneway Anova}

Summary of Fit

Rsquare

Adj Rsquare

Root Mean Square Error

Mean of Response

Observations (or Sum Wgts)

0.005864

Analysis of Variance

Source DF Sum of Squares Mean Square F Ratio Prob $>F$ Blk/Sub-Blk 3 Error

C. Total

$\begin{array}{lll}0 & 0 \\ 0 & 0\end{array}$

\section{Means for Oneway Anova}

Level Number Mean Std Error Lower 95\% Upper 95\% $\begin{array}{llllll}1 / 1 & 3 & 0.005864 & 0 & 0.00586 & 0.00586\end{array}$

$1 / 2 \quad 3 \quad 30.005864$

$2 / 1 \quad 30.005864$

$2 / 2 \quad 30.005864$

$\begin{array}{ll}0 & 0.00586 \\ 0 & 0.00586\end{array}$

$0 \quad 0.00586$

0.00586

0.00586

0.00586

Std Error uses a pooled estimate of error variance
Study Glass \#=200

Oneway Analysis of MgO (wt \%) By Blk/Sub-Blk

Reference Value $=1.21 \mathrm{wt} \%$

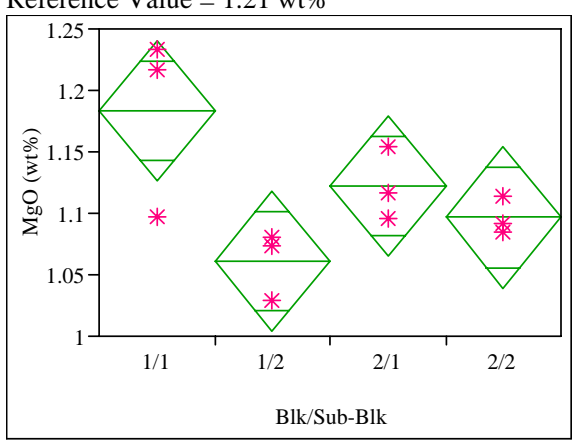

Oneway Anova

Summary of Fit

Rsquare

0.615574

Adj Rsquare

0.471414

Root Mean Square Error $\quad 0.042956$

Mean of Response

1.11576

Observations (or Sum Wgts)

12

Analysis of Variance

Source DF Sum of Squares Mean Square F Ratio Prob > F $\begin{array}{lrrrrr}\text { Blk/Sub-Blk } & 3 & 0.02363773 & 0.007879 & 4.2701 & 0.0447\end{array}$ $\begin{array}{lrr}\text { Error } & 8 & 0.01476178 \\ \text { C. Total } & 11 & 0.03839951\end{array}$

\section{Means for Oneway Anova}

Level Number Mean Std Error Lower 95\% Upper 95\% $\begin{array}{lllllr}1 / 1 & 3 & 1.18292 & 0.02480 & 1.1257 & 1.2401\end{array}$ $\begin{array}{llllll}1 / 2 & 3 & 1.06131 & 0.02480 & 1.0041 & 1.1185\end{array}$

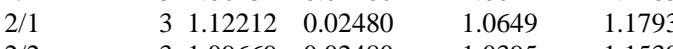
$\begin{array}{llllll}2 / 2 & 3 & 1.09669 & 0.02480 & 1.0395 & 1.1539\end{array}$

Std Error uses a pooled estimate of error variance 


\section{Exhibit B3. PSAL Measurements by Analytical Block for Samples of the}

Standard Glasses Prepared Using the LM Method (continued)

(Batch 1 - Glass \#100; U std - Glass \#200)

Study Glass \#=200

Oneway Analysis of $\mathrm{MnO}(\mathrm{wt} \%)$ By Blk/Sub-Blk Reference Value $=2.892 \mathrm{wt} \%$

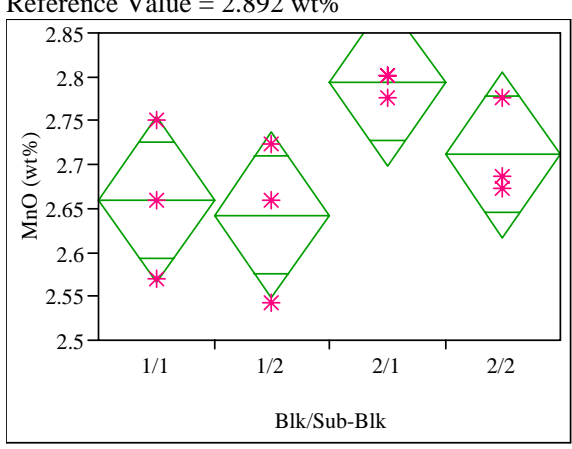

Oneway Anova

Summary of Fit

Rsquare

Adj Rsquare

Root Mean Square Error

Mean of Response

0.507798

0.323222

Observations (or Sum Wgts)

.701836

\section{Analysis of Variance}

Source DF Sum of Squares Mean Square F Ratio Prob $>$ F $\begin{array}{lrrrrr}\text { Blk/Sub-Blk } & 3 & 0.04116588 & 0.013722 & 2.7512 & 0.1122\end{array}$ $\begin{array}{lll}\text { Error } & 8 & 0.03990159\end{array}$

$\begin{array}{lrr}\text { Cror } & 8 & 0.03990159 \\ \text { Cotal } & 11 & 0.08106748\end{array}$

Means for Oneway Anova

Level Number Mean Std Error Lower 95\% Upper 95\% $\begin{array}{lllrrr}1 / 1 & 3 & 2.65987 & 0.04077 & 2.5658 & 2.7539\end{array}$ $\begin{array}{llllll}1 / 2 & 3 & 2.64266 & 0.04077 & 2.5486 & 2.7367\end{array}$ $\begin{array}{llllll}2 / 1 & 3 & 2.79330 & 0.04077 & 2.6993 & 2.8873\end{array}$ $\begin{array}{llllll}2 / 2 & 3 & 2.71152 & 0.04077 & 2.6175 & 2.8055\end{array}$

Std Error uses a pooled estimate of error variance

\section{Study Glass \#=200}

Oneway Analysis of Na2O (wt\%) By Blk/Sub-Blk Reference Value $=11.795 \mathrm{wt} \%$

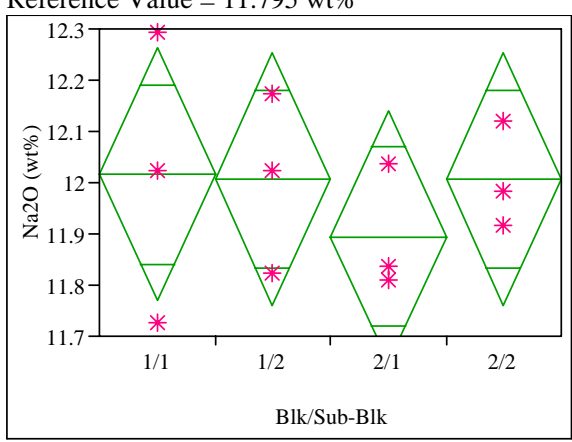

\section{Oneway Anova}

Summary of Fit

Adj Rsquare

0.098664

Root Mean Square Error $\quad 0.18536$

$-0.23934$

Mean of Response 11.98035

Observations (or Sum Wgts)

12

\section{Analysis of Variance}

Source DF Sum of Squares Mean Square F Ratio Prob > F $\begin{array}{llllll}\text { Blk/Sub-Blk } & 3 & 0.03008821 & 0.010029 & 0.2919 & 0.8303\end{array}$ Error 0.034358

\section{Means for Oneway Anova}

Level Number Mean Std Error Lower 95\% Upper 95\% $\begin{array}{llrrrr}1 / 1 & 3 & 12.0152 & 0.10702 & 11.768 & 12.262\end{array}$

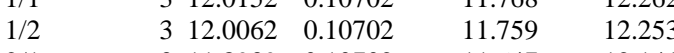
$\begin{array}{llllll}2 / 1 & 3 & 11.8939 & 0.10702 & 11.647 & 12.141\end{array}$ $\begin{array}{llllll}2 / 2 & 3 & 12.0062 & 0.10702 & 11.759 & 12.253\end{array}$

Std Error uses a pooled estimate of error variance
Study Glass \#=200

Oneway Analysis of NiO (wt\%) By Blk/Sub-Blk Reference Value $=1.12 \mathrm{wt} \%$

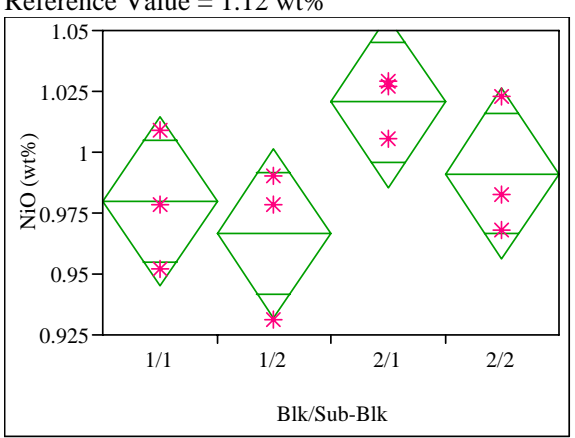

\section{Oneway Anova}

Summary of Fit

Rsquare

0.461514

Adj Rsquare

0.259582

Root Mean Square Error $\quad 0.026305$

Mean of Response 0.989581

Observations (or Sum Wgts)

$$
12
$$

Source DF Sum of Squares Mean Square F Ratio Prob > F $\begin{array}{llllll}\text { Blk/Sub-Blk } & 3 & 0.00474442 & 0.001581 & 2.2855 & 0.1557\end{array}$ $\begin{array}{lrrr}\text { Error } & 8 & 0.00553570 & 0.000692 \\ \text { C. Total } & 11 & 0.01028012 & \end{array}$

\section{Means for Oneway Anova}

Level Number Mean Std Error Lower 95\% Upper 95\% $\begin{array}{lrrrrr} & & & & \\ 1 / 1 & 3 & 0.97983 & 0.01519 & 0.94480 & 1.0148\end{array}$ $\begin{array}{llllll}1 / 1 & 3 & 0.97983 & 0.01519 & 0.94480 & 1.0148 \\ 1 / 2 & 3 & 0.96668 & 0.01519 & 0.93165 & 1.0017\end{array}$ $\begin{array}{llllll}2 / 1 & 3 & 1.02055 & 0.01519 & 0.98552 & 1.0556\end{array}$ $\begin{array}{llllll}2 / 2 & 3 & 0.99128 & 0.01519 & 0.95626 & 1.0263\end{array}$

Std Error uses a pooled estimate of error variance 


\section{Exhibit B3. PSAL Measurements by Analytical Block for Samples of the}

Standard Glasses Prepared Using the LM Method (continued)

(Batch 1 - Glass \#100; U std - Glass \#200)

Study Glass \#=200

Oneway Analysis of PbO (wt\%) By Blk/Sub-Blk Reference Value $=0.0 \mathrm{wt} \%$

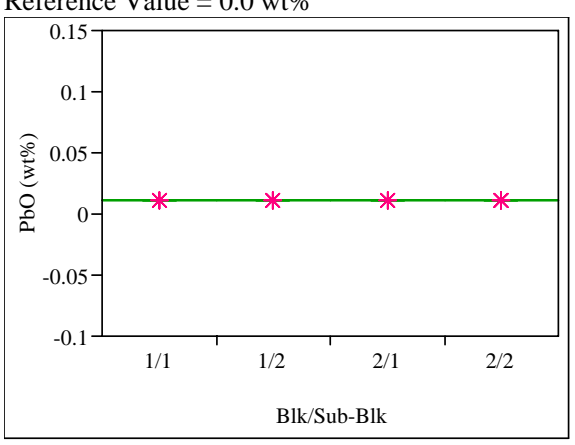

Oneway Anova
Summary of Fit

Rsquare

Adj Rsquare

Root Mean Square Error $\quad$ 2.12e-18

Mean of Response

0.010772

Observations (or Sum Wgts)

12

Analysis of Variance

Source DF Sum of Squares Mean Square F Ratio Prob $>F$ $\begin{array}{lrrrrr}\text { Blk/Sub-Blk } & 3 & 0 & 0 & 0.0000 & 1.0000\end{array}$ C. Total $11 \quad 3.6111 \mathrm{e}-35$

\section{Means for Oneway Anova}

Level Number Mean Std Error Lower 95\% Upper 95\% $\begin{array}{llllll}1 / 1 & 3 & 0.010772 & 1.227 \mathrm{e}-18 & 0.01077 & 0.01077\end{array}$ $\begin{array}{llllll}1 / 2 & 3 & 0.010772 & 1.227 \mathrm{e}-18 & 0.01077 & 0.01077\end{array}$

$\begin{array}{llllll}2 / 1 & 3 & 0.010772 & 1.227 \mathrm{e}-18 & 0.01077 & 0.01077 \\ 2 / 2 & 3 & 0.010772 & 1.227 \mathrm{e}-18 & 0.01077 & 0.01077\end{array}$

Std Error uses a pooled estimate of error variance

\section{Study Glass \#=200}

Oneway Analysis of SO4 (wt\%) By Blk/Sub-Blk Reference Value $=0.0 \mathrm{wt} \%$

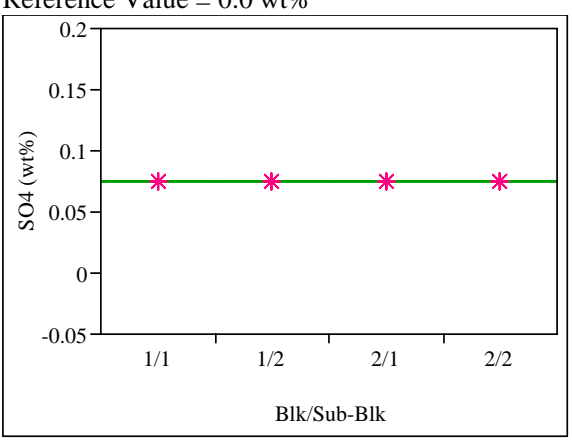

\section{Oneway Anova}

Summary of Fit

Rsquare

Adj Rsquare

Root Mean Square Error

Mean of Response

Observations (or Sum Wgts)

0
0.074898

Analysis of Variance

Source DF Sum of Squares Mean Square F Ratio Prob $>$ F Blk/Sub-Blk 3 Error

C. Tot

$$
\begin{array}{r}
3 \\
8 \\
11
\end{array}
$$

Means for Oneway Anova

Level Number Mean Std Error Lower 95\% Upper 95\% $\begin{array}{lllllll}1 / 1 & 3 & 0.074898 & 0 & 0.07490 & 0.07490\end{array}$ $\begin{array}{lll}1 / 2 & 3 & 0.074898\end{array}$

$\begin{array}{llll}2 / 1 & 3 & 0.074898\end{array}$

30.074898

0.07490
0.07490

$0 \quad 0.07490$

0.07490

0.07490
0.07490

0.07490

Std Error uses a pooled estimate of error variance
Study Glass \#=200

Oneway Analysis of ThO2 (wt\%) By Blk/Sub-Blk Reference Value $=0.0 \mathrm{wt} \%$

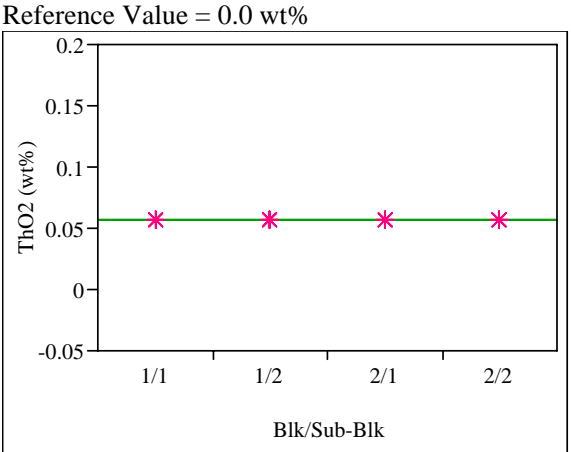

\section{Oneway Anova}

Summary of Fit

Rsquare

Adj Rsquare

Root Mean Square Error

Mean of Response

Analysis of Variance

Source DF Sum of Squares Mean Square F Ratio Prob > F Blk/Sub-Blk 3

$\begin{array}{lr}\text { Error } & 8 \\ \text { C. } & 11\end{array}$

\section{Means for Oneway Anova}

Level Number Mean Std Error Lower 95\% Upper 95\%

$\begin{array}{llllll}1 / 1 & 3 & 0.056895 & 0 & 0.05690 & 0.05690\end{array}$

$\begin{array}{llllll}1 / 2 & 3 & 0.056895 & 0 & 0.05690 & 0.05690\end{array}$

$\begin{array}{llllll}2 / 1 & 3 & 0.056895 & 0 & 0.05690 & 0.05690 \\ 2 / 2 & 3 & 0.056895 & 0 & 0.05690 & 0.05690\end{array}$

Std Error uses a pooled estimate of error variance 


\section{Exhibit B3. PSAL Measurements by Analytical Block for Samples of the}

Standard Glasses Prepared Using the LM Method (continued)

(Batch 1 - Glass \#100; U std - Glass \#200)

Study Glass \#=200

Oneway Analysis of TiO2 (wt\%) By Blk/Sub-Blk Reference Value $=1.049 \mathrm{wt} \%$

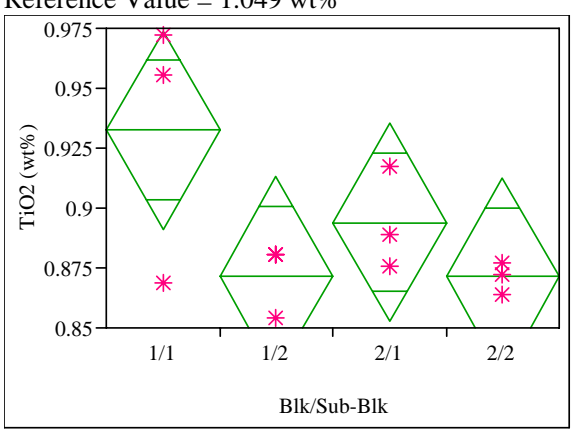

\section{Oneway Anova}

Summary of Fit

Rsquare

Adj Rsquare

0.49292

Root Mean Square Erro

0.302764

Mean of Response

0.030899

Observations (or Sum Wgts)

12

Analysis of Variance

Source DF Sum of Squares Mean Square F Ratio Prob > F $\begin{array}{llllll}\text { Blk/Sub-Blk } & 3 & 0.00742483 & 0.002475 & 2.5922 & 0.1251\end{array}$

$\begin{array}{lll}\text { Error } & 8 & 0.00763813\end{array}$ 0.000955

$\begin{array}{lll}\text { C. Total } & 11 & 0.01506296\end{array}$

Means for Oneway Anova

Level Number Mean Std Error Lower 95\% Upper 95\%

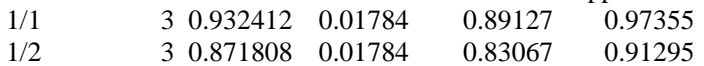

$\begin{array}{llllll}2 / 1 & 3 & 0.894048 & 0.01784 & 0.85291 & 0.93519\end{array}$

$\begin{array}{llllll}2 / 2 & 3 & 0.871252 & 0.01784 & 0.83011 & 0.91239\end{array}$

Std Error uses a pooled estimate of error variance

\section{Study Glass \#=200}

Oneway Analysis of $\mathrm{ZnO}$ (wt\%) By Blk/Sub-Blk

Reference Value $=0.0 \mathrm{wt} \%$

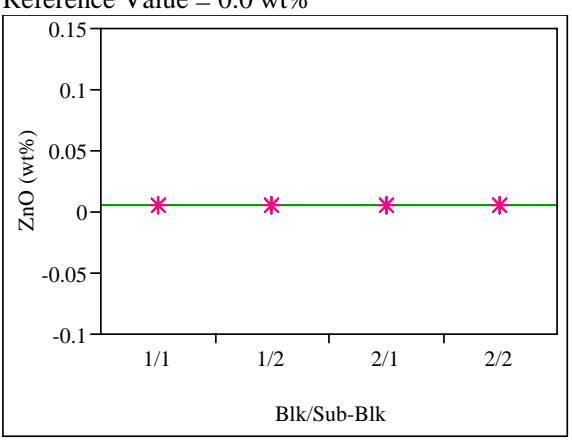

\section{Oneway Anova}

Summary of Fit

Rsquare

Adj Rsquare

Root Mean Square Error

Mean of Response

Observations (or Sum Wgts)

0.006224

Analysis of Variance

Source DF Sum of Squares Mean Square F Ratio Prob $>F$ Blk/Sub-Blk 3

Error

C. Total 11

\section{Means for Oneway Anova}

Level Number Mean Std Error Lower 95\% Upper 95\%

$\begin{array}{llllll}1 / 1 & 3 & 0.006224 & 0 & 0.00622 & 0.00622\end{array}$

$1 / 2 \quad 3 \quad 30.006224$

$2 / 1 \quad 30.006224$

$2 / 2 \quad 30.006224$

Std Error uses a pooled estimate of error variance
Study Glass \#=200

Oneway Analysis of ZrO2 (wt\%) By Blk/Sub-Blk

Reference Value $=0.0 \mathrm{wt} \%$

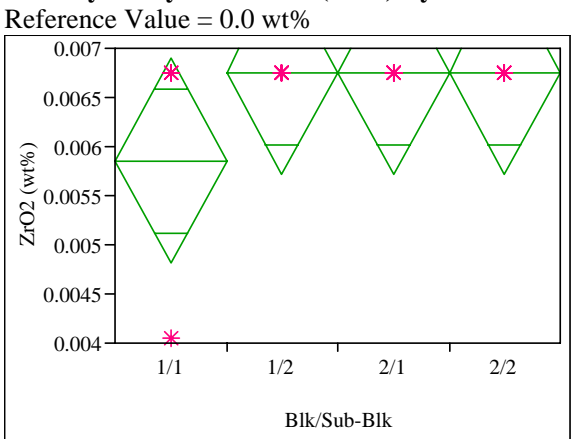

\section{Oneway Anova}

Summary of Fit

Rsquare

0.272727

Adj Rsquare

Root Mean Square Error

0.00078

Mean of Response

0.006529

Observations (or Sum Wgts)

Analysis of Variance

Source DF Sum of Squares Mean Square F Ratio Prob > F $\begin{array}{llllll}\text { Blk/Sub-Blk } & 3 & 1.82466 e-6 & 6.0822 \mathrm{e}-7 & 1.0000 & 0.4411\end{array}$ $\begin{array}{lrrr}\text { Error } & 8 & 4.86576 \mathrm{e}-6 & 6.0822 \mathrm{e}-7 \\ \text { C. Total } & 11 & 6.69042 \mathrm{e}-6 & \end{array}$

Means for Oneway Anova

Level Number Mean Std Error Lower 95\% Upper 95\% $\begin{array}{llllll}1 / 1 & 3 & 0.005853 & 0.00045 & 0.00482 & 0.00689\end{array}$ $\begin{array}{llllll}1 / 2 & 3 & 0.006754 & 0.00045 & 0.00572 & 0.00779\end{array}$ $\begin{array}{llllll}2 / 1 & 3 & 0.006754 & 0.00045 & 0.00572 & 0.00779\end{array}$ $\begin{array}{llllll}2 / 2 & 3 & 0.006754 & 0.00045 & 0.00572 & 0.00779\end{array}$

Std Error uses a pooled estimate of error variance 


\section{Exhibit B4: PSAL Measurements by Analytical Block for Samples of the} Standard Glasses Prepared Using the PF Method

\section{(Batch 1 - Glass \#100; U std - Glass \#200)}

\section{Study Glass \#=100}

Oneway Analysis of B2O3 (wt\%) By Blk/Sub-Blk Reference Value $=7.777 \mathrm{wt} \%$

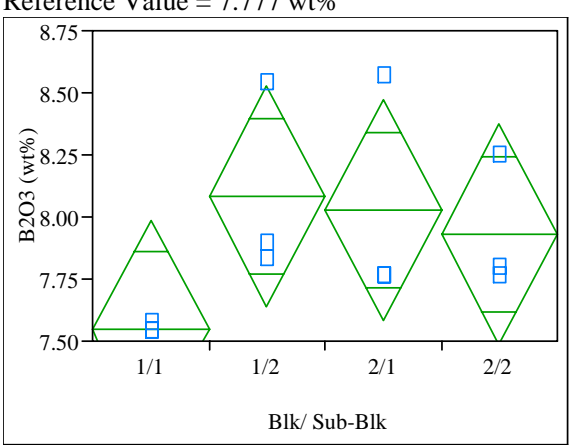

\section{Oneway Anova}

Summary of Fit

$\begin{array}{lr}\text { Rsquare } & 0.374015 \\ \text { Adj Rsquare } & 0.139271 \\ \text { Root Mean Square Error } & 0.33268 \\ \text { Mean of Response } & 7.896805 \\ \text { Observations (or Sum Wgts) } & 12\end{array}$

Analysis of Variance

Source DF Sum of Squares Mean Square F Ratio Prob > F $\begin{array}{llllll}\text { Blk/ Sub-Blk } & 3 & 0.5290148 & 0.176338 & 1.5933 & 0.2657\end{array}$ $\begin{array}{lrrr}\text { Error } & 8 & 0.8854064 & 0.110676 \\ \text { C. Total } & 11 & 1.4144211 & \end{array}$ 1.4144211

\section{Means for Oneway Anova}

Level Number Mean Std Error Lower 95\% Upper 95\% $\begin{array}{llllll}1 / 1 & 3 & 7.54530 & 0.19207 & 7.1024 & 7.9882 \\ 1 / 2 & 3 & 8.08195 & 0.19207 & 7.6390 & 8.5249\end{array}$

$\begin{array}{llllll}1 / 2 & 3 & 8.08195 & 0.19207 & 7.6390 & 8.5249\end{array}$

$\begin{array}{llllll}2 / 1 & 3 & 8.02828 & 0.19207 & 7.5854 & 8.4712\end{array}$

Std Error uses a pooled estimate of error variance

\section{Study Glass \#=100}

Oneway Analysis of Fe2O3 (wt\%) By Blk/Sub-Blk

Reference Value $=12.839 \mathrm{wt} \%$

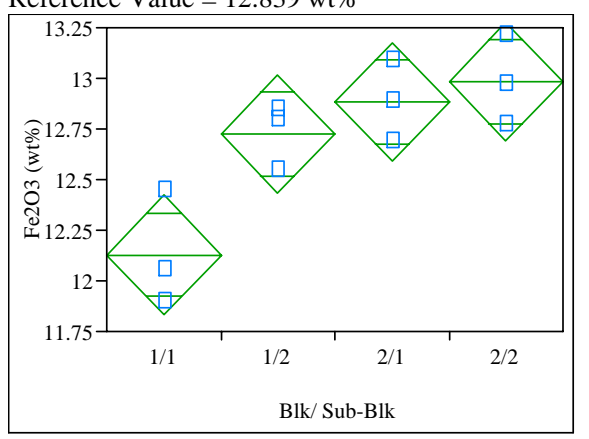

Oneway Anova

Summary of Fit

\section{Adj Rsquare $\quad 0.686536$ \\ Root Mean Square Error $\quad 0.220138$ \\ Mean of Response 12.67906 \\ Observations (or Sum Wgts)}

Source DF Sum of Squares Mean Square F Ratio Prob $>F$ $\begin{array}{lrrrrr}\text { Blk/ Sub-Blk } & 3 & 1.3128882 & 0.437629 & 9.0306 & 0.0060 \\ \text { Error } & 8 & 0.3876866 & 0.048461 & & \end{array}$ Error 1.7005749 0.04846

Means for Oneway Anova

Level Number Mean Std Error Lower 95\% Upper 95\% $\begin{array}{llllrr}1 / 1 & 3 & 12.1286 & 0.12710 & 11.836 & 12.422\end{array}$ $\begin{array}{llllll}1 / 1 & 3 & 12.7243 & 0.12710 & 12.431 & 13.017 \\ 2 / 1 & 3 & 12.8816 & 0.12710 & 12.589 & 13.175\end{array}$ $\begin{array}{llllll}1 / 2 & 3 & 12.8816 & 0.12710 & 12.589 & 13.175 \\ 2 / 2 & 3 & 12.9817 & 0.12710 & 12.689 & 13.275\end{array}$

Std Error uses a pooled estimate of error variance

Study Glass \#=100

Oneway Analysis of Li2O (wt\%) By Blk/Sub-Blk Reference Value $=4.429 \mathrm{wt} \%$

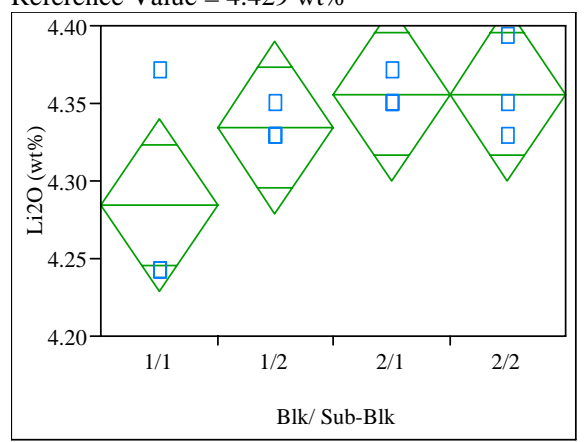

\section{Oneway Anova}

Summary of Fit

$\begin{array}{lr}\text { Rsquare } & 0.425837 \\ \text { Adj Rsquare } & 0.210526 \\ \text { Root Mean Square Error } & 0.041691 \\ \text { Mean of Response } & 4.332711 \\ \text { Observations (or Sum Wgts) } & 12\end{array}$

Observations (or Sum Wgts)

Analysis of Variance

Source DF Sum of Squares Mean Square F Ratio Prob $>$ F $\begin{array}{llllll}\text { Blk/ Sub-Blk } & 3 & 0.01031283 & 0.003438 & 1.9778 & 0.1960\end{array}$ $\begin{array}{lrr}\text { Error } & 8 & 0.01390494 \\ \text { C. Total } & 11 & 0.02421776\end{array}$

\section{Means for Oneway Anova}

Level Number Mean Std Error Lower 95\% Upper 95\% $\begin{array}{llllll}1 / 1 & 3 & 4.28427 & 0.02407 & 4.2288 & 4.3398\end{array}$ $\begin{array}{llllll}1 / 2 & 3 & 4.33451 & 0.02407 & 4.2790 & 4.3900\end{array}$ $\begin{array}{llllll}2 / 1 & 3 & 4.35603 & 0.02407 & 4.3005 & 4.4115\end{array}$

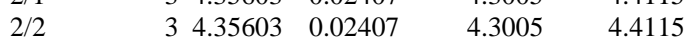

Std Error uses a pooled estimate of error variance 


\section{Exhibit B4: PSAL Measurements by Analytical Block for Samples of the}

Standard Glasses Prepared Using the PF Method (continued)

(Batch 1 - Glass \#100; U std - Glass \#200)

Study Glass \#=100

Oneway Analysis of $\mathrm{SiO} 2$ (wt\%) By Blk/Sub-Blk

Reference Value $=50.22 \mathrm{wt} \%$

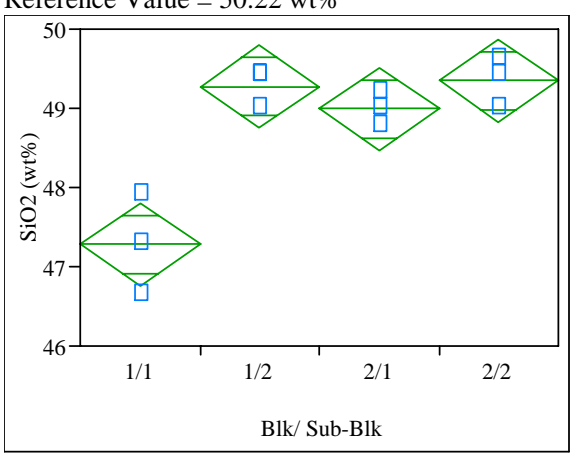

Oneway Anova

Summary of Fit

$\begin{array}{lr}\text { Rsquare } & 0.872423 \\ \text { Adj Rsquare } & 0.824582 \\ \text { Root Mean Square Error } & 0.395433 \\ \text { Mean of Response } & 48.72256 \\ \text { Observations (or Sum Wgts) } & 12\end{array}$

Analysis of Variance

Source DF Sum of Squares Mean Square F Ratio Prob > F $\begin{array}{lrrrrr}\text { Blk/ Sub-Blk } & 3 & 8.5544366 & 2.85148 & 18.2358 & 0.0006\end{array}$ $\begin{array}{lrrr}\text { Error } & 8 & 1.2509386 & 0.15637 \\ \text { C. Total } & 11 & 9.8053751 & \end{array}$

\section{Means for Oneway Anova}

Level Number Mean Std Error Lower 95\% Upper 95\% $\begin{array}{llrrrr}1 / 1 & 3 & 47.2785 & 0.22830 & 46.752 & 47.805\end{array}$ $\begin{array}{llllll}1 / 1 & 3 & 47.2785 & 0.22830 & 46.752 & 47.805 \\ 1 / 2 & 3 & 49.2752 & 0.22830 & 48.749 & 49.802\end{array}$ $\begin{array}{llllll}2 / 1 & 3 & 48.9900 & 0.22830 & 48.464 & 49.516\end{array}$ $\begin{array}{llllll}2 / 2 & 3 & 49.3465 & 0.22830 & 48.820 & 49.873\end{array}$

Std Error uses a pooled estimate of error variance

\section{Study Glass \#=100}

Oneway Analysis of U3O8 (wt\%) By Blk/Sub-Blk

Reference Value $=0.0 \mathrm{wt} \%$

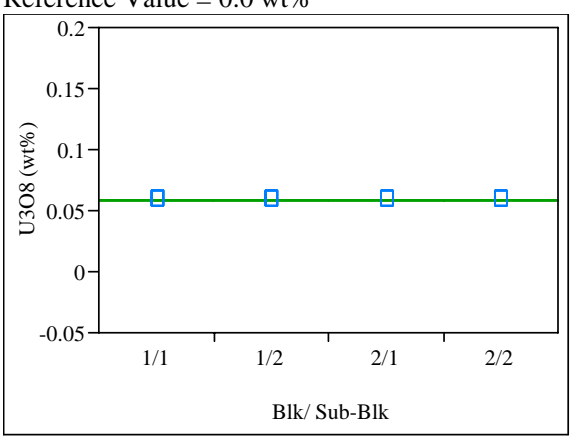

Oneway Anova

Summary of Fit

Rsquare

Adj Rsquare

Root Mean Square Error

Mean of Response

0
0.05896

Observations (or Sum Wgts)

Analysis of Variance
Source DF Sum of Squares Mean Square F Ratio Prob > F

Source DF

$\begin{array}{lr}\text { Blk/ Sub-Blk } & 3 \\ \text { Error } & 8 \\ \text { C. } & 11\end{array}$

$\begin{array}{lll}8 & 0 & 0 \\ 1 & 0 & 0\end{array}$

Means for Oneway Anova

Level Number Mean Std Error Lower 95\% Upper 95\%

$\begin{array}{lllrrr}1 / 1 & 3 & 0.058960 & 0 & 0.05896 & 0.05896\end{array}$

$\begin{array}{llllll}1 / 2 & 3 & 0.058960 & 0 & 0.05896 & 0.05896\end{array}$

$\begin{array}{llllll}2 / 1 & 3 & 0.058960 & 0 & 0.05896 & 0.05896\end{array}$

$2 / 2 \quad 3 \quad 0.058960$

Std Error uses a pooled estimate of error variance

Study Glass \#=100

Oneway Analysis of B2O3 (wt\%) By Blk/Sub-Blk Reference Value $=9.209 \mathrm{wt} \%$

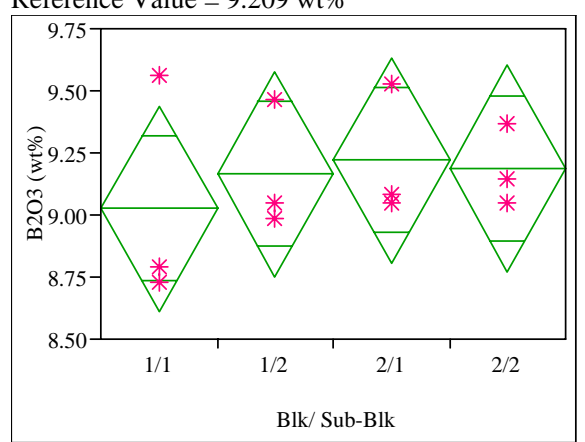

\section{Oneway Anova}

Summary of Fit

\begin{tabular}{lr} 
Rsquare & 0.078002 \\
Adj Rsquare & -0.26775 \\
Root Mean Square Error & 0.310655 \\
Mean of Response & 9.149883 \\
\hline Observations (or Sum Wgts) &
\end{tabular}

Observations (or Sum Wgts)

Analysis of Variance

Source DF Sum of Squares Mean Square F Ratio Prob $>F$ $\begin{array}{llllll}\text { Blk/ Sub-Blk } & 3 & 0.06531686 & 0.021772 & 0.2256 & 0.8760\end{array}$ $\begin{array}{lrr}\text { Error } & 8 & 0.77205223 \\ \text { C. Total } & 11 & 0.83736909\end{array}$

\section{Means for Oneway Anova}

Level Number Mean Std Error Lower 95\% Upper 95\% $\begin{array}{llllll}1 / 1 & 3 & 9.02645 & 0.17936 & 8.6129 & 9.4401\end{array}$ $\begin{array}{llllll}1 / 2 & 3 & 9.16598 & 0.17936 & 8.7524 & 9.5796\end{array}$ $\begin{array}{llllll}2 / 1 & 3 & 9.21965 & 0.17936 & 8.8060 & 9.6332\end{array}$

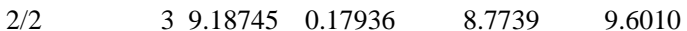

Std Error uses a pooled estimate of error variance 


\section{Exhibit B4: PSAL Measurements by Analytical Block for Samples of the}

Standard Glasses Prepared Using the PF Method (continued)

(Batch 1 - Glass \#100; U std - Glass \#200)
Study Glass \#=200

Oneway Analysis of Fe2O3 (wt\%) By Blk/Sub-Blk Reference Value $=13.196 \mathrm{wt} \%$

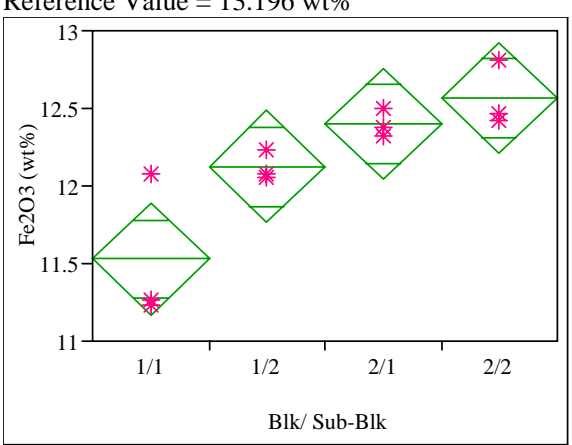

\section{Oneway Anova}

Summary of Fit

$\begin{array}{lr}\text { Rsquare } & 0.762287 \\ \text { Adj Rsquare } & 0.673144 \\ \text { Root Mean Square Error } & 0.270102 \\ \text { Mean of Response } & 12.15483 \\ \text { Observations (or Sum Wgts) } & \end{array}$

(2.15483

Analysis of Variance

Source DF Sum of Squares Mean Square F Ratio Prob > F $\begin{array}{llllll}\text { Blk/Sub-Blk } & 3 & 1.8715931 & 0.623864 & 8.5513 & 0.0071\end{array}$ $\begin{array}{lrrr}\text { Error } & 8 & 0.5836422 & 0.072955 \\ \text { C. Total } & 11 & 2.4552352 & \end{array}$

Level Number Mean Std Error Lower 95\% Upper 95\% $\begin{array}{llllll}1 / 1 & 3 & 11.5281 & 0.15594 & 11.169 & 11.888 \\ 1 / 2 & 3 & 12.1239 & 0.15594 & 11.764 & 12.483\end{array}$

$\begin{array}{llllll}1 / 2 & 3 & 12.1239 & 0.15594 & 11.764 & 12.483\end{array}$

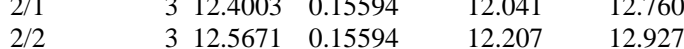

Std Error uses a pooled estimate of error variance

\section{Means for Oneway Anova}

\section{Study Glass \#=200}

Oneway Analysis of Li2O (wt\%) By Blk/Sub-Blk

Reference Value $=3.057 \mathrm{wt} \%$

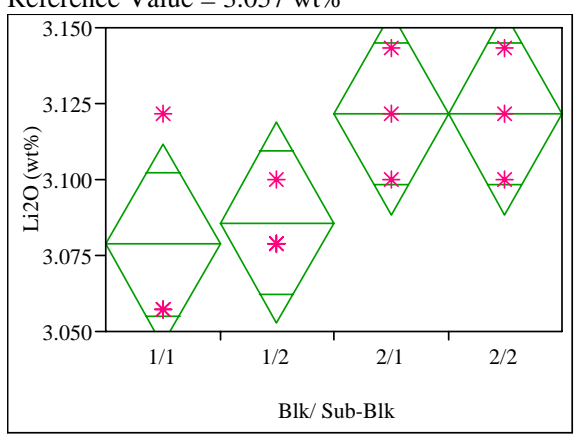

Oneway Anova

Summary of Fit

\section{Adj Rsquare $\quad 0.298805$ \\ Root Mean Square Error $\quad 0.02486$ \\ Mean of Response \\ 0.02486
3.10197 \\ Observations (or Sum Wgts)}

Source DF Sum of Squares Mean Square F Ratio Prob > F $\begin{array}{lrrrrr}\text { Blk/ Sub-Blk } & 3 & 0.00475085 & 0.001584 & 2.5625 & 0.1278 \\ \text { Error } & 8 & 0.00494398 & 0.000618 & & \end{array}$ 0.000618

C. Tota

Means for Oneway Anova

Level Number Mean Std Error Lower 95\% Upper 95\%

$\begin{array}{lllllr}1 / 1 & 3 & 3.07865 & 0.01435 & 3.0455 & 3.1117 \\ 1 / 2 & 3 & 3.08582 & 0.01435 & 3.0527 & 3.1189 \\ 2 / 1 & 3 & 3.12171 & 0.01435 & 3.0886 & 3.1548 \\ 2 / 2 & 3 & 3.12171 & 0.01435 & 3.0886 & 3.1548\end{array}$

$\begin{array}{lll}3 & 3.12171 & 0.01435\end{array}$

.1548

Std Error uses a pooled estimate of error variance
Study Glass \#=200

Oneway Analysis of SiO2 (wt\%) By Blk/Sub-Blk Reference Value $=45.353 \mathrm{wt} \%$

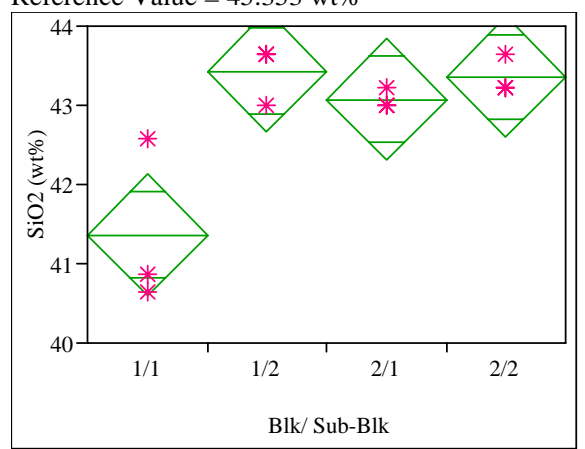

Oneway Anova

Summary of Fit

$\begin{array}{lr}\text { Rsquare } & 0.763185 \\ \text { Adj Rsquare } & 0.674379 \\ \text { Root Mean Square Error } & 0.576024 \\ \text { Mean of Response } & 42.80383 \\ \text { Observations (or Sum Wgts) } & 12\end{array}$

Analysis of Variance

Source DF Sum of Squares Mean Square F Ratio Prob > F $\begin{array}{llllll}\text { Blk/ Sub-Blk } & 3 & 8.554437 & 2.85148 & 8.5939 & 0.0070\end{array}$

$\begin{array}{lrrr}\text { Error } & 8 & 2.654431 & 0.33180\end{array}$

$\begin{array}{lll}\text { C. Total } & 11 & 11.208867\end{array}$

Means for Oneway Anova

Level Number Mean Std Error Lower 95\% Upper 95\%

$\begin{array}{llllll}1 / 1 & 3 & 41.3598 & 0.33257 & 40.593 & 42.127\end{array}$

$\begin{array}{llllll}1 / 2 & 3 & 43.4278 & 0.33257 & 42.661 & 44.195\end{array}$

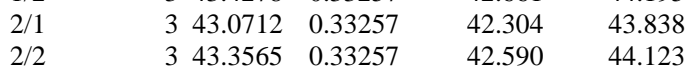

Std Error uses a pooled estimate of error variance 


\section{Exhibit B4: PSAL Measurements by Analytical Block for Samples of the} Standard Glasses Prepared Using the PF Method (continued)

(Batch 1 - Glass \#100; U std - Glass \#200)

Study Glass \#=200

Oneway Analysis of U3O8 (wt\%) By Blk/Sub-Blk

Oneway Analysis of $\mathbf{U} 308(\mathrm{wt} \%$
Reference Value $=2.406 \mathrm{wt} \%$

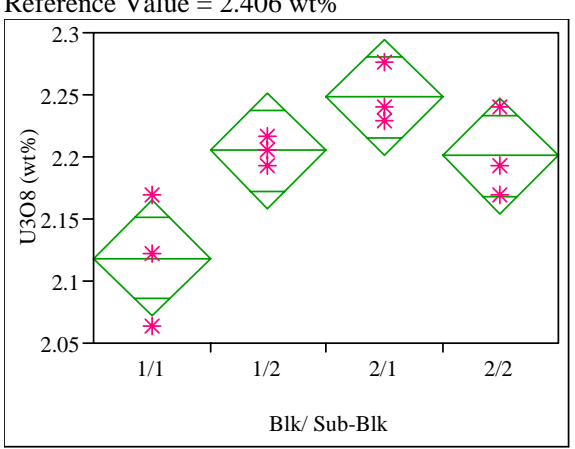

Oneway Anova

Summary of Fit

$\begin{array}{lr}\text { Rsquare } & 0.730769 \\ \text { Adj Rsquare } & 0.629808 \\ \text { Root Mean Square Error } & 0.034881 \\ \text { Mean of Response } & 2.193312 \\ \text { Observations (or Sum Wgts) } & \end{array}$

Observations (or Sum Wgts)

Analysis of Variance

Source DF Sum of Squares Mean Square F Ratio Prob > F

$\begin{array}{lrllll}\text { Blk/ Sub-Blk } & 3 & 0.02641974 & 0.008807 & 7.2381 & 0.0114\end{array}$

$\begin{array}{lrrr}\text { Error } & 8 & 0.00973359 & 0.00121\end{array}$

\section{Means for Oneway Anova}

Level Number Mean Std Error Lower 95\% Upper 95\%

$\begin{array}{llllll}1 / 1 & 3 & 2.11863 & 0.02014 & 2.0722 & 2.1651 \\ 1 / 2 & 3 & 2.20510 & 0.02014 & 2.1587 & 2.2515\end{array}$

$\begin{array}{llllll}1 / 1 & 3 & 2.20510 & 0.02014 & 2.1587 & 2.2515\end{array}$

$\begin{array}{llllll}2 / 1 & 3 & 2.24834 & 0.02014 & 2.2019 & 2.2948 \\ 2 / 2 & 3 & 2.20117 & 0.02014 & 2.1547 & 2.2476\end{array}$

Std Error uses a pooled estimate of error variance 
Exhibit B5. Measured and Measured Bias-Corrected Oxide Weight Percents by Glass ID for the Glasses Prepared Using the LM Method

(100 - Batch 1; 200 - Ustd)

Variability Chart for Al2O3 (wt \%)

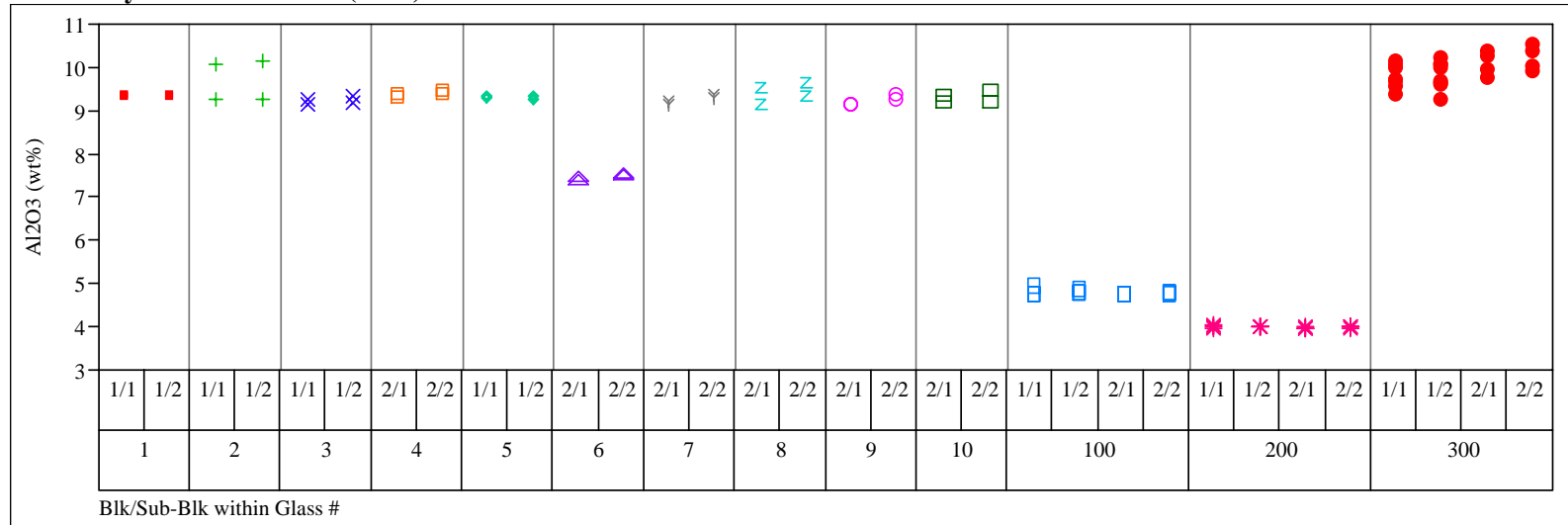

Variability Chart for $\mathrm{BaO}$ (wt\%)

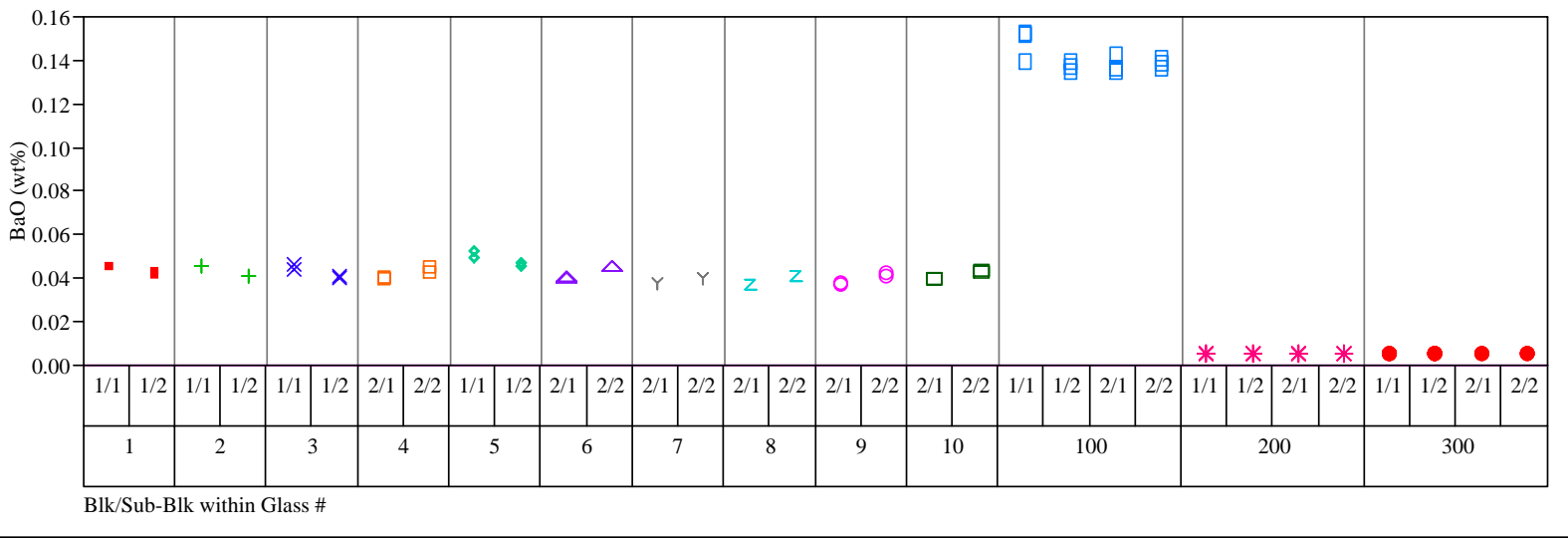

Variability Chart for $\mathrm{CaO}$ (wt\%)

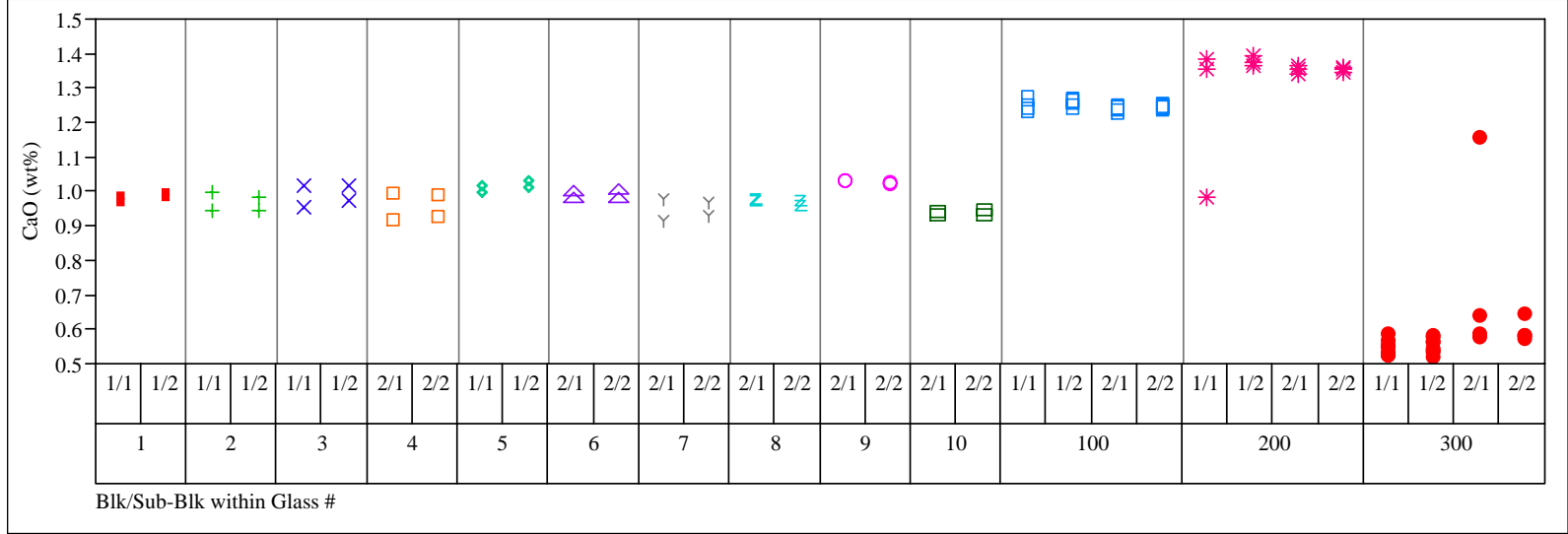


Exhibit B5. Measured and Measured Bias-Corrected Oxide Weight Percents by Glass ID for the Glasses Prepared Using the LM Method (continued) (100 - Batch 1; 200 - Ustd)

Variability Chart for Ce2O3 (wt\%)

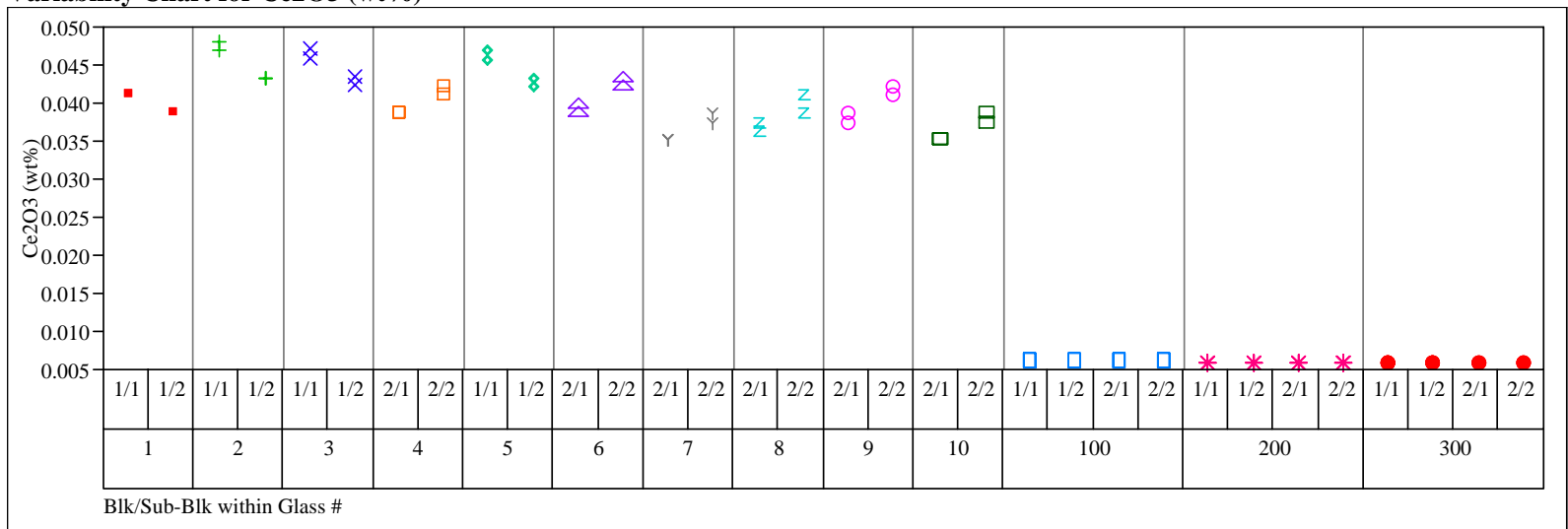

Variability Chart for Cr2O3 (wt\%)

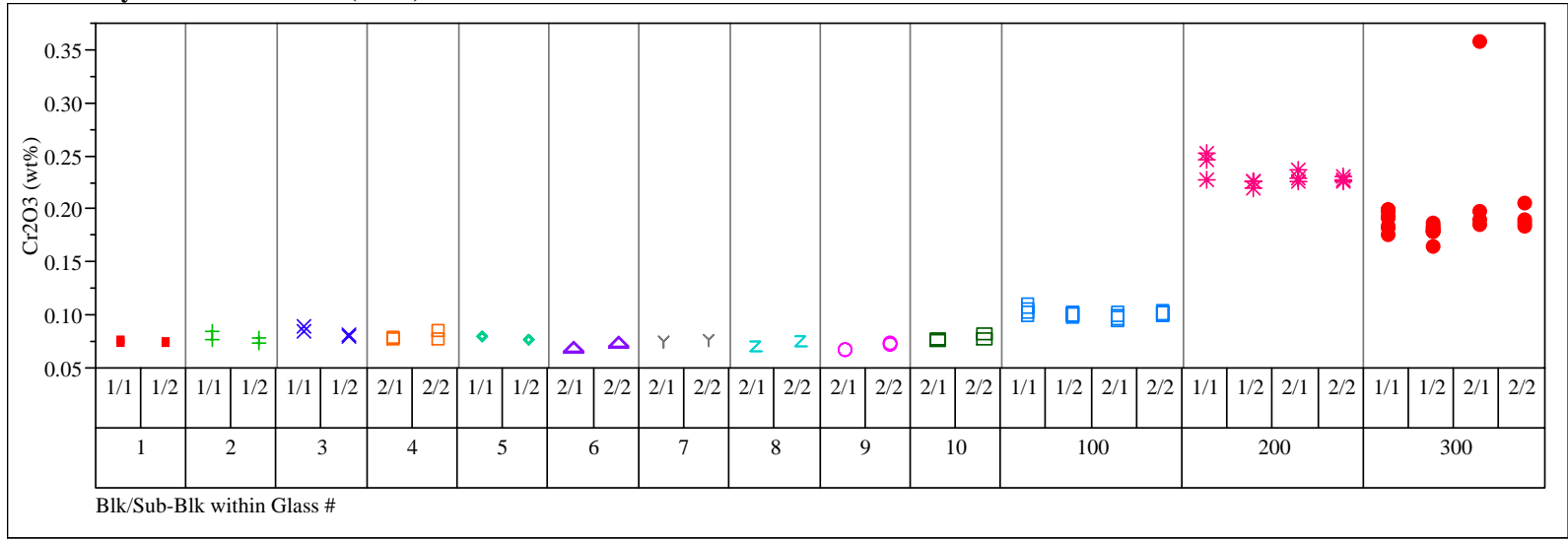

Variability Chart for $\mathrm{CuO}(\mathrm{wt} \%)$

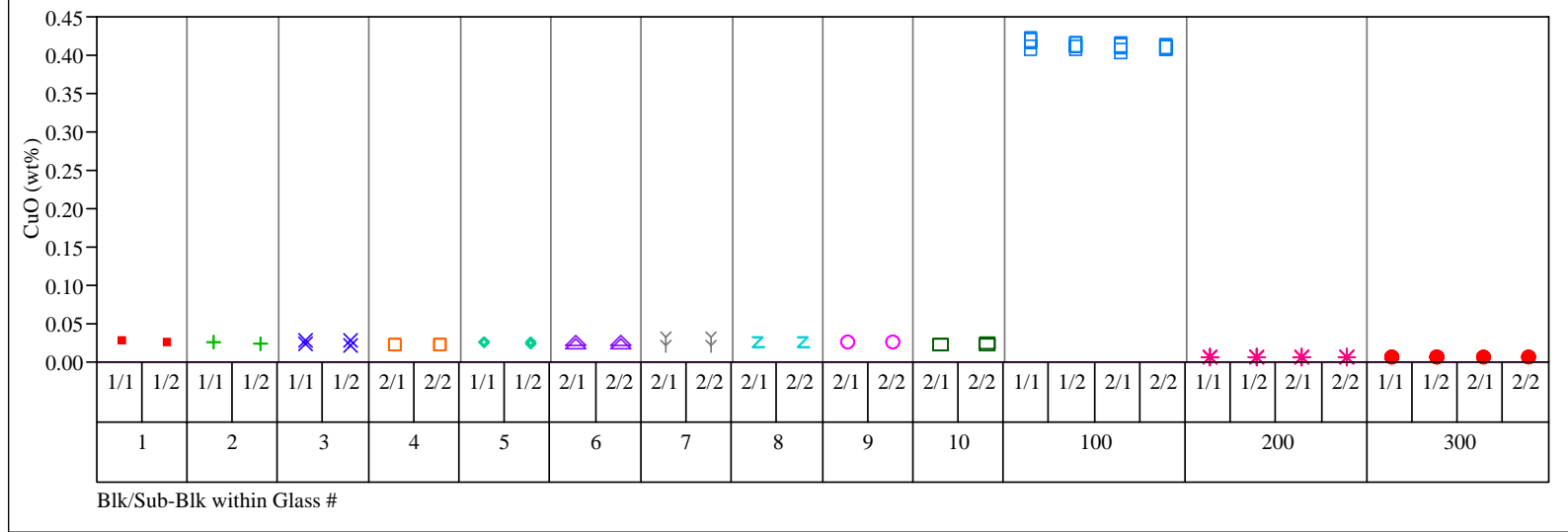


Exhibit B5. Measured and Measured Bias-Corrected Oxide Weight Percents by Glass ID for the Glasses Prepared Using the LM Method (continued) (100 - Batch 1; 200 - Ustd)

Variability Chart for K2O (wt\%)

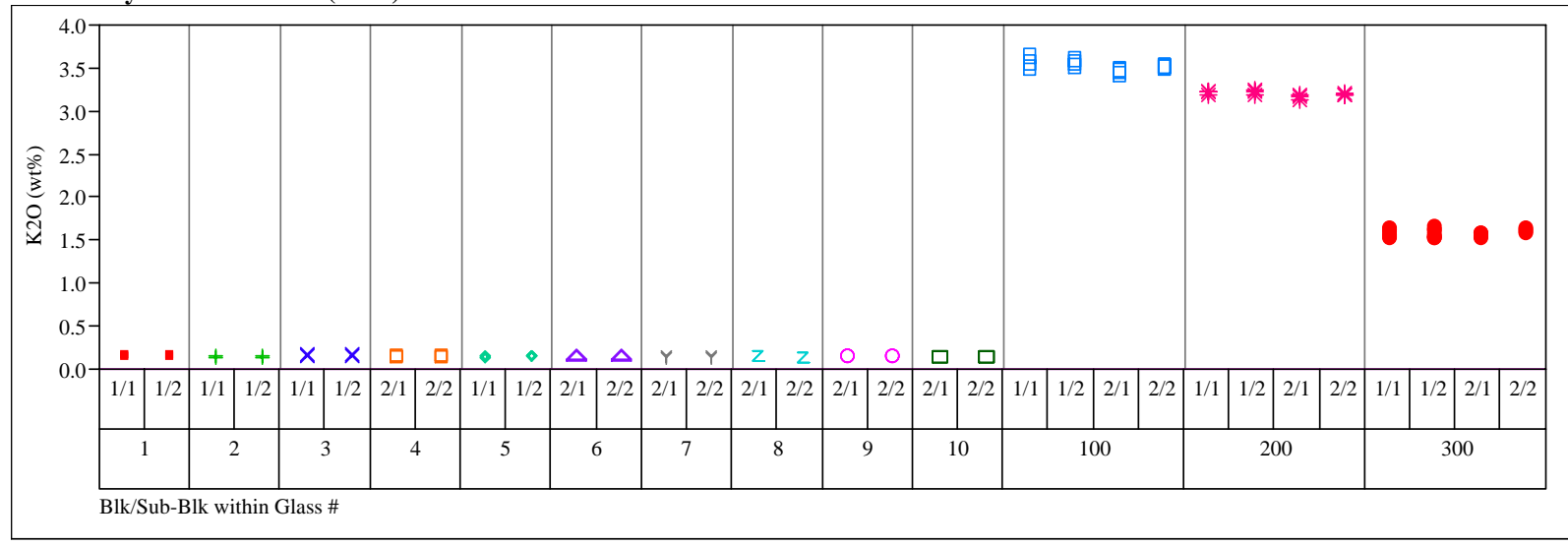

Variability Chart for La2O3 (wt\%)

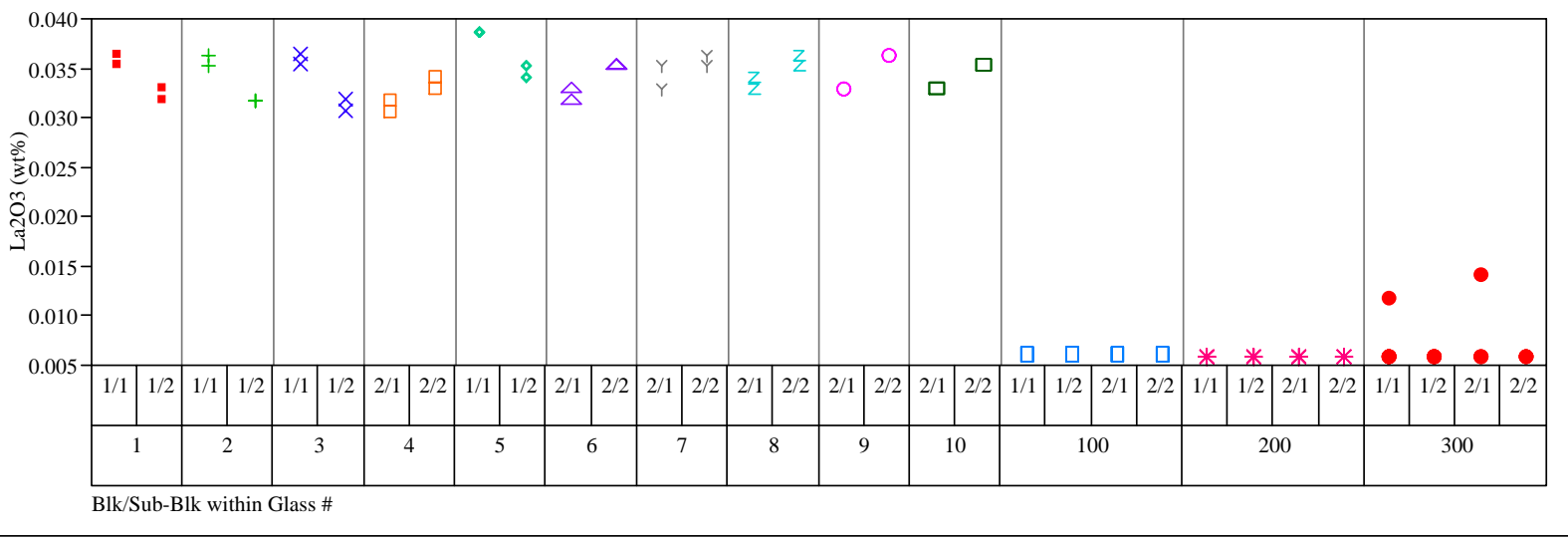

Variability Chart for MgO (wt\%)

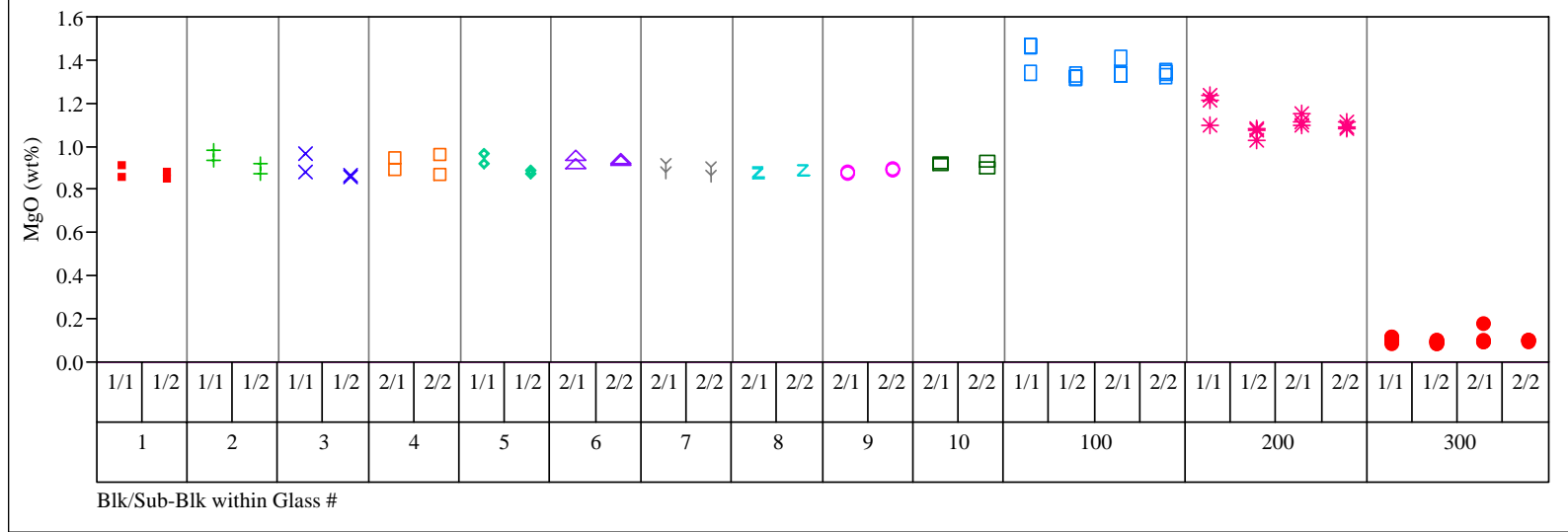


Exhibit B5. Measured and Measured Bias-Corrected Oxide Weight Percents by Glass ID for the Glasses Prepared Using the LM Method (continued) (100 - Batch 1; 200 - Ustd)

Variability Chart for $\mathrm{MnO}$ (wt\%)

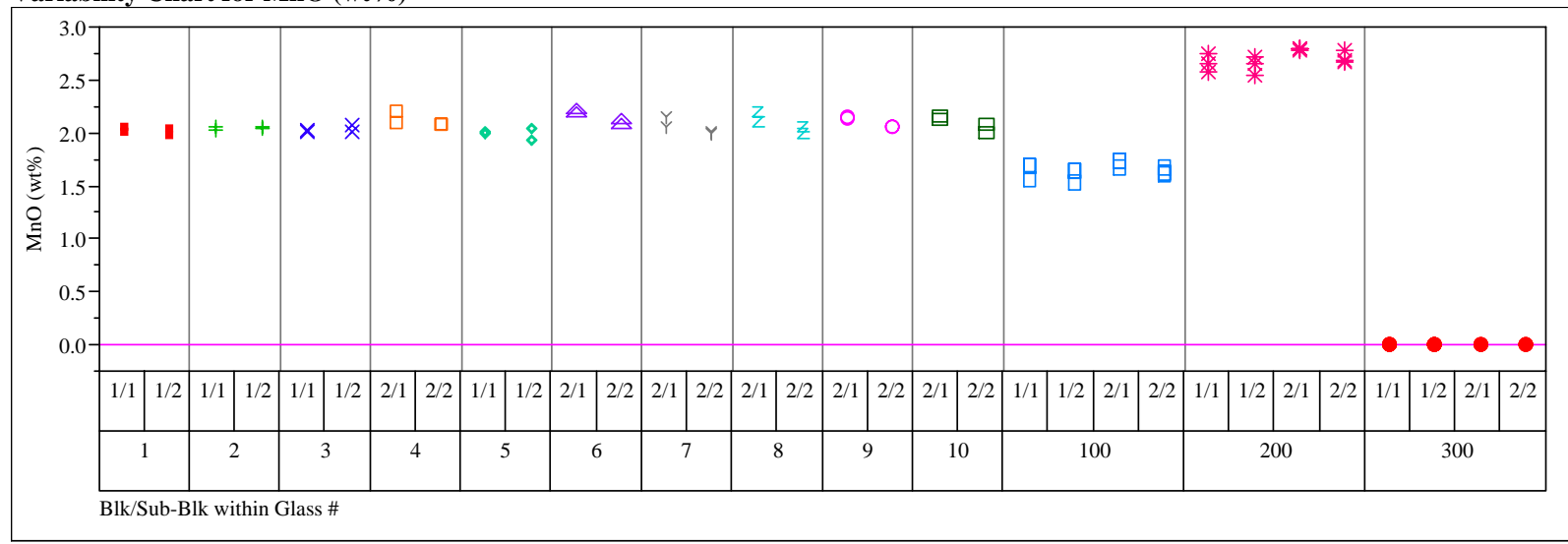

Variability Chart for Na2O (wt\%)

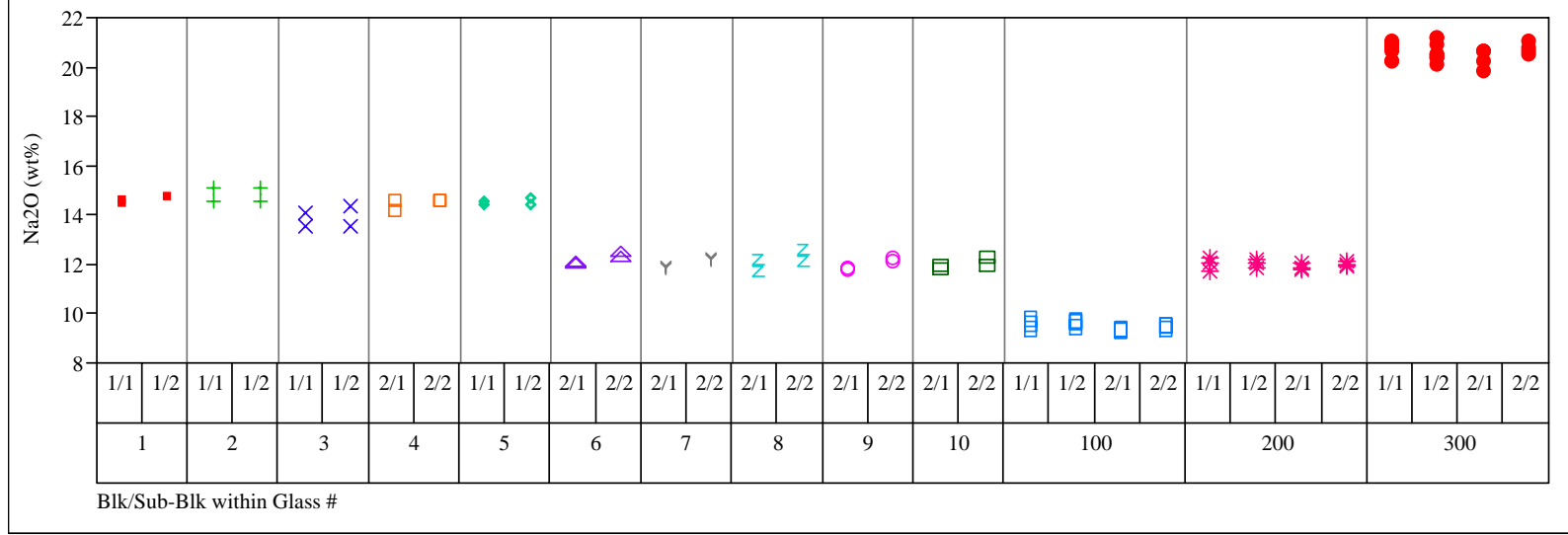

Variability Chart for $\mathrm{NiO}$ (wt\%)

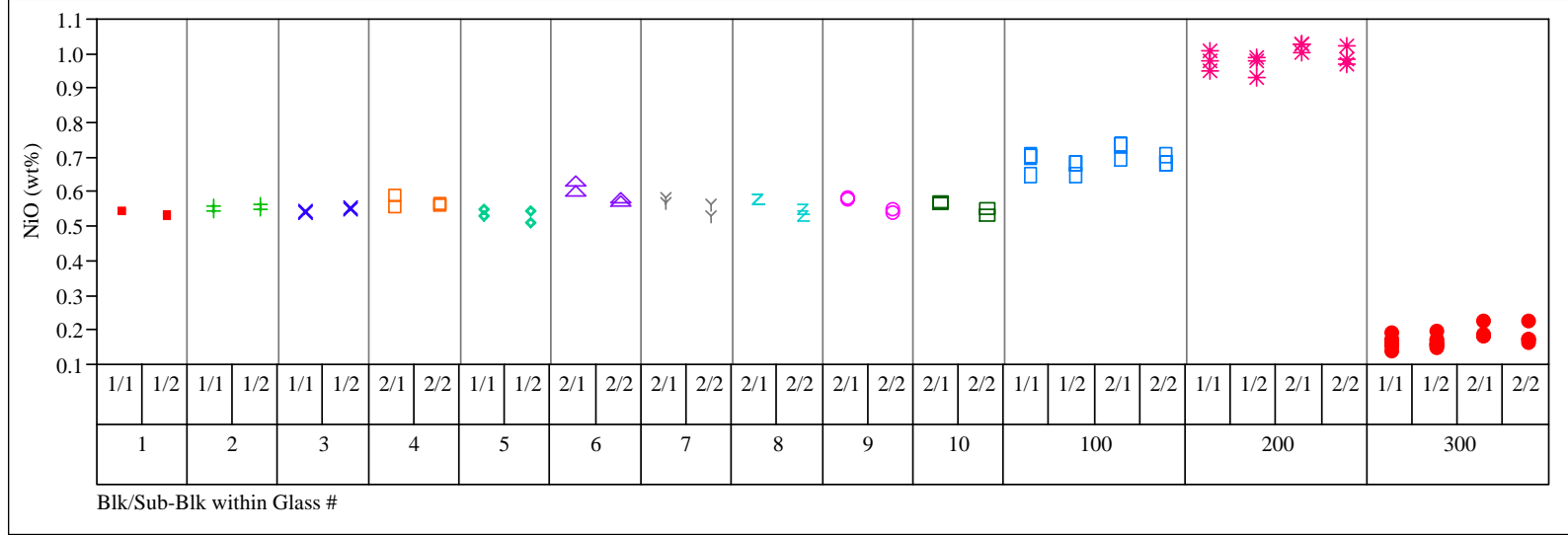


Exhibit B5. Measured and Measured Bias-Corrected Oxide Weight Percents by Glass ID for the Glasses Prepared Using the LM Method (continued) (100 - Batch 1; 200 - Ustd)

Variability Chart for PbO (wt\%)

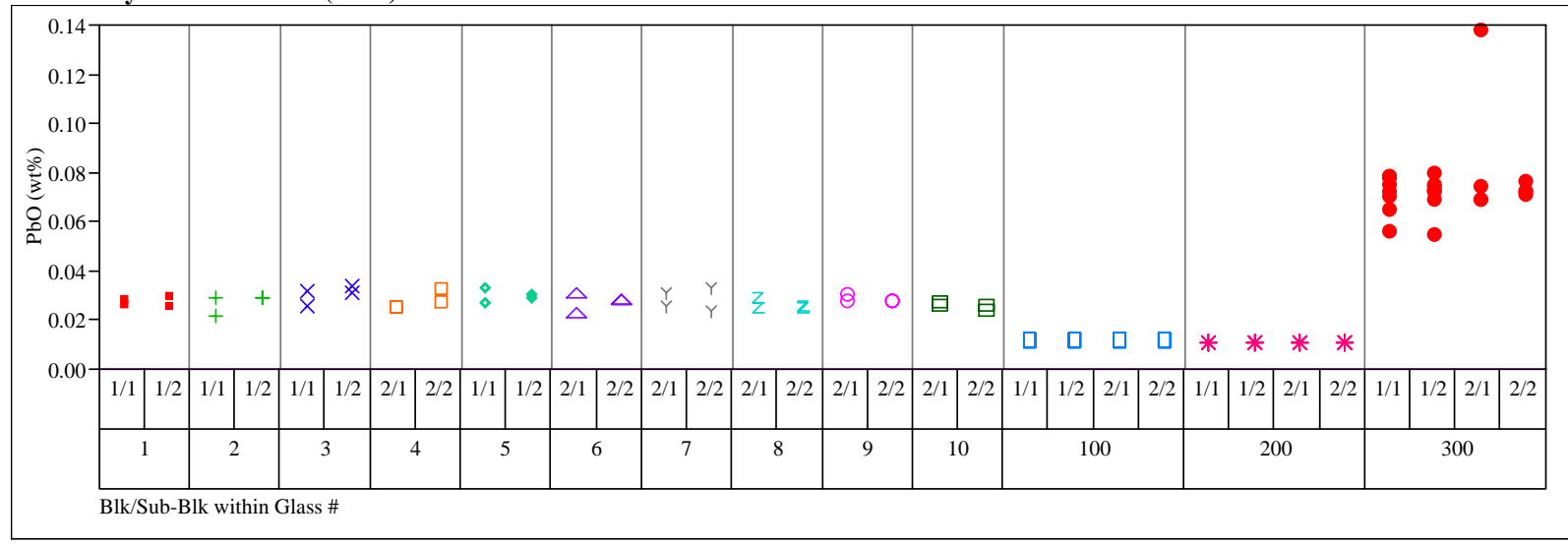

Variability Chart for SO4 (wt\%)

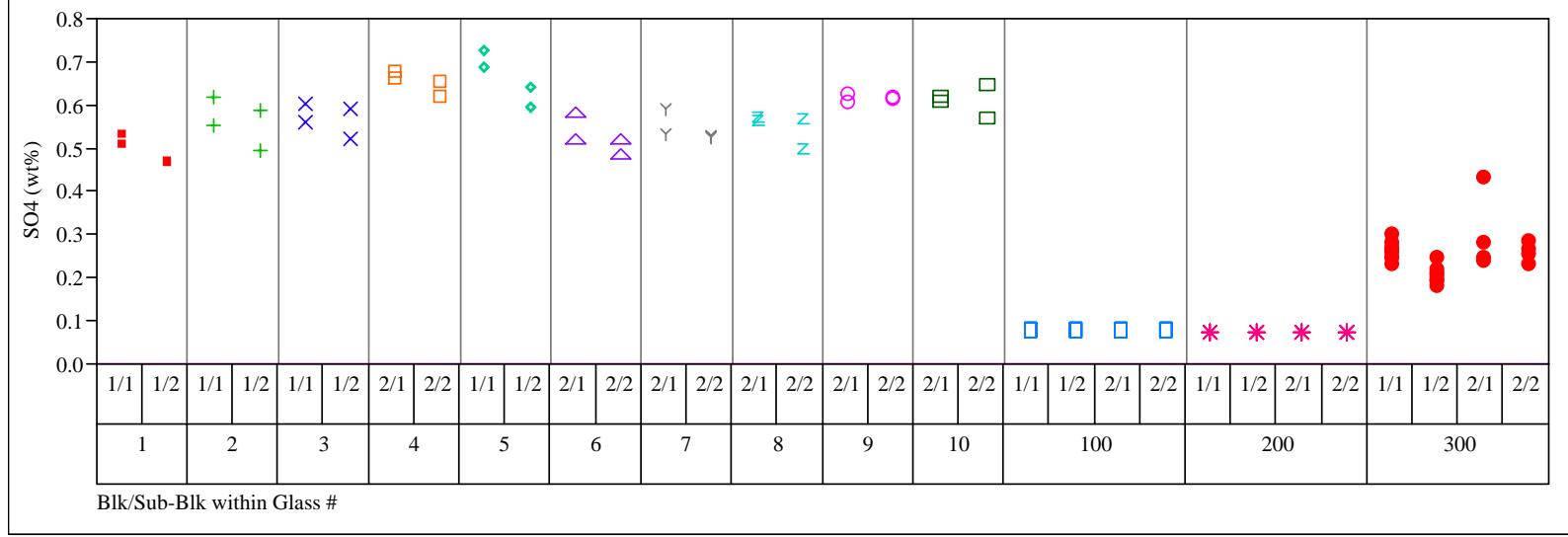

Variability Chart for ThO2 (wt \%)

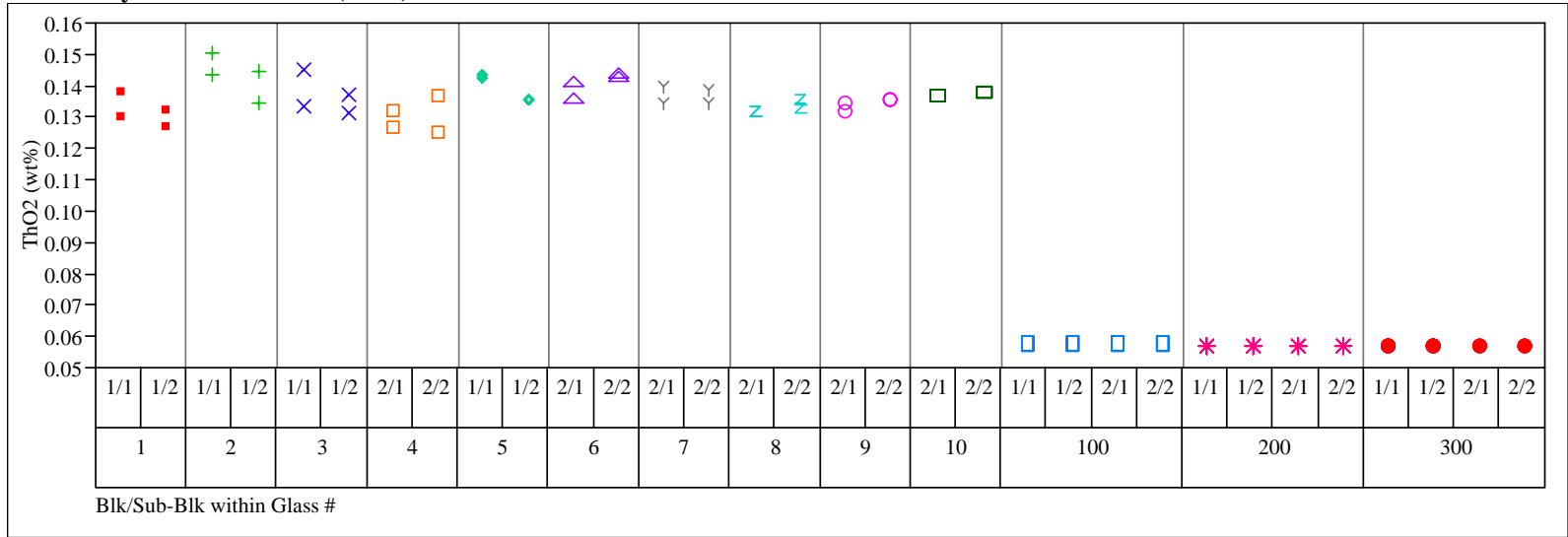


Exhibit B5. Measured and Measured Bias-Corrected Oxide Weight Percents by Glass ID for the Glasses Prepared Using the LM Method (continued) (100 - Batch 1; 200 - Ustd)

Variability Chart for TiO2 (wt\%)

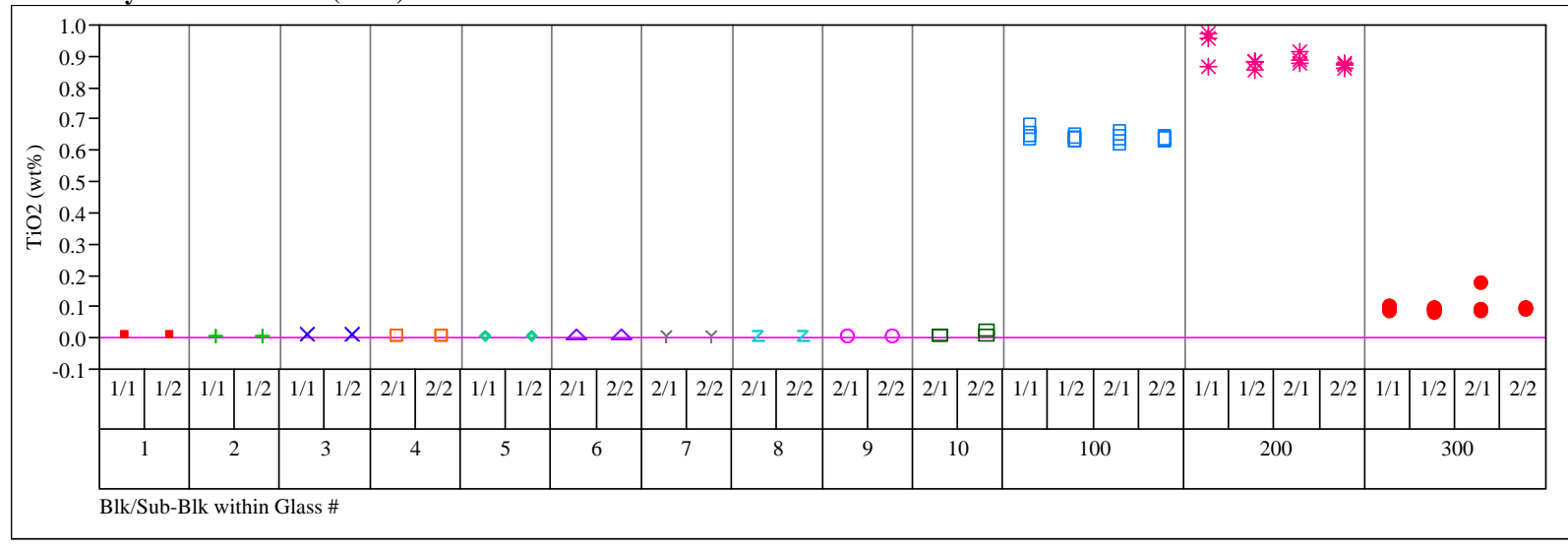

Variability Chart for ZnO (wt\%)

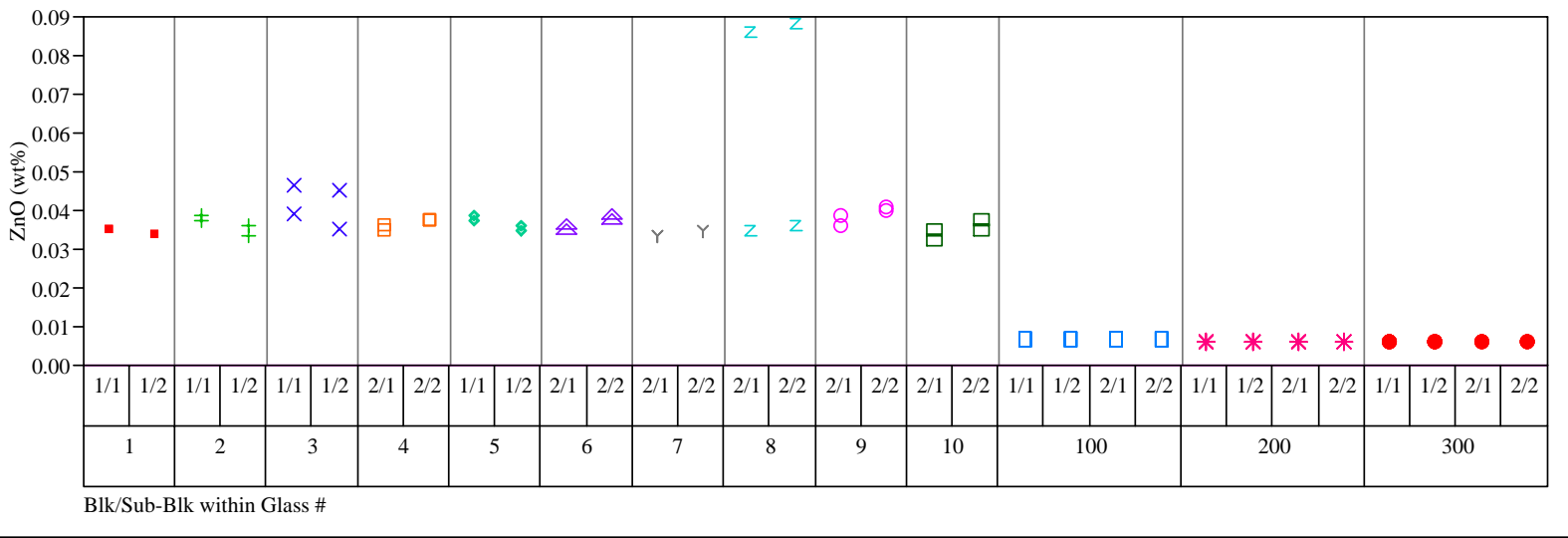

Variability Chart for ZrO2 (wt\%)

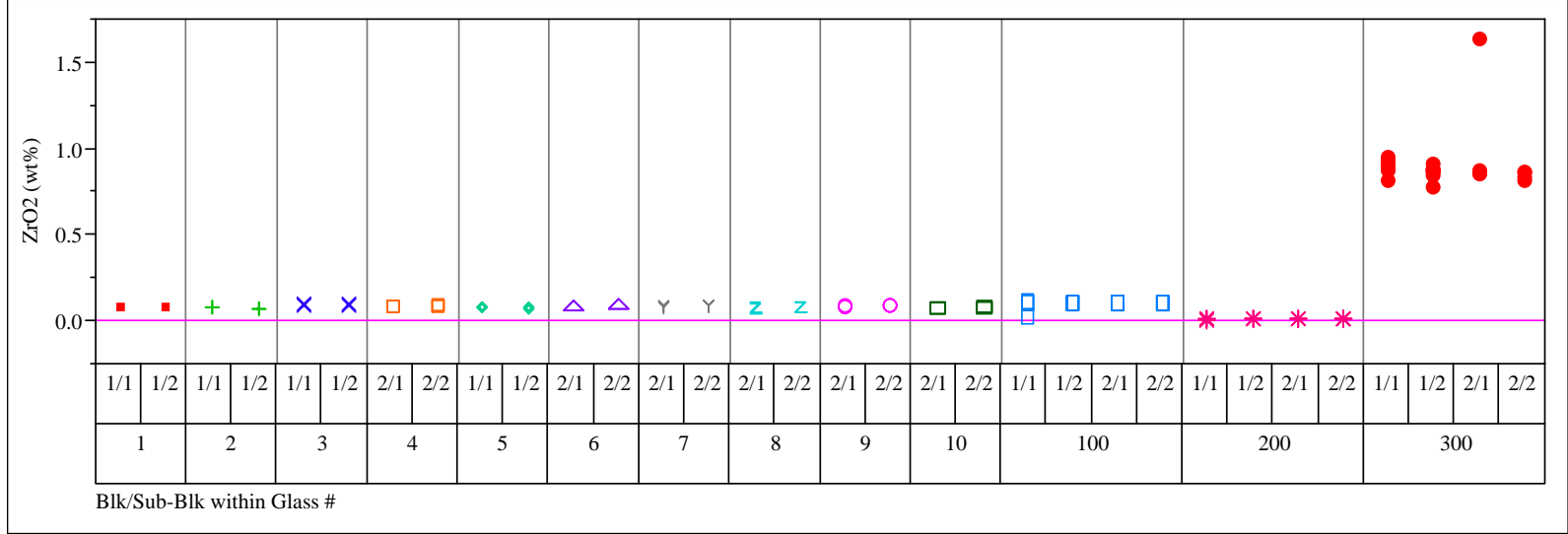


Exhibit B5. Measured and Measured Bias-Corrected Oxide Weight Percents by Glass ID for the Glasses Prepared Using the LM Method (continued)

Variability Chart for Al2O3 bc (wt\%)

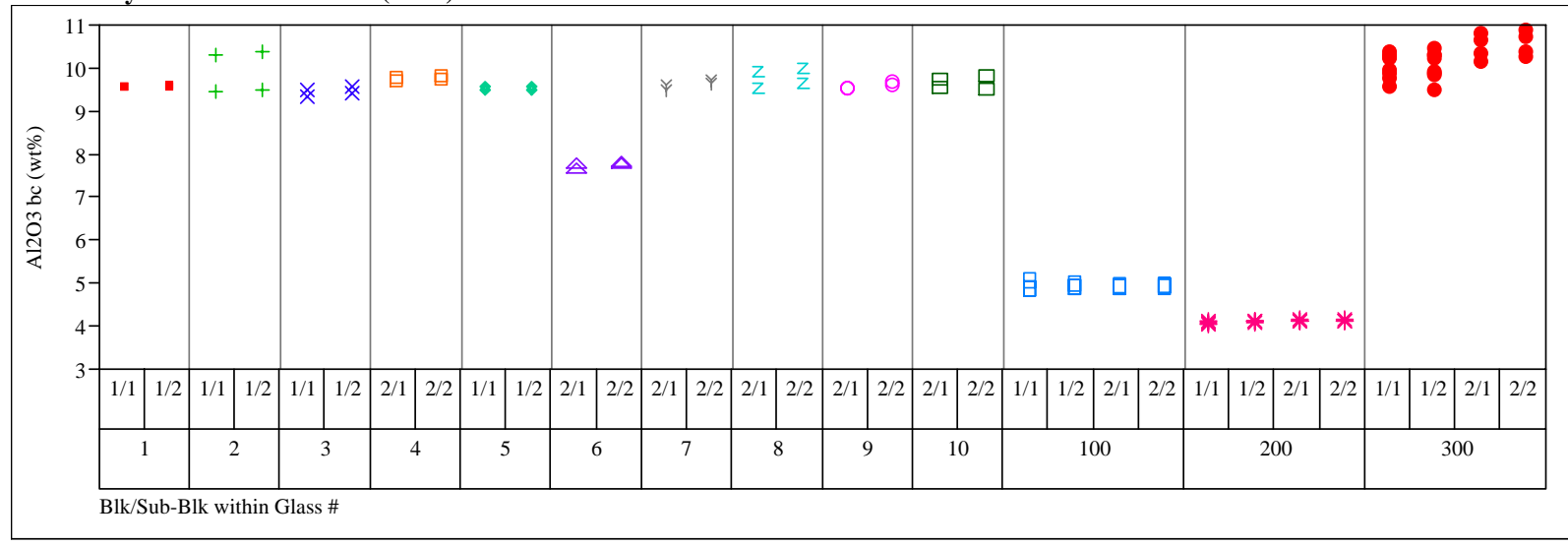

Variability Chart for BaO bc (wt\%)

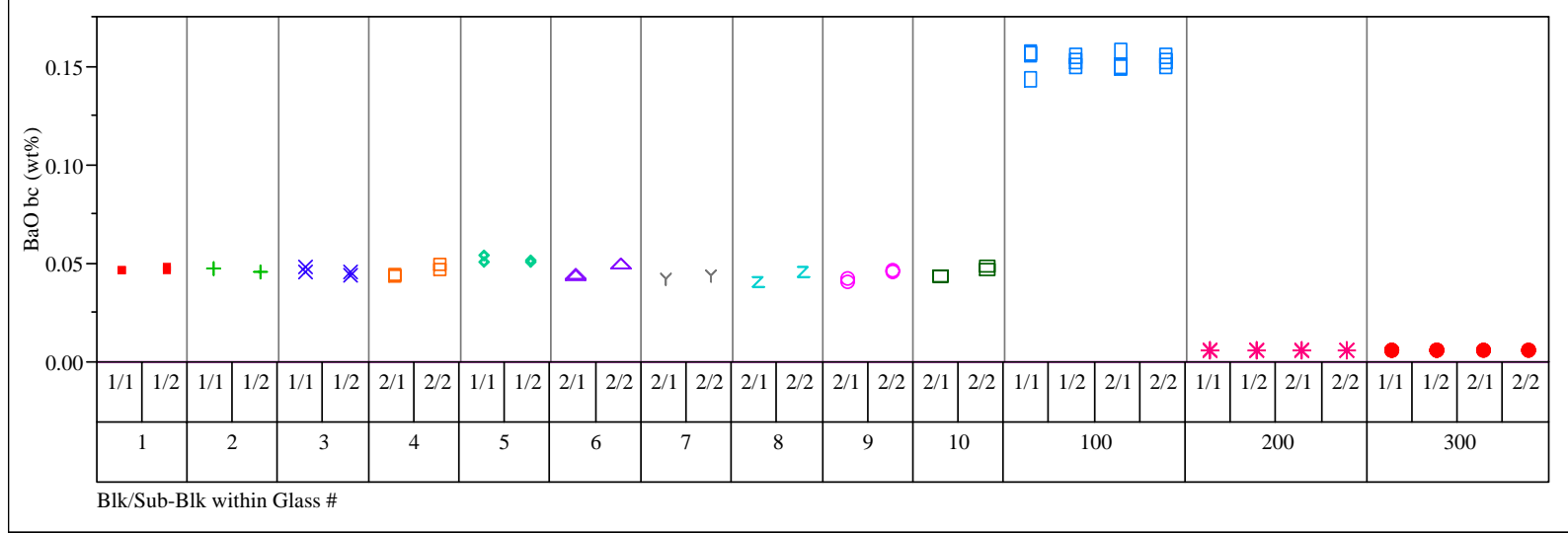

Variability Chart for CaO bc (wt\%)

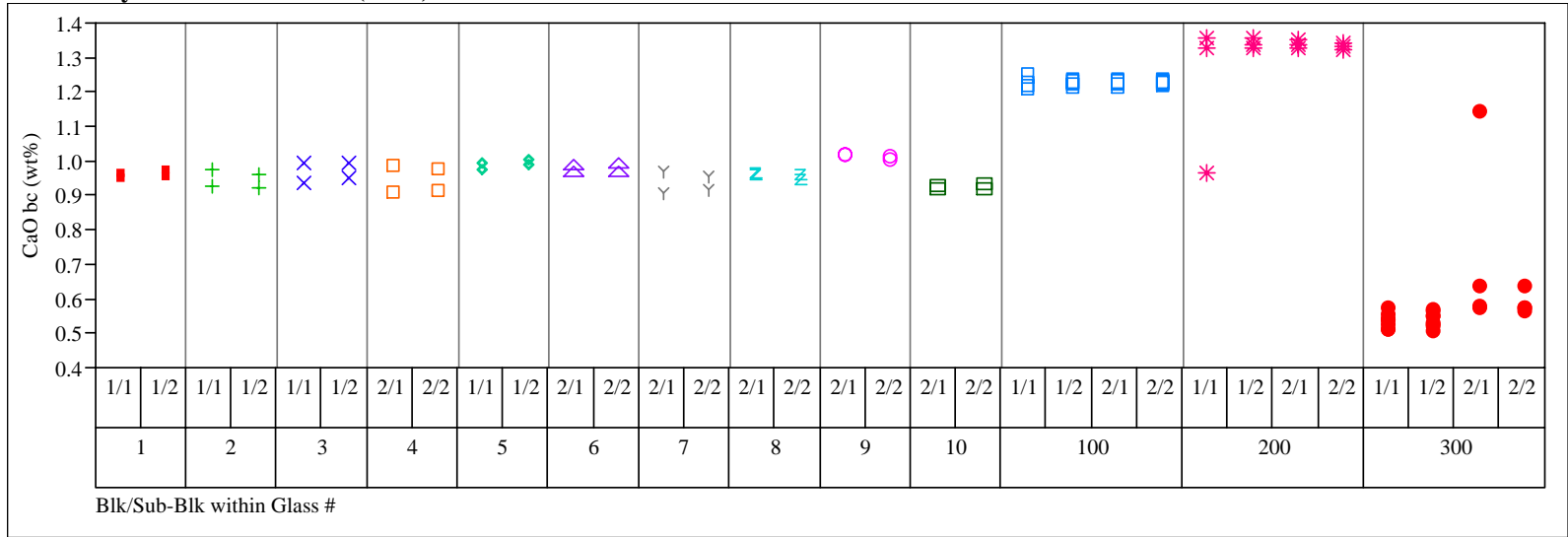


Exhibit B5. Measured and Measured Bias-Corrected Oxide Weight Percents by Glass ID for the Glasses Prepared Using the LM Method (continued) (100 - Batch 1; 200 - Ustd)

Variability Chart for Ce2O3 bc (wt\%)

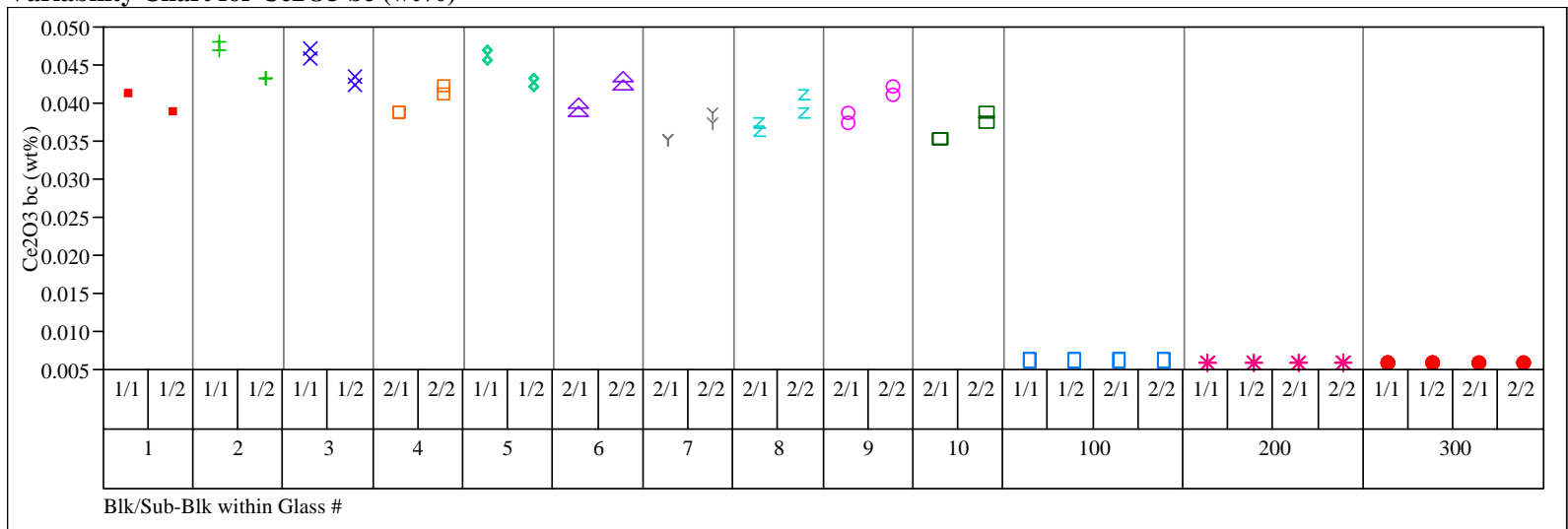

Variability Chart for Cr2O3 bc (wt\%)

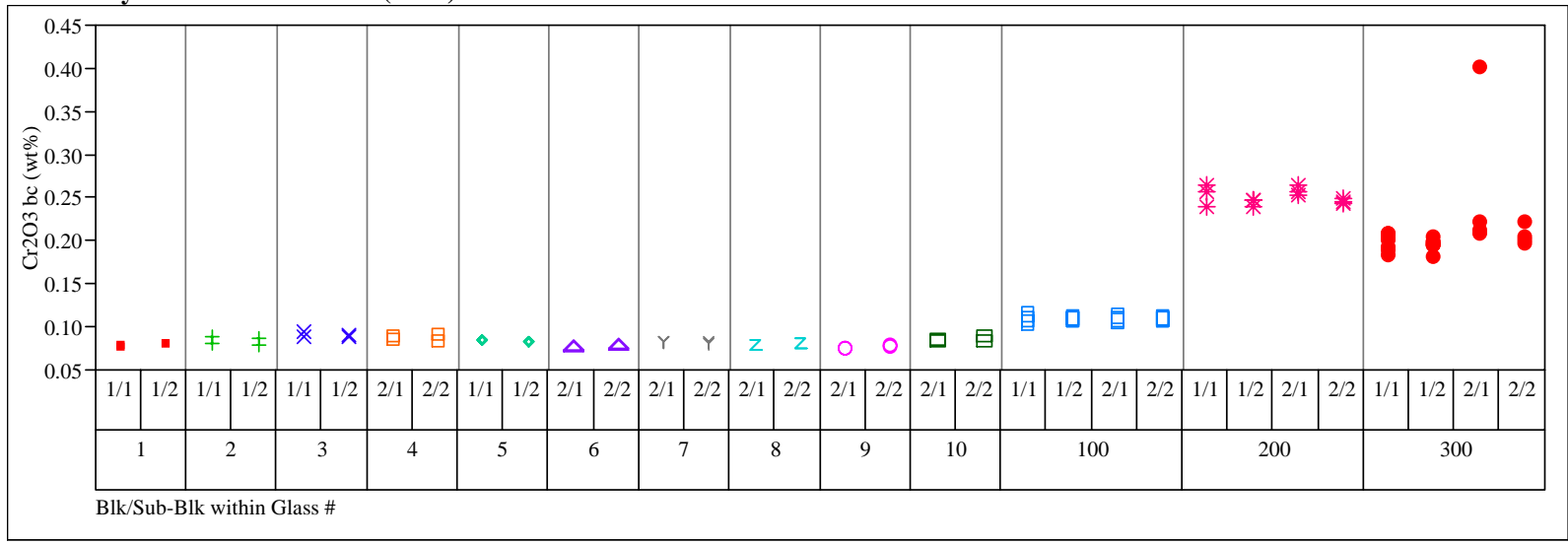

Variability Chart for $\mathrm{CuO}$ bc (wt\%)

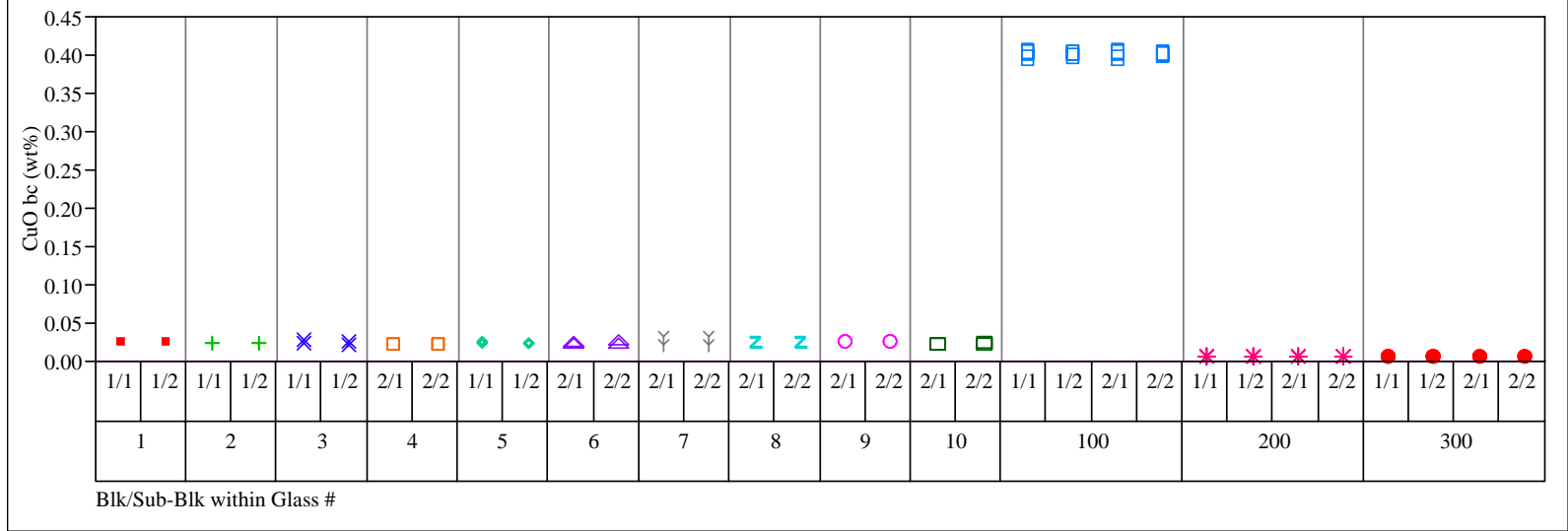


Exhibit B5. Measured and Measured Bias-Corrected Oxide Weight Percents by Glass ID for the Glasses Prepared Using the LM Method (continued) (100 - Batch 1; 200 - Ustd)

Variability Chart for K2O bc (wt\%)

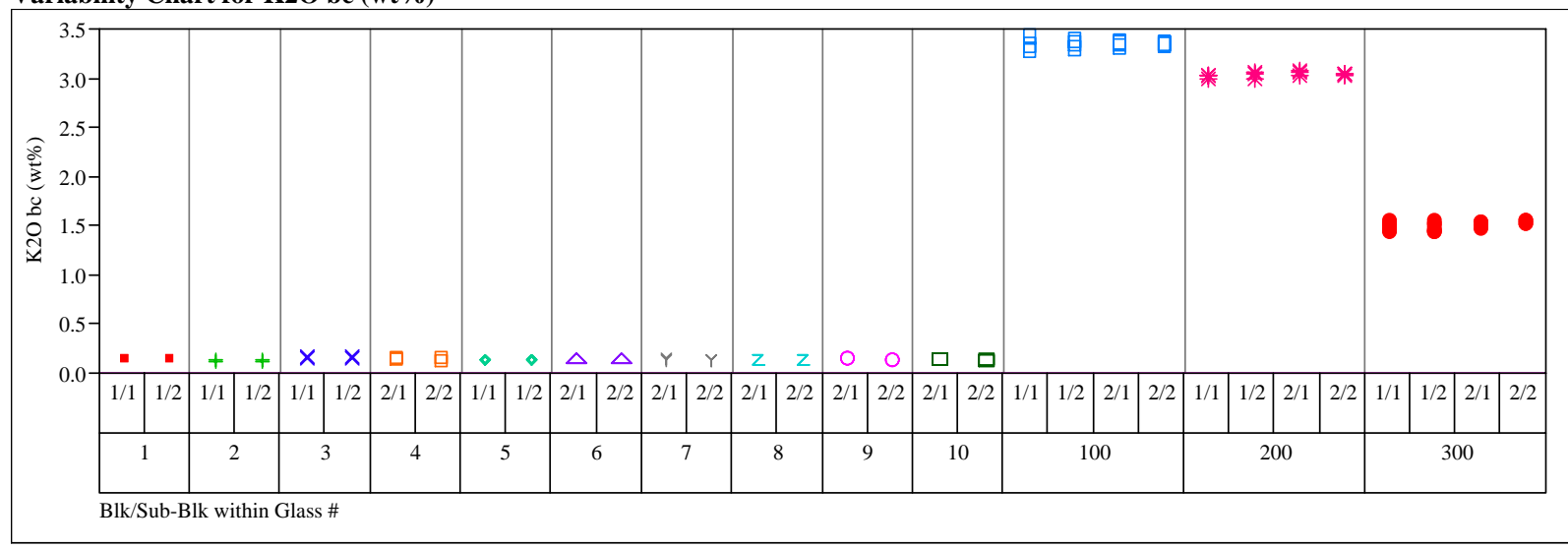

Variability Chart for La2O3 bc (wt\%)

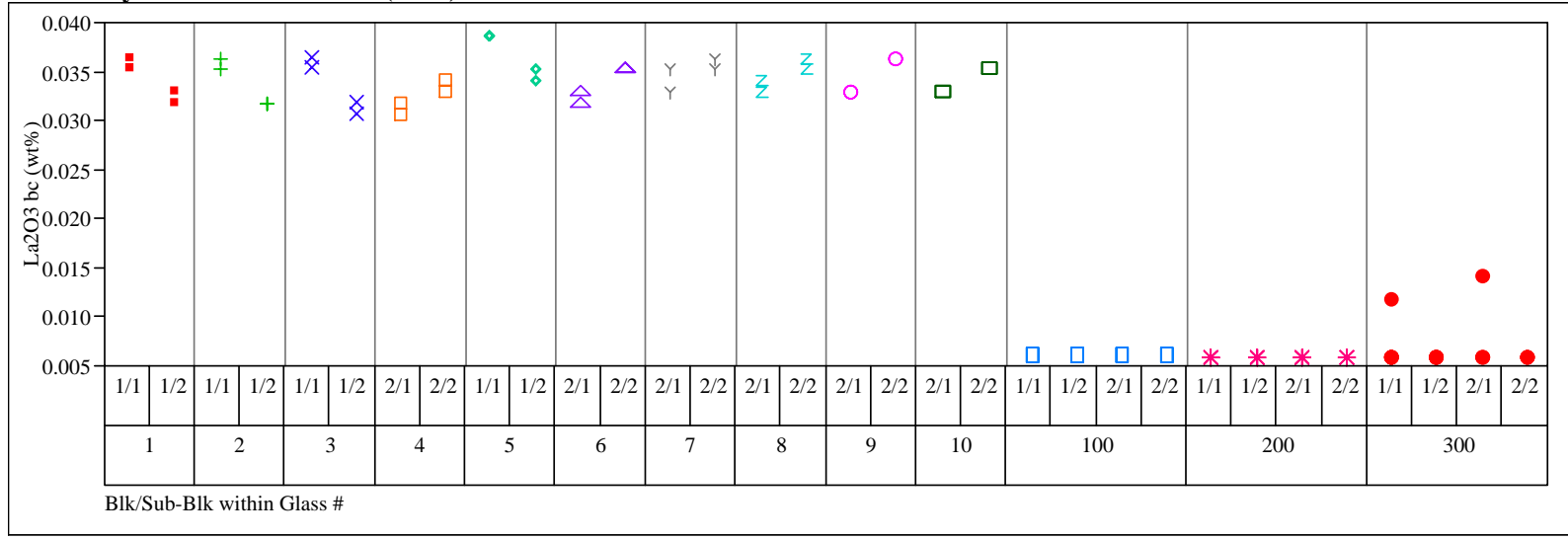

Variability Chart for MgO bc (wt\%)

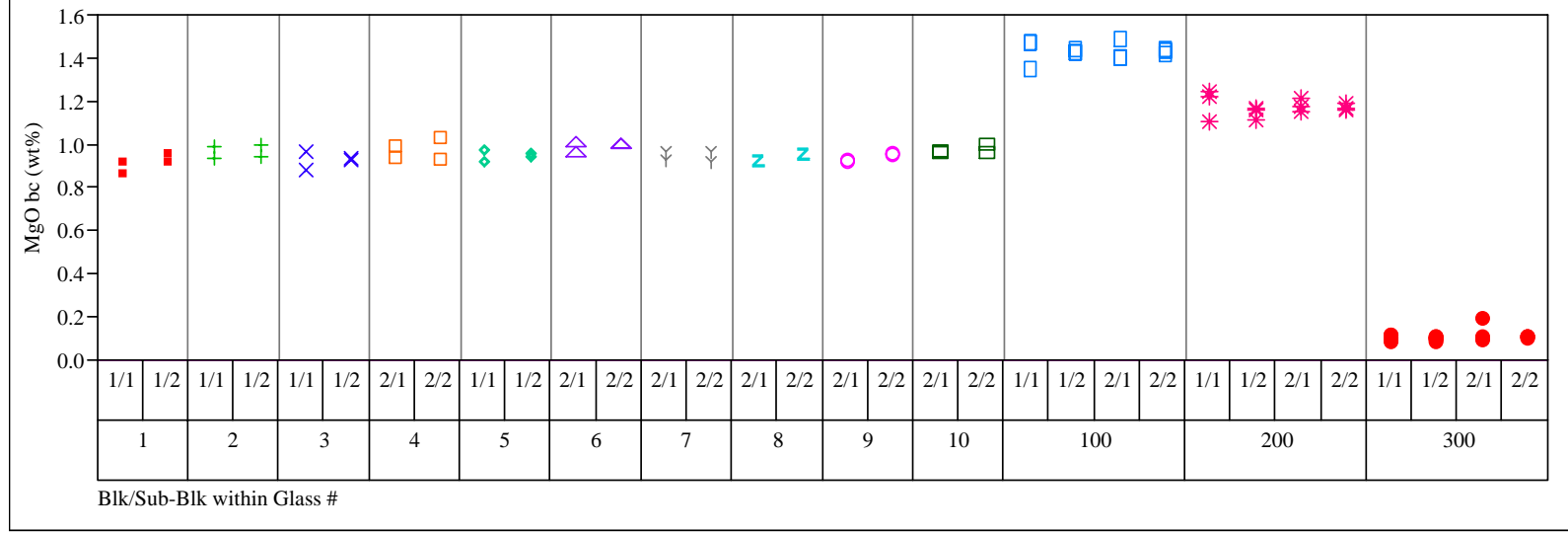


Exhibit B5. Measured and Measured Bias-Corrected Oxide Weight Percents by Glass ID for the Glasses Prepared Using the LM Method (continued) (100 - Batch 1; 200 - Ustd)

Variability Chart for MnO bc (wt\%)

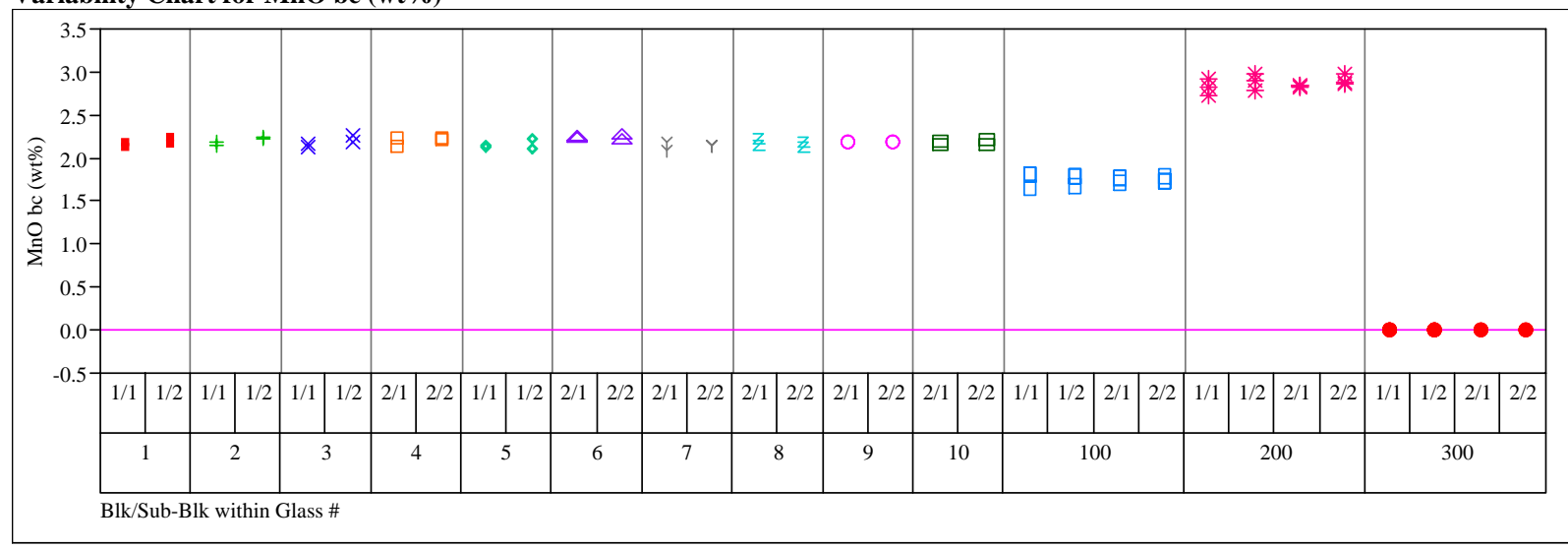

Variability Chart for Na2O bc (wt\%)

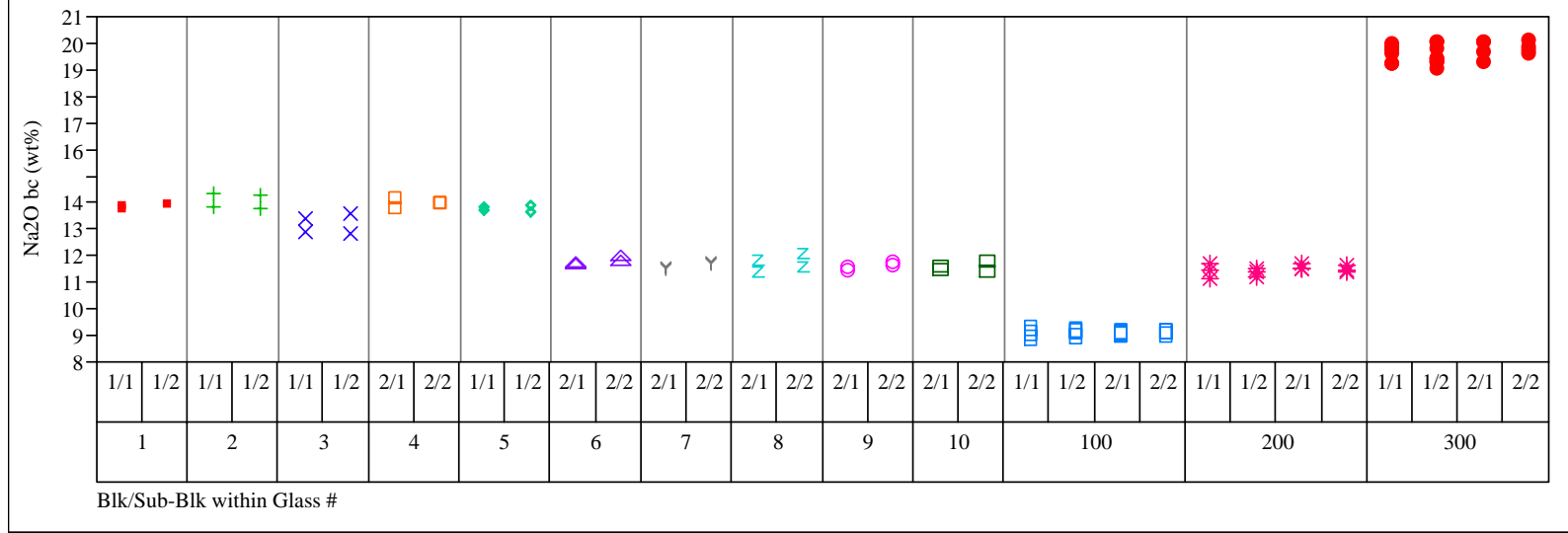

Variability Chart for NiO bc (wt\%)

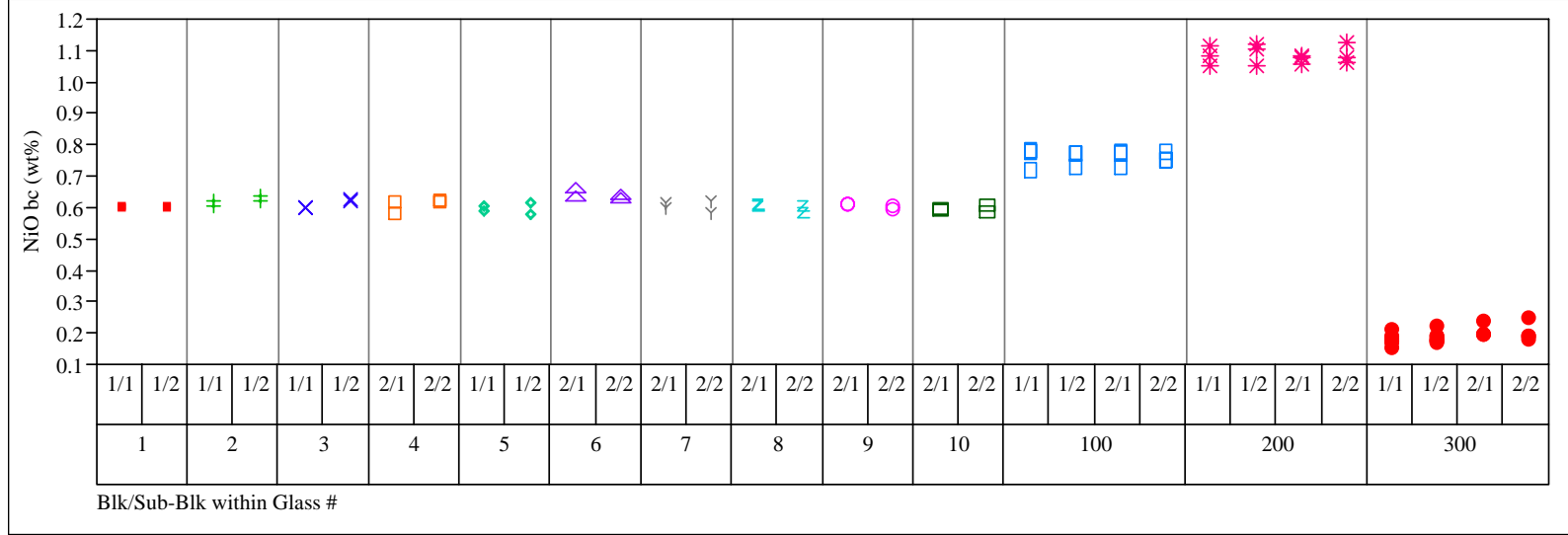


Exhibit B5. Measured and Measured Bias-Corrected Oxide Weight Percents by Glass ID for the Glasses Prepared Using the LM Method (continued) (100 - Batch 1; 200 - Ustd)

Variability Chart for PbO bc (wt\%)

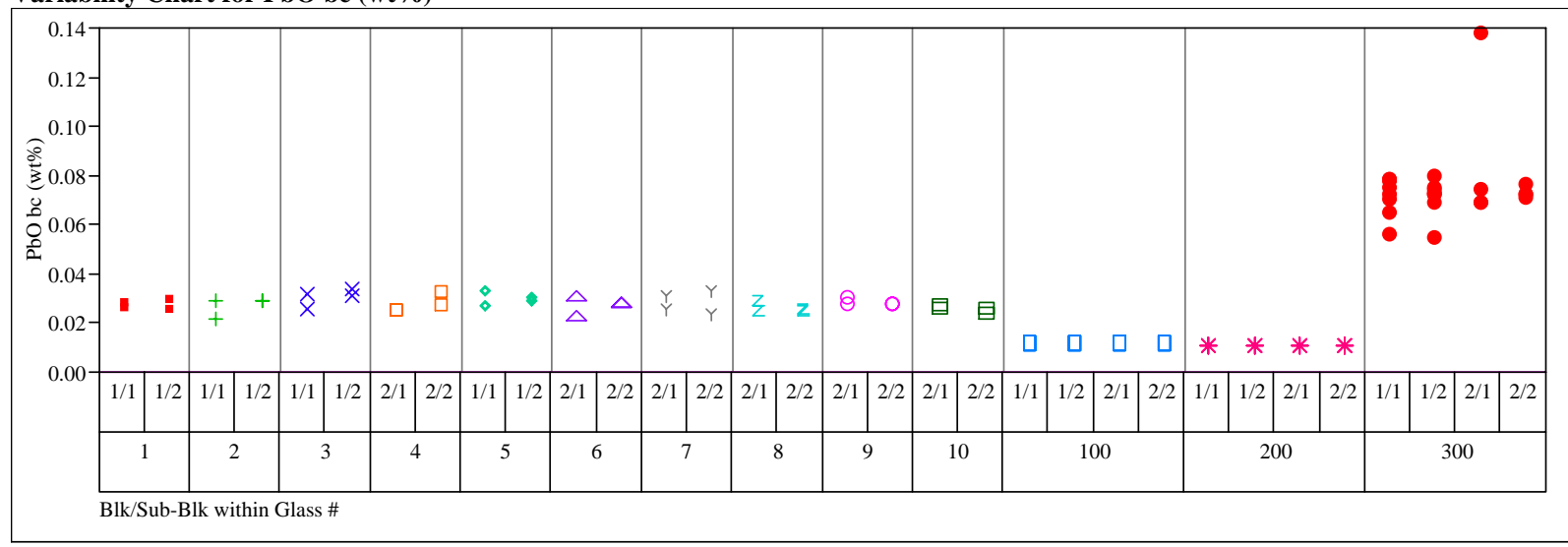

Variability Chart for SO4 bc (wt\%)

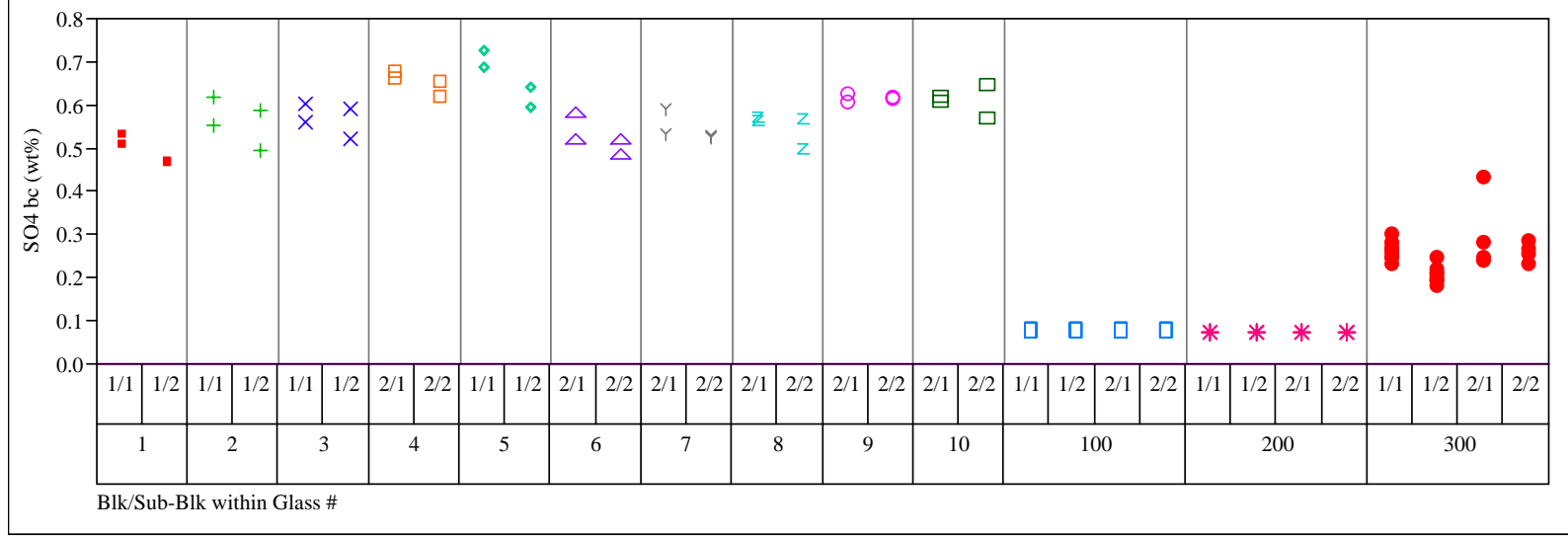

Variability Chart for ThO2 bc (wt\%)

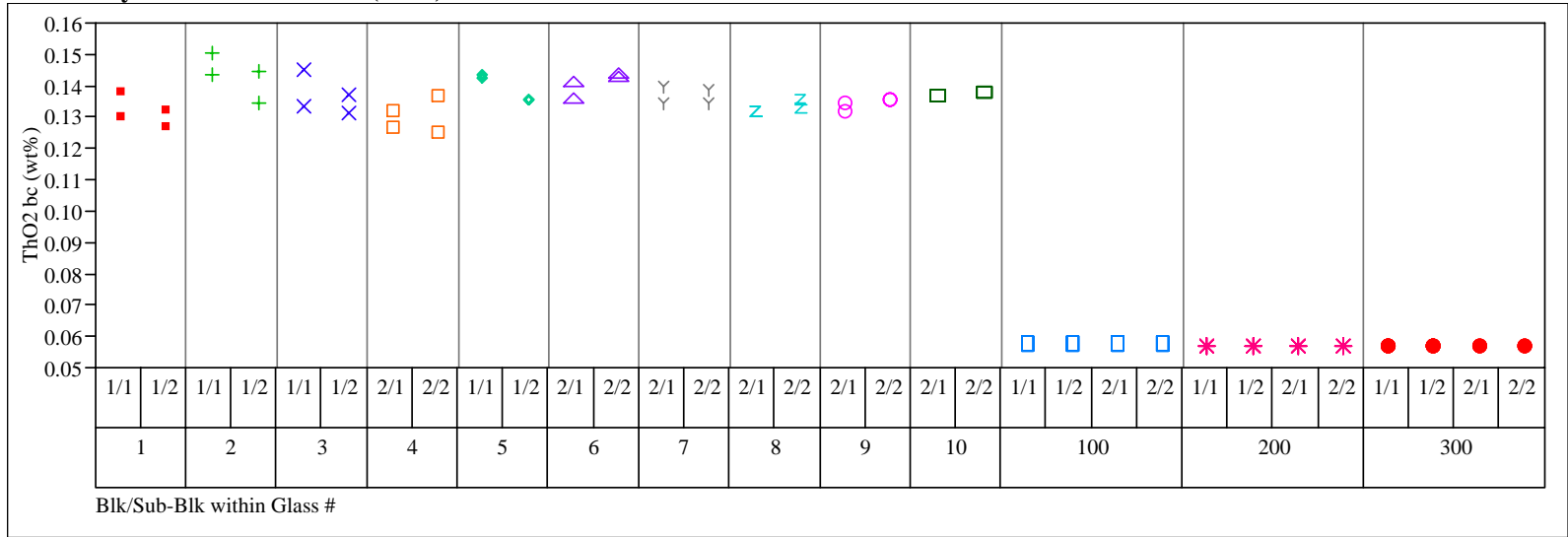


Exhibit B5. Measured and Measured Bias-Corrected Oxide Weight Percents by Glass ID for the Glasses Prepared Using the LM Method (continued)

Variability Chart for TiO2 bc (wt\%)

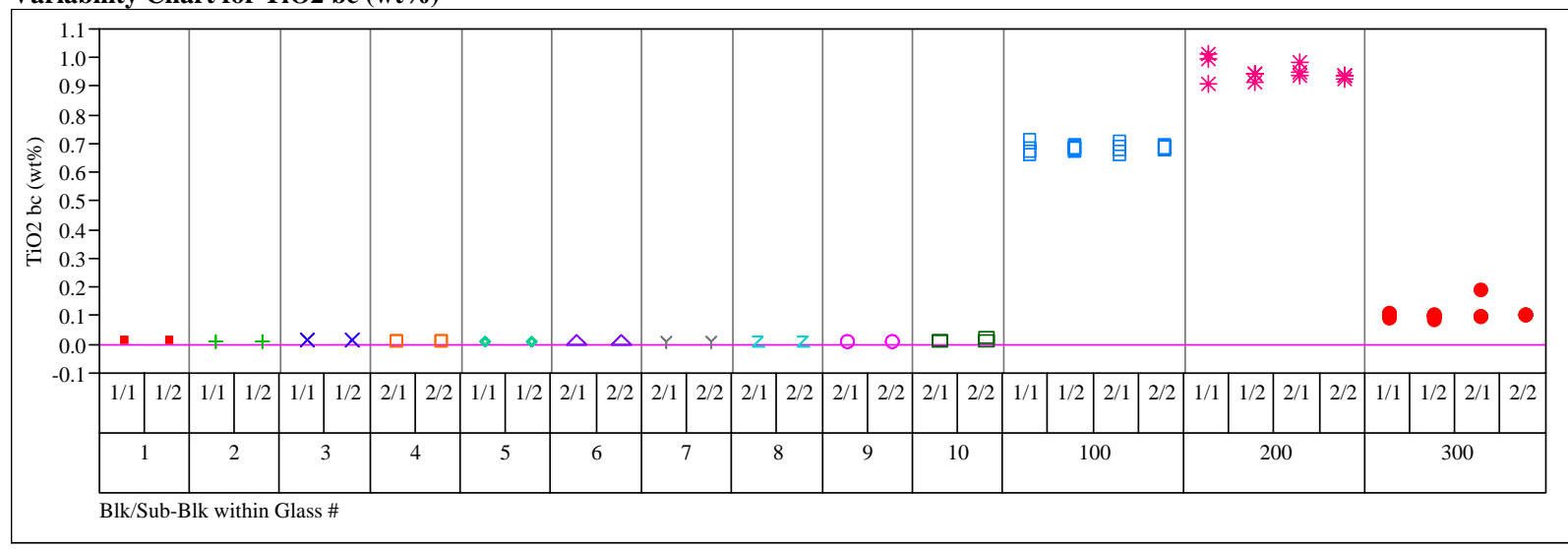

Variability Chart for $\mathrm{ZnO}$ bc (wt\%)

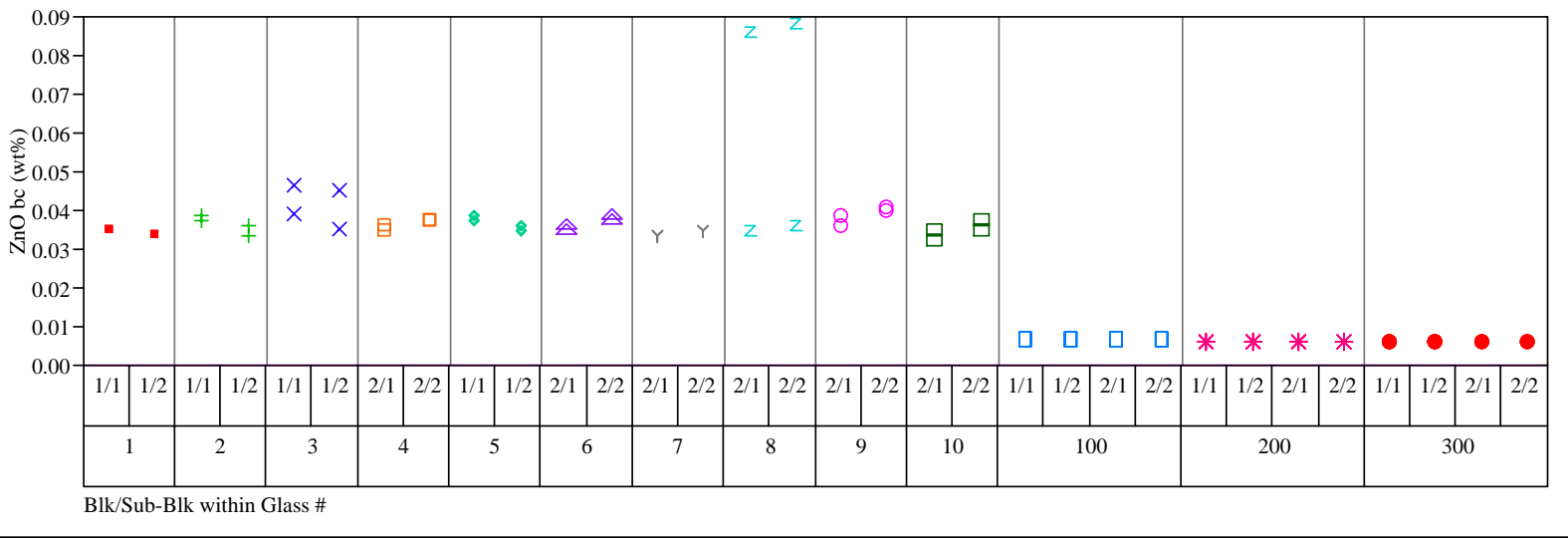

Variability Chart for ZrO2 bc (wt\%)

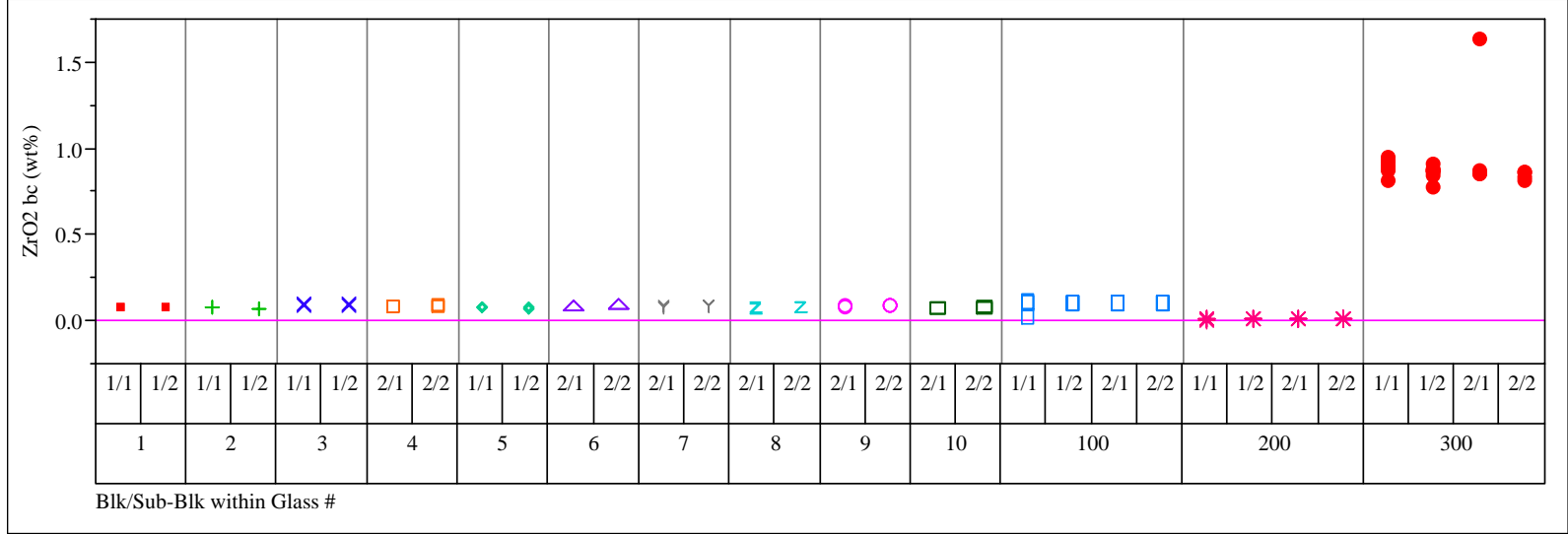


Exhibit B6. Measured and Measured Bias-Corrected Oxide Weight Percents by Glass \# for the Glasses Prepared Using the PF Method

(100 - Batch 1; 200 - Ustd)

Variability Chart for B2O3 (wt\%)

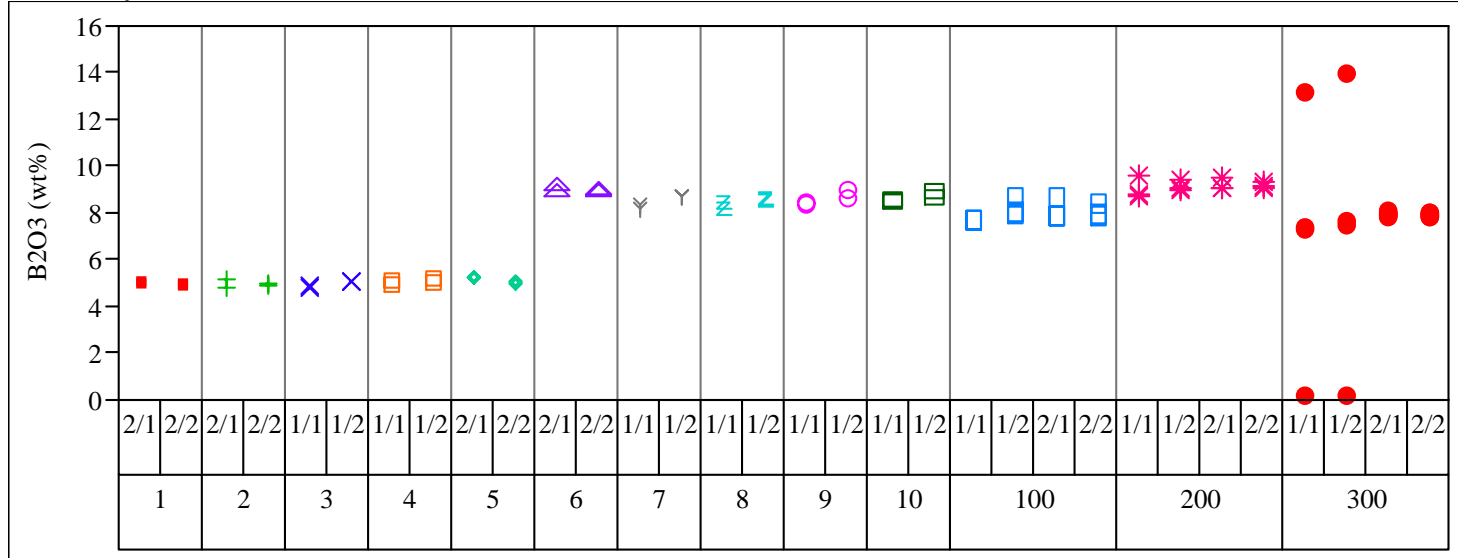

Blk/ Sub-Blk within Glass \#

Variability Chart for Fe2O3 (wt \%)

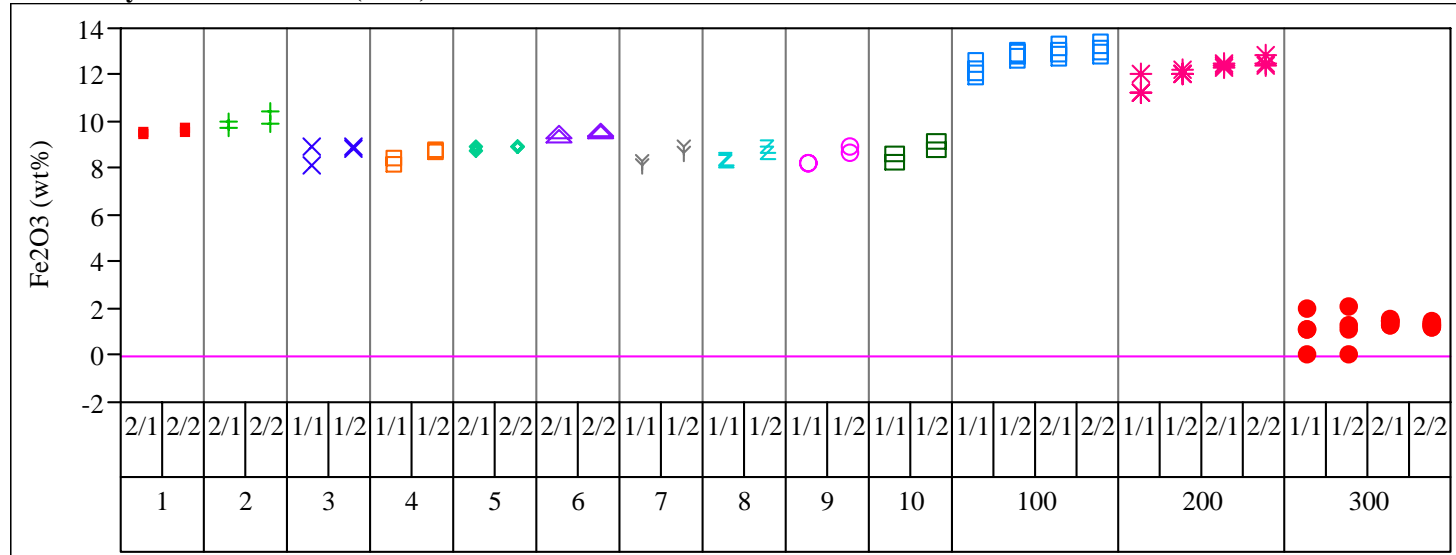

Blk/ Sub-Blk within Glass \#

Variability Chart for Li2O (wt \%)

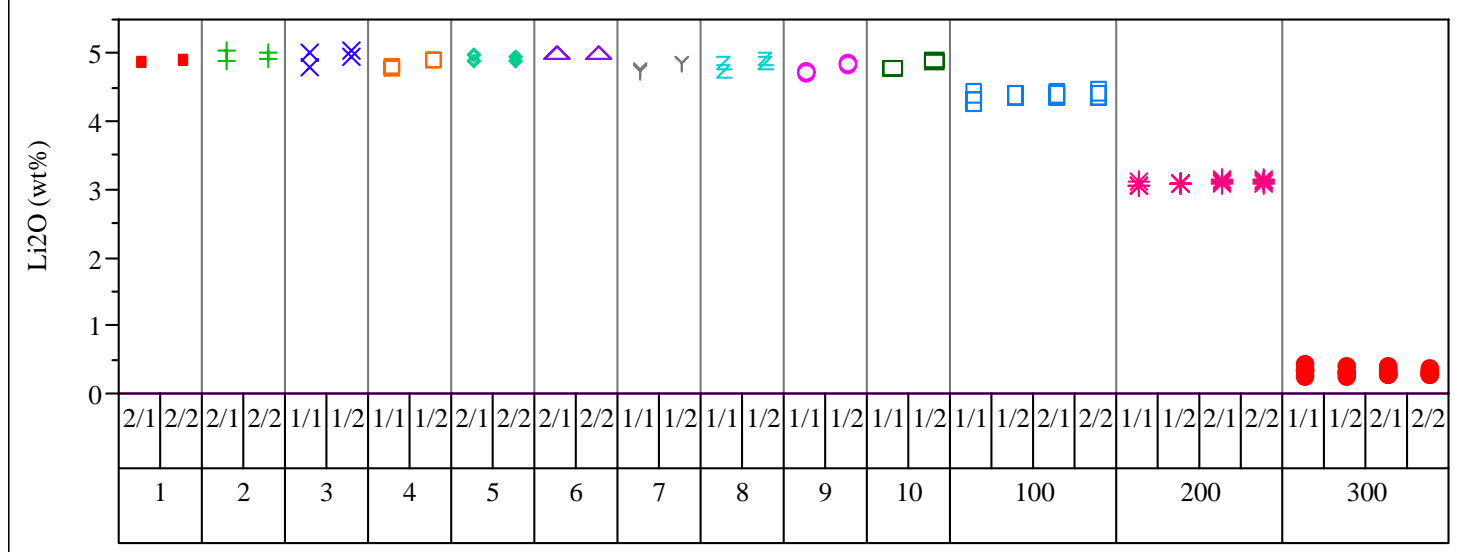

Blk/ Sub-Blk within Glass \# 
Exhibit B6. Measured and Measured Bias-Corrected Oxide Weight Percents by Glass \# for the Glasses Prepared Using the PF Method (continued)

(100 - Batch 1; 200 - Ustd)

Variability Chart for SiO2 (wt\%)

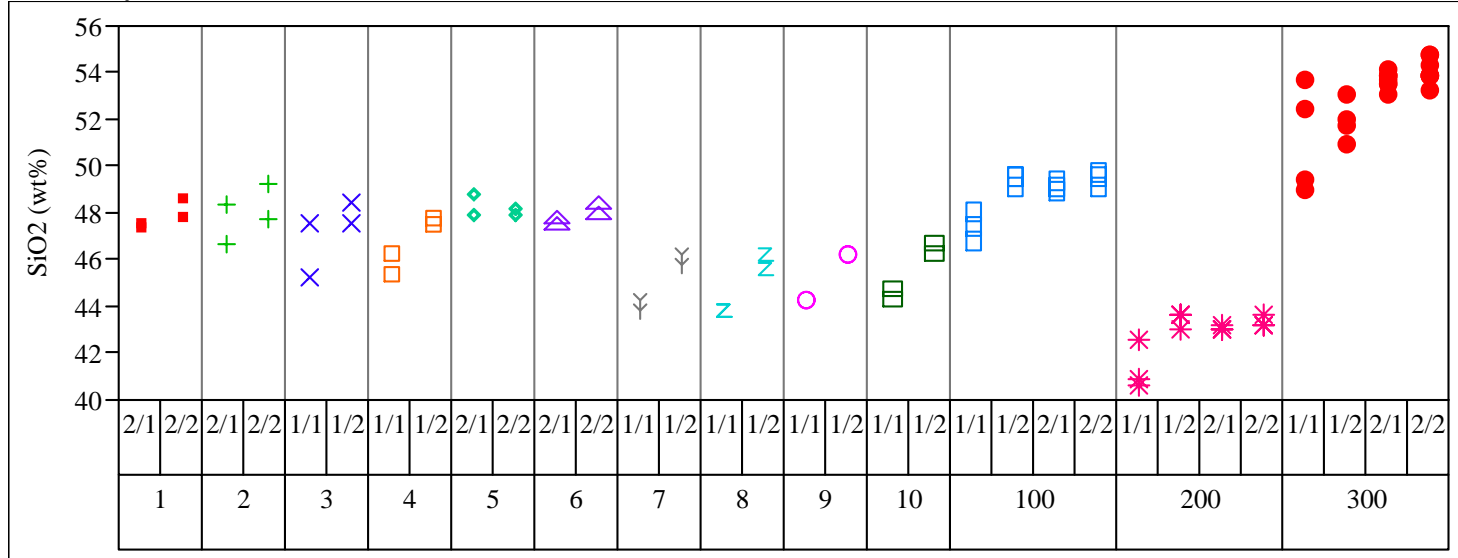

Blk/ Sub-Blk within Glass \#

Variability Chart for U3O8 (wt \%)

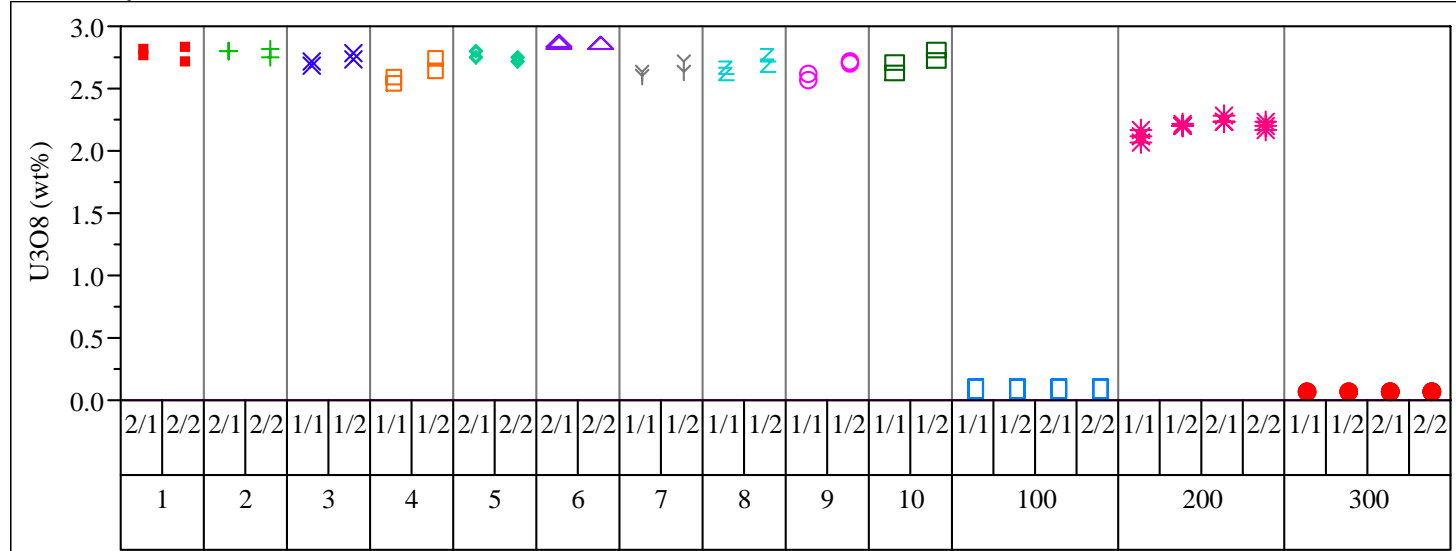

Blk/ Sub-Blk within Glass \#

Variability Chart for B2O3 bc (wt\%)

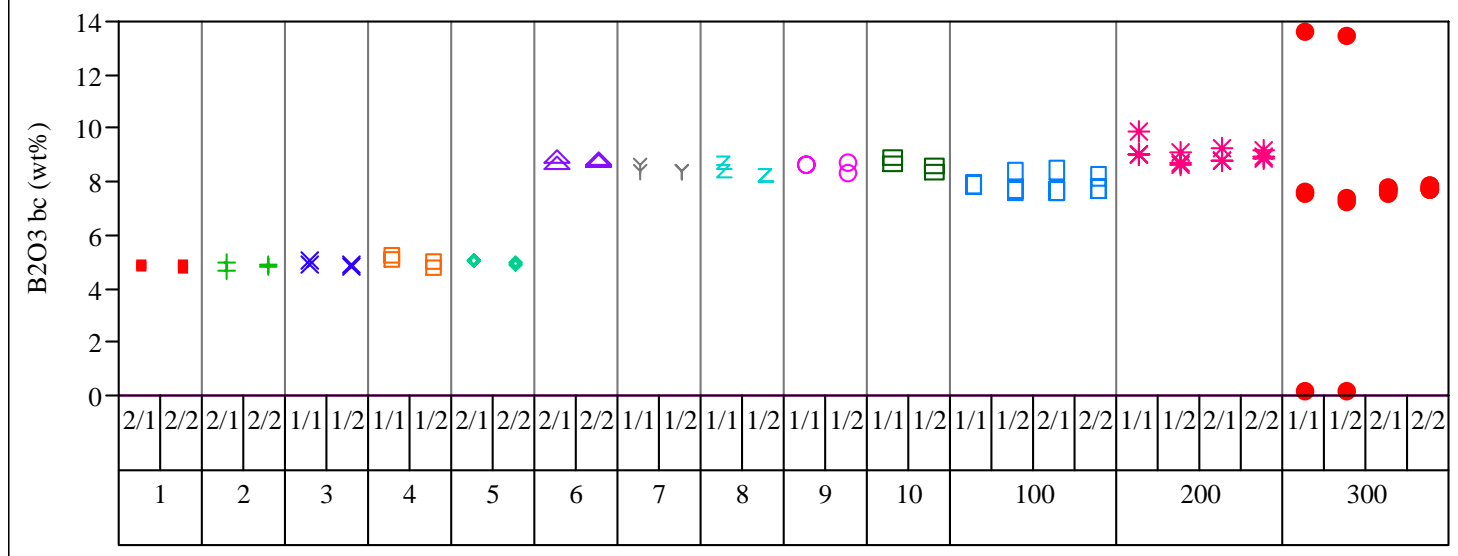

Blk/ Sub-Blk within Glass \# 
Exhibit B6. Measured and Measured Bias-Corrected Oxide Weight Percents by Glass \# for the Glasses Prepared Using the PF Method (continued)

(100 - Batch 1; 200 - Ustd)

Variability Chart for Fe2O3 bc (wt\%)

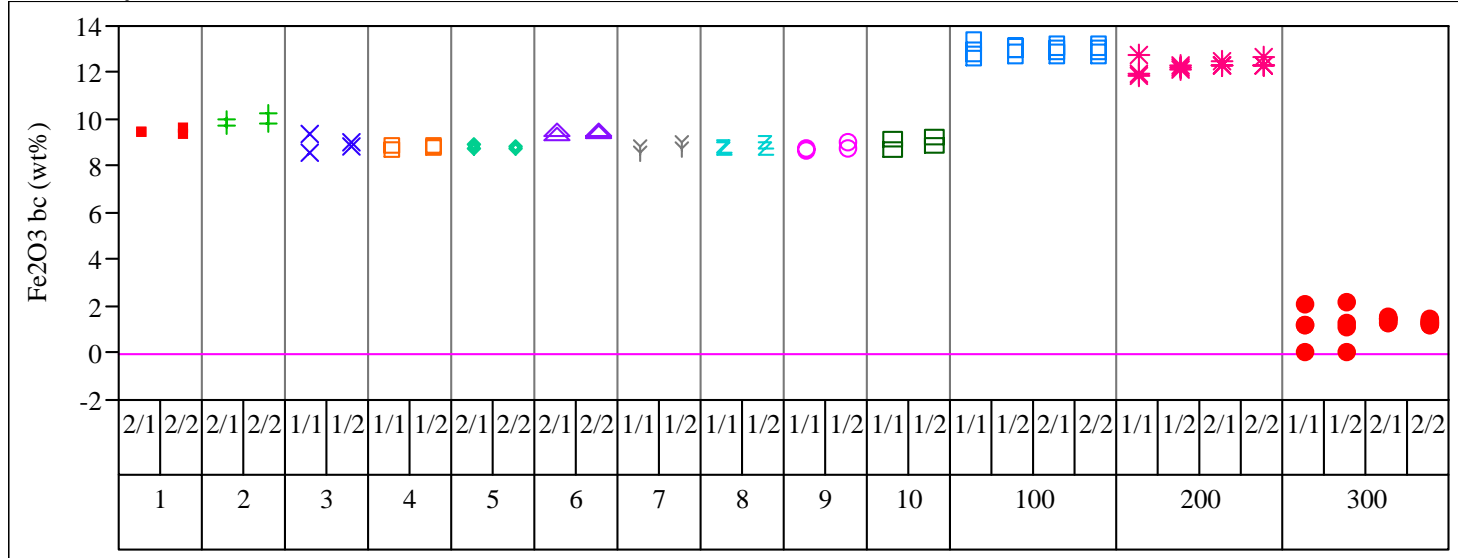

Blk/ Sub-Blk within Glass \#

Variability Chart for Li2O bc (wt\%)

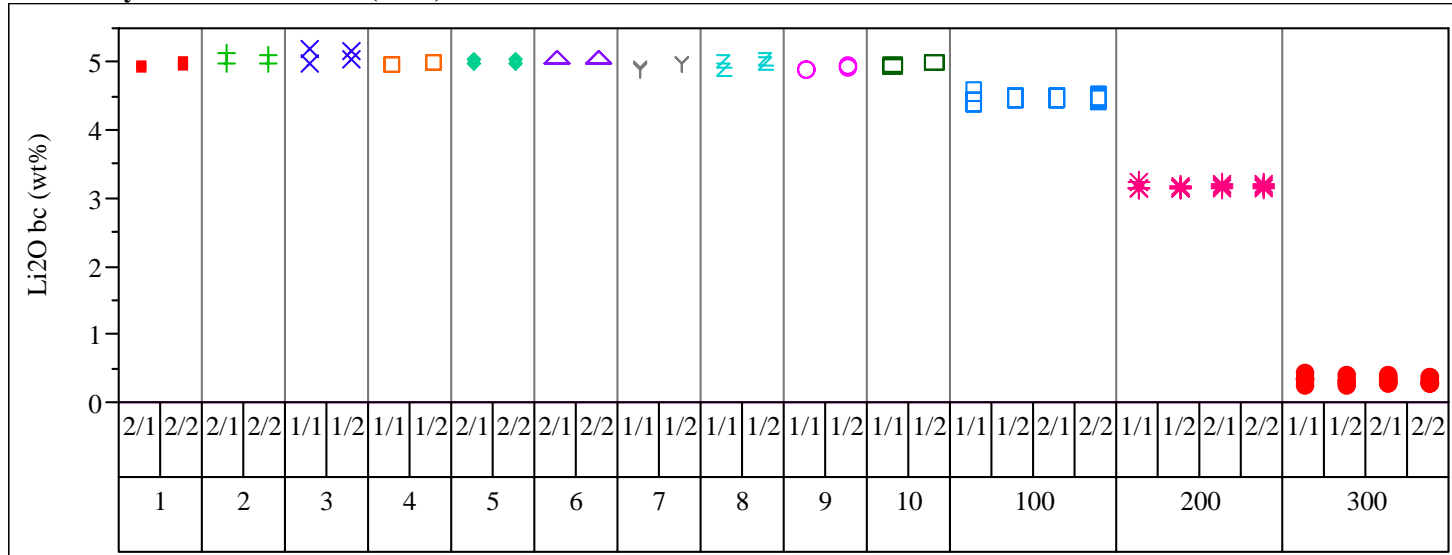

Blk/ Sub-Blk within Glass \#

Variability Chart for SiO2 bc (wt\%)

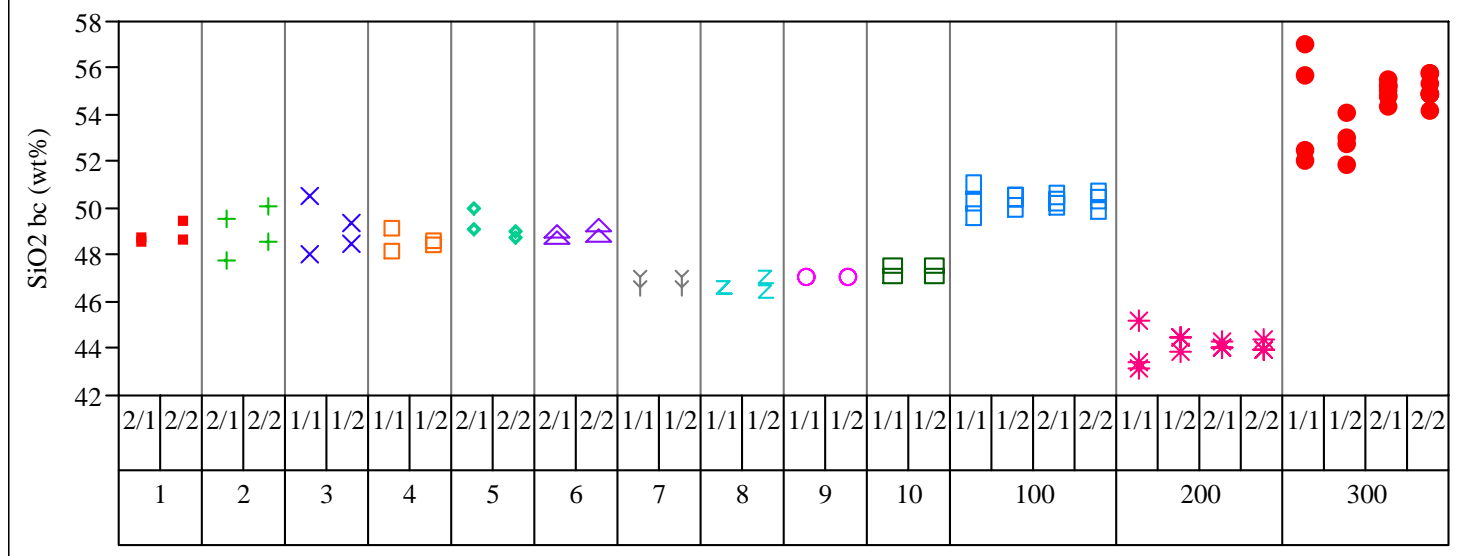

Blk/ Sub-Blk within Glass \# 
Exhibit B6. Measured and Measured Bias-Corrected Oxide Weight Percents by Glass \# for the Glasses Prepared Using the PF Method (continued) (100 - Batch 1; 200 - Ustd)

Variability Chart for U3O8 bc (wt\%)

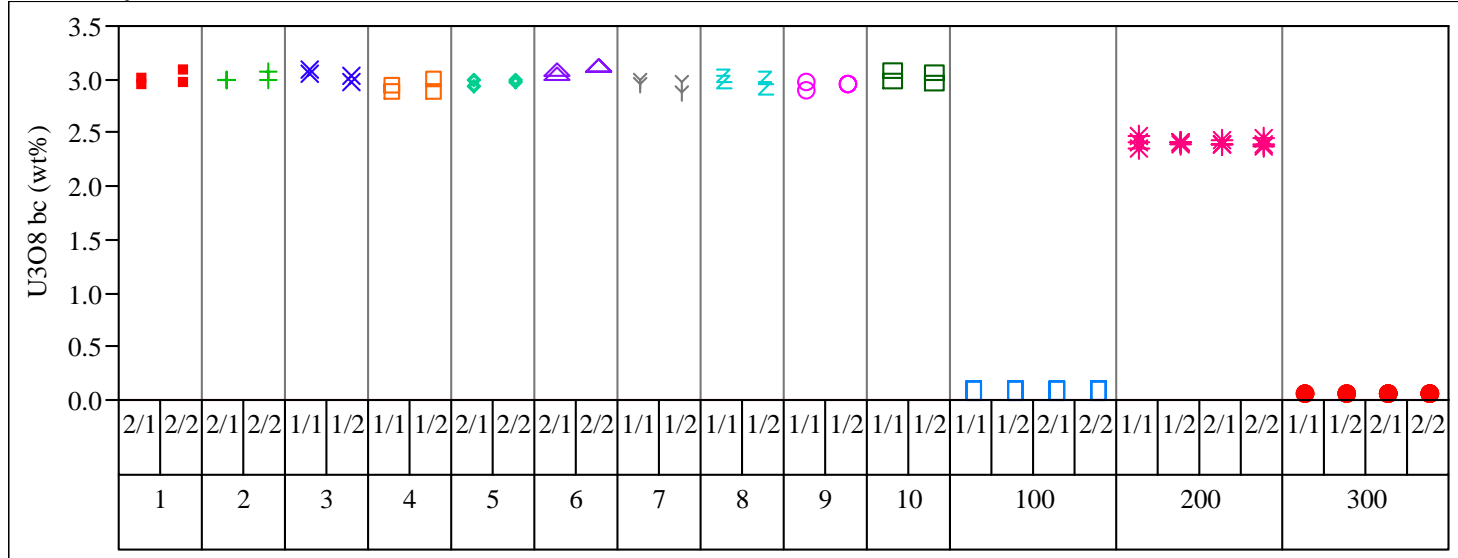

Blk/ Sub-Blk within Glass \# 
Exhibit B7. Average Measured and Bias-Corrected (bc) Versus Targeted Compositions by Glass ID by Oxide

(100 - Batch 1; 200 - Ustd)

Overlay Plot Oxide=Al2O3

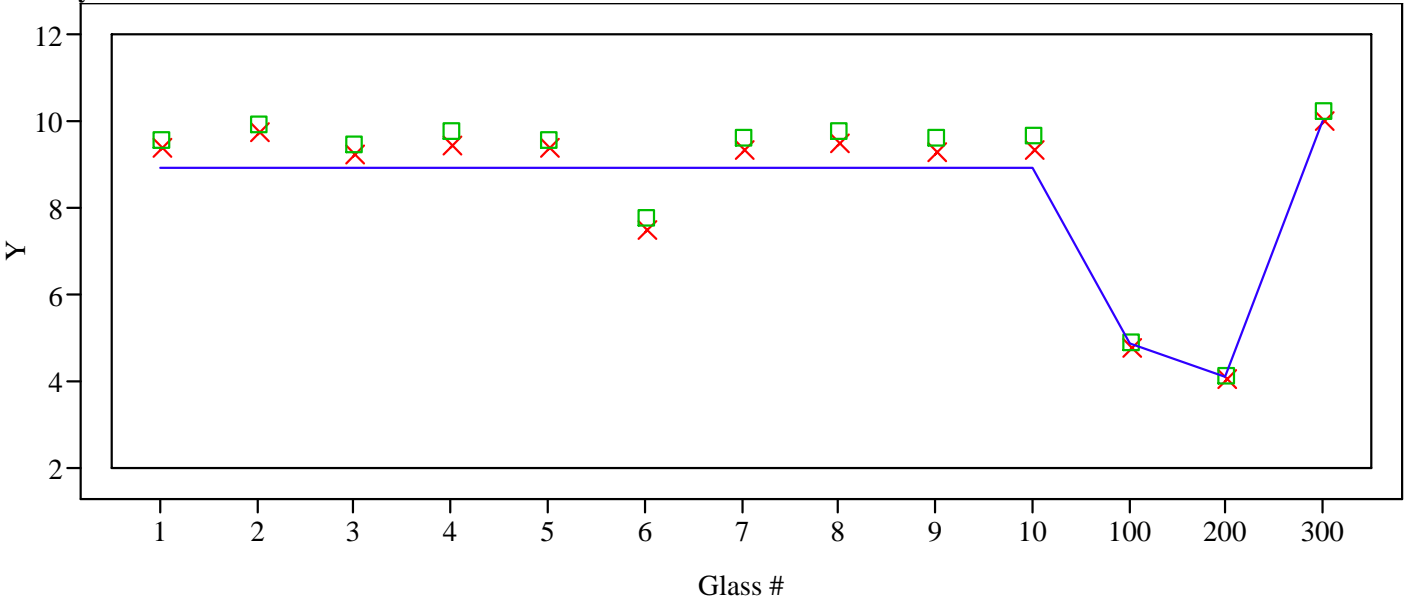

Overlay Plot Oxide=B2O3

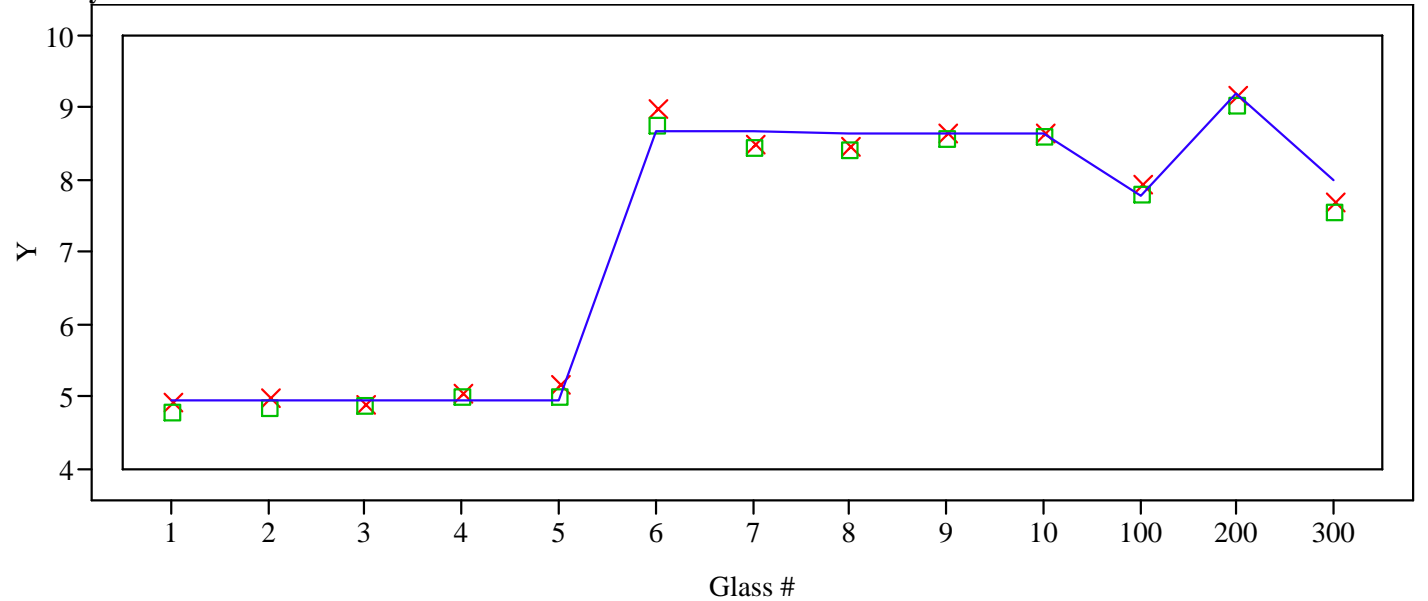

Overlay Plot Oxide=BaO

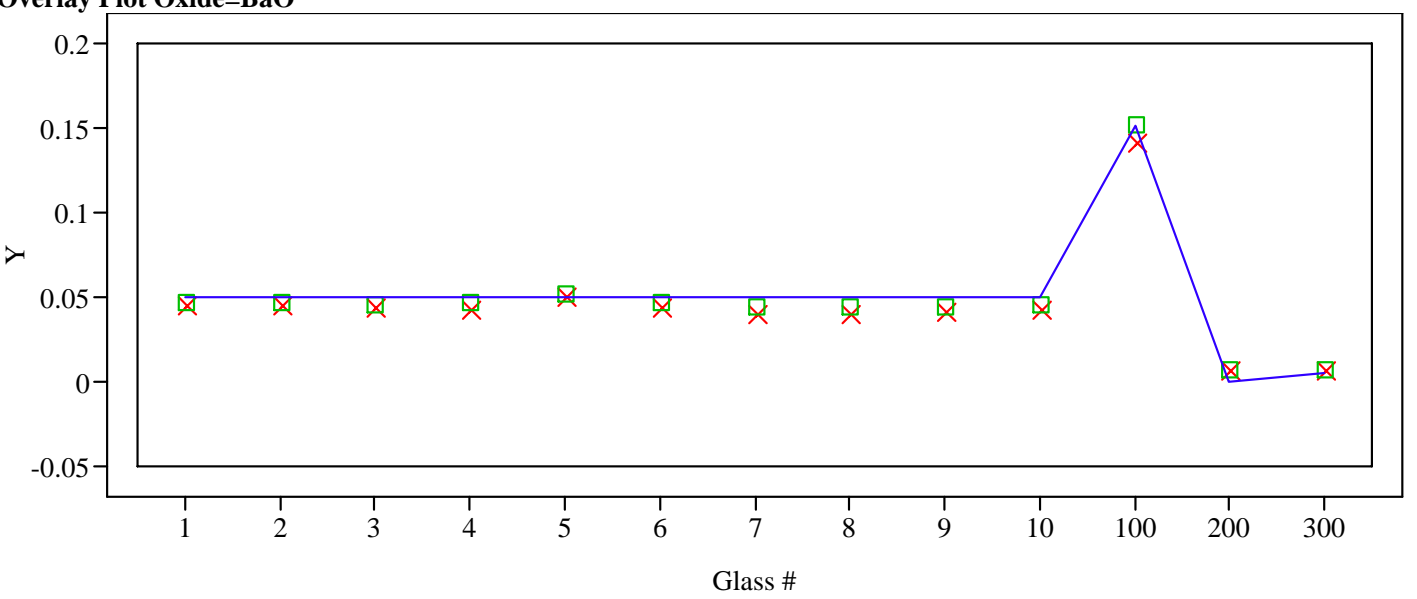

$\mathrm{Y} \times$ Measured (wt\%) $\quad$ Measured bc (wt\%) - Targeted (wt\%) 
Exhibit B7. Average Measured and Bias-Corrected (bc) Versus Targeted Compositions by Glass ID by Oxide (continued)

(100 - Batch 1; 200 - Ustd)

Overlay Plot Oxide $=\mathrm{CaO}$

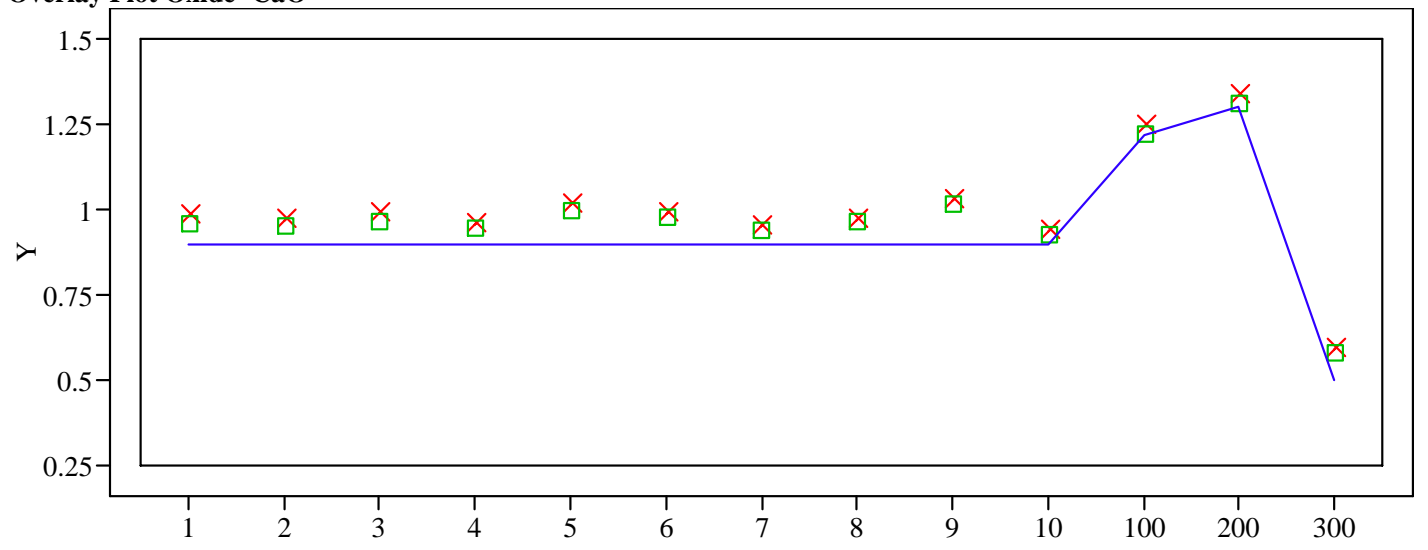

Glass \#

Overlay Plot Oxide=Ce2O3

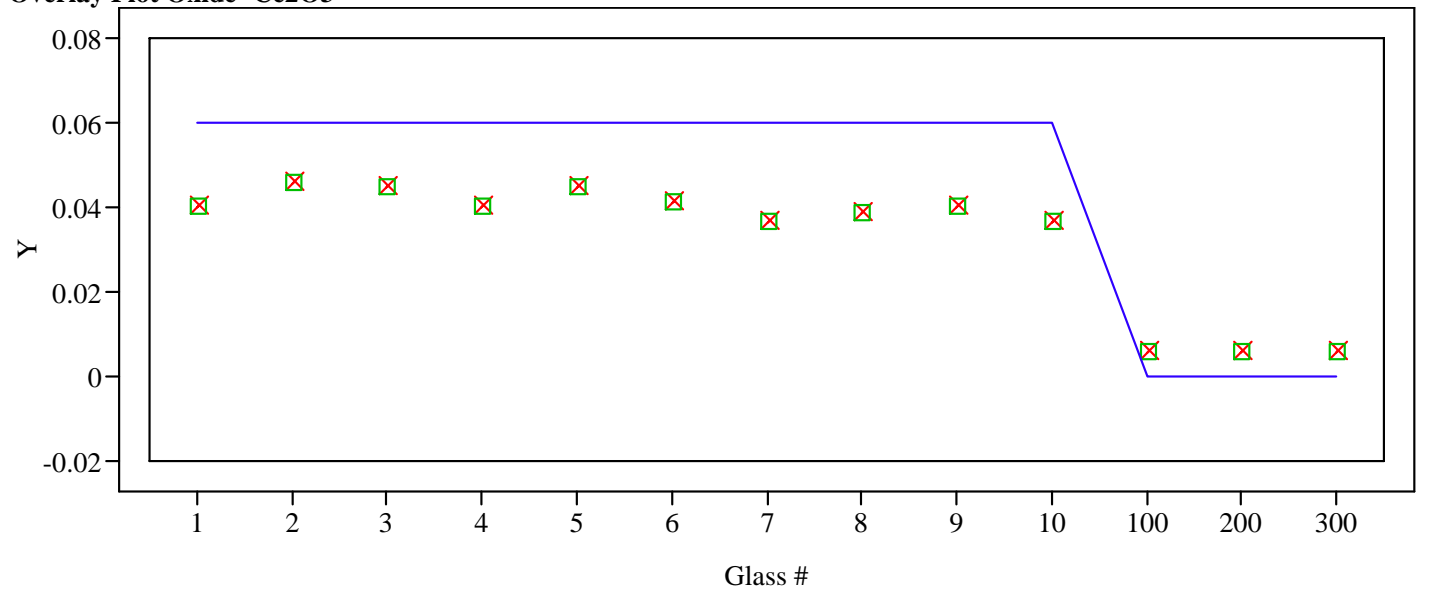

Overlay Plot Oxide $=\mathrm{Cr} 2 \mathrm{O} 3$

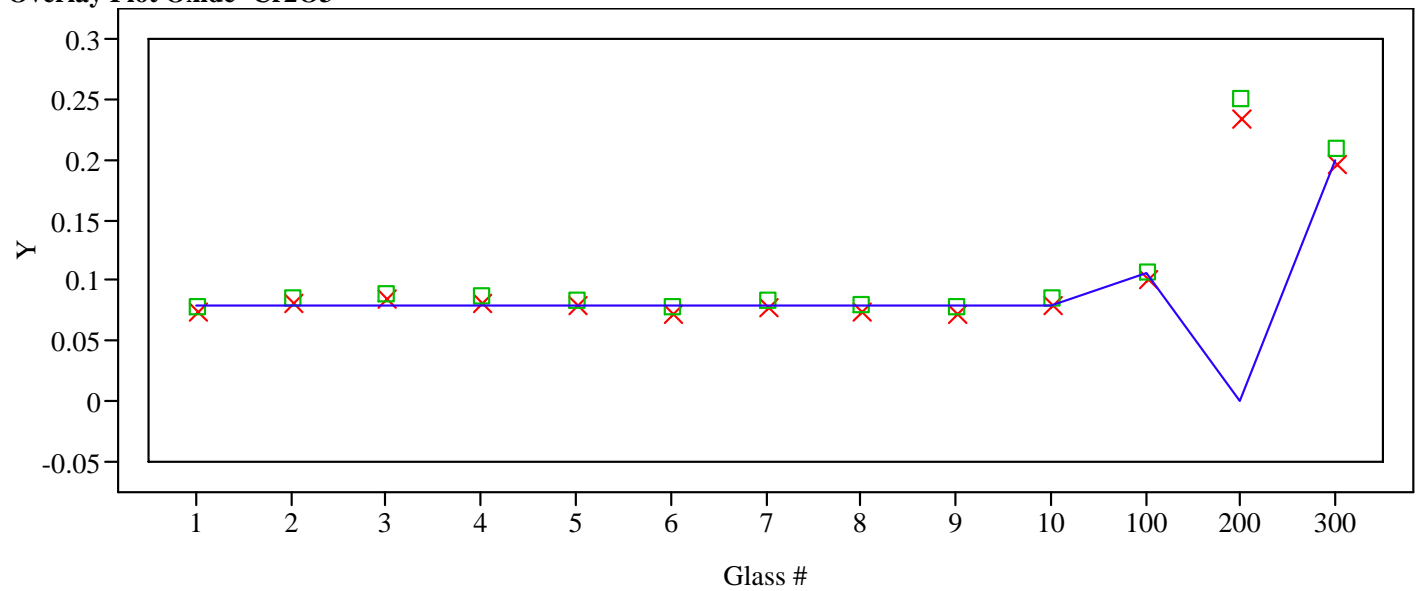

$\mathrm{Y} \times$ Measured (wt\%) $\quad$ Measured bc (wt\%) - Targeted (wt\%) 
Exhibit B7. Average Measured and Bias-Corrected (bc) Versus Targeted Compositions by Glass ID by Oxide (continued) (100 - Batch 1; 200 - Ustd)

Overlay Plot Oxide $=\mathrm{CuO}$

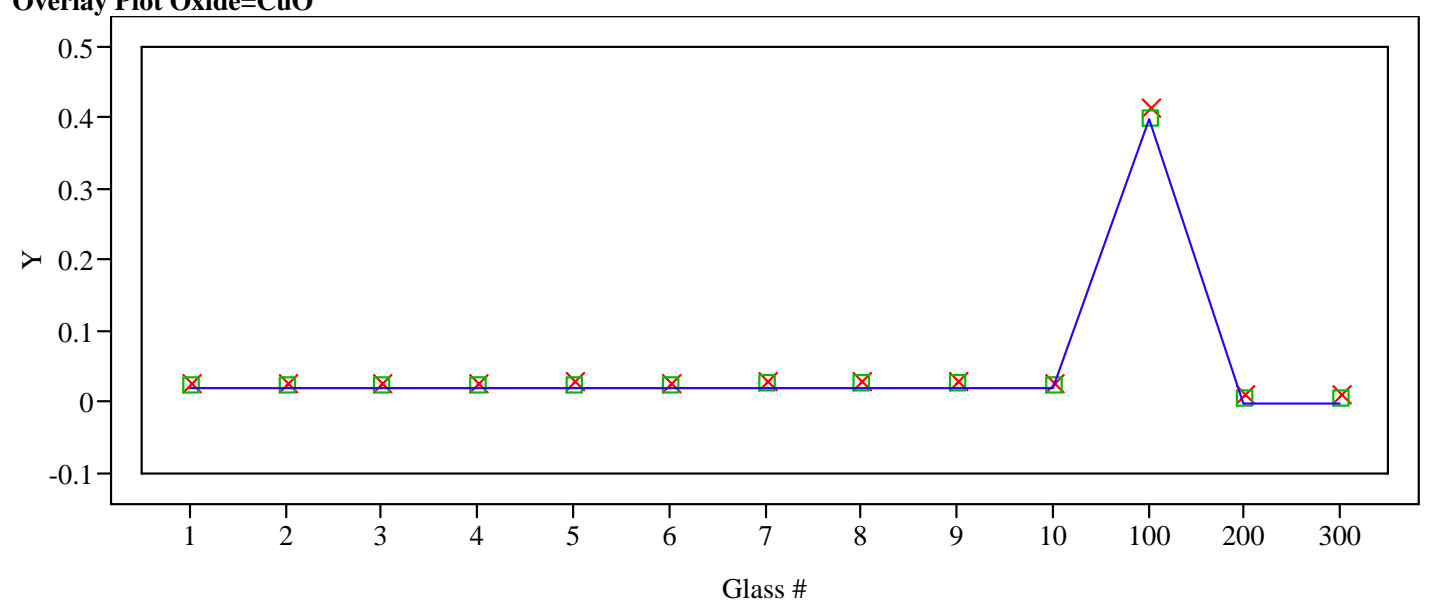

Overlay Plot Oxide=Fe2O3

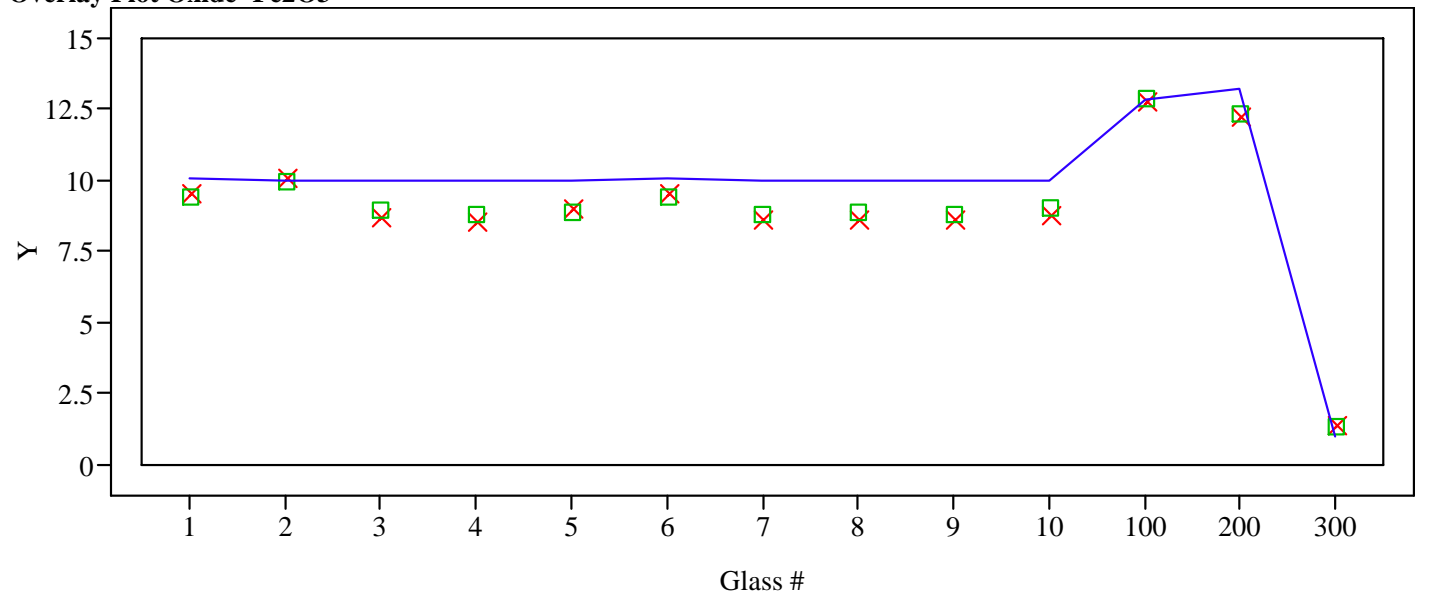

Overlay Plot Oxide $=$ K2O

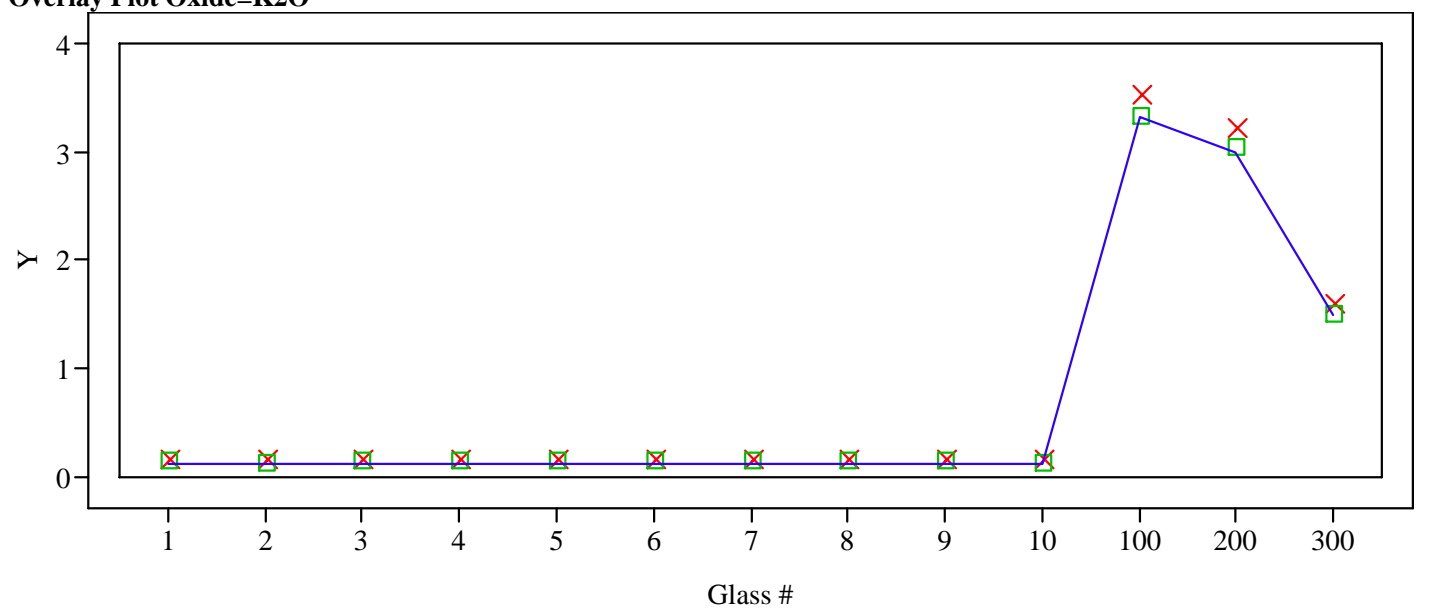

$\mathrm{Y} \times$ Measured (wt\%) $\square$ Measured bc (wt\%) —Targeted (wt\%) 
Exhibit B7. Average Measured and Bias-Corrected (bc) Versus Targeted Compositions by Glass ID by Oxide (continued) (100 - Batch 1; 200 - Ustd)

Overlay Plot Oxide $=\mathrm{La} 2 \mathrm{O} 3$

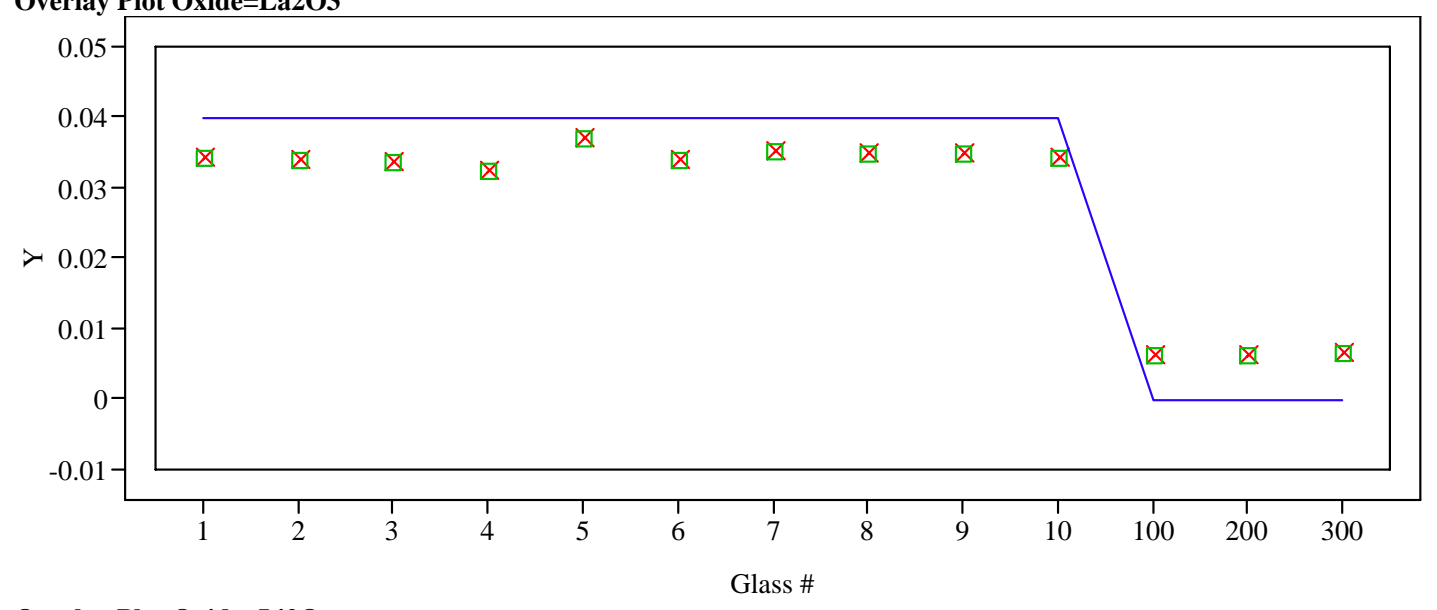

Overlay Plot Oxide $=$ Li2O

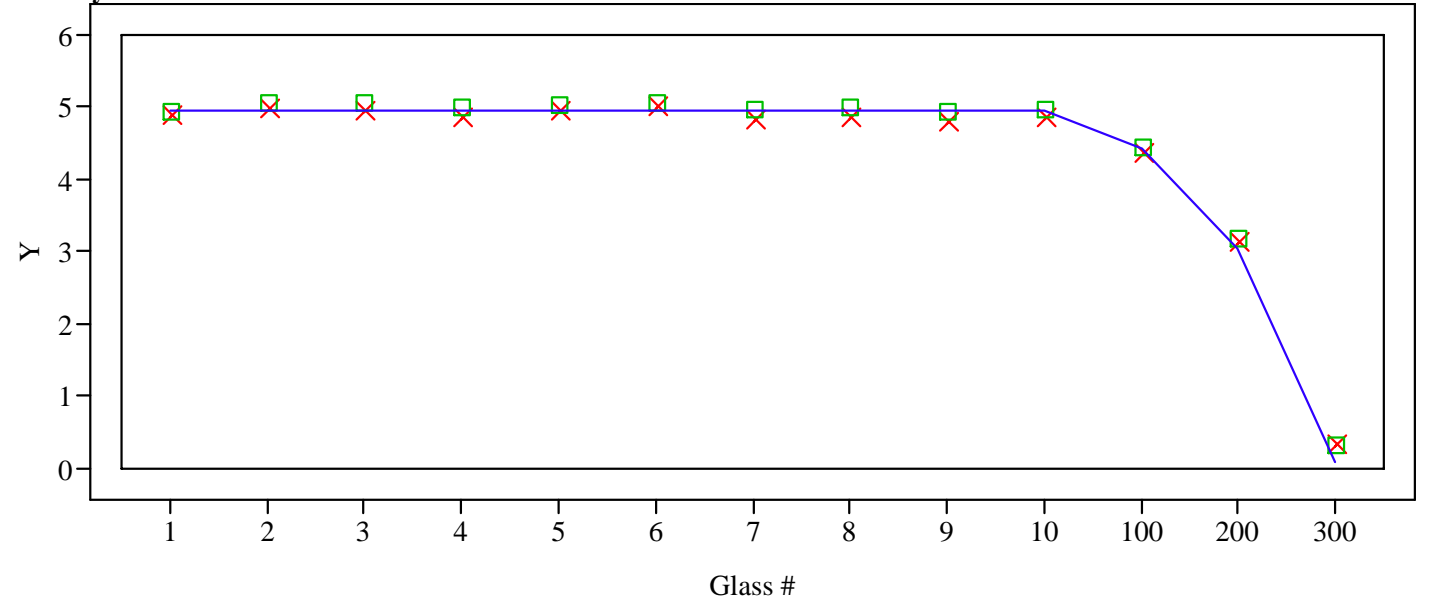

Overlay Plot Oxide $=$ MgO

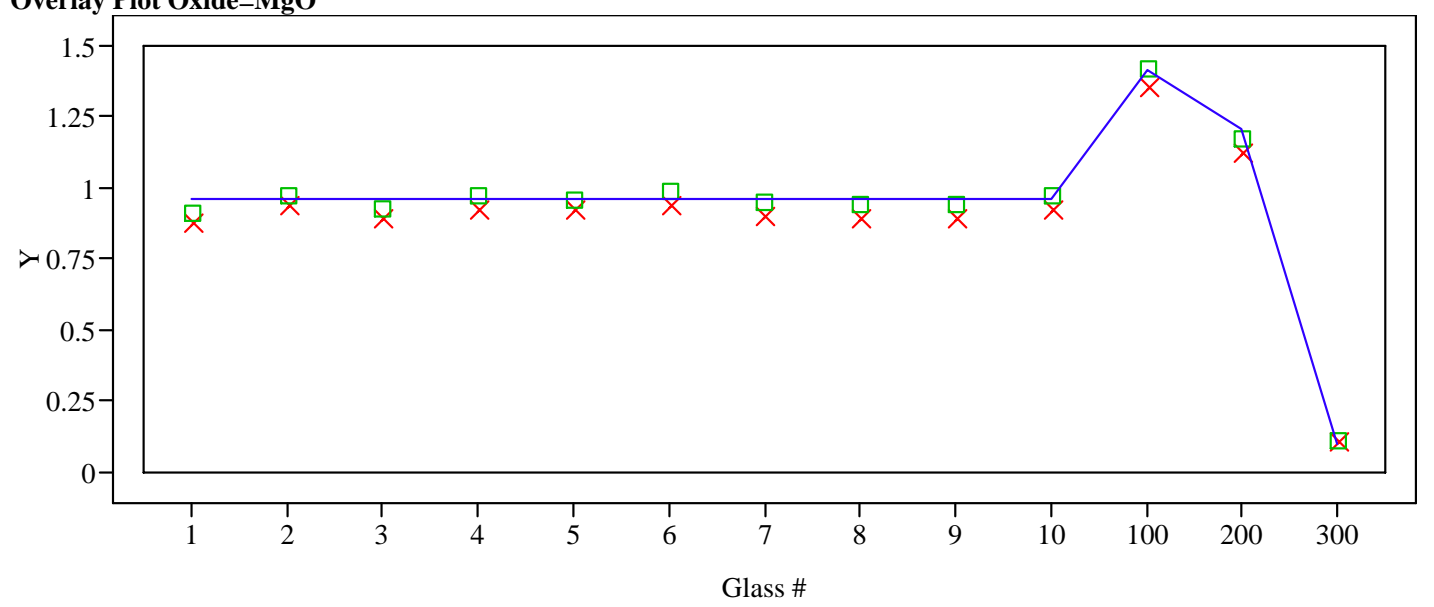

$\mathrm{Y} \times$ Measured (wt\%) प Measured bc (wt\%) —Targeted (wt\%) 
Exhibit B7. Average Measured and Bias-Corrected (bc) Versus Targeted Compositions by Glass ID by Oxide (continued) (100 - Batch 1; 200 - Ustd)

Overlay Plot Oxide $=\mathrm{MnO}$

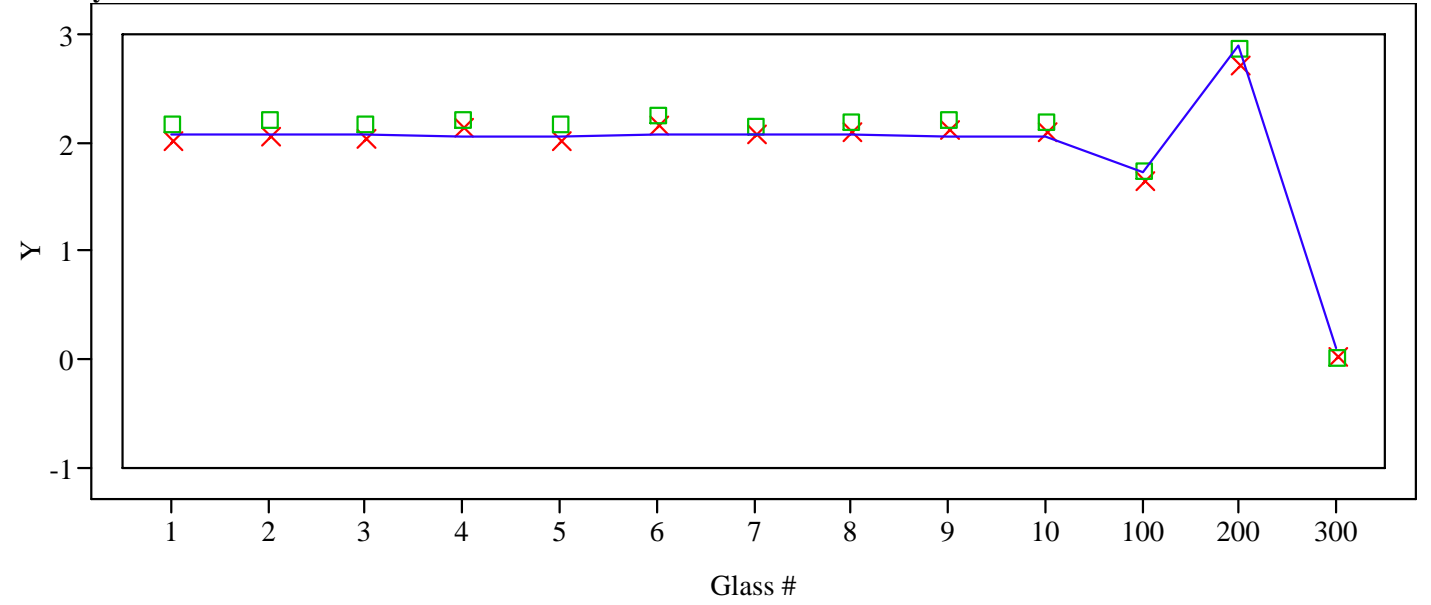

Overlay Plot Oxide $=\mathrm{Na} 2 \mathrm{O}$

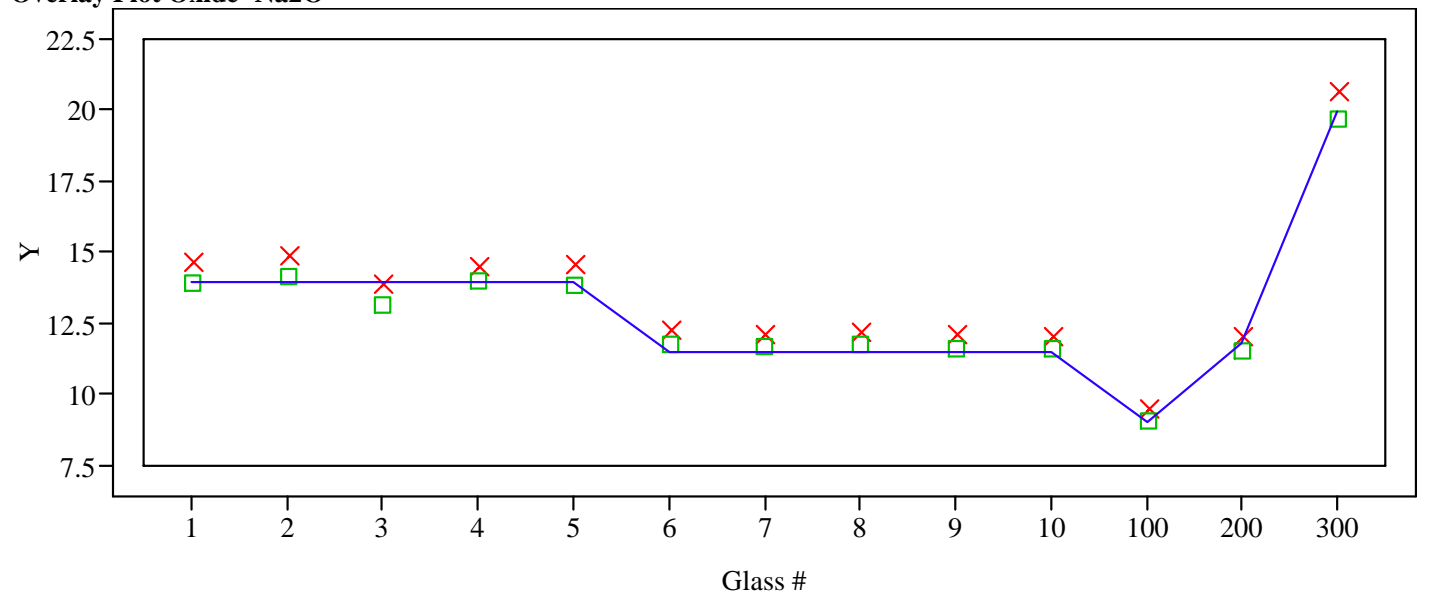

Overlay Plot Oxide $=\mathrm{NiO}$

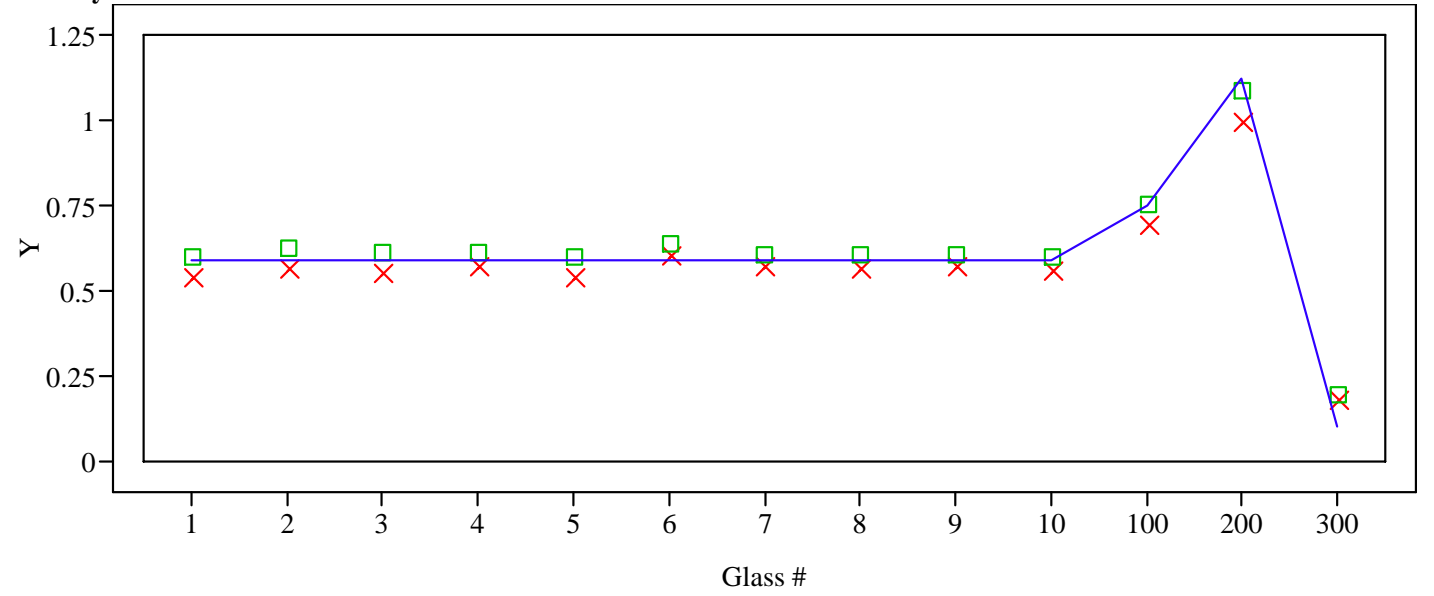

$\mathrm{Y} \times$ Measured (wt\%) $\square$ Measured bc (wt\%) - Targeted (wt\%) 
Exhibit B7. Average Measured and Bias-Corrected (bc) Versus Targeted Compositions by Glass ID by Oxide (continued)

(100 - Batch 1; 200 - Ustd)

Overlay Plot Oxide $=\mathbf{P b O}$

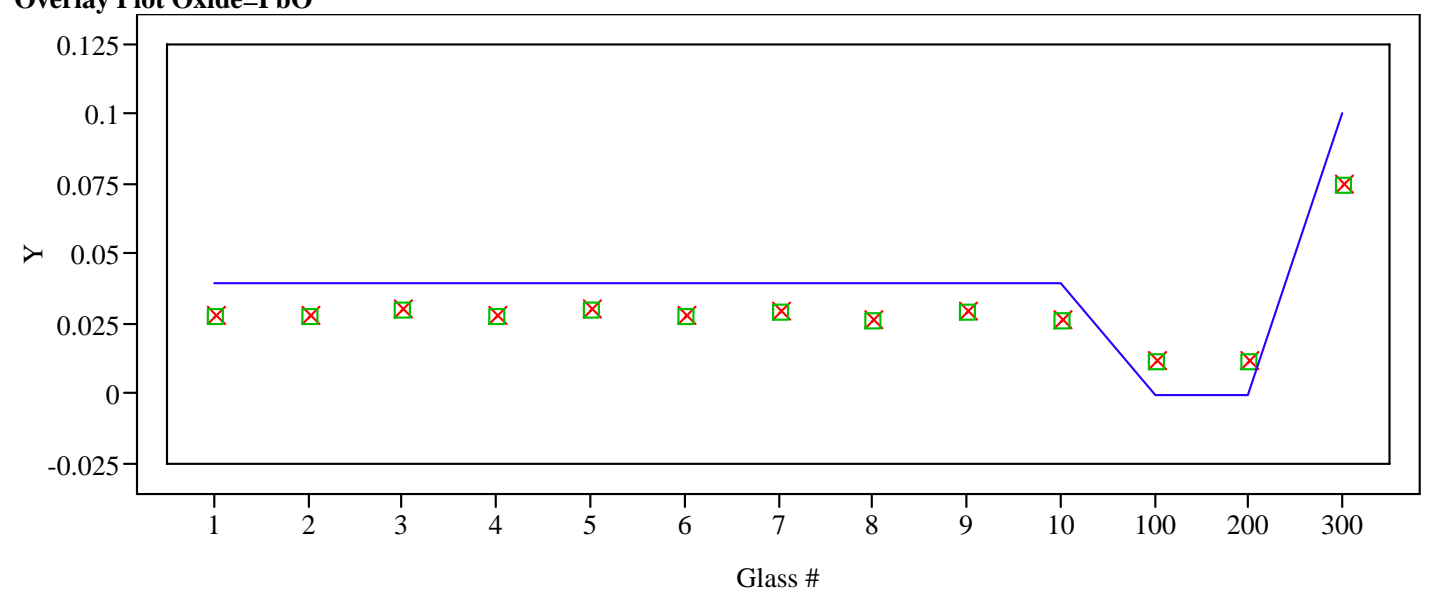

Overlay Plot Oxide $=\mathrm{SiO} 2$

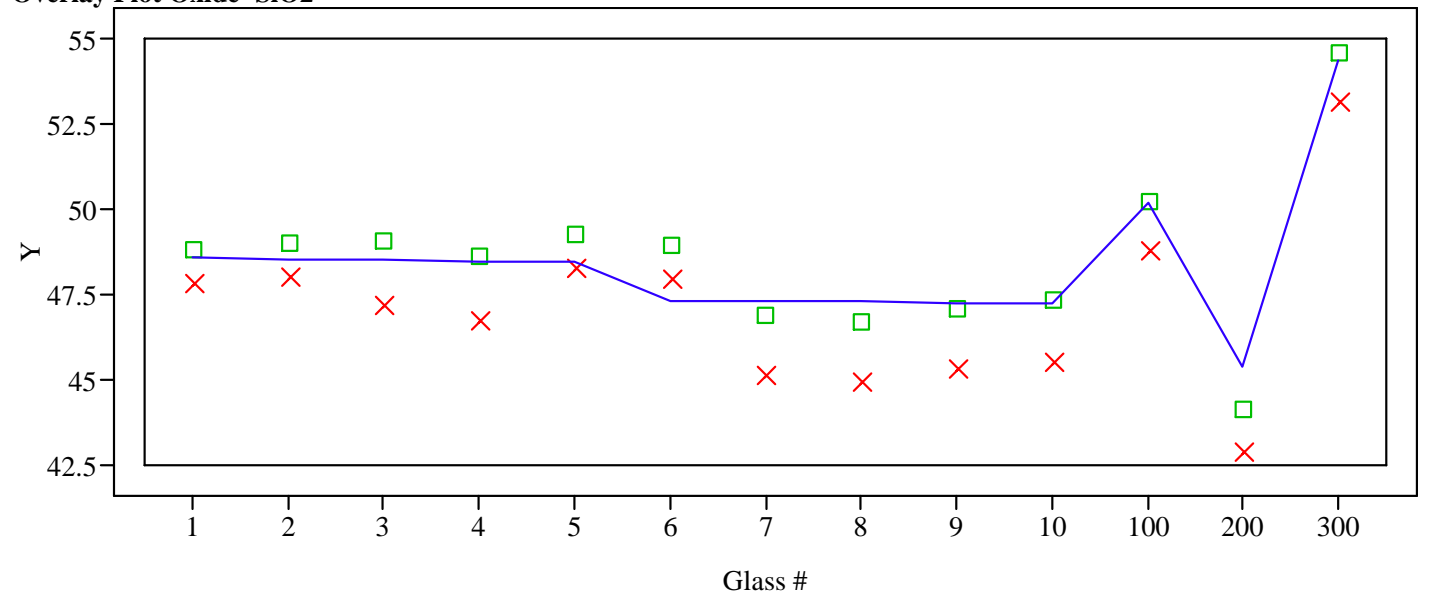

Overlay Plot Oxide=SO4

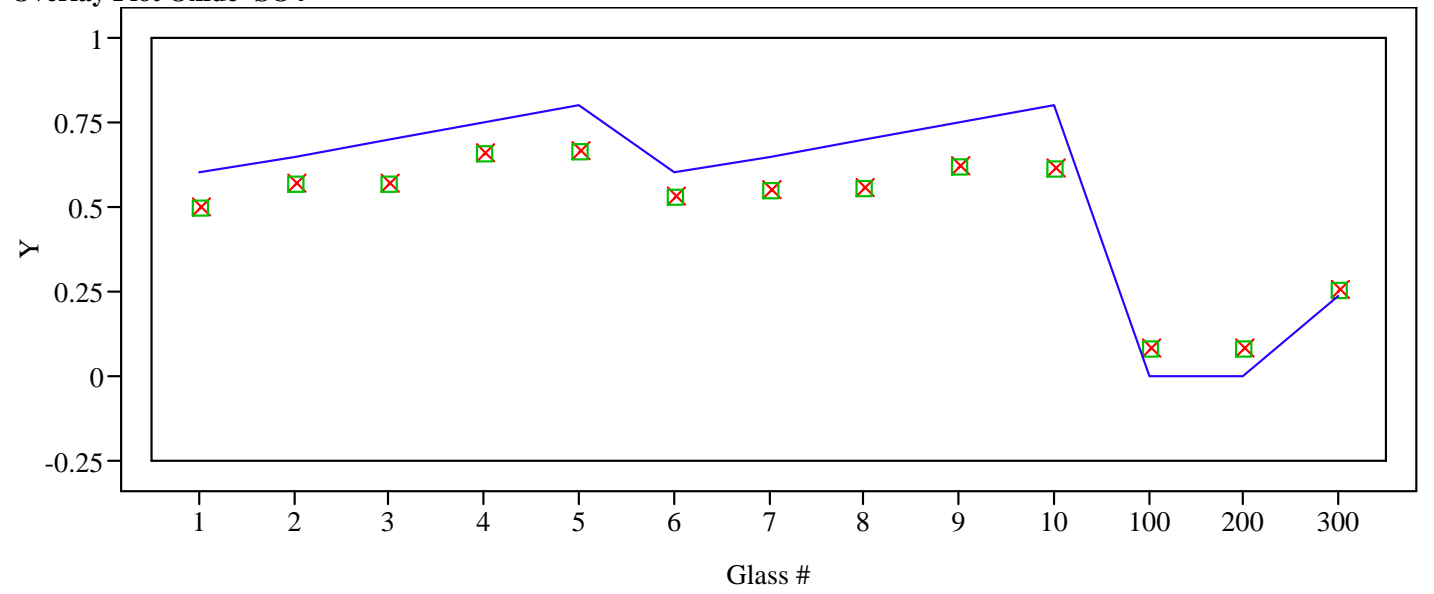

$\mathrm{Y} \times$ Measured (wt\%) $\quad \square$ Measured bc (wt\%) - Targeted (wt\%) 
Exhibit B7. Average Measured and Bias-Corrected (bc) Versus Targeted Compositions by Glass ID by Oxide (continued) (100 - Batch 1; 200 - Ustd)

Overlay Plot Oxide $=$ ThO2

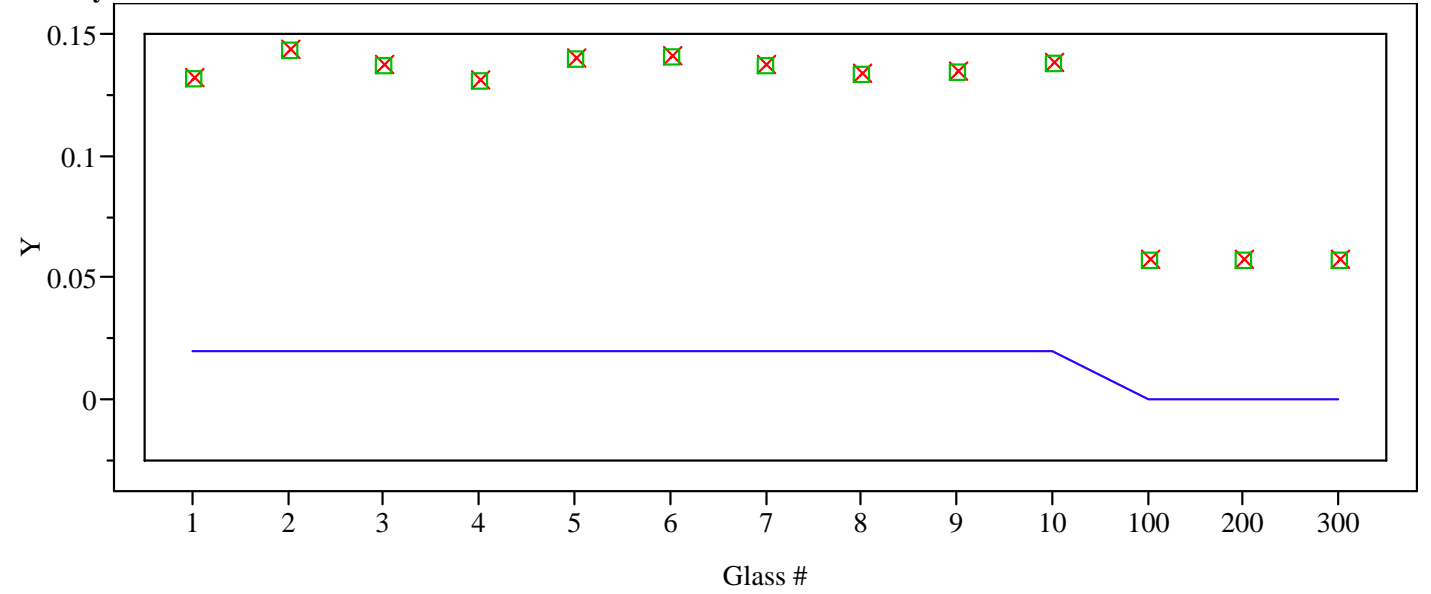

Overlay Plot Oxide=TiO2

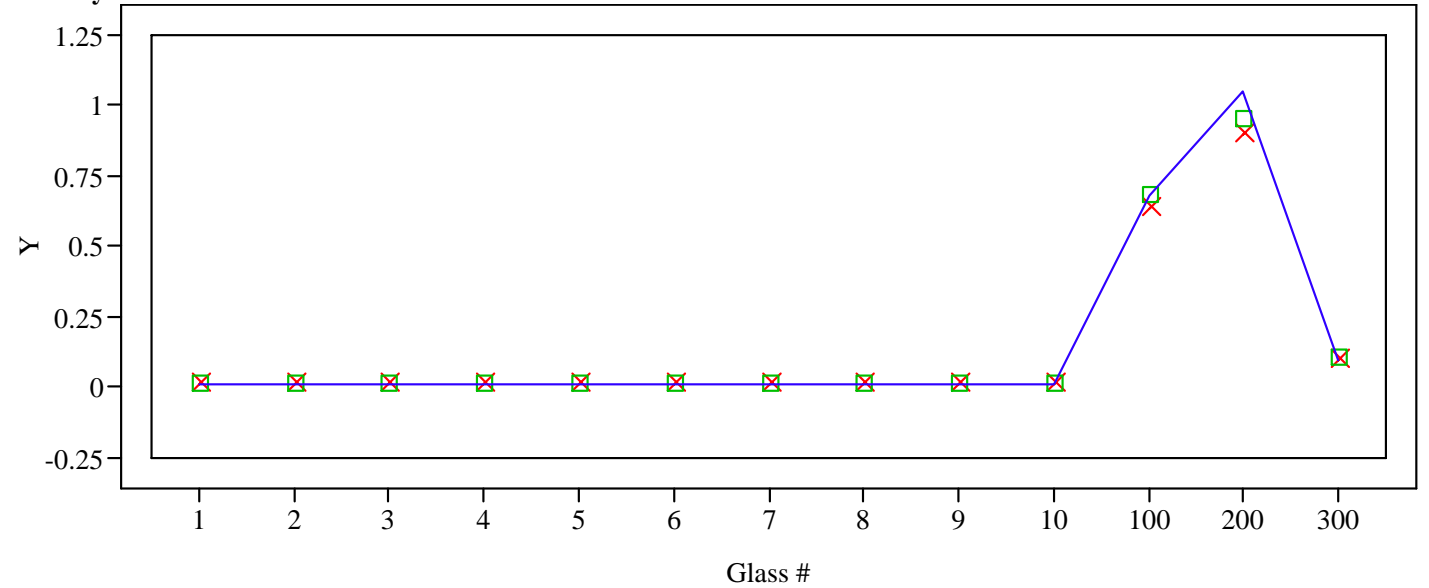

Overlay Plot Oxide $=$ U3O8

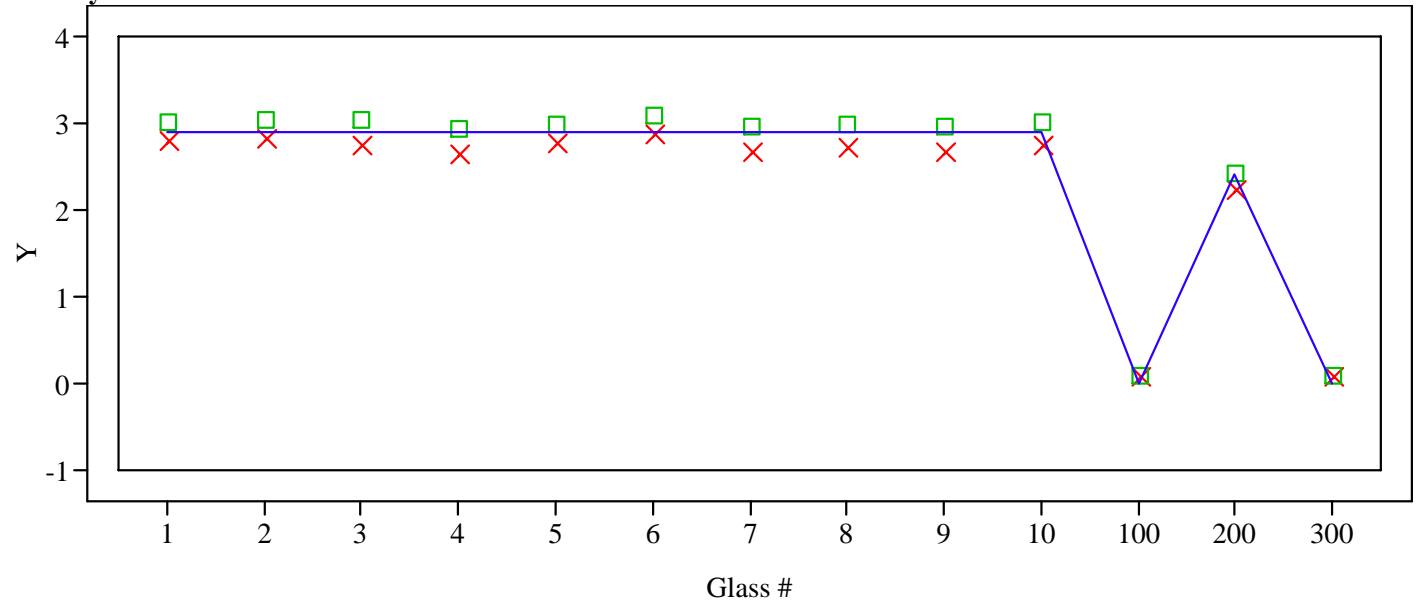

$\mathrm{Y} \times$ Measured (wt\%) $\quad \square$ Measured bc (wt\%) - Targeted (wt\%) 
Exhibit B7. Average Measured and Bias-Corrected (bc) Versus Targeted Compositions by Glass ID by Oxide (continued)

(100 - Batch 1; 200 - Ustd)

Overlay Plot Oxide $=\mathrm{ZnO}$

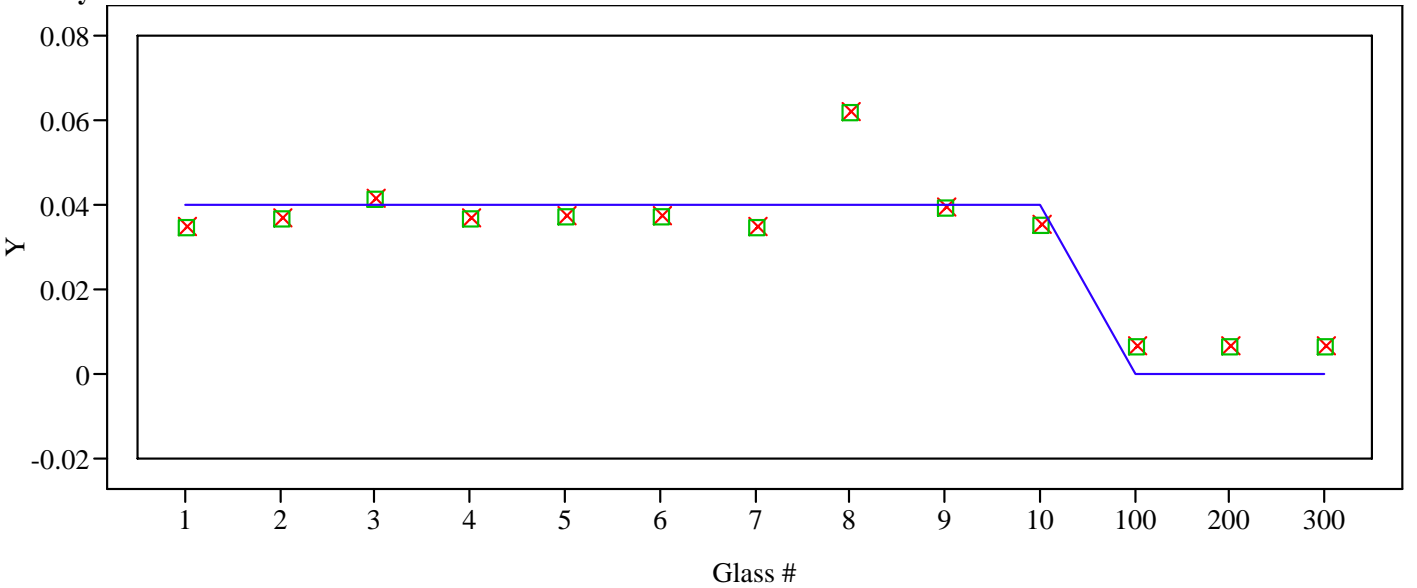

Overlay Plot Oxide $=\mathrm{ZrO} 2$

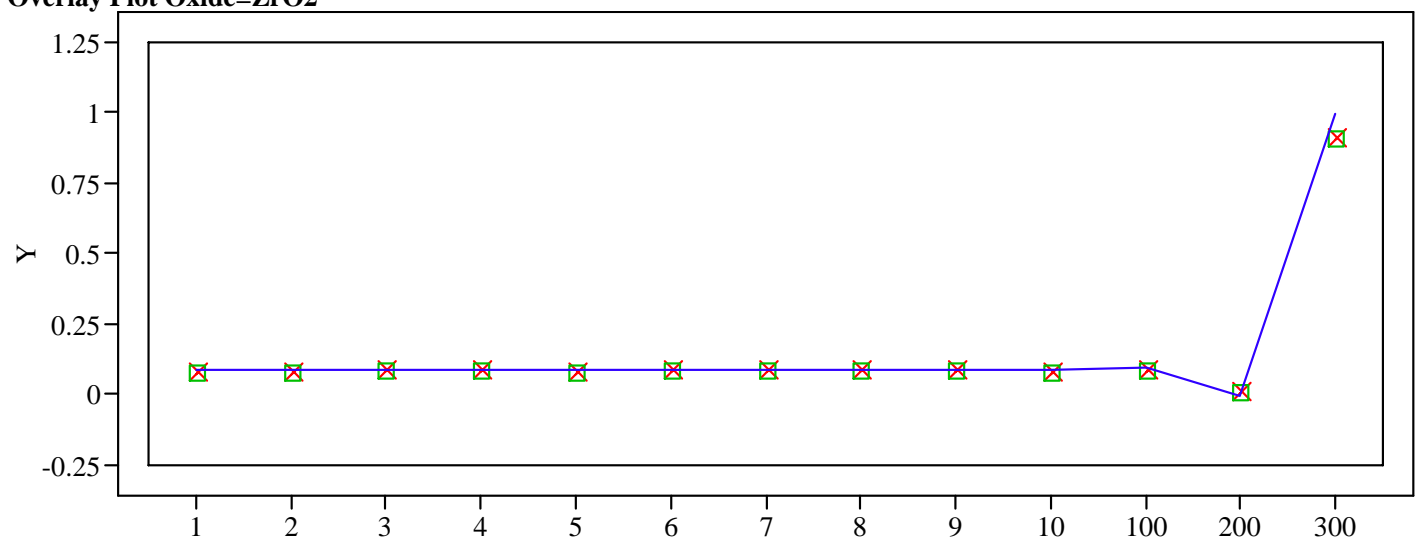

Glass \#

Overlay Plot Oxide= Sum of Oxides

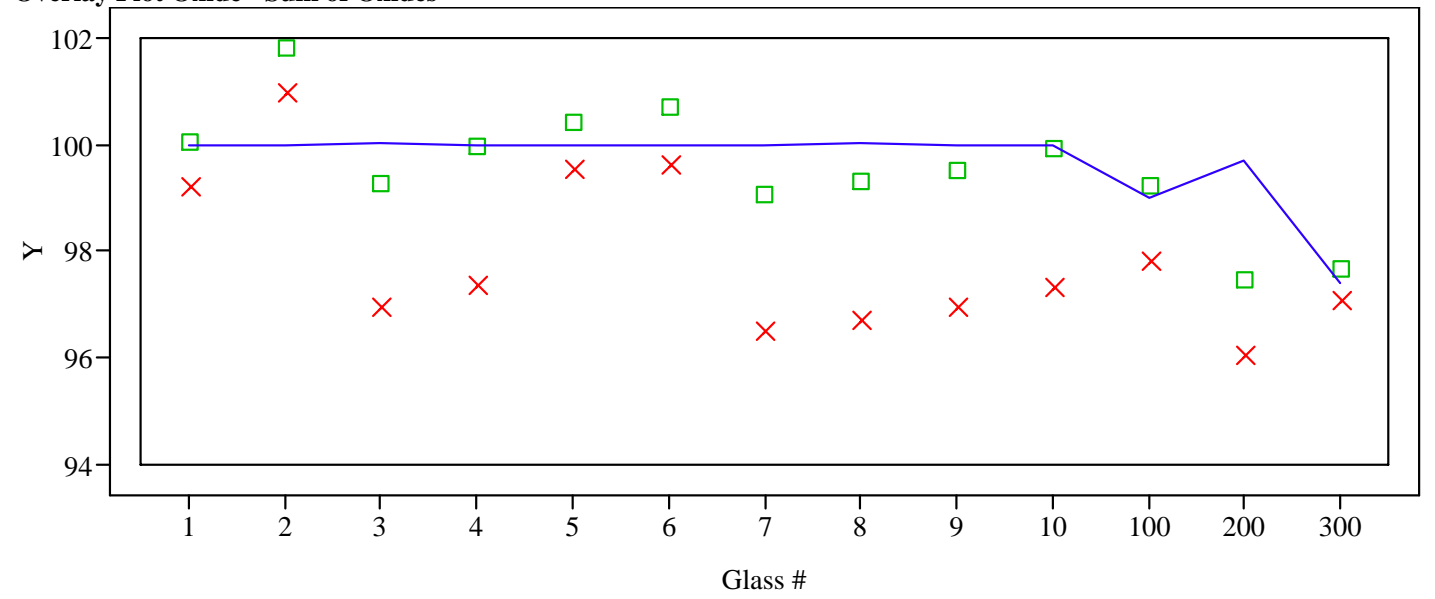

$\mathrm{Y} \times$ Measured (wt\%) $\quad$ Measured bc (wt\%) - Targeted (wt\%) 
WSRC-STI-2006-00038

Revision 0

This page intentionally left blank. 